UNIVERSIDADE DE SÃO PAULO

FACULDADE DE MEDICINA DE RIBEIRÃO PRETO

DEPARTAMENTO DE BIOLOGIA CELULAR E MOLECULAR E BIOAGENTES PATOGÊNICOS

PROGRAMA DE PÓS-GRADUAÇÃO EM BIOLOGIA CELULAR E MOLECULAR

\title{
Suscetibilidade de macrófagos alveolares murinos à infecção por Coxiella burnetii fase II in vitro
}

TALITA DUARTE FERNANDES

RIBEIRÃO PRETO - SP 


\title{
Suscetibilidade de macrófagos alveolares murinos à infecção por Coxiella burnetii fase II in vitro
}

\author{
Versão original
}

Tese apresentada à Faculdade de Medicina de Ribeirão Preto, Universidade de São Paulo, para obtenção do título de Doutor em Ciências.

Área de Concentração: Biologia Celular e Molecular

Orientador: Prof. Dr. Dario Simões Zamboni

RIBEIRÃO PRETO - SP 
Autorizo a reprodução e divulgação total ou parcial deste trabalho, por qualquer meio convencional ou eletrônico, para fins de estudo e pesquisa, desde que citada a fonte.

\section{FICHA CATALOGRÁFICA}

Preparada pela Biblioteca Central do Campus Administrativo de Ribeirão Preto / USP

FERNANDES, Talita Duarte

Suscetibilidade de macrófagos alveolares murinos à infecção por Coxiella burnetii fase II in vitro. Ribeirão Preto, 2018.

161 p. : il.; $30 \mathrm{~cm}$

Tese de Doutorado apresentada à Faculdade de Medicina de Ribeirão Preto/USP. Área de Concentração: Biologia Celular e Molecular

Orientador: ZAMBONI, Dario Simões.

1. Coxiella burnetii. 2. Macrófagos murinos. 3. Permissividade. 4. Polarização. 5. Modelo. 


\section{FOLHA DE APROVAÇÃO}

Nome: FERNANDES, Talita Duarte

Título: Suscetibilidade de macrófagos alveolares murinos à infecção por Coxiella burnetii fase II in vitro.

Tese apresentada à Faculdade de Medicina de Ribeirão Preto, Universidade de São Paulo, para obtenção do título de Doutor em Ciências.

Aprovada em:

\section{Banca Examinadora}

Prof. Dr. Instituição:

Julgamento: Assinatura:

Prof. Dr. Instituição:

Julgamento: Assinatura:

Prof. Dr. Instituição:

Julgamento: Assinatura:

Prof. Dr. Instituição:

Julgamento: Assinatura:

Prof. Dr. Instituição:

Julgamento: Assinatura: 
Aos meus pais, Miguel e Adriana, pela confiança inabalável em mim e pelo apoio constante em todos os meus projetos. 
"Science means constantly walking a tightrope between blind faith and curiosity; between expertise and creativity; between bias and openness; between experience and epiphany, between ambition and passion; and between arrogance and conviction - in short, between an old today and a new tomorrow". (Heinrich Rohrer) 


\section{AGRADECIMENTOS}

Aos meus pais, Miguel e Adriana, pelo amor incondicional e pelo apoio em todas as etapas da minha vida. Por sempre estarem ao meu lado, me incentivando e torcendo pelo meu sucesso em tudo aquilo que eu me atrevo a fazer. Obrigada por serem o porto seguro de todas as minhas jornadas! Ao meu irmão, Tiago, pelo convívio diário e cada vez mais próximo, por aguentar o meu humor peculiar e por estar ao meu lado o tempo todo, incluindo as várias madrugadas de trabalho. Vocês três são a minha base e a minha vida. Amo vocês!

A todos os meus familiares, minhas avós amadas, meus tios e tias, primos e primas... Pelos encontros em família, pelas disputas de jogos de tabuleiro, pelos churrascos e almoços de domingo e pela presença constante em minha vida. Obrigada por sempre acreditarem e torcerem por mim!

Ao Professor Dario Simões Zamboni, por ter acreditado em mim e por ter aceitado continuar esse processo de orientação, agora durante o doutorado. Obrigada por todo o apoio, desde a época da iniciação científica, e por demonstrar sempre que fazer ciência de qualidade é um desafio grande, porém extremamente recompensador. Sou grata pela confiança que depositou em mim durante essa trajetória, especialmente durante esse período de mudanças que vivi nos últimos tempos. Obrigada por ter contribuído de forma imprescindível para minha formação enquanto cientista e pesquisadora.

À Prof $f^{a}$ Hayley Newton (University of Melbourne at the Peter Doherty Institute for Infection and Immunity, Austrália), pela colaboração com o meu projeto, através de ótimas discussões científicas e por ter gentilmente cedido a Coxiella burnetii expressando mCherry, que foi fundamental para o desenvolvimento do meu artigo. Muito obrigada!

Aos membros da banca examinadora, por aceitarem meu convite e por se disponibilizarem para avaliação deste trabalho.

Aos colegas do Laboratório de Patogenicidade Microbiana e Imunidade Inata, tanto aqueles que passaram pelo laboratório e seguiram novos caminhos quanto aqueles que ainda estão presentes, meu muito obrigado por serem a melhor equipe com a qual alguém poderia desejar trabalhar. Obrigada por sempre estarem presentes e dispostos a ajudar quando precisei! Vocês tornaram esse processo muito mais divertido.

À Maira, nossa técnica querida, por toda a ajuda durante todos esses anos! Obrigada por sua dedicação ao Laboratório e por sempre contribuir para fazer tudo funcionar direitinho. Nossa vida seria muito mais complicada sem você! Agradeço ainda à Victória e Letícia, ajudarem a manter o laboratório organizado e tornar nosso trabalho muito mais fácil. 
Um agradecimento especial ao Djalma, Lili e Ju Ribeiro, não só pelos anos de convivência no laboratório, mas também pelo auxílio fundamental na produção do meu artigo. Suas contribuições foram essenciais para o sucesso da publicação. À Lari, que esteve comigo durante toda a minha iniciação científica e me ensinou a amar e respeitar essa bactéria incrível que é a Coxiella, muito obrigada por ter sido meu modelo de cientista logo que entrei nesse mundo de pesquisas. Tenho muito orgulho de ter o seu nome no meu artigo e tenho orgulho de poder dizer que fui sua "cria".

À Cati, Nati e Alexandre, obrigada por serem alguns dos melhores amigos que eu fiz no laboratório! Obrigada por todas as risadas, todo o apoio, toda a ajuda e toda a cumplicidade durante todos esses anos. A rotina pesada ficava muito mais fácil com vocês, e sentirei muita falta de todos! À Dani, minha amiga amada, muito obrigada por tudo que você faz e fez por mim dentro e fora do laboratório. Obrigada pela amizade, pelas viagens, pelas conversas, pelos treinos, por estar sempre por perto para me ouvir quando precisei, e principalmente por ser sempre sincera e falar aquelas verdades que eu posso não querer ouvir, mas que sei que são pro meu bem. Obrigada por muitas vezes acreditar em mim mais do que eu mesma, por me incentivar e por mostrar que eu capaz. Quando eu crescer, quero ser igual você!

Aos funcionários do biotério, pela paciência e pelo cuidado com os animais, fundamentais para realização desse trabalho. Um agradecimento especial ao Rubilan, que além de tudo sempre arrumava um tempo pra comentar comigo as últimas impressões sobre as partidas de futebol americano. À Maria Helena, pelo cuidado e ajuda no preparo dos materiais. À Tuca, Roberta e José pelo auxílio com as microscopias.

À Gabriela, secretária do Programa de Pós-graduação, pela paciência infinita e por sempre me atender com um sorriso no rosto toda vez que eu chegava desesperada com dúvidas sobre alguma coisa. Obrigada por sempre ser tão prestativa e por sempre conseguir me acalmar, Gabi!

A todos os funcionários, docentes e colegas do Programa de Pós Graduação em Biologia Celular e Molecular da FMRP e do Departamento de Biologia Celular e Molecular e Bioagentes Patogênicos, por contribuírem para criação de um espaço estimulante para discussão de ciência e por ajudrem no meu crescimento pessoal e profissional durante todos esses anos.

Às amizades de longa data, que estão ao meu lado em todos os momentos importantes e que fazem a minha vida mais feliz: Bia, Lo, Dani, Bá, Lê e Bru. Obrigada por serem as melhores amigas que alguém poderia ter. Obrigada pelos momentos de descontração, pelo 
apoio mútuo, pelo carinho de sempre e por serem aquelas com quem eu sei que sempre posso contar pra tudo que precisar. Amo vocês, meninas! À minha querida família francana, em especial à Marizinha e Cinthia, por esse amor que existe desde pequena e que ultrapassa a distância. Meu coração está sempre com vocês!

Aos colegas de trabalho que chegaram há não tanto tempo na minha vida, mas que compartilham as vitórias e as dificuldades dessa nova profissão que escolhi seguir, muito obrigada por participarem da construção dessa nova etapa da minha vida. Um agradecimento especial aos colegas peritos, Jesus, Bruna, André e Thatiany, à Marcella, auxiliar de autópsia mais fofa do mundo, e principalmente à Débora, minha médica legista preferida, que em tão pouco tempo de convivência se tornou uma das minhas melhores amigas. Amiguinha, obrigada por ser tão parecida comigo e por me entender tão bem! Obrigada por me incentivar nas horas difíceis, por sempre me fazer rir das coisas mais absurdas e por me permitir ser quem eu sou sem me julgar (muito).

Agradeço ainda à Universidade de São Paulo, por oferecer as condições necessárias para que eu pudesse crescer pessoal e profissionalmente, por meio de sua estrutura, funcionários e docentes. A todas as agências de fomento que auxiliam financeiramente o laboratório (CRID, INCTV, FAEPA, CNPq, FAPESP, TDR/WHO, PEW), meu muito obrigado pelo apoio essencial durante o desenvolvimento desse projeto. Um agradecimento especial à Coordenação de Aperfeiçoamento de Pessoal de Nível Superior (CAPES) pelo suporte financeiro concedido durante os anos iniciais do desenvolvimento desse trabalho (Código de Financiamento 001)..

Por fim, deixo ainda meu muito obrigado para aqueles que não mais estão por aqui, mas que sempre torceram por mim e que com certeza estariam orgulhosos: Vô Wilson, Vô Miguel, Tia Tê e Bisa. Saudades sempre... 


\section{RESUMO}

FERNANDES, Talita Duarte. Suscetibilidade de macrófagos alveolares murinos à infecção por Coxiella burnetii fase II in vitro. 2018. $161 \mathrm{f}$. Tese (Doutorado Direto em Biologia Celular e Molecular) - Faculdade de Medicina de Ribeirão Preto, Universidade de São Paulo, Ribeirão Preto, 2018.

Coxiella burnetii é a bactéria intracelular causadora da Febre Q, capaz de subverter funções celulares e evadir o reconhecimento do sistema imune da célula hospedeira permitindo o estabelecimento do seu nicho replicativo nas células-alvo: macrófagos e monócitos. É um patógeno altamente virulento, sendo necessário poucos organismos para desencadear a doença, e é considerado como um potencial agente de bioterrorismo da categoria B. Entre os danos econômicos causados por C. burnetii destaca-se a infecção de animais de gado, seu reservatório natural, pois causa aborto espontâneo dos filhotes e, consequentemente, prejuízo aos produtores. Seres humanos também adquirem a infecção, por inalação de partículas contaminadas. Hospedeiros imunocompetentes são capazes de restringir a infecção por $C$. burnetii apesar dos diversos mecanismos de evasão da resposta imune do hospedeiro, como interação com vias de sinalização celular e utilização de efetores bacterianos. No entanto, em hospedeiros não competentes a infecção pode evoluir para casos de Febre Q crônica e levá-los à morte. Modelos murinos são frequentemente utilizados para entender as interações patógeno-hospedeiro nas infecções por essa bactéria. A diferença na suscetibilidade de macrófagos de diferentes linhagens murinas e de diferentes tipos celulares à infecção por $C$. burnetii ainda é pouco conhecida. No entanto, sabe-se que C. burnetii fase II sucumbe a macrófagos derivados da medula óssea (BMDMs) de camundongos C57BL/6, enquanto células das linhagens $\mathrm{BALB} / \mathrm{c}$ e A/J são suscetíveis à infecção. Nesse contexto, considerando a relevância biomédica de C. burnetii, faz-se necessário a determinação de um modelo relevante para melhor compreender as relações patógeno-hospedeiro nas infecções por essa bactéria. Neste trabalho, caracterizamos um novo modelo de estudo com macrófagos primários que permite avaliar a infecção com C. burnetii fase II in vitro, além de elucidar os mecanismos relacionados à suscetibilidade das células à bactéria. Por meio de quantificação do DNA genômico bacteriano por qPCR verificamos que macrófagos alveolares (AMs) murinos são altamente suscetíveis à replicação da bactéria, mesmo no fundo gênico restritivo C57BL/6. Caracterizamos a replicação da bactéria em AMs por microscopia de fluorescência e microscopia eletrônica de transmissão e demonstramos que essa replicação ocorre dentro dos vacúolos parasitóforos típicos. Pela análise de expressão gênica por RT-PCR e 
fenotipagem de marcadores de superfície por FACS identificamos que a alta suscetibilidade dos AMs se deve a uma polarização dessas células para um padrão M2. Por fim, validamos a relevância desse modelo pela análise da suscetibilidade de AMs murinos deficientes para NOS2, IFN- $\gamma$ e IL-4 como prova de princípio. Verificamos que a suscetibilidade de AMs é comparável à de células Vero e células THP-1, modelos celulares imortalizados descritos como altamente suscetíveis à replicação de $C$. burnetii, e que AMs podem ser utilizados para estudos utilizando células derivadas de camundongos com fundo gênico C57BL/6. Dessa forma, nosso trabalho caracterizou os AMs murinos como um relevante modelo celular primário altamente suscetível para o estudo das interações patógeno-hospedeiro frente à infecção in vitro por C. burnetii fase II, além de elucidar os mecanismos por trás dessa suscetiblidade.

Palavras-chave: Coxiella burneti. Macrófagos murinos. Permissividade. Polarização. Modelo. 


\begin{abstract}
FERNANDES, Talita Duarte. Susceptibility of murine alveolar macrophages to infection by Coxiella burnetii phase II in vitro. 2018. $161 \mathrm{f}$. Tese (Doutorado Direto em Biologia Celular e Molecular) - Faculdade de Medicina de Ribeirão Preto, Universidade de São Paulo, Ribeirão Preto, 2018.
\end{abstract}

Coxiella burnetii is the intracellular bacterium that causes $\mathrm{Q}$ fever, capable of subverting cellular functions and evading recognition by the host cell immune system, thus allowing the establishment of its replicative niche in its the target cells: macrophages and monocytes. It'as a highly virulent pathogen, with few organisms being sufficient to cause the disease, and considered a potential class B bioterrorism agent. Among the economic damages caused by $C$. burnetii are infection of cattle animals, its natural reservoir, that leads to spontaneous abortion of the offspring and financial loss to the producers. Human beings also acquire the infection, through inhalation of contaminated air particles. Immunocompetent hosts are able to restrict infection by $C$. burnetii despite the several evasion mechanisms from the host immune system, which includes interaction with cell signaling pathways and utilization of bacterial effectors. However, in non-competent hosts the infection can evolve to chronic Q Fever and lead to death. Murine models are frequently used to understand the host-pathogen interactions during infections by this bacterium. The difference in the susceptibility among macrophages from different murine strains, as well as different cell types, still poorly known. However, it is known that $C$. burnetii phase II succumbs to bone-marrow derived macrophages (BMDMs) from $\mathrm{C} 57 \mathrm{BL} / 6$ mice, whereas cells from $\mathrm{BALB} / \mathrm{c}$ and $\mathrm{A} / \mathrm{J}$ strains are susceptible to infection. In this context, considering the biomedical relevance of $C$. burnetii, it's necessary to establish a relevant study model to better understand the host-pathogen relations in infections by $C$. burnetii. In this work, we characterized a new study model with primary macrophages to assess the infection by $C$. burnetii phase II in vitro and elucidated the mechanisms underlying the susceptibility to $C$. burnetii. By using qPCR for quantification of bacterial genomic DNA, we saw that murine alveolar macrophages (AMs) are highly susceptible to C. burnetii replication, even in the usually restrictive C57BL/6 backgound. We characterized the bacterium replication in murine AMs by florescence microscopy and transmission electron microscopy, showing that this replication occurred inside the typical C. burnetii-containing vacuole. We also identified, through the gene expression by RT-PCR and the phenotypic profile of surface markers by FACS, that the increased susceptibility of murine AMs were due to a polarization of these cells into a M2 profile. To finish, we validated the relevance of this 
model through the analysis of the susceptibility of murine AMs deficient to NOS2, IFN- $\gamma$ and IL-4 as a proof of principle. We verified that the susceptibility of AMs is comparable to Vero cells and THP-1 cells, immortalized cell models described as highly susceptible to C. burnetii replication, and that AMs can be used to studies using cells derived from mice with the C57BL/6 background. In this way, our work characterized murine AMs as a relevant primary cell model highly susceptible to studies among the host-pathogen interactions in infections with $C$. burnetii phase II in vitro, and we also elucidate the mechanisms underlying this susceptibility.

Keywords: Coxiella burnetii. Murine macrophages. Permissiveness. Polarization. Model. 


\section{LISTA DE FIGURAS}

Figura 1 - Representação do ciclo de vida bifásico de $C$.

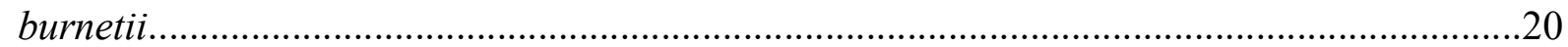

Figura 2 - Processo de desenvolvimento e maturação do vacúolo contendo $C$. burnetii. 25

Figura 3 - Representação do modelo de polarização de macrófagos com os estados comuns para humanos e camundongos. .32

Figura 4 - Representação dos modelos de plasticidade e ontogenia na determinação do estado de polarização dos macrófagos.

Figura 5 - Macrófagos murinos derivados de medula óssea da linhagem A/J são mais suscetíveis à multiplicação de C. burnetii fase II do que macrófagos murinos derivados de medula óssea da linhagem C57BL/6.

Figura 6 - Macrófagos alveolares murinos são permissivos à replicação de $C$. burnetii fase II.

Figura 7 - Localização intracelular de C. burnetii fase II em macrófagos alveolares murinos visualizada por microscopia confocal de fluorescência.

Figura 8 - Localização intracelular de C. burnetii fase II em macrófagos alveolares murinos visualizada por microscopia eletrônica de transmissão .56

Figura 9 - Macrófagos alveolares murinos exivem níveis mais elevados de expressão de genes relacionados com o padrão de polarização M2

Figura 10 - Macrófagos alveolares murinos exibem um fenótipo de polarização M2.

Figura 11 - Macrófagos alveolares murinos possibilitam a utilização de macrófagos deficientes no fundo gênico $\mathrm{C} 57 \mathrm{BL} / 6$ para avaliação da resposta immune inata contra $C$. burnetii fase II

Figura 12 - Macrófagos alveolares murinos são permissivos à replicação de $C$. burnetii fase II in vitro de forma semelhane às células Vero e células THP-1 


\section{LISTA DE ABREVIATURAS, SIGLAS, UNIDADES E SÍMBOLOS}

AM: Alveolar macrophage

Ank: Ankyrin

AKT/PKB: Protein kinase $B$

ANOVA: Análise de variância

BAL: Bronchoalveolar lavage

BCG: Bacillus Calmette Guerin

Bcl2: B-cell lymphoma 2

Beclin1: Bcl-2 interacting coiled-coil protein

BMDMs: Bone marrow-derived macrophages

BSA: Bovine serum albumin

C. burnetii: Coxiella burnetii

Caspase: Cysteine-dependent aspartate-specific protease

CCV: Coxiella-containing vacuole

CD206: receptor de manose

CD369: dectina-1

CETEA: Comitê de Ética e Experimentação Animal

$\mathrm{CO}_{2}$ : Dióxido de carbono

COX2: Cyclooxygenase 2

CR3: Complement receptor 3

CT: Cycle Threshold

DAMPs: Damage-associated molecular pattern 
DAPI: 4',6'-diamindino-2-phenylindole dilactate

DIC: Differential interference contrast

DMEM: Dulbecco's modified Eagle's medium

DNA: Deoxyribonucleic acid

cDNA: Complementary DNA

Dot: Defective organelle trafficking

EDTA: Ethylene Diamine Tetracetic Acid

EEA1: Early endosome antigen 1

Erk1: Extracellular signal-Regulated Kinase 1

Erk2: Extracellular signal-Regulated Kinase 2

FACS: Fluorescence-activated cell sorting

FIZZ1: Found in inflammatory zone 1

FSC: Forward scatter

FWD: Primer forward

g: Grama

Gy: Gray

h: Horas

IcaA: Inhibition of Caspase-1 Activation

Icm: Intracellular multiplication

IFN: Interferon

IL: Interleukin

IL-1R: Interleukin-1 receptor

iNOS: Inducible nitric oxide synthase 
IRS-PCR: Infrequent restriction site polymerase chain reaction

kHZ: quilo-Hertz

LAMP-1: Lysosomal-membrane-associated glicoprotein -1

LAMP-2: Lysosomal-membrane-associated glicoprotein -2

LC3: Light-chain 3

LCCM: L929 Cell Conditioned Medium

LCV: Large cell variant

log: logaritmo na base 10

LPS: Lipopolysaccharide

LRV: Large replicative vacuole

M: molar

MAMPs: Microbe-associated molecular patterns

MAPK: Mitogen Activated Protein Kinases

MOI: Multiplicity of Infection

M-CSF: Macrophage colony-stimulating factor

mg: Miligrama

MHC: Major histocompatibility complex

min: minutos

MLVA: Multiple locus VNTR analyses

mL: mililitros

mM: Milimolar

MOI: Multiplicity of infection

mRNA: RNA mensageiro 
MST: Multispacer sequence typing

NADPH: Nicotinamide adenine dinucleotide phosphate

NF-кB: Nuclear Factor Kappa B

ng: Nanograma

NLR: Nucleotide-binding domain leucine-rich repeat-containing protein

NLRP: NLR family, Pyrin domain-containing

nm: Nanômetro

NMI: Nine Mile I

NMII: Nine Mile II

NO: Nitric oxide

NOS2: Nitric oxide synthase 2

PARP: Poly ADP-ribose processing

PBS: Phosphate-Buffered Saline

PCR: Polimerase Chain Reaction

PFA: paraformaldehyde

PMA: Phorbol 12-myristate 13-acetate

Pro-IL: Pro-interleukin

PRRs: Pattern Recognition Receptors

qPCR: Quantitative Polimerase Chain Reaction

REV: Primer reverse

RFLP: Restriction fragments length polymorphisms

RGD: arginine-glycine-aspartic acid domain

Rho: Ras homologous 
RIF: rifampicina

RNA: Ribonucleic acid

RNS: Reactive nitrogen species

ROS: Reactive Oxigen Species

rpm: rotação por minuto

RPMI: Roswell Park Memorial Institute medium

rRNA: RNA ribossômico

RT-PCR: Reverse transcriptase Polimerase Chain Reaction

SBF: Soro Bovino Fetal

SCV: Small cell variant

SNARE: Soluble NSF-attachment receptor

SNP: Single nucleotide polymorphisms

SSC: Side scatter

STAT: Signal Transducer and Activator of Transcription

TGF: Tumor growth factor

TH1: Type 1 Thelper

TH2: Type 2 Thelper

THP-1: Tohoku Hospital Pediatrics-1

TLR: Toll-Like Receptor

TNF: Tumor Necrosis Factor

T4SS: Type IV Secretion System

WT: wild-type

YM1/Chil3: chitinase-like protein 3 
$\mu g:$ Micrograma

$\boldsymbol{\mu L}:$ Microlitros

$\boldsymbol{\mu M}$ : Micromolar

$\mu \mathrm{m}$ : Micrômetro

${ }^{\circ} \mathbf{C}$ : Graus Celsius 


\section{SUMÁRIO}

1. INTRODUÇÃ̃O................................................................. 14

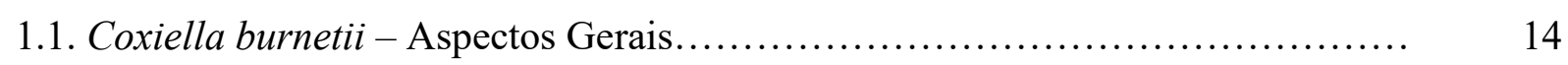

1.2. O vaúcolo parasitóforo de Coxiella burnetii e sua interação com vias do hospedeiro.......................................................... 21

1.3. Ativação e subversão da resposta imune por Coxiella burnetii................... 25

1.4. Polarização de macrófagos e monócitos em resposta à Coxiella burnetii.......... 30

1.5. Modelos de estudo das interações patógeno-hospedeiro com infecção por Coxiella

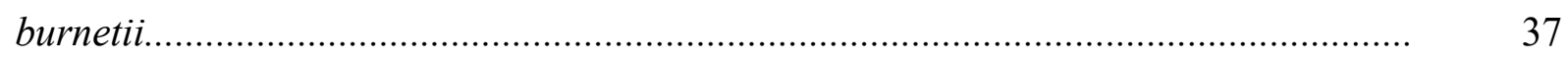

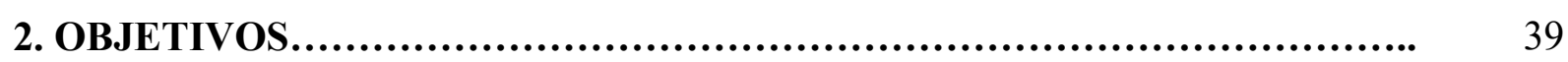

2.1. Objetivo Geral....................................................... 39

2.2. Objetivos Específicos............................................ 39

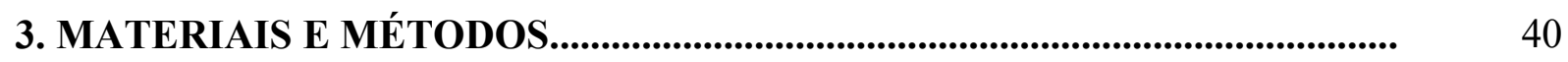

3.1. Animais.......................................................... 40

3.2. Obtenção e preparo de C. burnetii para infecção............................. 40

3.3. Cultura de células de linhagem de mamíferos............................... 40

3.4. Preparo de macrófagos derivados de medula óssea (BMDMs) .................. 41

3.5. Preparo de macrófagos alveolares (AMs) ................................. 41

3.6. Infecção com Coxiella burnetii............................................... 42

3.7. Microscopia de Fluorescência......................................... 42

3.8. Microscopia Eletrônica de Transmissão.................................... 43

3.9. Quantificação de Coxiella burnetii in vitro..................................... 44

3.10. Análises de RT-PCR ................................................ 44

3.11. Citometria de fluxo para análises fenotípicas............................ 45

3.12. Declaração Ética..................................................... 46

3.13. Análises Estatísticas.............................................. 46

4. RESULTADOS.......................................................... 47

4.1. Macrófagos derivados de medula óssea de camundongos A/J são mais suscetíveis à infecção por Coxiella burnetii fase II do que aqueles derivados de camundongos C57BL $/ 6$.

4.2. Macrófagos alveolares derivados de camundongos C57BL/6 são permissivos à replicação de $C$. burnetii fase II. 
4.3. Macrófagos alveolares murinos suportam a replicação de grandes quantidades de bactéria intracelular nos vacúolos contendo $C$. burnetii fase II.........................

4.4. Macrófagos alveolares murinos mostram uma polarização mais pronunciada em células do tipo M2 do que macrófagos murinos derivados de medula óssea.....

4.5. Macrófagos alveolares murinos deficientes em NOS2 e IFN $\gamma$ são mais suscetíveis à replicação de C. burnetii fase II, enquanto células deficientes em interleucina-4 (IL4) são mais restritivas à replicação da bacteria.

4.6. A permissividade dos macrófagos alveolares murinos à infecção por C. burnetii fase II é comparável a aquelas de linhagens celulares imortalizadas altamente suscetíveis

5. DISCUSSÃO

6. SUMÁRIO.

7. CONCLUSÃO. 78

8. REFERÊNCIAS BIBLIOGRÁFICAS. 79

9. ANEXO I - TRABALHO DE PRIMEIRA AUTORIA.

9.1. Anexo 1 - Artigo publicado (FERNANDES, Talita D et al. Infection and Immunity, 2016)

10. ANEXO II - TRABALHOS DE COLABORAÇÃO

10.1. Anexo 2 - Artigo publicado (CUNHA, Larissa D; RIBEIRO, Juliana M; FERNANDES, Talita D; MASSIS, Liliana M; KHOO, Chen A; MOFFATT, Jennifer $\mathrm{H}$; NEWTON, Hayley J; ROY, Craig R; ZAMBONI, Dario S. Nature Communications, 2015).

10.2. Anexo 3 - Artigo publicado (MASCARENHAS, Danielle PA; CERQUEIRA, Daiane M; PEREIRA, Marcelo SF; CASTANHEIRA, Fernanda VS; FERNANDES, Talita D; MANIN, Graziele Z; CUNHA, Larissa D; ZAMBONI, Dario S. Pathogens, 2017) 


\section{INTRODUÇÃO}

\subsection{Coxiella burnetii - Aspectos Gerais}

Coxiella burnetii é uma gama-proteobactéria patogênica gram-negativa intracelular não flagelada que sobrevive no interior de um vacúolo parasitóforo denominado CCV (do

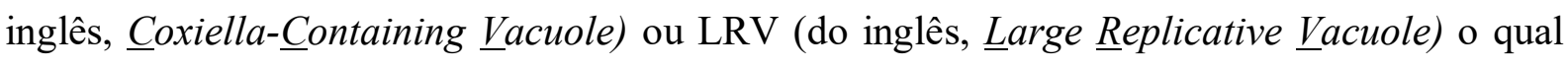
apresenta características fagolisossomais que o tornam único (HACKSTADT; WILLIAMS 1981; WEISBURG et al., 1989; VOTH; HEINZEN 2007; CAPO; MEGE 2012; GHIGO; COLOMBO; HEINZEN, 2012; ANDERSON et al., 2013). Essa bactéria é o agente causador de uma infecção zoonótica denominada Febre Q, que afeta principalmente animais de pastoreio e gado. No entanto, seu reservatório natural é extenso e inclui artrópodes como carrapatos, além de aves, répteis e mamíferos selvagens e domésticos (MAURIN; RAOULT 1999; RAOULT et al., 2005; HECHEMY, 2012; ANDERSON, et al., 2013; ELDIN et al., 2017). A maioria dos animais não desenvolve sintomas aparentes da doença, exceto cabras e ovelhas, as quais apresentam alta proliferação bacteriana no trato reprodutivo feminino, frequentemente levando a abortos tardios e perdas econômicas consideráveis para os produtores (HECHEMY, 2012).

O primeiro surto envolvendo essa bactéria até então desconhecida ocorreu em 1935 em Queensland, Austrália. Nesta ocasião, alguns trabalhadores de um abatedouro em Brisbane foram infectados e começaram a apresentar sintomas de uma doença febril (DERRICK, 1937). Em 1937, Derrick injetou o sangue dos pacientes infectados em porquinhos-da-índia e conseguiu transferir com sucesso a doença, entretanto sem conseguir visualizar seu agente causador. Amostras de tecidos infectados foram então enviadas para o pesquisador Frank Macfarlane Burnet que, juntamente com Mavis Freeman, reproduziram as reações febris características nos porquinhos-da-índia. Eles observaram que os tecidos infectados apresentavam organismos dificilmente filtráveis que aparentavam possuir uma natureza "rickettsial" (BURNET; FREEMAN, 1937; CAPO; MEGE 2012). Testes realizados com o soro de pacientes que tiveram Febre Q e suspensões de tecidos clarificados de cobaias infectadas mostraram a ocorrência de aglutinação. Esse fato ocorria quando era utilizado o soro de pacientes que apresentavam tifo por Rickettsia (BURNET; FREEMAN, 1937; CAPO; MEGE 2012). 
Quase simultaneamente, descobriu-se um agente desconhecido em Hamilton, Montana, nos Estados Unidos, durante estudos de campo sobre a ecologia da febre maculosa das montanhas rochosas. Essa descoberta envolveu a utilização de carrapatos Dermacentor andersoni coletados em Nine Mile, Montana, os quais foram alimentados com porquinhos-daíndia. Um desses animais desenvolveu uma doença febril com características divergentes daquelas comumente apresentadas pela febre maculosa das montanhas rochosas (DAVIS; COX 1938; CAPO; MEGE 2012). Chamado de "agente Nine Mile", esse organismo podia ser transferido serialmente em cobaias, era filtrável e não apresentava crescimento em meio de cultura axênico, o que levou os pesquisadores Davis e Cox (1938) a questionarem sua "natureza bacteriana". A ligação entre o agente Nine Mile e o causador da Febre Q foi descoberta mais tarde. Um paciente infectou-se acidentalmente em laboratório pelo agente Nine Mile e desenvolveu uma febre com de sintomatologia muito semelhante à da Febre Q. Estudos complementares de proteção cruzada desenvolvidos posteriormente demonstraram que ambos os agentes eram o mesmo patógeno (DYER, 1938; DYER, 1939; CAPO; MEGE 2012).

Por não se comportar como uma Rickettsia típica, esse organismo foi inicialmente colocado em um novo gênero na família Rickettsiaceae, o gênero "Coxiella" e espécie "burnetii" em homenagem a Cox e Burnet, respectivamente. Mais tarde, através de estudos com taxonomia molecular envolvendo análises da sequência do gene codificante para $16 \mathrm{~S}$ rRNA, C. burnetii foi reclassificada para o filo Proteobacteria, classe $\gamma$-Proteobacteria, ordem Legionellales e família Coxiellaceae, sendo próxima de Rickettsiella grylli, Legionella pneumophila e Francisella tularensis (WEISBURG et al., 1989; SAUNDERS et al., 1993; ROUX et al., 1997; WAAG; THOMPSON, 2005; RAOULT et al., 2009; CAPO; HECHEMY, 2012; MEGE, 2012; VAN SCHAIK; SAMUEL, 2012; ELDIN et al., 2017). De fato, o genoma de C. burnetii contém uma porcentagem das bases nitrogenadas guanosina e citosina mais próxima do que é encontrado em membros da ordem Legionellales do que membros da ordem Rickettsiales, corroborando sua reclassificação na nova ordem (HECHEMY, 2012).

Quando analisada apenas a sequência do gene 16S rRNA, C. burnetii apresenta uma homogeneidade genética considerável (STEIN; RAOULT, 1993). Todavia, comparações mais amplas de seu genoma por meio da utilização de técnicas como análises de polimorfismos de fragmentos de restrição com diferentes comprimentos (do inglês, Restriction Fragment Lenght Polymorphism - RFLP) e análises de comparação de microarray revelaram 
heterogeneidade considerável no padrão de bandas e nos padrões de hibridização. Essas análises indicaram a existência de diversidade genética entre isolados (HENDRIX et al., 1991; BEARE et al., 2006; HECHEMY, 2012). De fato, a combinação dessas técnicas de análise resultou na categorização inicial de trinta e dois isolados bacterianos em seis grupos genômicos distintos (I-VI) (HENDRIX et al., 1991).

A diversidade genética de $C$. burnetii é também evidenciada pela presença de moléculas de lipopolissacarídeo (LPS) antigênicas e estruturalmente únicas entre diferentes isolados. Foram descritos três quimiotipos de LPS que são associados com grupos genômicos específicos, atuando como biomarcadores únicos de C. burnetii (TOMAN; SKULTETY; IHNATKO, 2009; HECHEMY, 2012; SCHAIK; SAMUEL, 2012). Com o desenvolvimento de métodos de cultivo de C. burnetii em meio axênico) tornou-se possível analisar um número cada vez maior de isolados bacterianos e até mesmo traçar suas origens evolutivas a partir de diferentes técnicas de genotipagem e sequenciamento, como: a) genotipagem de múltiplos espaçadores (do inglês, MST - Multispacer Sequence Typing); b) análise da variação do número de repetições em tandem em múltiplos locus (do inglês, MLVA - Multiple Locus $\underline{V N T R}$ Analysis); c) reação em cadeia da polimerase (do inglês, PCR - Polymerase $\underline{\text { Chain }}$ Reaction) baseada em sítios de restrição pouco frequentes (do inglês, IRS-PCR - Infrequent

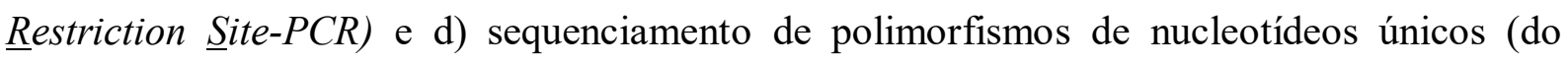
inglês, SNP - iingle Nucleotide Polymorphisms) (GLAZUNOVA et al., 2005; ARRICAUBOUVERY et al., 2006; OMSLAND et al., 2009; HORNSTRA et al., 2011; OMSLAND et al.; 2011 MCLAUGHLIN et al., 2017).

Apesar de ser uma doença de caráter zoonótico, a infecção de seres humanos por $C$. burnetii é recorrente. Ela ocorre via aerossol, por meio da inalação de partículas de ar contaminadas, ou através do contato com fluidos e subprodutos animais infectados, frequentemente provenientes de ruminantes. Os principais alvos celulares primários da infecção são monócitos e macrófagos, especialmente macrófagos alveolares (HACKSTADT; WILLIAMS, 1981; KHAVIN; TABIBZADEH, 1988; MAURIN; RAOULT 1999; SHANNON; HEINZEN 2008; CAPO; MEGE 2012). Nos humanos, a infecção com $C$. burnetii pode resultar em soroconversão assintomática ou no desenvolvimento da Febre Q sintomática. Em sua fase aguda, apresenta manifestações clínicas variadas com características semelhantes a de uma gripe, incluindo pneumonia, febre, dores de cabeça, calafrios, fadiga e hepatite granulomatosa (RAOULT; MARRIE; MEGE, 2005; CAPO; MEGE 2012; HECHEMY, 2012). A falta de sintomas específicos na fase aguda da infecção, as variações 
nos períodos de incubação da bactéria e as dificuldades do emprego de metodologias de diagnóstico específicas para detecção de C. burnetii em muitos hospitais sugerem que a mesma é, provavelmente, subdiagnosticada. Mais da metade dos pacientes infectados não exibe nenhum sintoma, sendo a infecção aguda autolimitante. Ainda assim, um estudo feito no Brasil por Costa e colaboradores (2006) sugere que cerca de 4,5\% dos casos de febres do tipo influenza, febres de origem desconhecida e pneumonias atípicas sejam causados por $C$. burnetii.

Apesar da maior parte dos casos de infecção ser assintomática e se resolver sem tratamento específico com antibióticos, cerca de 2-5\% desses casos ou de casos de Febre Q aguda evoluem para a Febre Q crônica, forma mais séria da doença. Suas manifestações clínicas mais sérias incluem endocardite, apresentando fibrose, calcificação, inflamação leve e vascularização, frequentemente levando o paciente à hospitalização. $\mathrm{Na}$ ausência do tratamento adequado, pode resultar na morte do paciente (RAOULT, 1990; BACA; LI; KUMAR, 1994; MAURIN; RAOULT, 1999; RAOULT; MARRIE; MEGE, 2005; CAPO; MEGE 2012; HECHEMY, 2012).

Dados epidemiológicos mostram que gênero masculino, idade superior a 15 anos, imunocomprometimento e doenças cardíacas valvulares pré-existentes compreendem fatores de risco importantes para o desenvolvimento da Febre Q (CAPO; MEGE 2012; HECHEMY, 2012). Além disso, mesmo em pacientes que apresentam aparente cura, a C. burnetii persiste em seus organismos por um longo período de tempo, impactando na saúde a longo prazo. Mais de um terço dos pacientes continuam a apresentar estado de saúde prejudicado mesmo apó 24 meses do diagnóstico da infecção (HARRIS et al., 2000; VAN DER VELDEN et al., 2015).

Análises epidemiológicas mostraram que a infecção com C. burnetii apresenta distribuição mundial, com exceção da Nova Zelândia (MAURIN; RAOULT, 1999; RAOULT; MARRIE; MEGE, 2005; MARRIE, 2010; ELDIN et al., 2017). Além disso, por ser uma doença zoonótica, a epidemiologia humana da Febre Q reflete a circulação da bactéria nos reservatórios animais. No mundo, situações endêmicas ou surtos são observados dependendo da área geográfica. Comumente, áreas de endemicidade como França, Espanha e Estados Unidos apresentam casos esporádicos de Febre Q. Esses casos são observados após a realização de atividades de alto risco por seres humanos, como trabalhos em fazenda, matadouros e áreas rurais em geral. Pequenos surtos também podem ocorrer após exposição a fontes comuns de infecção, principalmente em ambiente familiar (ELDIN et al., 2017). 
Existem áreas de hiperendemicidade, como a África, nas quais a transmissão da doença é facilitada devido a uma alta concentração de lares muito próximos a grandes populações de ruminantes domésticos. $\mathrm{O}$ consumo de leite cru não pasteurizado nessas áreas também pode atuar como fonte de contaminação humana por C. burnetii. Um importante surto de larga escala foi observado na Holanda entre os anos 2007 e 2010, onde mais de 4.000 novos casos foram noticiados. Esse surto apresentou correlação com o aumento da importação de cabras no país entre os anos 1985 e 2009 para fortalecimento das atividades de criação de laticínios provenientes desses animais. A introdução de animais contaminados com C. burnetii em regiões próximas de áreas urbanas pode ter favorecido o desenvolvimento do surto (DELSING; KULLBERG; BLEEKER-ROVERS, 2010; SCHNEEBERGER et al., 2012).

Além de sua distribuição mundial, C. burnetii apresenta alta estabilidade no ambiente e é altamente virulenta, sendo necessário uma dose infecciosa muito baixa ( $<10$ organismos) para causar a doença. À partir das características apresentadas e da capacidade de aerosolização do patógeno, C. burnetii foi classificada pelo Centro para Controle e Prevenção de Doenças dos Estados Unidos como agente potencial de bioterrorismo da categoria B (MARRIE, 2004; ELDIN et al., 2017). Com isso, reforça-se a importância de se estudar essa bactéria e todos os aspectos envolvidos na infecção por esse patógeno.

A alta estabilidade de $C$. burnetii no ambiente deve-se a particularidades existentes em seu ciclo de vida de caráter bifásico. Ele envolve a participação de duas variantes celulares

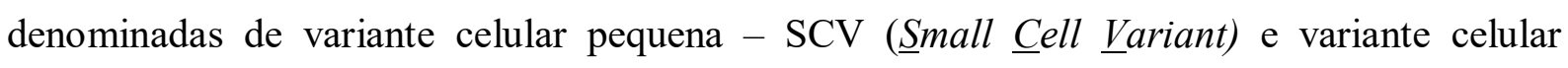

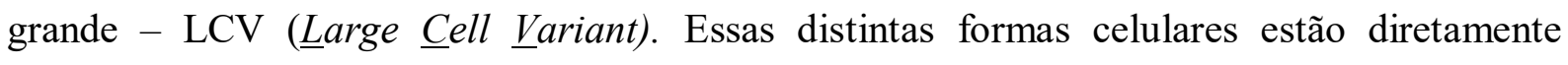
relacionadas com os diferentes ambientes que a bactéria enfrenta, sendo eles o meio extracelular (para SCV) e o meio intracelular (principalmente para LCV). Quando no meio externo, C. burnetii encontra-se na forma de cocobacilo com cerca de 0,2-0,5 $\mu \mathrm{m}$ de comprimento. Quando vista ao microscípio, a SCV apresenta-se altamente elétron-densa devido ao estado extremamente condensado de sua cromatina. Essa condensação relaciona-se com o fato de que esse morfotipo celular é metabolicamente inativo e se assemelha a uma forma de resistência, tendo sido inicialmente confundido com um esporo. A SCV, considerada a forma infectiva da bactéria, é resistente à dissecação, altas temperaturas, choques osmóticos, luz ultravioleta e agentes químicos desinfectantes, permitindo que essa forma celular permaneça infecciosa no ambiente por meses (MCCAUL; WILLIANS, 1981; WILLIANS, 1991; COLEMAN et al., 2004; TISSOT-DUPONT et al., 2004; MINNICK; 
RAGHAVAN, 2012; VAN SCHAIK; SAMUEL 2012; SANDOZ et al., 2014; ELDIN et al., 2017).

Ao entrar em contato com seu hospedeiro, a SCV é fagocitada, inicia-se uma série de mudanças conformacionais e metabólicas que acompanham desde a maturação do endossomo até o estabelecimento do vacúolo parasitóforo contendo C. burnetii. Essas mudanças são acompanhadas de uma transição da SCV para a LCV, forma replicativa bacteriana com cerca de $1 \mu \mathrm{m}$ de comprimento. A duração desse processo é de aproximadamente dois dias e caracteriza a fase lag do crescimento bacteriano, em que não há replicação (COLEMAN et al., 2004). A transição entre a variante SCV, essencialmente dormente, para a LCV, pleiomórfica e metabolicamente ativa, ocorre em resposta à acidificação do $\mathrm{CCV}$ e, provavelmente, a outros sinais como disponibilidade de nutrientes na célula hospedeira e ações enzimáticas (HACKSTADT; WILLIAMS, 1981; SESHADRI; HENDRIX; SAMUEL, 1999; MINNICK; RAGHAVAN 2012; VAN SCHAIK; SAMUEL, 2012; SANDOZ et al., 2014). ScyA é uma proteína de ligação ao DNA de caráter altamente básico que, provavelmente, desempenha um papel na condensação da cromatina. A perda da sua atividade interfere com a manutenção do estado metabolicamente inativo da variante SCV e é um dos marcos que sinalizam a transição da SCV para LCV (COLEMAN et al., 2004; VAN SCHAIK; SAMUEL, 2012). Uma vez que essa transição é finalizada inicia-se a fase de crescimento exponencial da bactéria, denominada fase $\log$. Nessa etaá, as LCV irão replicar por aproximadamente quatro dias até atingir a fase $\log$ tardia ou o início da fase estacionária. Nesse momento, observa-se o reaparecimento da proteína ScyA e uma nova transição da forma $\mathrm{LCV}$ para $\mathrm{SCV}$ de $C$. burnetii, com a lise das células infectadas e a liberação de novas SCV que infectarão outras células. Com isso, finaliza-se um ciclo de vida bifásico dessa bactéria e inicia-se o próximo (Figura 1) (COLEMAN et al., 2004; MINNICK; RAGHAVAN 2012; VAN SCHAIK; SAMUEL, 2012; SANDOZ et al., 2014). 

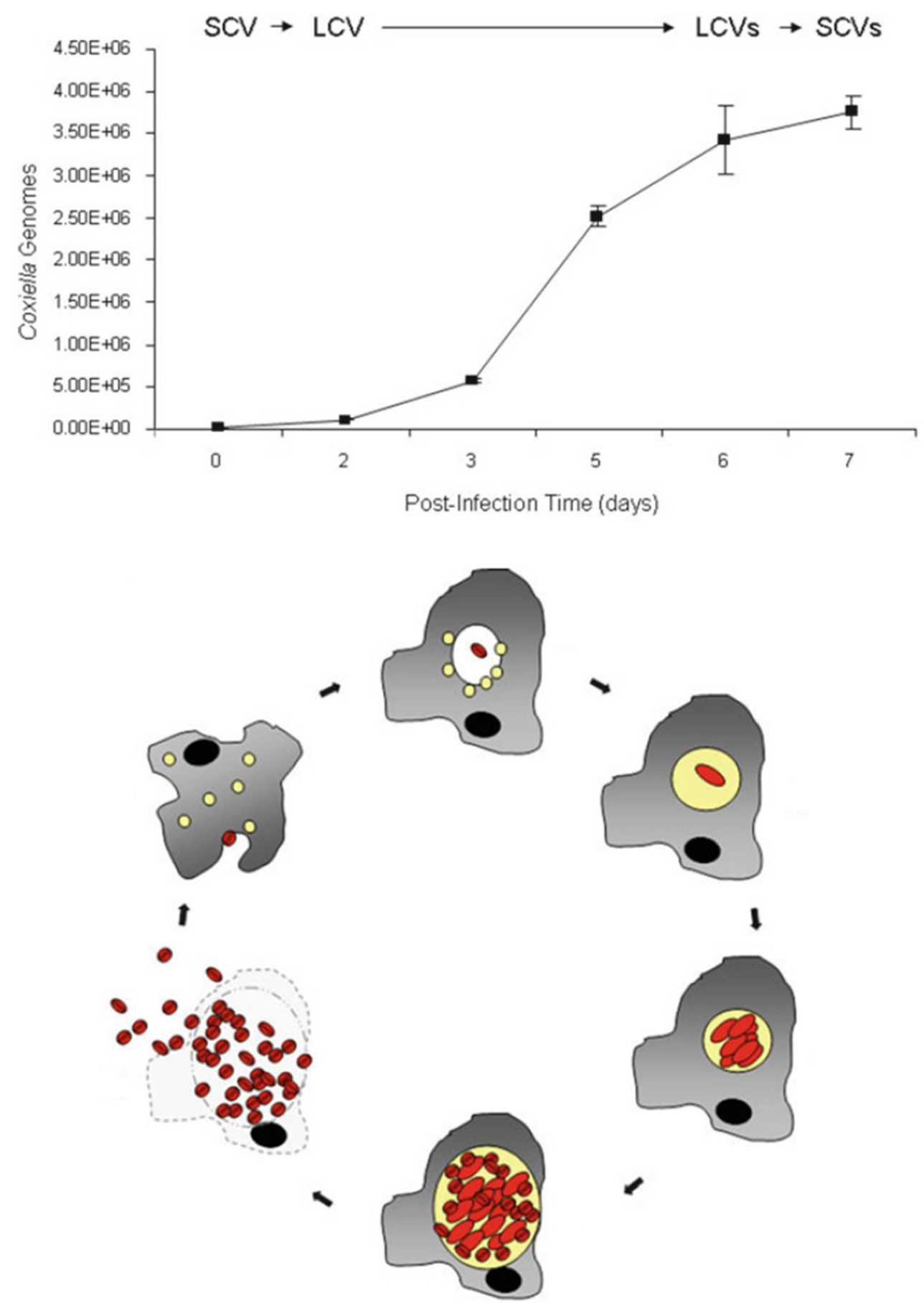

Figura 1 - Representação do ciclo de vida bifásico de $\boldsymbol{C}$. burnetii. Após a internalização da SCV de $C$. burnetii pela célula hospedeira, ocorre o desenvolvimento de um fagossomo, seguido do recrutamento e fusão de lisossomos (ćŕrculos amarelos) para esse compartimento. O vacúolo parasitóforo sofre acidificação, levando à transição da SCV para LCV, finalizando a fase lag do ciclo com duração de dois dias. Posteriormente, ocorre a replicação exponencial das LCVs, caracterizando a fase $\log$ do ciclo, com duração aproximada de quatro dias. No período tardio dessa fase inicia-se novamente a transição da LCV para SCV, iniciando a fase estacionária do ciclo, até a lise da célula hospedeira e liberação das SCVs que infectarão outras células. Adaptado de: Minninck; Raghavan (2012). 


\subsection{O vaúcolo parasitóforo de Coxiella burnetii e sua interação com vias do hospedeiro}

Para a sobrevivência e replicação de $C$. burnetii no interior da célula hospedeira é essencial que ela estabeleça seu vacúolo parasitóforo e o mantenha durante todo o seu desenvolvimento. Além disso, macrófagos e monócitos são as principais células-alvo da infecção por C. burnetii e desempenham papéis importantes em processos biológicos como processamento e apresentação de antígenos, produção de citocinas e eliminação de patógenos. Portanto, é fundamental que a bactéria evite ou subverta suas respostas (AMARA; BECHAH; MEGE, 2012). Ambos os processos dependem da participação ativa da bactéria, em parte por meio da utilização de seu sistema de secreção tipo IVB, homólogo ao sistema de secreção Dot/Icm da bactéria Legionella pneumophila (SESHADRI et al., 2003; ZAMBONI et al., 2003; ZUSMAN; YERUSHALMI; SEGAL, 2003). Esse sistema de secreção é montado em resposta à acidificação do ambiente de uma organela endocítica tardia em que a bactéria se encontra. Ele facilita a translocação de mais de 130 proteínas efetoras no citoplasma da célula hospedeira que, conjuntamente, colaboram para modulação do vacúolo contendo C. burnetii e para a modulação das repostas imunes do hospedeiro, fornecendo um ambiente favorável à replicação bacteriana (HOWE et al., 2003; NEWTON; MCDONOUGH; ROY, 2013; MOFFATT; NEWTON P.; NEWTON H.J., 2015).

O processo de estabelecimento do vacúolo parasitóforo contendo C. burnetii começa com sua internalização pela célula hospedeira. Após a descoberta do sistema de secreção tipo IV (T4SS) nessas bactérias sugeriu-se a utilização de mecanismos ativos para indução da fagocitose após ligação inicial à célula hospedeira. No entanto, estudos realizados com bactérias mutantes para T4SS demonstraram que não houve interferência na habilidade dessas bactérias de invadir células fagocíticas e não fagocíticas (BEARE et al., 2011). Esses dados corroboram a hipótese de que o processo de entrada de C. burnetii nas células hospedeiras ocorre, na realidade, de forma passiva, envolvendo o remodelamento de filamentos de actina em um mecanismo de zíper (BACA; KLASSEN; ARAGON, 1993; TUJULIN et al., 1998; BEARE et al., 2011; CAREY et al., 2011; VAN SCHAIK et al., 2013). De fato, o tratamento das células hospedeiras com agentes despolimerizantes de actina, como citocalasina $\mathrm{D}$, inibem a internalização do patógeno, ressaltando a importância dos filamentos de actina para entrada da bactéria (BACA; KLASSEN; ARAGON, 1993).

Após a entrada na célula hospedeira, a bactéria trafega passivamente pela via endocítica, participando de diferentes etapas de maturação, antes de atingir o ambiente tipicamente acidificado e hidrolítico dos lisossomos. Diferentemente de outros patógenos que 
são comumente degradados neste ambiente, C. burnetii é capaz de sobreviver e continuar seu ciclo de desenvolvimento (HACKSTADT; WILLIAMS, 1981; HEINZEN et al., 1996; VOTH; HEINZEN, 2007).

O início do processo de maturação do fagossomo contendo C. burnetii envolve fissão e fusão com vários endossomos iniciais, apresentando diferentes marcadores de membrana e alterações de $\mathrm{pH}$ do lúmen. Após cinco minutos de internalização bacteriana é possível detectar marcadores como o Antígeno-1 de Endossomos Iniciais (EEA1, do inglês Éarly Endosome Antigen-1) e a GTPase Rab5, além de alteração na acidificação do lúmen para pH 5,4, aproximadamente. Diferentemente do que ocorre para a maioria dos patógenos, foi observado que $C$. burnetii interage com a via de autofagia. Essa interação foi identificada a partir da presença da proteína de cadeia leve 3 associada a microtúbulo (LC3, do inglês LightChain 3), marcadora de autofagia, na membrana fagossomal (BERON et al., 2002; ROMANO et al., 2007; VAN SCHAIK et al., 2013).

Os fagossomos iniciais continuam trafegando pela via endocítica até completar 60 minutos, aproximadamente, após a entrada na célula hospedeira. A partir desse momento, há a substituição gradual dos marcadores de endossomos iniciais por marcadores de endossomos tardios, como a GTPase Rab7, a proteína 1 associada à membrana lisossomal (LAMP-1, do

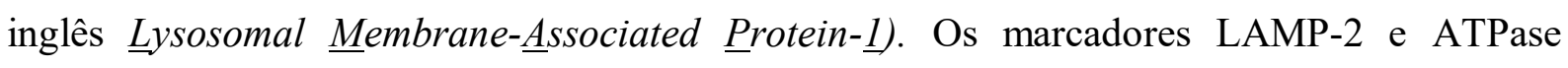
vacuolar também estão presentes e são responsáveis por reduzir o $\mathrm{pH}$ do vacúolo para valores próximos a 5, através do bombeamento de prótons no fagossomo em maturação (SCOTT; BOTELHO; GRINSTEIN, 2003; HENRY et al., 2004; ROMANO et al., 2007; GHIGO et al., 2009; GHIGO; COLOMBO; HEINZEN, 2012). Posteriormente ocorre a fusão dos fagossomos com lisossomos, formando os chamados fagolisossomos. Nesse evento, hidrolases lisossomais e enzimas como fosfatase ácida e catepsina D são recrutadas em um processo que é ativamente atrasado pela bactéria. Essa modulação da maturação final do vacúolo por C. burnetii pode estar relacionada com novas interações com as vias autofágicas da célula. Desse modo, vesículas autofágicas cheias de nutrientes e membranas provenientes de suas cargas degradadas se fundem ao vacúolo em maturação, favorecendo assim a posterior replicação do patógeno (HOWE et al., 1993; HOWE; MALLAVIA, 2000; GUTIERREZ et al., 2005; ROMANO et al., 2007; VOTH; HEINZEN, 2007; VAN SCHAIK; SAMUEL, 2012; VAN SCHAIK et al., 2013).

Em seguida, há um aumento drástico no volume do vacúolo bacteriano, resultando no deslocamento das organelas da célula hospedeira para a periferia, ocupando quase todo o 
volume citoplasmático disponível. Essa expansão ocorre por meio de fusão homotípica entre múltiplos vacúolos de menor tamanho contendo $C$. burnetii, um processo que requer a participação de proteínas do hospedeiro. Entre elas, encontram-se as proteínas que mediam diretamente eventos de fusão de vesículas (SNAREs, do inglês Soluble NSF-attachment receptor), bem como a participação de efetores bacterianos translocados pelo sistema de secreção. Dentre as proteínas SNAREs potencialmente envolvidas no processo de fusão homotípica, foram identificadas VAMP-3, VAMP-7 e VAMP-8, bem como a proteína Syntaxin-7, a qual se assemelha a uma proteína SNARE (ITAKURA; KISHI-ITAKURA; MIZUSHIMA, 2012; CAMPOY; MANSILLA; COLOMBO, 2013; HAMASAKI et al., 2013; MCDONOUGH et al., 2013; NEWTON et al., 2014; KOHLER; ROY, 2015; PECHSTEIN; SCHULZE-LUEHRMANN; LÜHRMANN, 2018). Com relação aos efetores bacterianos envolvidos nesse processo, $\mathrm{CvpB}$, também conhecida como Cig2, é essencial para fusão homotípica dos vacúolos. Foi demonstrado que a interferência nesse efetor através do uso de transposons resultou em múltiplos vacúolos contendo C. burnetii por célula sem capacidade de fusão, impossibilitando a formação do vacúolo único característico (NEWTON; MCDONOUGH; ROY, 2013; NEWTON et al., 2014; WEBER; FARIS, 2018). A expansão do vacúolo continua por meio de eventos de fusão heterotípica com vesículas lisossomais, autofágicas, endocíticas e exocíticas (HOWE et al., 2003a; HOWE et al., 2003b; CAMPOY; ZOPPINO; COLOMBO, 2011).

A manutenção do vacúolo parasitóforo depende da participação do citoesqueleto de actina, da produção de proteínas pela bactéria e da ativação de proteínas quinase do hospedeiro como proteína quinase da cadeia leve de miosina, proteína quinase A e proteína quinase C (AGUILERA et al., 2009; HUSSAIN et al., 2010; VAN SCHAIK et al., 2013). Além disso, o acúmulo de RAB1B e RhoGTPase na membrana do vacúolo demonstra a interação com o retículo endoplasmático e as vias secretórias iniciais, sugerindo o fornecimento de membrana para o vacúolo em expansão (CAMPOY; ZOPPINO, COLOMBO, 2011; VAN SCHAIK; SAMUEL, 2012). Efetores bacterianos como CvpA e Cig57 estão envolvidos com a subversão do tráfego de vesículas mediado por clatrina, facilitando a biogênese do vacúolo fusogênico (LARSON et al., 2013; LATOMANSKI et al., 2016; PECHSTEIN; SCHULZE-LUEHRMANN; LÜHRMANN, 2018).

A membrana do vacúolo parasitóforo contendo C. burnetii apresenta enriquecimento de colesterol, fato atípico para membranas de compartimentos com características lisossomais. A infecção com essa bactéria induz o aumento na expressão de genes envolvidos 
com a produção de colesterol, além da bactéria expressar uma enzima esterol redutase que pode afetar o metabolismo de colesterol do hospedeiro (COLEMAN et al., 2004; HOWE; HEINZEN, 2006; GILK; BEARE; HEINZEN, 2010; KOHLER; ROY, 2015). Essas interações bacterianas com diferentes vias do hospedeiro requerem que a produção de proteínas por $C$. burnetii esteja intacta, sugerindo a possivel participação de vários outros efetores bacterianos nesses processos (ZAMBONI et al., 2003; CAMPOY; ZOPPINO, COLOMBO, 2011).

C. burnetii é capaz de intervir nas vias apoptóticas da célula hospedeira, inibindo a apoptose celular. Isso se dá pela interferência em diferentes etapas da via de apoptose, por exemplo: a) antagonização do processamento de caspase-3, caspase-9 e PARP ( $\underline{\text { Poly }} \underline{A}$ DPRibose Processing); b) alteração dos níveis de expressão de mais de 30 genes prósobrevivência, e c) ativação sustentada do fator de transcrição NF-אB (VOTH; HOWE; HEINZEN, 2007a; VOTH; HOWE; HEINZEN, 2007b; HUSSAIN; VOTH, 2012). Outra interação utilizada pela bactéria com as vias de apoptose inclui o recrutamento do complexo anti-apoptótico formado por Beclin-1/Bcl-2 para a membrana do vacúolo parasitóforo, possivelmente por meio de prevenção da liberação de citocromo $\mathrm{C}$ das mitocôndrias, ação conhecida de Bcl-2 (YANG et al., 1997; LUHRMANN; ROY, 2007). Esse complexo Beclin1/Bcl-2 também participa da regulação da autofagia. A modulação positiva de vias de sinalização pró-sobrevivência mediadas por Akt e Erk1/2 pela bactéria, com a ativação sustentada dessas proteínas, contribui para inibição da apoptose (GUTIERREZ et al., 2005; LUHRMANN; ROY, 2007; ROMANO et al., 2007; VOTH et al., 2007; VOTH; HEINZEN, 2009; VAZQUEZ, COLOMBO, 2010; VAN SCHAIK; SAMUEL, 2012).

Luhrmann e colaboradores (2010) demonstraram que AnkG é um dos efetores bacterianos envolvidos na indução do estado anti-apoptótico de células infectadas com $C$. burnetii, por meio de sua interação com a proteína p32 do hospedeiro. O efetor bacteriano CaeB localiza-se na membrana da mitocôndria e previne a liberação de proteínas próapoptóticas através da inibição da permeabilização dessa membrana, enquanto CaeA, outra proteína efetora bacteriana, apresenta localização nuclear e inibe a apoptose por mecanismos ainda não esclarecidos (LUHRMANN et al., 2010; KLINGENBECK et al., 2013; VAN SCHAIK et al., 2013). Em conjunto, esses fatores demonstram que o vacúolo parasitóforo maduro contendo C. burnetii metabolicamente ativa não é estático e que a bactéria é capaz de modular e interagir ativamente com diversas vias do hospedeiro, garantindo dessa forma a manutenção de seu nicho replicativo (Figura 2) (HEINZEN et al., 1996; HOWE; HEINZEN, 
2006; CAMPOY; ZOPPINO; COLOMBO, 2011; VAN SCHAIK et al., 2013; KOHLER; ROY, 2015)

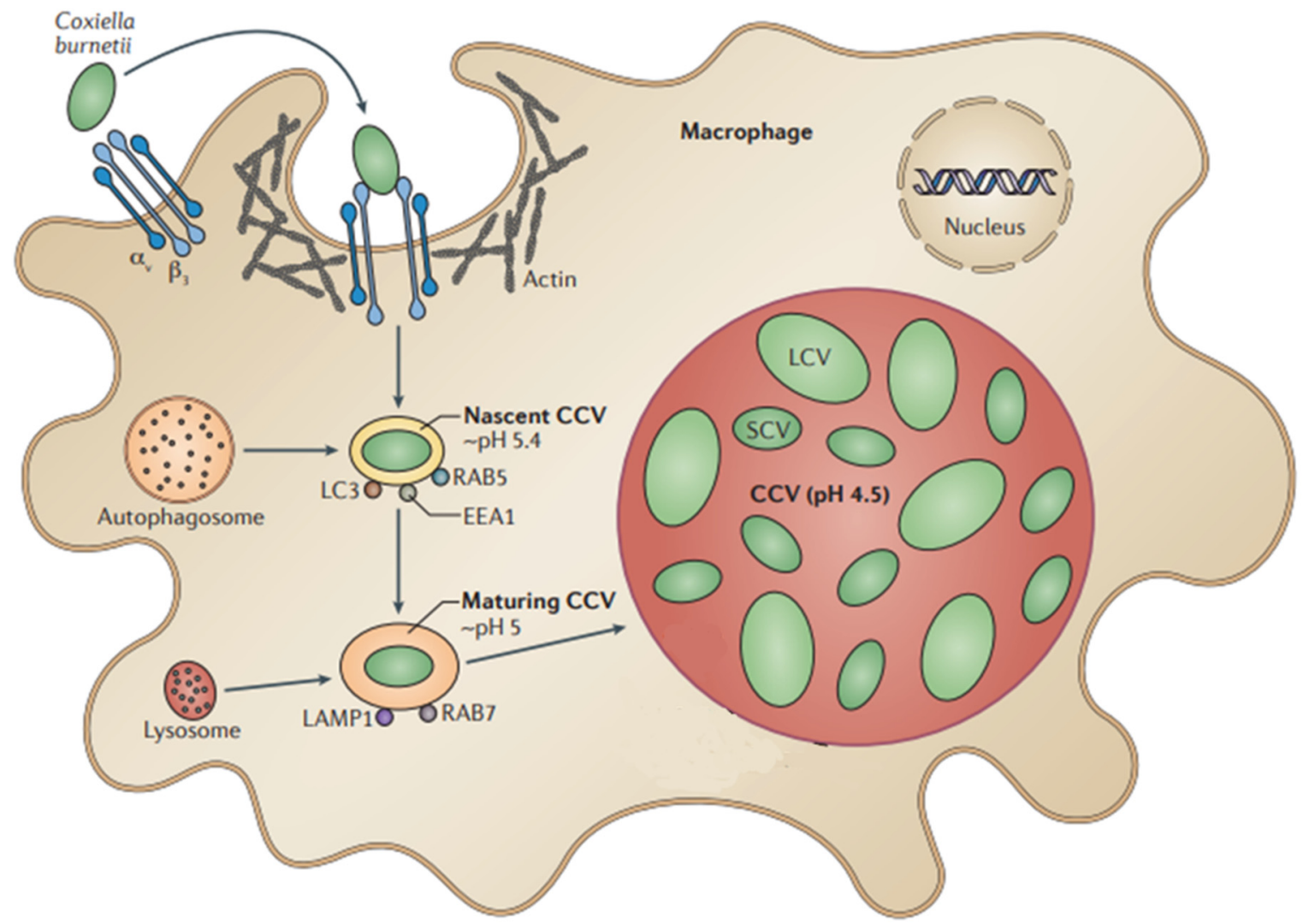

Figura 2 - Processo de desenvolvimento e maturação do vacúolo contendo $C$. burnetii. Após a internalização da SCV de C. burnetii pela célula hospedeira, em um processo que envolve a remodelação de filamentos de actina e interação com os receptores $\alpha \mathrm{V} \beta 3$ integrina, ocorre a formação de um fagossomo que trafega pela via endocítica. Durante esse tráfego ocorre a interação com endossomos e lisossomos, marcada pela aquisição de marcadores como LC3, RAB5, EEA1, LAMP1 e RAB7, juntamente com uma diminuição de pH, até a maturação final do vacúolo contendo C. burnetii que apresenta características fagolisossomais. Adaptado de: Van Schaik e colaboradores (2013).

\subsection{Ativação e subversão da resposta imune por Coxiella burnetii}

Além de interagir com diferentes vias e componentes das células hospedeiras a fim de assegurar o estabelecimento e manutenção de seu vacúolo replicativo, C. burnetii precisa garantir que o sistema imune dos hospedeiros não seja capaz de detectá-la. Com isso, é possível montar uma resposta efetiva contra o patógeno. Além do papel do sistema de 
secreção do tipo IVB e das interações da bactéria com vias de autofagia e apoptose, $C$. burnetii é capaz de subverter a atividade microbicida de monócitos e macrófagos, principais células alvo da infecção por esse patógeno. Essa subversão ocorre por meio de diversos mecanismos, os quais podem ser diretos ou indiretos. Como mecanismo direto tem-se a ação dos efetores bacterianos, por exemplo. Já como mecanismos indiretos têm-se as alterações no estado de polarização dos macrófagos ou a interferência com citocinas regulatórias (AMARA; BECHAH; MEGE, 2012).

Uma das estratégias empregadas por essa bactéria consiste na subversão da fagocitose, processo que apresenta diferenças entre a infecção com a forma virulenta ou avirulenta de $C$. burnetii (CAPO et al., 1999). A diversidade genética e o potencial de virulência de C. burnetii reside principalmente nas diversas formas de LPS expressos. Bactérias do isolado RSA493, derivadas da cepa Nine Mile, são chamadas de "fase I" ou virulentas quando apresentam LPS do tipo liso (com uma cadeia de polissacarídeos com o antígeno-O completo e presente, bem como resíduos frequentes dos açúcares virenose e diidrohidroxistreptose) (NARASAKI; TOMAN, 2012). Já a variante Nine Mile "fase II", conhecida como a forma avirulenta para mamíferos, é obtida por meio de passagens seriais da forma virulenta em hospedeiros não imunocompetentes. Com isso, ocorrem modificações irreversíveis na estrutura do LPS, com perda do antígeno-O, podendo ou não apresentar deleções genômicas adicionais. Como resultado, o LPS das bactérias fase II apresenta um fenótipo rugoso. Diferentemente, o lipídeo A presente no LPS das formas virulentas e avirulentas de C. burnetii apresenta as mesmas espécies iônicas e perfis de fragmentação iguais, sugerindo uma estrutura similar entre eles (VISHWANATH; HACKSTADT, 1988; TOMAN; SKULTETY, 1996; MAURIN; RAOULT, 1999; ZAMBONI et al., 2004; TOMAN; SULTETY; IHNATKO, 2009; NARASAKI; TOMAN, 2012; VAN SCHAIK et al., 2013; ELDIN et al., 2017).

A subversão da fagocitose por C. burnetii difere entre a fase I e II, pois os receptores envolvidos nesse processo variam de acordo com o tipo de LPS apresentado (WILLIAMS; PEACOCK; MCCAUL, 1981; HACKSTADT, 1988; AMARA; BECHAH; MEGE, 2012; VAN SCHAIK et al., 2013; LARSON et al., 2016). A fagocitose das formas avirulentas da bactéria depende da participação de receptores de integrina $\alpha \mathrm{V} \beta 3$ e também de receptores CR3 (do inglês, Complement Receptor 3). Dessa forma, ocorre uma alta taxa de internalização, o que pode interferir com a sobrevivência da bactéria. A maior exposição de proteínas e a hidrofobicidade aumentada desse tipo de LPS devido à falta do antígeno-O provavelmente facilitam as interações entre a membrana plasmática do hospedeiro e da 
bactéria, o que explicaria essa maior facilidade para fagocitose da fase II. Já as formas virulentas de C. burnetii desacoplam o receptor CR3 do processo, interagindo apenas com as integrinas $\alpha \mathrm{V} \beta 3$ e levando a uma taxa baixa de fagocitose e sobrevivência intracelular. É possível que a interação de ambas as formas da bactéria com as $\alpha \mathrm{V} \beta 3$ integrinas ocorra por meio de proteínas associadas a membranas que apresentam o domínio de ligação a integrinas composto por arginina-glicina-ácido aspártico (domínio RGD) ou proteínas com domínios anquirina (CAPO et al., 1999; SESHADRI et al., 2003; VAN SCHAIK et al., 2013; CAPO; MEGE, 2012; ELDIN et al., 2017). É importante ressaltar que no caso da fagocitose das formas virulentas ocorre também a indução de protusões na membrana para restringir ainda mais o acesso aos receptores CR3. Esse processo está relacionado com o forte remodelamento do citoesqueleto de actina, além da ativação de vias de proteínas tirosina quinase, produção deficiente de citocinas como IL-12 e TNF, e inibição da maturação de células dendríticas (BACA; KLASSEN; ARAGON, 1993; MECONI et al., 1998; CAPO et al., 1999; DELLACASAGRANDE et al., 2000; MECONI et al., 2001; SHANNON; HOWE; HEINZEN, 2005; CAPO; MEGE, 2012; VAN SCHAIK; SAMUEL, 2012; VAN SCHAIK et al., 2013; LARSON et al., 2016; ELDIN et al., 2017).

O remodelamento do citoesqueleto de actina induzido pela infecção de macrófagos com C. burnetii fase I também conta com a participação de receptores do tipo Toll (TLRs, do

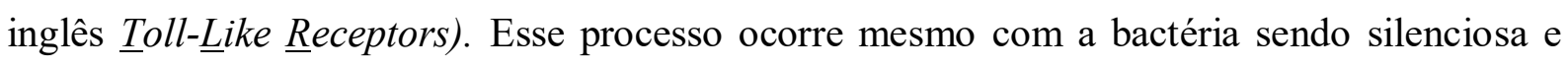
altamente adaptada à evasão do sistema imune, incluindo evasão do reconhecimento pelo sistema complemento e do reconhecimento e desencadeamento de resposta imune mediada pelos TLRs (VISHWANATH; HACKSTADT; 1988; ZAMBONI, 2004; ZAMBONI et al., 2004; VAN SCHAIK et al., 2013). Os TLRs são uma classe de receptores da imunidade inata denominados PRRs (do inglês, Pattern Recognition Receptors), identificados pela primeira vez em Drosophila melanogaster devido ao seu papel no controle do desenvolvimento dorsoventral desse inseto (LEMAITRE et al., 1996). Apresentam uma estrutura básica composta por um domínio N-terminal extracelular de reconhecimento rico em repetições de leucina (do inglês, Leucine-Rich Repeat - LRR), um domínio transmembrana e um domínio C-terminal intracelular de sinalização (MEDZHITOV; PRESTON-HULBURT; JANEWAY, 1997; MEDZHITOV, 2001). Essas proteínas reconhecem, de forma geral, padrões moleculares associados a micróbios (MAMPs, do inglês Microbe-Associated Molecular $\underline{\text { Patterns) }}$ e padrões moleculares associados a danos (DAMPs, do inglês $\underline{\text { Damage-Associated }}$ Molecular Patterns) provenientes de células que estão morrendo ou que apresentam algum 
dano (JANEWAY, 1989; MEDZHITOV; JANEWAY, 1997; SATOH; AKIRA, 2016). Até o momento, foram identificados 13 receptores do tipo TLR em camundongos, sendo que 10 desses receptores são compartilhados com seres humanos (ROCK et al., 1998). Esses receptores localizam-se na membrana plasmática das células, como é o caso de TLR1, TLR2, TLR4, TLR5 e TLR6, ou em endossomos, como ocorre com TLR3, TLR4, TLR7, TLR8, TLR9 e TLR13 (O'NEILL et al., 2013). No caso dos TLRs endossomais, o domínio Nterminal de reconhecimento encontra-se no interior do endossomo (CREAGH; O'NEILL, 2006).

Os receptores TLRs reconhecem moléculas presentes em protozoários, fungos, bactérias e vírus. Entre os TLRs capazes de reconhecer proteínas bacterianas encontram-se TLR2, TLR4 e TLR5. O TLR2 reconhece lipoproteínas, glicolipídios, peptidioglicanas, ácidos lipoteicóicos, zimosam e manana derivadas de bactérias Gram-positivas. A proteína flagelina presente nos flagelos bacterianos ativa TLR5 Além de reconhecer LPS presente na parede celular de bactérias Gram-negativas, TLR4 também é ativado por proteínas do envelope do vírus sinsicial, fosfolipídios glicoinositol de tripanossomos e proteínas heat shock 60 e 70. (AKIRA; TAKEDA, 2004; MEDZHITOV; JANEWAY, 2000; SATOH; AKIRA, 2016). De modo geral, a sinalização via TLRs tem como consequência a indução da produção de quimiocinas, citocinas pró-inflamatórias e da transcrição de genes envolvidos com a produção de proteínas que atuam na resposta imune inata como caspase-1, caspase-11 e NLRP3 (do inglês, $\underline{N} L R$ family of $\underline{P} Y R I N$ domain containing Protein $\underline{3}$ ). Além de induzir a produção de citocinas pró-inflamatórias como interferons (IFNs) do tipo I, fator de necrose tumoral (TNF) e interleucina(IL)-12, a sinalização via TLRs participa da produção de formas precursoras das citocinas pró-inflamatórias pró-IL-1 $\beta$ e pró-IL-18. Esse importante processo prepara as células para a ativação de outras vias do sistema imune inato, como por exemplo a formação de plataformas moleculares intracelulares conhecidas como inflamassomas em resposta ao reconhecimento de patógenos (KAWAI; AKIRA, 2011; LATZ; XIAO; STUTZ, 2013).

Como foi dito anteriormente, a entrada de C. burnetii fase I nas células e o remodelamento de actina que ocorre durante esse processo são dependentes de TLRs, principalmente TLR4. Macrófagos deficientes para TLR4 apresentam entrada bacteriana prejudicada e produção reduzida de citocinas pró-inflamatórias. No entanto, ainda dispõem de formação defectiva e transiente de granulomas, uma das formas conhecidas de resposta imune sistêmica mediada por células que atuam na tentativa de controlar a infecção por $C$. burnetii 
(HONSTETTRE et al., 2004). Após a descoberta da estrutura tetra-acilada do lipídio-A de $C$. burnetii verificou-se que o mesmo atua como antagonista da sinalização via TLR4 (ZAMBONI et al., 2004; CUNHA; ZAMBONI, 2012). Este mecanismo de evasão da resposta imune que ocorre tanto em bactérias fase I quanto fase II já foi observado também em outras bactérias patogênicas, como Yersinia pestis (TELEPNEV et al., 2009; VAN SCHAIK et al., 2013). Esse antagonismo é um processo complexo e parece envolver, ao menos no caso das bactérias fase I, o desencadeamento prejudicado da ativação de vias de MAPK em macrófagos. Este mecanismo é importante para evitar a conversão de fagolisossomos contendo a bactéria em compartimentos degradativos contendo catepsina D e, assim, favorecer a sobrevivência da bactéria (BARRY et al., 2012).

Outro importante receptor da família dos TLRs que está envolvido na resposta imune à C. burnetii é o TLR2. As formas avirulentas da bactéria podem ser reconhecidas por TLR2, induzindo a ativação de respostas imunes do tipo I, com produção de IL-12 e TNF. Essas citocinas contribuem para o controle da infecção em macrófagos murinos Macrófagos deficientes para TLR2 apresentam permissividade aumentada para a replicação bacteriana em relação a macrófagos selvagens ou deficientes para TLR4, corroborando o importante papel do receptor TLR2 na restrição do crescimento de C. burnetii. No entanto, o mesmo não ocorre para a forma virulenta da bactéria. No caso da fase I, o LPS do tipo liso se organiza criando uma estrutura em forma de escudo que impede o reconhecimento de ligantes na superfícia bacteriana via TLR2 (ZAMBONI et al., 2004; SHANNON; HOWE; HEINZEN, 2005).

C. burnetii é uma bactéria intracelular com sistema de secreção do tipo IVB ativo, com capacidade de estabelecer um nicho replicativo e multiplicar no interior de macrófagos. Por essa razão, é razoável especular que $C$. burnetii possa ainda subverter respostas imunes que incluam o reconhecimento por outra classe de PRRs da imunidade inata, como os receptores citoplasmáticos do tipo Nod (NLRs, do inglês Nucleotide-binding domain leucine-rich repeatcontaining protein receptors). Esses receptores também são capazes de reconhecer MAMPs e DAMPs e montam resposta por meio da ativação dos inflamassomas, que são grandes complexos proteicos que processam e ativam proteínas caspases e citocinas pró-inflamatórias (TING; WILLINGHAM; BERGSTRALH, 2008; GUO; CALLAWAY; TING, 2015). Já foi descrito por nosso grupo de pesquisa a participação do efetor bacteriano IcaA (do inglês, Inhibition of caspase Activation), na inibição da ativação de caspase-11 e suas funções, incluindo formação de poros e ativação não-canônica do inflamassoma (CUNHA et al., 2015). 
No entanto, ainda são necessárias mais investigações do possível papel dos inflamassomas na resposta à infecção por C. burnetii.

O desenvolvimento e aprimoramento do cultivo da bactéria em meio axênico permitiu o avanço das metodologias de manipulação genética de C. burnetii (OMSLAND et al., 2009; OMSLAND et al., 2011). Dessa forma, possibilitou-se a identificação de novos efetores bacterianos envolvidos em processos como biogênese e manutenção do vacúolo parasitóforo e subversão da resposta imune do hospedeiro. A identificação do efetor IcaA e a caracterização do seu papel na subversão da resposta imune do hospedeiro por nosso grupo de pesquisa, por exemplo, só foi possível graças à utilização do cultivo em meio axênico para criação da bactéria mutante para IcaA, reforçando a importância do desenvolvimento dessas técnicas. Futuramente, essas técnicas auxiliarão ainda mais no entendimento das relações patógenohospedeiro envolvendo infecções com essa bactéria (CAREY et al., 2011; NEWTON et al., 2014; KOHLER et al., 2016; LATOMANSKI et al., 2016; CRABILL et al., 2018).

\subsection{Polarização de macrófagos e monócitos em resposta à Coxiella burnetii}

Um aspecto importante envolvendo a resposta imune do hospedeiro à infecção por $C$. burnetii diz respeito ao estado de polarização induzido pela bactéria em monócitos e macrófagos, suas principais células-alvo. Ambos os tipos celulares participam de diversos processos nos organismos como desenvolvimento e homeostase de tecidos, reparação tecidual, fagocitose de patógenos e células mortas, inflamação e outros aspectos da resposta imune (MANTOVANI et al., 2002; MANTOVANI et al., 2004; WYNN; CHAWLA; POLLARD, 2013). A habilidade dessas células em desempenhar tantas funções distintas reside na grande heterogeneidade e plasticidade que apresentam. De forma geral, diz-se que a polarização dos macrófagos e monócitos refere-se a um estado de ativação especializado adquirido em um determinado local dentro de uma janela temporal específica, em resposta a sinais endógenos e exógenos. Esses sinais podem ser citocinas, produtos microbianos, sinais de perigo, sinais homeostáticos, fatores de crescimento, entre outros. Depois de ativadas, as células desempenham funções especializadas (MANTOVANI; SICA; LOCATI, 2005; MARTINEZ; GORDON, 2014; GLASS; NATOLI, 2016; MURRAY, 2017).

O conceito de ativação clássica dos macrófagos surgiu a partir dos trabalhos sobre resistência celular à infecção realizados por Mackaness (1962). Nesses trabalhos foi demonstrado aumento da atividade microbicida de macrófagos dependente de antígenos

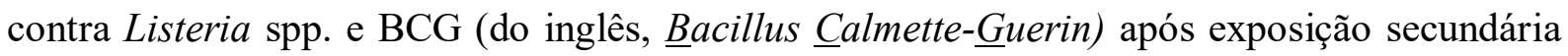


aos patógenos. Esse aumento foi posteriormente relacionado à produção de IFN- $\gamma$ e respostas do tipo Th1 pelas células imunes ativadas pelos antígenos, sendo estendido para propriedades antitumorais e citotóxicas (NATHAN et al., 1983; PACE et al., 1983; CELADA et al., 1984). Posteriormente, outros pesquisadores identificaram macrófagos que apresentavam respostas relacionadas com o padrão Th2 da resposta imune, diferentemente do fenótipo de ativação proposto no modelo clássico de Mackaness (1962). Como resposta padrão Th2, os macrófagos apresentaram secreção reduzida de citocinas pró-inflamatórias, proteção extracelular de parasitas e alta expressão de MHC-II (STEIN et al., 1992; DOYLE et al., 1994). Considerando observações, juntamente com a descoberta de uma capacidade de resposta diferencial a estímulos clássicos como IFN- $\gamma$, LPS ou ambos e diferenças metabólicas entre macrófagos ativados em camundongos com backgrounds Th1 ou Th2, Mills e colaboradores (2000) criaram os termos "M1" e "M2" para se referir a macrófagos ativados de forma "clássica" ou "alternativa", respectivamente. Ao macrófago näive, diferenciado, mas não ativado, foi designado o termo "M0" (MILLS et al., 2000; MARTINEZ; GORDON, 2014; MURRAY, 2017).

Durante muitos anos essa classificação dualística foi mantida para se referir aos estados de ativação e polarização dos macrófagos. No entanto, o avanço dos estudos na área e o aprimoramento das técnicas de análise mostraram a existência de outros fenótipos de polarização dos macrófagos que não se enquadravam perfeitamente no modelo existente, como é o caso de IL-10, TGF- $\beta$ e glicocorticoides, reforçando a necessidade de revisá-lo. De fato, a polarização em si é afetada por múltiplos fatores que incluem, por exemplo, a origem do macrófago e o microambiente tecidual e circulante, os quais por si só apresentam uma heterogeneidade grande e dependem inclusive do momento analisado. Sendo assim, a questão da polarização dos macrófagos deve ser vista como multidimensional (GINHOUX et al., 2015; XUE et al., 2014; MURRAY, 2017). Esses fenótipos distintos foram então integrados e subclassificados entre os dois estados funcionais polarizados que já existiam, sendo a classificação dependente do efeito que causavam em marcadores de macrófagos selecionados. Dessa forma, manteve-se o estado M1 e subdividiu-se o M2 nos estados: a) M2a, induzido por IL-4 e IL-13; b) M2b, induzido por imunocomplexos, receptores Fc, agonistas de TLRs e agonistas de IL-1R; c) M2c, induzido por IL-10 e glicocorticoides e comum para humanos e camundongos (Figura 3); e d) M2d, induzido por agonistas de TLRs via receptor de adenosina, relacionado a macrófagos associados a tumores e exclusivo para camundongos 
(MANTOVANI et al., 2004; DULUC et al., 2007; MARTINEZ et al., 2008; MARTINEZ; GORDON, 2014; MURRAY, 2017; SHAPOURI-MOGHADDAM et al., 2018).
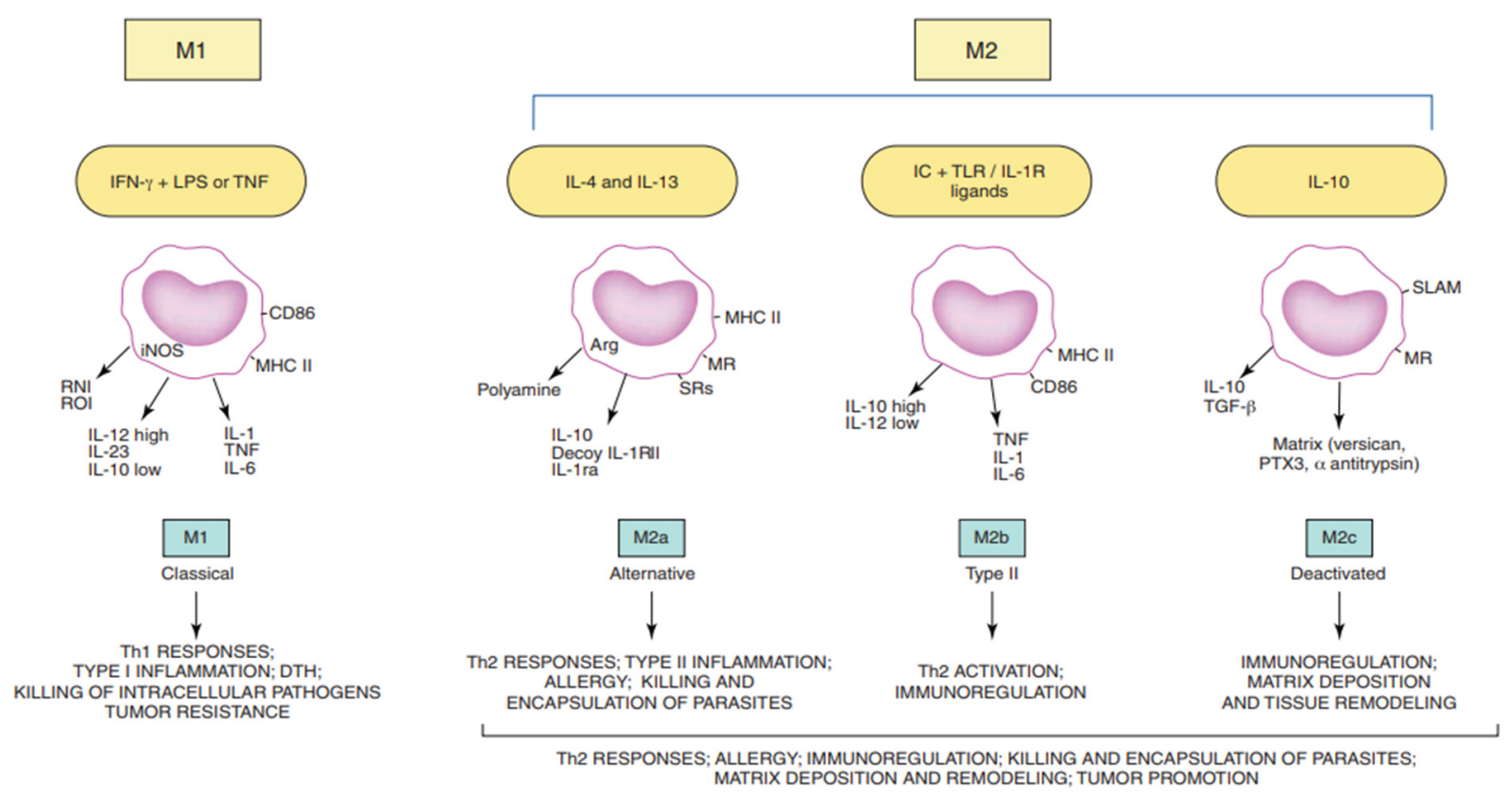

Figura 3 - Representação do modelo de polarização de macrófagos com os estados comuns para humanos e camundongos. Macrófagos apresentam fenótipos distintos de polarização dependendo do estímulo recebido, os quais podem induzir um estado M1 (induzido por IFN $\gamma+$ LPS ou TNF) ou um estado M2. O estado M2 subdivide-se em M2a (induzido por IL-4 e IL-13), M2b (induzido por imunocomplexos + ligantes de TLR/IL1R) e M2c (induzido por IL-10 e glicocorticóides). Em camundongos, ocorre ainda a polarização em um estado M2d (induzido por agonistas de TLRs via receptor de adenosina), não representado na imagem acima. Cada estado de polarização vai desencadear ações efetoras específicas, refletindo assim a plasticidade e a heterogeneidade observada entre macrófagos. Adaptado de: Mantovani e colaboradores (2004).

De forma geral, macrófagos classicamente ativados, ou M1, participam funcionalmente de respostas pró-inflamatórias, anti-tumorais e antimicrobianas, participando da eliminação de patógenos por meio da ativação do sistema de NADPH oxidase (do inglês,

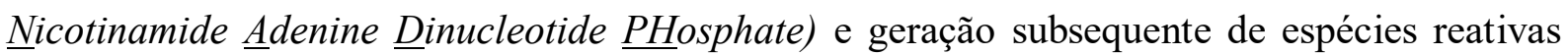
de oxigênio (ROS), além da geração de espécies reativas de nitrogênio (RNS). Devido ao alto nível de ROS que produzem, esses macrófagos direcionam a indução de danos teciduais e prejudicam a regeneração de tecidos, ocasionalmente levando ao desenvolvimento de quadros de inflamação crônica. A indução desse estado de ativação ocorre tipicamente por citocinas Th1, como IFN- $\gamma$ e TNF- $\alpha$, ou pelo reconhecimento de LPS bacteriano, levando à produção e 
secreção de altos níveis de citocinas pró-inflamatórias como TNF- $\alpha$, IL-1 $\alpha$, IL-1 $\beta$, IL-6, IL12, IL-23 e ciclooxigenase-2 (COX-2) e baixos níveis de IL-10. Além disso, a expressão elevada de genes como Nos2, Tnf, Ifn e Tlr2 são considerados alguns dos marcadores de polarização M1 (MANTOVANI et al., 2004; BISWAS et al., 2012; LOCATI; MANTOVANI; SICA, 2013; MURRAY et al., 2014; MURRAY, 2017; SHAPOURIMOGHADDAM et al., 2018).

Os macrófagos alternativamente ativados, ou M2, apresentam de forma geral respostas padrão Th2 com características anti-inflamatórias, desempenhando funções relacionadas com a manutenção da homeostase, apresentando alta capacidade de fagocitose, propriedades prófibróticas e pró-angiogênicas, promovendo reparo celular e cicatrização, imunoregulação, remodelamento tecidual, beneficiando a formação e progressão de tumores e a eliminação e encapsulamento de parasitas. A indução do estado M2 se dá principalmente pela ação das citocinas IL-4 e IL-13 via ativação de STAT6 por meio do receptor IL-4R $\alpha$. No entanto, as citocinas IL-10, IL-33 e IL-21 também podem induzir esse estado de polarização por meio de outras vias. Macrófagos M2 produzem quantidades pequenas de IL-12 e quantidades altas de IL-10 e TGF- $\beta$, além da expressão elevada de genes como ArginaseI, Fizz1, Ym1, Il-4, receptores de manose são considerados alguns dos marcadores desse padrão de polarização (GORDON, 2003; MANTOVANI et al., 2013; MURRAY, 2017; SHAPOURIMOGHADDAM 2018).

Ainda não está bem estabelecido qual o fator mais importante para a determinação do estado de polarização e, consequentemente, para as funções especializadas desempenhadas por macrófagos: a ontogenia ou o a plasticidade, representada pelo efeito do microambiente tecidual. Essa questão é de extrema importância, visto que pode auxiliar no entendimento de como as células se comportam em estados de homeostase ou não, como no caso de inflamações e infecções por patógenos, e assim buscar estratégias de intervenção. Está bem elucidado que macrófagos possuem duas fontes de origem, sendo elas os progenitores embrionários e a medula óssea. Ambos apresentam capacidade de proliferação sob ação de estímulos apropriados e desempenham funções específicas, essenciais para garantia da manutenção da homeostase do organismo (LAVIN et al., 2015; PERDIGUERO; GEISSMANN, 2015; GINHOUX et al., 2016; MURRAY, 2017; BONNARDEL; GUILLIAMS, 2018).

Os tecidos apresentam uma população de macrófagos com origem mista, sendo que nesses locais é possível observar a presença de macrófagos residentes, geralmente 
terminalmente diferenciados, e também de precursores recrutados. Sendo assim, cientistas têm investigado se a ativação e polarização desses macrófagos dependem de sua origem ou do microambiente tecidual em que estão inseridos. Caso dependam da origem, as células responderiam de forma diferente caso tenham derivado de precursores embrionários ou da medula óssea mesmo frente aos mesmos estímulos do microambiente tecidual. No outro caso, independentemente da origem, o que determinaria o estado de polarização seria $o$ microambiente tecidual (incluindo aqui citocinas, quimiocinas, fatores de sobrevivência e outros) em um determinado espaço e tempo, ou seja, sua grande plasticidade (Figura 4) (MURRAY, 2017; BONNARDEL; GUILLIAMS, 2018). Apesar de ambas as hipóteses apresentarem evidências que as suportam, há uma terceira hipótese que as combina. Nela, o microambiente tecidual em um determinado local dentro de uma janela temporal específica seria essencial para direcionar os macrófagos para um determinado estado de polarização, no qual a amplitude da resposta apresentada variaria dependendo da origem daquela célula. 

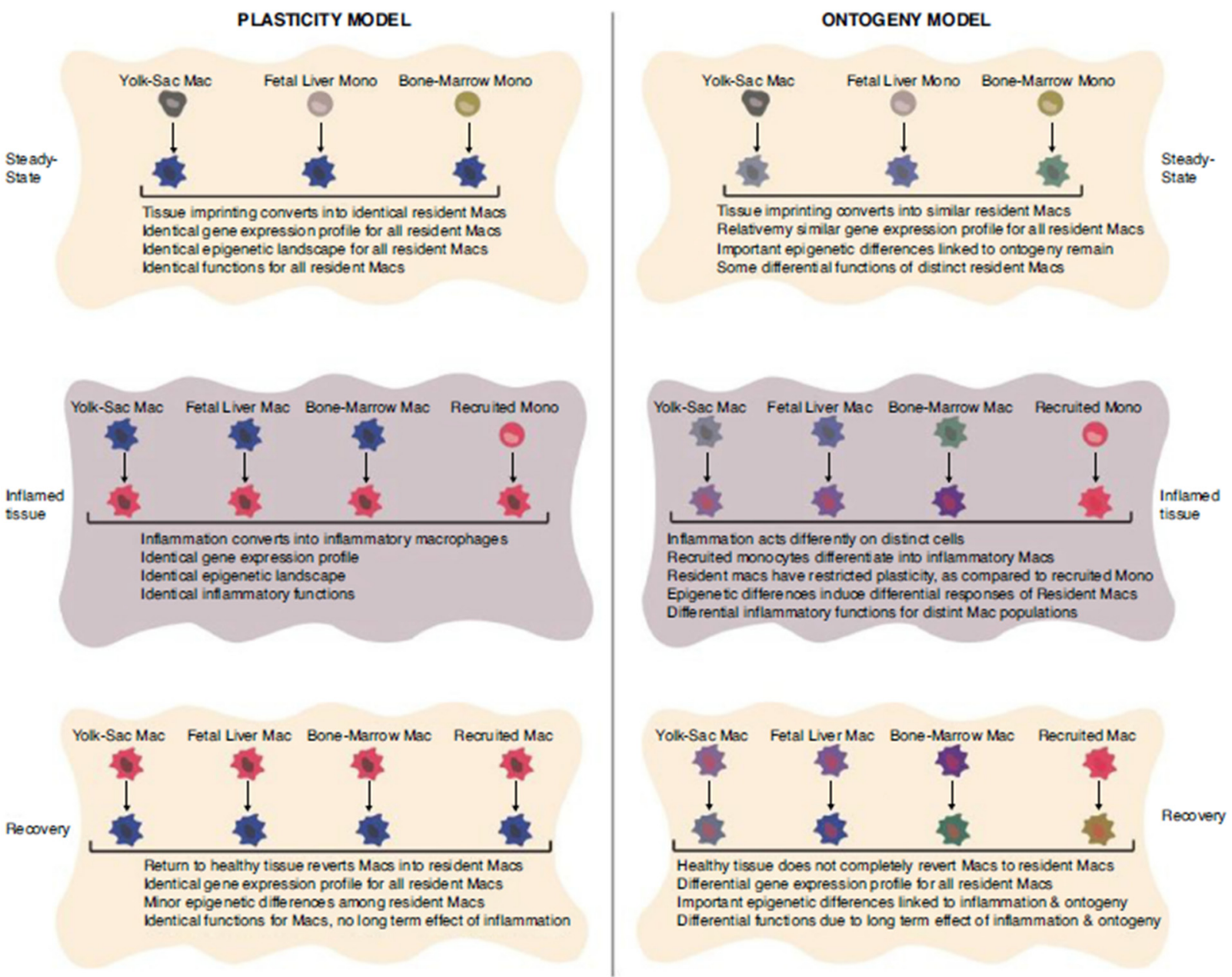

Figura 4 - Representação dos modelos de plasticidade e ontogenia na determinação do estado de polarização dos macrófagos. Segundo o modelo da plasticidade, a população de macrófagos em um determinado local seria relativamente homogênea, pois os estímulos fornecidos pelo microambiente seriam prevalentes para definição do estado de polarização, independentemente da origem apresentada. Nesse modelo, após o término dos estímulos (por exemplo, a resolução de um cenário de inflamação) a população de macrófagos retornaria a um estado homogêneo de macrófagos residentes, com perfil de expressão gênica idêntico e sem grandes alterações epigenéticas. Já segundo o modelo que considera a ontogenia como fator prevalente, macrófagos residentes que apresentam uma mesma origem teriam padrões similares de expressão gênica entre si, com prevalência de diferenças epigenéticas próprias à cada origem, resultando em uma população heterogênea de células. Frente a um estímulo como um cenário de inflamação, os macrófagos responderiam de forma diferente de acordo com sua origem. Após o término do estímulo, os macrófagos restantes apresentariam diferentes perfis de expressão gênica e acumulariam novas diferenças epigenéticas, resultando cada vez mais em populações heterogêneas. Adaptado de Bonnardel e Guilliams (2018). 
No contexto das infecções por C. burnetii, foi observado que o padrão de polarização induzido varia de acordo com o tipo celular infectado (macrófago ou monócito). Para os monócitos, a infecção com C. burnetii resulta em polarização no padrão $\mathrm{M} 1$, desencadeando uma forte resposta pró-inflamatória e microbicida do tipo Th1, com produção de grandes quantidades de IFN- $\gamma$. De fato, IFN- $\gamma$ parece ser fundamental na resposta microbicida à bactéria, visto que macrófagos deficientes para o gene de IFN- $\gamma$ mostram-se mais suscetíveis à replicação (ANDOH et al., 2007; DELLACASAGRANDE et al., 1999). A atividade microbicida induzida por IFN- $\gamma$ é independente de oxigênio e, em modelos murinos, está relacionada com a produção de RNS (YOSHIIE et al., 1999; ZAMBONI; RABINOVITCH, 2003; BRENNAN et al., 2004; ZAMBONI; RABINOVITCH, 2004). Dentre as respostas microbicidas induzidas por IFN- $\gamma$ e independentes de oxigênio encontram-se a capacidade de alterar o $\mathrm{pH}$ dos fagossomos contendo $C$. burnetii através da interferência com processo de fusão entre os fagossomos e os lisossomos, a habilidade de controlar o metabolismo de ferro por meio de redução na quantidade de receptores de transferina (levando à redução da carga bacteriana), e a promoção da apoptose das células infectadas de forma dependente de TNF (DELLACASAGRANDE et al., 1999; HOWE; MALLAVIA, 1999; GHIGO et al., 2002; CAPO; MEGE, 2012).

Diferentemente, em macrófagos foi observado que C. burnetii induz um programa atípico de polarização em um estado M2. O mesmo é caracterizado pela expressão elevada de genes que codificam para IL-10, IL-1ra, TGF- $\beta$, Arginase-1 e receptores de manose, bem como diminuição dos níveis de expressão dos genes que codificam para TNF- $\alpha$ e TLR2, marcadores típicos de padrão M1 (BENOIT et al., 2008). Por seu forte papel imunomodulador, essa produção elevada de IL-10 induzida pela bactéria compreende um dos principais mecanismos relacionados com a persistência da infecção, levando à evolução da doença para cenários de infecção crônica (GHIGO et al., 2004; AMARA; BECHAH; MEGE, 2012; MEGHARI et al., 2006; CAPO; MEGE, 2012; ELDIN, 2017). Dessa forma, o tipo de padrão de polarização adquirido em resposta à infecção por C. burnetii é um processo fundamental para o desencadeamento de respostas, podendo tanto levar ao controle da infecção quanto à persistência da bactéria no hospedeiro e desenvolvimento da forma crônica da doença. Sendo assim, a interferência com o padrão de polarização dos macrófagos pode compreender um alvo terapêutico para o controle das infecções por C. burnetii. 


\subsection{Modelos de estudo das interações patógeno-hospedeiro com infecção por Coxiella burnetii}

Apesar da diferença nos tipos de LPS, o tráfego intracelular e a cinética de crescimento das formas virulentas e avirulentas de C. burnetii em macrófagos humanos é indistinguível. Além disso, macrófagos humanos são capazes de restringir igualmente a multiplicação tanto da fase I quanto da fase II, portanto ambas as variantes podem ser utilizadas em estudos para avaliação das relações patógeno-hospedeiro. Em adição, há um clone da cepa Nine Mile fase II que apresenta uma grande deleção cromossomal que o torna incapaz de retornar ao estado completo de virulência, tornando-o apropriado para uso em condições de biossegurança nível 2 (AMANO; WILLIAMS, 1984; HACKSTADT, 1996; HOWE et al., 2010; GRAHAM et al., 2013; LARSON et al., 2016).

Embora C. burnetii seja altamente adaptada à sobrevivência nas células do hospedeiro, subvertendo e evadindo as respostas imunes por meio da ação de seus efetores bacterianos e manipulação de diferentes vias de sinalização, existem hospedeiros imunocompetentes que conseguem controlar sua multiplicação (ZAMBONI, 2004). Portanto, existem respostas efetivas contra C. burnetii. Como demonstrado anteriormente, macrófagos de origens distintas diferem quanto à suscetibilidade à replicação intracelular de C. burnetii. Macrófagos derivados de medula óssea e macrófagos peritoneais primários se mostraram intrinsecamente mais restritivos (ZAMBONI et al., 2002; ZAMBONI; RABINOVITCH, 2003). Essas observações sugerem que a suscetibilidade dos macrófagos à infecção por C. burnetii possa estar relacionada com a origem celular, mais do que com o microambiente em que se encontram. Além disso, macrófagos derivados da medula óssea de camundongos da linhagem C57BL/6 são capazes de controlar o crescimento da bactéria fase II, enquanto macrófagos derivados da medula óssea de camundongos das linhagens $\mathrm{A} / \mathrm{J}$ e $\mathrm{BALB} / \mathrm{c}$ são mais suscetíveis, demonstrando que diferentes linhagens de camundongos também apresentam diferenças na suscetibilidade à bactéria (ZAMBONI, 2004; ZAMBONI; RABINOVITCH, 2004). O mesmo foi observado para estudos envolvendo a infecção de camundongos das linhagens $\mathrm{C} 57 \mathrm{BL} / 6$ e A/J frente à infecção por $C$. burnetii fase $\mathrm{I}$, com os primeiros se mostrando mais restritivos, levantando a possibilidade de que a suscetibilidade à $C$. burnetii esteja relacionada com alguma característica inerente ao fundo gênico do camundongo (SCOTT; WILLIAMS; STEPHENSON, 1987). No entanto, ao analisar macrófagos peritoneais provenientes de camundongos $\mathrm{BALB} / \mathrm{c}$, verificou-se que os mesmos apresentaram 
a capacidade de controlar parcialmente a infecção por C. burnetii fase II (ZAMBONI et al., 2002).

Além de macrófagos peritoneais e macrófagos derivados de medula óssea, macrófagos alveolares compreendem outro importante modelo de infecção com C. burnetii utilizado para estudos sobre a interação entre a bactéria e o hospedeiro. Os macrófagos alveolares têm sido considerados por muito tempo como sítio primário da infecção por esse patógeno (KHAVIN; TABIBZADEH, 1988). Estudos realizados com macrófagos alveolares isolados de tecidos post-mortem de seres humanos apresentaram capacidade de suportar a replicação de diferentes patótipos de C. burnetii (GRAHAM et al., 2013). Interessantemente, macrófagos alveolares derivados de macacos demonstraram forte atividade anti-apoptótica associada com infecções por C. burnetii (VOTH; HOWE; HEINZEN, 2007). Já em modelos murinos, foi demonstrado que macrófagos alveolares produzem óxido nítrico em resposta à infecção (YOSHIIE et al., 1999) e são suscetíveis à replicação do patógeno (CALVERLEY et al., 2012). Nesse contexto, estudos visando o entendimento das relações patógeno-hospedeiro e dos mecanismos pelos quais diferentes fundos gênicos e tipos celulares distintos conseguem controlar o crescimento intracelular de $C$. burnetii permanecem de extrema relevância e continuam a suscitar grande interesse científico. Para isso, é necessário o desenvolvimento de novos modelos de estudo apropriados como ferramenta fundamental para os avanços nessa área. 


\section{OBJETIVOS}

\subsection{Objetivo Geral}

Avaliar a suscetibilidade de macrófagos alveolares murinos à infecção por $C$. burnetii fase II in vitro a fim de estabelecer um modelo de célula primária que seja fisiologicamente relevante para estudos de interação patógeno-hospedeiro com essa bactéria.

\subsection{Objetivos Específicos}

- Avaliar a resposta de macrófagos derivados de medula óssea e de macrófagos alveolares à infecção por C. burnetii.

- Analisar a suscetibilidade de macrófagos alveolares à infecção por C. burnetii através de técnicas de microscopia.

- Identificar os possíveis mecanismos envolvidos na suscetibilidade de macrófagos alveolares à infecção por C. burnetii.

- Analisar a suscetibidade à infecção por C. burnetii de macrófagos alveolares deficientes em componentes importantes para resposta imune contra esse patógeno.

- Comparar a suscetibilidade de macrófagos alveolares murinos à infecção por C. burnetii com outros modelos celulares suscetíveis já descritos. 


\section{MATERIAIS E MÉTODOS}

\subsection{Animais}

Foram utilizados camundongos adultos (seis a oito semanas) das linhagens A/J, C57BL/6, bem como nocautes para Nos2, Ifny e Il-4 com fundo genético de camundongos C57BL/6. Os animais foram mantidos no Biotério do Departamento de Biologia Celular e Molecular e Bioagentes Patogênicos e no Biotério do Departamento de Imunologia e Bioquímica. Foram providenciadas água e comida à vontade para todos os animais.

\subsection{Obtenção e preparo de $C$. burnetii para infecção}

Inóculos de Coxiella burnetii da linhagem Nine Mile fase II (RSA493) foram preparados a partir de monocamadas de células Vero infectadas, conforme descrito por Zamboni; Mortara e Rabinovitch (2001). Culturas confluentes de células Vero foram irradiadas com 10 Gy $60 \mathrm{Co}$ para bloquear a divisão celular e mantidas a $37^{\circ} \mathrm{C}$ e $5 \%$ de $\mathrm{CO}_{2}$ em meio DMEM (do inglês, Dulbecco's Modified Eagle's Medium) (Gibco - Thermo Fischer) com 10\% de soro fetal bovino (SBF) (Gibco - Thermo Fischer) e 1mM L-glutamina (Sigma-Aldrich). As células Vero foram infectadas com Coxiella e mantidas nas condições acima por mais seis dias. Para o preparo dos inóculos, as células Vero infectadas foram lisadas por homogeneização em água destilada estéril. O lisado celular foi centrifugado a 1.810 x $g$ por 10 minutos a $4^{\circ} \mathrm{C}$. O sobrenadante foi descartado e o pellet ressuspendido em

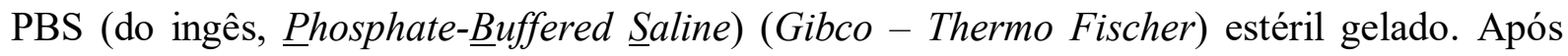
nova centrifugação a 12.857 x $g$ por 30 minutos a $4^{\circ} \mathrm{C}$, o sobrenadante foi novamente descartado e o pellet ressuspendido em RPMI 1640 + HEPES (Gibco - Thermo Fischer) com $10 \% \mathrm{SBF}$, submetido à sonicação a $35 \mathrm{kHz}$ durante três minutos, aliquotado e mantido a temperatura de $-80^{\circ} \mathrm{C}$. Para a realização dos experimentos, as alíquotas foram descongeladas em banho a $37^{\circ} \mathrm{C}$ e submetidas à sonicação a $35 \mathrm{kHz}$ por três minutos.

\subsection{Cultura de células de linhagem de mamíferos}

Células THP-1 foram cultivadas em meio RPMI 1640 + HEPES suplementado com 10\% SBF, e células Vero foram mantidas em meio DMEM com 10\% SBF e 1mM L- 
glutamina a $37^{\circ} \mathrm{C}$ em $5 \% \mathrm{CO}_{2}$. Para experimentos com células THP-1, a diferenciação em células do tipo macrófago foram mediadas pela adição de 200nM de forbol 12-miristato 13acetato (PMA) na cultura, como descrito por Voth; Howe e Heinzen (2007). Após dozequatorze horas, o meio foi substituído por meio sem PMA para a realização das infecções. Para infecção das células Vero, as células foram irradiadas com 10 Gy 60Co e mantidas durante doze-quatorze horas a $37^{\circ} \mathrm{C}$ em $5 \% \mathrm{CO}_{2}$ antes da infecção.

\subsection{Preparo de macrófagos derivados de medula óssea (BMDMs)}

Macrófagos derivados de medula óssea foram diferenciados in vitro a partir de células tronco extraídas do fêmur de camundongos adultos (seis a oito semanas) das linhagens citadas anteriormente, segundo protocolo descrito por Marim e colaboradores (2010). Brevemente, células da medula óssea foram coletadas dos fềmures e diferenciadas por sete dias em estufa a $37^{\circ} \mathrm{C}, 5 \% \mathrm{CO}_{2}$ em meio RPMI $1640+$ HEPES suplementado com $20 \%$ de SBF, $30 \%$ de meio condicionado por células L929 (LCCM), fonte de M-CSF (fator importante para diferenciação de células progenitoras em macrófagos), e 100U/mL de penicilina/estreptomicina (SigmaAldrich). Após a diferenciação, os macrófagos foram coletados pela lavagem das monocamadas com PBS gelado, centrifugados a $200 \mathrm{x} g$ por cinco minutos a $4^{\circ} \mathrm{C}$ e o sobrenadante descartado. O pellet foi ressuspendido em meio RPMI 1640 + HEPES contendo $10 \%$ SBF e $5 \%$ de LCCM e as células foram quantificadas com auxílio de uma câmara de Neubauer. Os macrófagos foram plaqueados a uma densidade de $10^{5}$ células/poço em placas tratadas de 24 poços um dia antes da infecção e mantidos em cultura em meio RPMI $1640+$ HEPES, contendo $10 \%$ SBF e 5\% de LCCM.

\subsection{Preparo de macrófagos alveolares (AMs)}

Macrófagos alveolares foram obtidos de camundongos adultos (seis a oito semanas) através de lavagem brônquio-alveolar (BAL). Os animais foram eutanasiados por dose excessiva de anestésico com injeção intravenosa de cetamina e xilazina a $50 \mathrm{mg} / \mathrm{kg}$ e 10 $\mathrm{mg} / \mathrm{kg}$, respectivamente. Posteriormente, a traqueia dos camundongos foi perfurada com cânula estéril (BD AngioCath) e os pulmões foram lavados quatro vezes consecutivas com 1

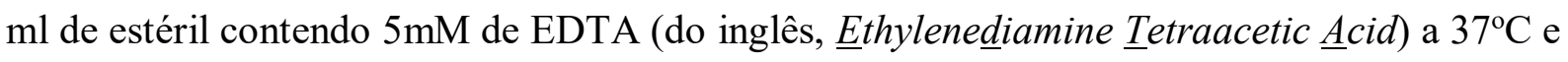
o material coletado foi depositado em um tubo cônico tipo falcon estéril. As células obtidas 
foram transferidas para um novo falcon e lavadas duas vezes em PBS estéril, com centrifugações a $200 \mathrm{x} g$ durante 10 minutos a $4^{\circ} \mathrm{C}$. O sobrenadante foi descartado e o pellet ressuspendido em meio RPMI 1640 + HEPES com 10\% SBF, 1mM L-glutamina e 100U/ml penicilina/estreptomicina. As células foram quantificadas com auxílio de uma câmara de Neubauer e plaqueadas na densidade de $10^{5}$ células/poço em placas de 24 poços. Os macrófagos foram mantidos em cultura em meio RPMI 1640 + HEPES com 10\% SBF, 1mM L-glutamina e $100 \mathrm{U} / \mathrm{ml}$ penicilina/estreptomicina, a uma temperatura de $37^{\circ} \mathrm{C}$ e $5 \% \mathrm{CO}_{2} \mathrm{O}$ meio de cultura foi substituído duas vezes antes da infecção por meio sem antibiótico. Meio fresco foi adicionado às culturas após seis dias de infecção.

\subsection{Infecção com Coxiella burnetii}

Para infecção das culturas celulares, alíquotas de C. burnetii foram descongeladas em banho a $37^{\circ} \mathrm{C}$ e submetidas à sonicação a $35 \mathrm{kHz}$ por três minutos para dissolução de aglomerados de bactéria. $\mathrm{O}$ meio presente nas placas com as células em cultivo foi aspirado e substituído por meio fresco antes da infecção. As bactérias foram homogeneizadas com pipeta e inoculadas diretamente nas placas com as células em cultura, com multiplicidade de infecção (MOI) de 3 ou 100. As placas foram centrifugadas a 200 x $g$ por cinco minutos a $25^{\circ} \mathrm{C}$ e colocadas em estufa a $37^{\circ} \mathrm{C}$ e $5 \%$ de $\mathrm{CO}_{2}$. Após um período de infecção de quatro horas o meio de cultura foi aspirado, os poços lavados com PBS estéril morno e o PBS substituído novamente por meio de cultura fresco. Como um controle experimental interno para replicação de C. burnetii, um grupo de células infectadas foi tratado com $20 \mathrm{ug} / \mathrm{ml}$ de rifampicina (RIF) para inibir a tradução proteica de C. burnetii (BRENNAN; SAMUEL, 2003).

\subsection{Microscopia de Fluorescência}

AMs de camundongos C57BL/6 foram plaqueados em uma densidade de $10^{5}$ células por poço, em uma placa de 24 poços contendo lamínulas de vidro de $13 \mathrm{~mm}$. As células foram infectadas com C. burnetii selvagem ou C. burnetii expressando mCherry em um MOI de 3, como descrito anteriormente (CUNHA et al., 2015). Após quatro horas, três dias, seis dias, nove dias ou 13 dias de infecção, as células foram fixadas com 3,5\% de PFA (do inglês, 
Paraformaldehyde) contendo $7,5 \%$ de sacarose por 20 minutos e então lavadas duas vezes com PBS em temperatura ambiente. Para os ensaios com C. burnetii selvagem, as células foram então permeabilizadas por dois minutos com metanol 100\% gelado, seguido por mais duas lavagens com PBS. A autofluorescência celular foi removida por meio de incubação com glicina $0.1 \mathrm{M}$ diluída em PBS por 10 minutos, e então as amostras foram bloqueadas por 30 minutos em temperatura ambiente utilizando PBS contendo $1 \%$ de albumina de soro bovino (BSA - Sigma-Aldrich) e 5\% de soro de cabra. As células foram incubadas com os anticorpos primários anti- C. burnetii (diluição 1:100) feito em coelho e anti-LAMP-1 (diluição 1:2) feito em rato, diluídos em PBS contendo 1\% de BSA por uma hora, posteriormente foram lavadas duas vezes com PBS em temperatura ambiente e então incubadas por 30 minutos em PBS com 1\% BSA contendo os anticorpos secundários conjugados com o fluoróforo Alexa Fluor 488 e Alexa Fluor 594 (Molecular probes - Thermo Fisher Scientific) em uma diluição de 1:2000. Após três lavagens com PBS a temperatura ambiente, as células foram montadas utilizando Prolong Gold Antifade Reagent contendo DAPI (Molecular probes - Thermo Fisher Scientific). Para os experimentos utilizando a C. burnetii expressando mCherry, as células foram lavadas duas vezes com PBS em temperatura ambiente após a fixação e então montadas diretamente com Prolong Gold Antifade Reagent contendo DAPI. Imagens de microscopia multifóton foram adquiridas utilizando um microscópio LSM 780 Zeiss AxioObserver, equipado com uma lente objetiva de imersão à óleo de $63 \mathrm{X}$ de aumento e analisadas utilizando o programa ImageJ.

\subsection{Microscopia Eletrônica de Transmissão}

AMs foram infectados por três ou seis dias, lavados uma vez com PBS, fixados por uma hora em temperatura ambiente com fixador de Karnovsky modificado ( $2 \%$ formaldeído, 2,5\% glutaraldeído em $0,1 \mathrm{M}$ de cacodilato de sódio, $\mathrm{pH}$ 7.4), soltos e então processados para e analisados por microscopia eletrônica de transmissão, conforme descrito por Zamboni e colaboradores (2002). 


\subsection{Quantificação de Coxiella burnetii in vitro}

BMDMs, AMs, células THP-1 e células Vero irradiadas, infectadas com C. burnetii, foram mantidas em cultura a $37^{\circ} \mathrm{C}$, em uma atmosfera contendo $5 \%$ de $\mathrm{CO}_{2}$, por até 12 dias. Após seis dias de infecção, as células foram suplementadas com um adicional de 500ul de meio RPMI 1640 + HEPES contendo $10 \%$ de SFB e 5\% de LCCM para BMDMs, meio RPMI 1640 + HEPES com 10\% SFB para AMs e células THP-1 e meio DMEM com 10\% SFB e 1mM L-glutamina para células Vero irradiadas. Em diferentes tempos após a infecção, células foram lisadas com $1 \mathrm{ml}$ de água deionizada e os lisados celulares foram combinados com o sobrenadante das culturas de cada poço, garantindo assim que toda bactéria contida no poço fosse contada. O material foi então centrifugado a 14.000 x $g$ por 15 minutos em uma temperatura de $4^{\circ} \mathrm{C}$ para a deposição das bactérias presentes nas amostras. O DNA de $C$. burnetii foi extraído utilizando o kit Illustra ${ }^{T M}$ Bacteria GenomicPrep (GE Healthcare) e a presença de material genético foi confirmada por espectrometria (absorbância a 260nm). O par de iniciadores dotA-for e dotA-rev (CAREY et al., 2011) foi utilizado para reação de PCR quantitativo (qPCR), um método confiável para quantificação da replicação bacteriana, como demonstrado por Brennan e Samuel (2003) para análises envolvendo C. burnetii. Para realização da reação, foi utilizado o kit Platinum ${ }^{\circledR} S Y B R{ }^{\circledR}$ Green qPCR SuperMix-UDG with $R O X$ (Invitrogen) e as reações de termociclagem foram montadas de acordo com as instruções do fabricante. As amostras foram lidas em um termociclador ABI Prism 7000.

\subsection{Análises de RT-PCR}

Para analises de RT-PCR foi feita a extração de mRNA de culturas de $10^{6} \mathrm{AMs}$ e BMDMs derivados de camundongos C57BL/6, infectados ou não por 12 horas com $C$. burnetii em um MOI de 3, utilizando o reagente TRIzol. Purificação de RNA foi feita utilizando o minikit Illustra ${ }^{T M}$ RNAspin (GE Healthcare), de acordo com as instruções do fabricante, e o material genético foi quantificado usando o espectrofotômetro NanoDrop (Thermo Scientific). A transcriptase reversa ImProm-II (Promega) foi utilizada para obtenção de cDNA. Os ensaios de PCR quantitativa em tempo real foram realizados usando kit Platinum ${ }^{\circledR}$ SYBR ${ }^{\circledR}$ Green $q P C R$ SuperMix-UDG com carboxi-X-rodamina (Invitrogen). Reações de termociclagem foram feitas de acordo com as instruções do fabricante, e as amostras foram lidas em um sistema de PCR em tempo real StepOnePlus (Applied 
Biosystems). A expressão dos genes alvos foi calculada utilizando os valores do ciclo médio do limite $(C T)$ para cada amostra, os quais foram normalizados com relação a aqueles dos genes housekeeping. As sequências dos iniciadores usados para a reação de PCR de transcrição reversa (RT-PCR) são as seguintes: Gapdh-fwd, 5=CATCACCATCTTCCAGGAGCG-3=; Gapdhrev, 5=-ACGGACACATTGGGGGTAGG-3=; Nos2-fwd, $\quad 5=$ =-CGAAACGCTTCSCTTCCAA-3=; $\quad$ Nos2-rev, $\quad 5=$ TGAGCCTATATTGCTGTGGCT-3=; Ifn-fwd, 5=-GCATCTTGGCTTTGCAGCT-3=; Ifnrev, 5=-CCTTTTTGCCCTTGCTGTTG-3=; Tnf-fwd, 5=-TGTGCTCAGAGCTTTCAACAA3=; Tnf-rev, $\quad$ 5=-CTTGATGGTGCATGAGA-3=; $\quad$ Tlr2-fwd, $\quad 5=$ AAGTCTCCGGAATTATCAGTCC-3=; Tlr2-rev, 5=-TGATGGATGTCGCGGAT-3=; Il4fwd, $\quad 5=$-AAGAGCATCATGCAAATGGA-3=; Il4-rev, $\quad 5=$ TTAAAGCATGGTGGCTCAGTAC-3=; $\quad$ Arginasel-fwd, $5=$ GTTCCCAGATGTACCAGGATTC-3=; Arginase 1-rev, $5=$ CGATGTCTTTGGCAGATATGC-3=; Fizzl-fwd， 5=-TGTGGCTTTGCCTGTGGAT-3=; Fizzl-rev, 5=-TCTTAGGACAGTTGGCAGCAG-3=; $\quad Y m 1$-fwd, $\quad$ =GGGTTGGTTATGACAATGTCAG-3=; e Yml-rev, 5=-TGAAGTCATCCATGTCCAGG$3=$.

\subsection{Citometria de fluxo para análises fenotípicas}

Suspensões únicas de AMs e BMDMs de camundongos C57BL/6 foram marcadas com corantes do kit de viabilidade celular LIVE/DEAD fixable blue dead cell stain kit (Invitrogen) em PBS para excluir células mortas da análise. As células foram então coradas com anticorpos conjugados a fluorocromos contra os marcadores de superfície $\mathrm{Cd} 11 \mathrm{~b}$ (clone M1/70), F4/80 (clone BM8), CD206 (clone C068C2) e CD86 (clone GL-1), adquiridos da BD Biosciences (San Diego, CA), e dectina-1/CLEC7 (CD369), obtido da BioLegend, em PBS contendo $1 \%$ de SFB por 30 minutos em $4^{\circ} \mathrm{C}$ e então lavadas. A marcação foi realizada na presença de $5 \mathrm{ug} / \mathrm{ml}$ de $F$ C Block (BD Biosciences). Aquisição de células foi realizada no citômetro de fluxo BD FACSCanto II, utilizando o programa FACSDiva (BD Biosciences). Para cada amostra, pelo menos 100.000 eventos foram coletados. Os dados foram analisados com o programa FlowJo (TreeStar). 


\subsection{2 - Declaração ética}

Os cuidados com os animais neste trabalho foram realizados segundo as diretrizes institucionais de ética em experimentação animal e foram aprovadas pela Comissão de Ética em Experimentação Animal da Faculdade de Medicina de Ribeirão Preto (CETEA - Número de protocolos: 097/2010 e 002/2015). Para a eutanásia, os camundongos foram tratados com cetamina e xilazina ( $50 \mathrm{mg} / \mathrm{kg}$ e $10 \mathrm{mg} / \mathrm{kg}$, respectivamente) por via intravenosa.

\subsection{Análises Estatísticas}

As análises estatísticas foram feitas utilizando-se o programa de análises GraphPad Prism (versão 5). Os resultados foram analisados por aplicação do teste estatístico para análise de variância (ANOVA), seguido de pós-teste Bonferroni ou pós-teste $t$ de Student. As diferenças foram consideradas estatisticamente significativas se o valor $P$ foi $<0,05$. 


\section{RESULTADOS}

\subsection{Macrófagos derivados de medula óssea de camundongos $\mathrm{A} / \mathrm{J}$ são mais suscetíveis à infecção por Coxiella burnetii fase II do que aqueles derivados de camundongos C57BL/6}

C. burnetii apresenta diversos mecanismos de subversão da resposta imune do hospedeiro e, ainda assim, sabe-se que existem hospedeiros imunocompetentes capazes de controlar a replicação da bactéria. Entender de que forma o patógeno interage e manipula as respostas de seu hospedeiro é de grande utilidade para o desenvolvimento de novas estratégias eficientes de combate à infecção por essa bactéria, além de potencialmente elucidar novos mecanismos relacionados com a interação patógeno-hospedeiro e a suscetibilidade a $C$. burnetii. Nesse contexto, é fundamental a determinação e utilização de um modelo de estudo adequado.

Sabe-se que vários tipos de macrófagos murinos têm sido utilizados nos estudos que buscam entender as interações patógeno-hospedeiro que acontecem durante a infecção por $C$. burnetii. Diferenças de suscetibilidade entre macrófagos de linhagens murinas já foram observadas, com macrófagos das linhagens C57BL/6 sendo mais resistentes à infecção do que macrófagos derivados de camundongos A/J e BALB/c (ZAMBONI, 2004; ZAMBONI; RABINOVITCH, 2004). Essa diferença de suscetibilidade descrita por Zamboni (2004) foi observada através da análise quantitativa da formação de vacúolos de C. burnetii, uma das metodologias empregadas em estudos de suscetibilidade às infecções por essa bactéria. Dessa forma, nosso primeiro objetivo foi confirmar essa diferença de suscetibilidade descrita na literatura entre macrófagos derivados de camundongos das linhagens C57BL/6 e A/J quando infectados com C. burnetii fase II. Em adição, optamos por realizar a análise da suscetibilidade através da quantificação do DNA genômico bacteriano por PCR quantitativo (qPCR), uma metodologia confiável para análises envolvendo C. burnetii, como demonstrado por Brennan e Samuel (2003).

Para avaliação da suscetibilidade, BMDMs de camundongos C57BL/6 e A/J foram extraídos e diferenciados segundo protocolo descrito por Marim e colaboradores (2010). Posteriormente, esses macrófagos foram infectados com C. burnetii fase II utilizando-se uma

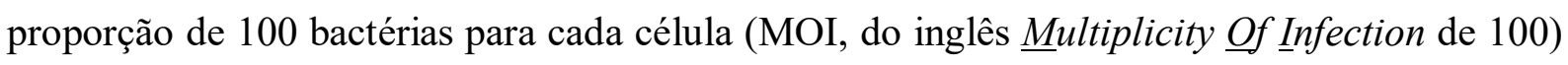
por um período de 12 dias, sendo que a cada três dias um grupo de poços era lisado e 
combinado com seus sobrenadantes para que toda bactéria ali presente fosse coletada. Como controle da entrada da bactéria nas células, poços foram lavados após quatro horas de infecção e lisados, com o material sendo coletado. Um grupo de células infectadas foi ainda tratado com $20 \mu \mathrm{g} / \mathrm{ml}$ de rifampicina (RIF), um inibidor da tradução protéica bacteriana, como controle experimental interno da replicação de C. burnetii (BRENNAN; SAMUEL, 2003). Em seguida, o DNA genômico das amostras coletadas foi extraído, purificado e quantificado por qPCR.

Assim como descrito na literatura, BMDMs derivados de camundongos C57BL/6 mostraram-se restritivos à multiplicação de C. burnetii, controlando a replicação da bactéria e não permitindo um aumento relativo da quantidade de DNA genômico ao longo dos doze dias de infecção. Já BMDMs derivados de camundongos A/J mostraram-se suscetíveis, permitindo por volta de 1,5 $\log$ de crescimento bacteriano nesse mesmo período (Figura 5A). Essa diferença de suscetibilidade observada não foi decorrente de uma entrada diferencial da bactéria nos macrófagos, como pôde ser observado quatro horas após a infecção (5A, excerto em destaque). Para descartar uma possível influência da alta dose infecciosa utilizada (MOI 100) nas diferenças de suscetibilidade observadas entre os BMDMs, repetimos o experimento utilizando um MOI mais baixo, que se assemelha ao que ocorre em infecções naturais (MOI 3). Observamos que BMDMs derivados de camundongos $\mathrm{A} / \mathrm{J}$ são mais suscetíveis à replicação bacteriana do que BMDMs da linhagem C57BL/6. Entretando, diferentemente do que foi observado com MOI mais alto, em infecções realizadas com MOI 3 verificamos que BMDMs C57BL/6 permitiram um pequeno crescimento bacteriano ao longo dos 12 dias de infecção (Figura 5B). Em ambos os casos, o controle experimental interno com rifampicina funcionou, garantindo que de fato o que estava sendo quantificado era a replicação de $C$. burnetii. Esses dados confirmam as diferenças de suscetibilidade descritas na literatura entre as linhagens $\mathrm{C} 57 \mathrm{BL} / 6$ e A/J frente à infecção por C. burnetii fase II, estendendo-as para BMDMs, além de indicar que MOIs mais baixos são mais adequados para esses experimentos. Em adição, os dados obtidos demonstram ainda a relevância do qPCR como ferramenta para análise de suscetibilidade à essa bactéria. 


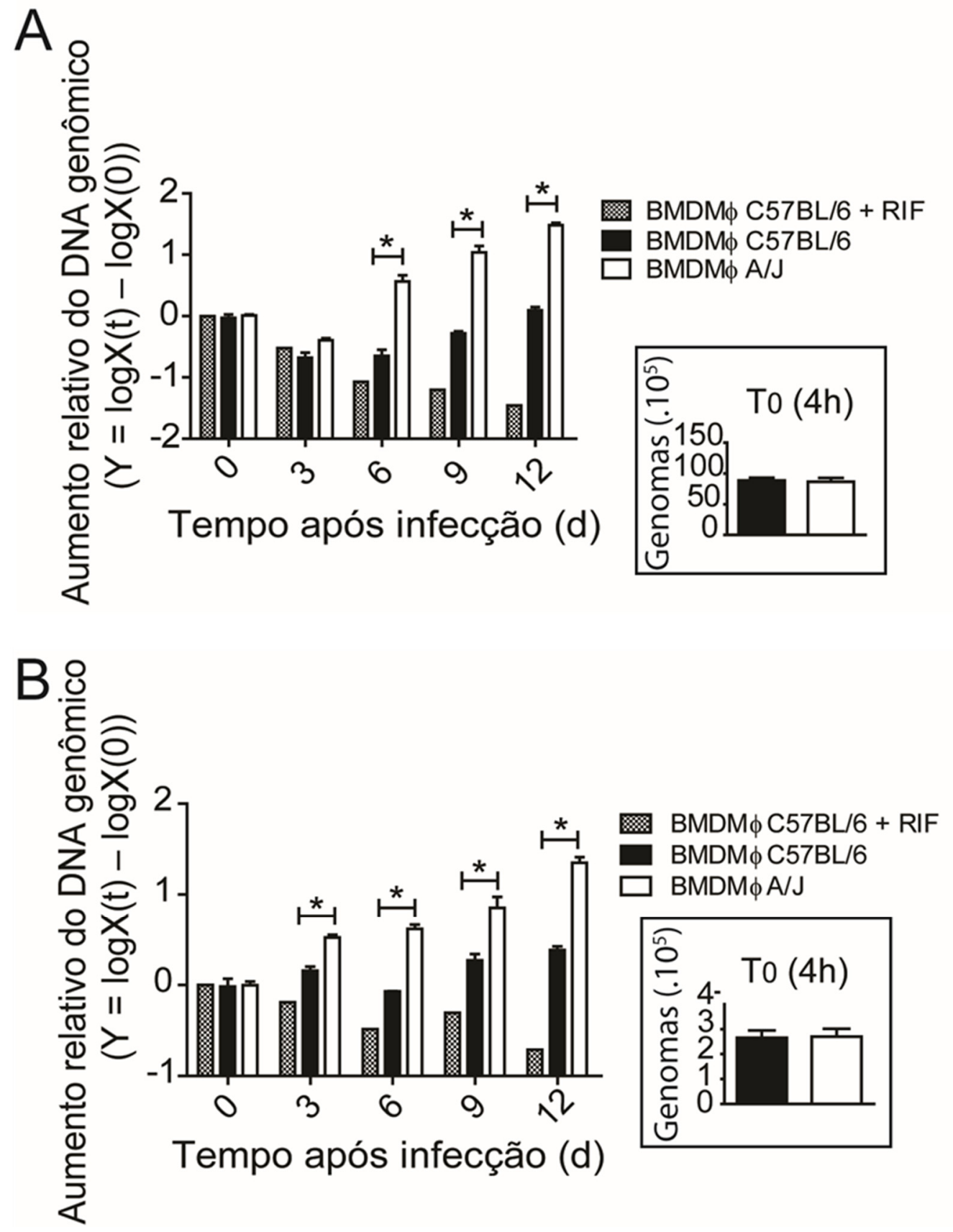

Figura 5 - Macrófagos murinos derivados de medula óssea da linhagem $\mathbf{A} / \mathbf{J}$ são mais suscetíveis à multiplicação de $C$. burnetii fase II do que macrófagos murinos derivados de medula óssea da linhagem C57BL/6. BMDMs das linhagens C57BL/6 e A/J foram infectados com C. burnetii fase II em MOI 100 (A) ou 3 (B) e a multiplicação bacteriana foi avaliada por quantificação do DNA genômico por qPCR após 0 (4 horas após infecção), 3, 6, 9 e 12 dias de infecção. O eixo y representa a diferença logarítmica na base 10 entre a quantificação genômica no tempo X e a quantificação no tempo $0(\log \mathrm{T}(\mathrm{X})-\log \mathrm{T}(0))$. Células tratadas com o inibidor da tradução protéica bacteriana rifampicina (RIF) foram utilizadas como controle negativo da replicação bacteriana. Em destaque, os excertos mostram a quantidade de DNA genômico de C. burnetii 4 horas após a infecção. Barras de erro representam desvio padrão de triplicatas experimentais, e $\left(^{*}\right)$ indica $\mathrm{p}<0,05$; (two-way ANOVA). Os dados são representativos de três réplicas experimentais distintas. Adaptado de: FERNANDES et al (2016). 


\subsection{Macrófagos alveolares derivados de camundongos $\mathrm{C57BL} / 6$ são permissivos à replicação de $C$. burnetii fase II}

Após a confirmação de que BMDMs derivados de camundongos C57BL/6 são restritivos à replicação de $C$. burnetii fase II, nosso próximo objetivo foi identificar um modelo de célula primária murina que permitisse a multiplicação da bactéria in vitro, uma vez que a maioria dos camundongos deficientes para diferentes genes foram gerados no fundo gênico C57BL/6. Levando em consideração o fato de que a infecção por C. burnetii ocorre via aerossol, infectando primariamente monócitos e macrófagos, com os macrófagos alveolares consistindo na célula-alvo primária da bactéria (VOTH; HOWE; HEINZEN, 2007; AMARA; BECHAH; MEGE, 2012), decidimos avaliar se macrófagos alveolares derivados de camundongos C57BL/6 seriam permissivos à replicação de C. burnetii fase II in vitro. Para isso, macrófagos alveolares (AMs) foram obtidos de camundongos C57BL/6 através de lavagem brônquio-alveolar e plaqueados em meio de cultura contendo antibiótico. No dia seguinte as células foram lavadas, o meio substituído por meio sem antibiótico e então foi feita a infecção com C. burnetii fase II em MOI 3. BMDMs derivados de camundongos C57BL/6 também foram utilizados para comparação da suscetibilidade desses dois tipos celulares à replicação bacteriana. Para ambas as células a infecção transcorreu por 12 dias e, novamente, as células foram lisadas e combinadas com seus respectivos sobrenadantes a cada três dias.

Após a extração, purificação e quantificação do DNA genômico bacteriano por qPCR, observamos que surpreendentemente AMs derivados de camundongos C57BL/6 foram altamente permissivos à replicação de $C$. burnetii fase II, permitindo um crescimento de quase três $\operatorname{logs}$ ao longo dos doze dias de infecção, em contraste ao que foi observado anteriormente para BMDMs (Figura 6A). Novamente não houve diferença na entrada da bactéria nesses dois tipos celulares, como observado pela quantificação de DNA genômico após quatro horas de infecção (Figura 6A, excerto em destaque). Em seguida, verificamos se a suscetibilidade observada em AMs da linhagem C57BL/6 também ocorreria em AMs derivados de camundongos $\mathrm{A} / \mathrm{J}$, uma vez que essa linhagem já se mostrou permissiva à replicação de $C$. burnetii fase II para infecções em BMDMs. Verificamos que AMs de ambas as linhagens analisadas apresentaram-se igualmente suscetíveis à replicação de C. burnetii (Figura 6B), sugerindo que mecanismos genéticos presentes em BMDMs que estão envolvidos na resistência natural desse tipo celular à infecção por C. burnetii podem estar ausentes ou ser menos eficientes em AMs. Nesse contexto, AMs mostraram-se como um interessante modelo 
de macrófagos primários murinos altamente permissivos à replicação intracelular de $C$. burnetii fase II in vitro. Considerando a possível relevância desse modelo para estudos sobre as interações patógeno-hospedeiro durante as infecções com C. burnetii, decidimos caracterizar a replicação dessa bactéria em AMs. 


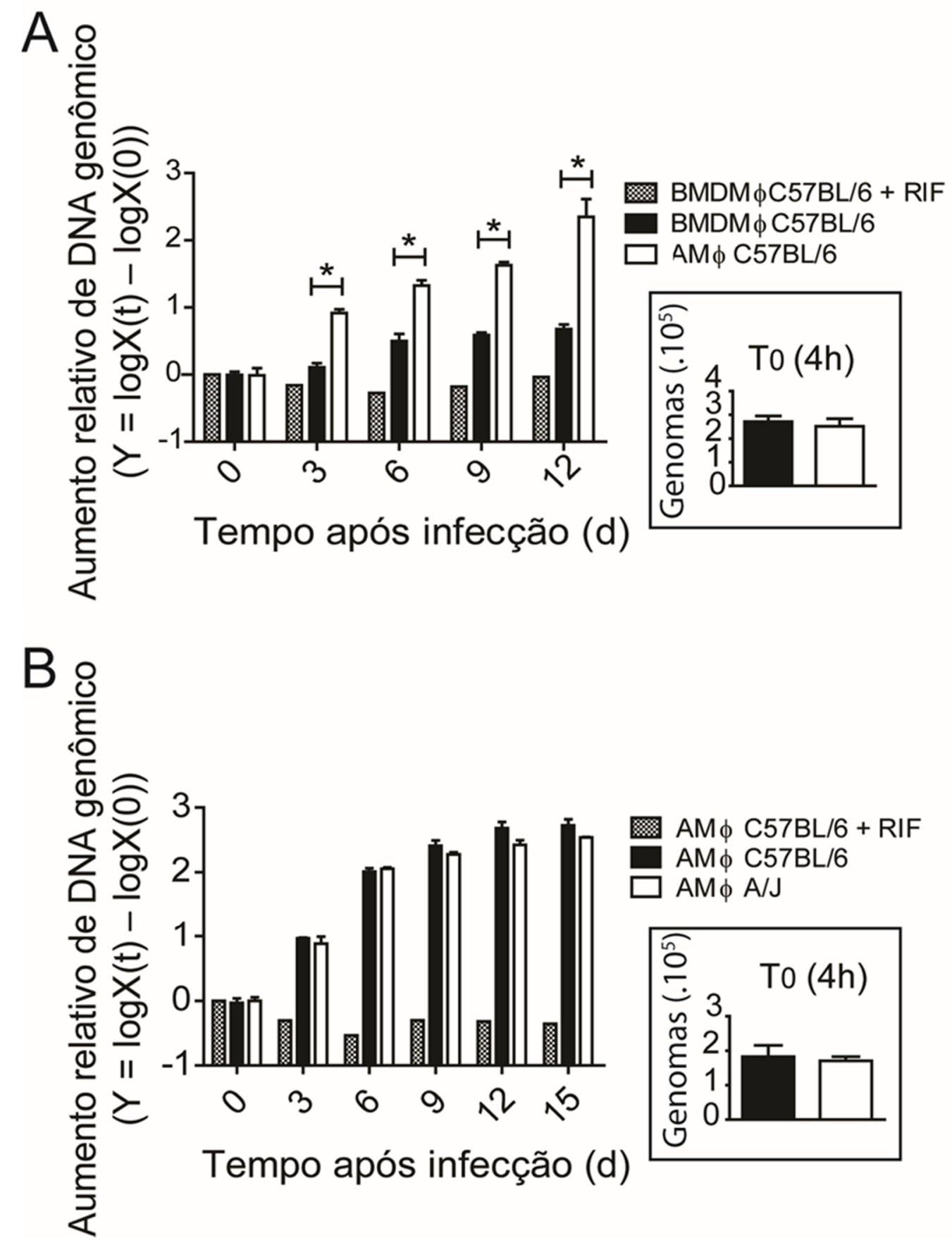

Figura 6 - Macrófagos alveolares murinos são permissivos à replicação de $\boldsymbol{C}$. burnetii fase II. BMDMs e AMs da linhagem C57BL/6 (A) e AMs das linhagens C57BL/6 e A/J (B) foram infectados com C. burnetii fase II com MOI 3. Após após 0 (4 horas após infecção), 3, 6, 9, 12 e 15 dias de infecção foi avaliada a multiplicação bacteriana por quantificação do DNA genômico por qPCR. O eixo y representa a diferença logarítmica na base 10 entre a quantificação genômica no tempo X e a quantificação no tempo $0(\log \mathrm{T}(\mathrm{X})-$ $\log \mathrm{T}(0)$ ). Células tratadas com o inibidor da tradução protéica bacteriana rifampicina (RIF) foram utilizadas como controle negativo da replicação bacteriana. Em destaque, os excertos mostram a quantidade de DNA genômico de $C$. burnetii 4 horas após a infecção. Barras de erro representam desvio padrão de triplicatas experimentais, e $\left(^{*}\right)$ indica $\mathrm{p}<0,05$; (two-way ANOVA). Os dados são representativos de três réplicas experimentais distintas. Adaptado de: FERNANDES et al (2016). 


\subsection{Macrófagos alveolares murinos suportam a replicação de grandes quantidades de bactéria intracelular nos vacúolos contendo $C$. burnetii fase II}

Como observado anteriormente, AMs murinos mostraram-se um modelo celular altamente permissivo à replicação de $C$. burnetii fase II in vitro, mesmo no fundo gênico geralmente restritivo de camundongos C57BL/6. Para caraterização da replicação da bactéria nesse modelo optamos por utilizar técnicas de microscopia como ferramenta de estudo, como já padronizado anteriormente (ZAMBONI; MORTARA; RABINOVITCH, 2001). AMs derivados de camundongos C57BL/6 foram infectados com C. burnetii fase II em um MOI 3 por quatro horas, três dias e seis dias, fixadas e a quantidade de bactéria intracelular foi avaliada por meio de microscopia de fluorescência multifóton. Para isso, as células foram marcadas com anticorpo primário anti-C. burnetii e anticorpo primário anti-LAMP-1, a fim de acompanhar o aumento da quantidade de bactéria nas células e visualizar se as mesmas estariam replicando dentro dos vacúolos parasitóforos característicos, os quais se tornam decorados com esse marcador lisossomal (GHIGO et al., 2009). Observamos que ao longo dos primeiros seis dias de infecção ocorre um aumento na quantidade de C. burnetii, visualizado pelo aumento da marcação em vermelho dentro dos AMs, sugerindo que a bactéria está replicando nessas células. Em adição, uma associação com a marcação de LAMP-1, em verde, sugere que essa replicação está de fato ocorrendo dentro dos típicos vacúolos contendo C. burnetii (Figura 7A).

Apesar do aumento na quantidade de C. burnetii dentro dos AMs e a associação com LAMP-1 ter sido constatada, os processos envolvidos na preparação das amostras e marcação com anticorpos dos alvos de interesse para visualização em microscópio de fluorescência levaram à perda daquelas células que apresentam grandes e espaçosos vacúolos parasitóforos, já que essas células facilmente se soltam do fundo das lamínulas e são perdidas durante os processos de lavagem. Dessa forma, visando analisar a presença dos grandes vacúolos típicos que são desenvolvidos durante a infecção com C. burnetii em AMs, optamos por utilizar na infecção uma cepa de C. burnetii fase II expressando mCherry (BEARE et al., 2011). A análise dos AMs por microscopia de fluorescência multifóton mostrou novamente um aumento significativo na quantidade de bactéria ao longo do curso de 12 dias de infecção, representada pelo aumento da intensidade da marcação em vermelho proveniente das $C$. burnetii expressando mCherry (Figura 7B). Após seis dias de infecção já era possível observar que várias células continham grande quantidade de bactéria em vacúolos espaçosos, com essas bactérias tomando completamente o espaço celular após nove dias de infecção, 
como ilustrado com a sobreposição das imagens de fluorescência e contraste diferencial de interferência (Figura 7C).

Além da microscopia de fluorescência, utilizamos a microscopia eletrônica de transmissão para caracterizar a replicação intracelular de C. bunetii fase II nos AMs (Figura 8). Novamente, AMs derivados de camundongos C57BL/6 foram infectados com C. burnetii fase II in vitro utilizando MOI 3, com as amostras sendo fixadas e preparadas para microscopia eletrônica de transmissão após três e seis dias, como descrito previamente por Zamboni e colaboradores (2002). Três dias após a infecção, as células mostravam grandes vacúolos espaçosos contendo em seu interior várias variantes celulares grandes de C. burnetii (Figura 8A). Após seis dias de infecção foi possível observar um aumento considerável na quantidade de bactérias dentro dos vacúolos (Figura 8B), demonstrando novamente que AMs são permissivos à replicação de $C$. burnetii fase II in vitro e podem ser utilizados como um modelo relevante de macrófagos primários para estudar infecções com essa bactéria. 


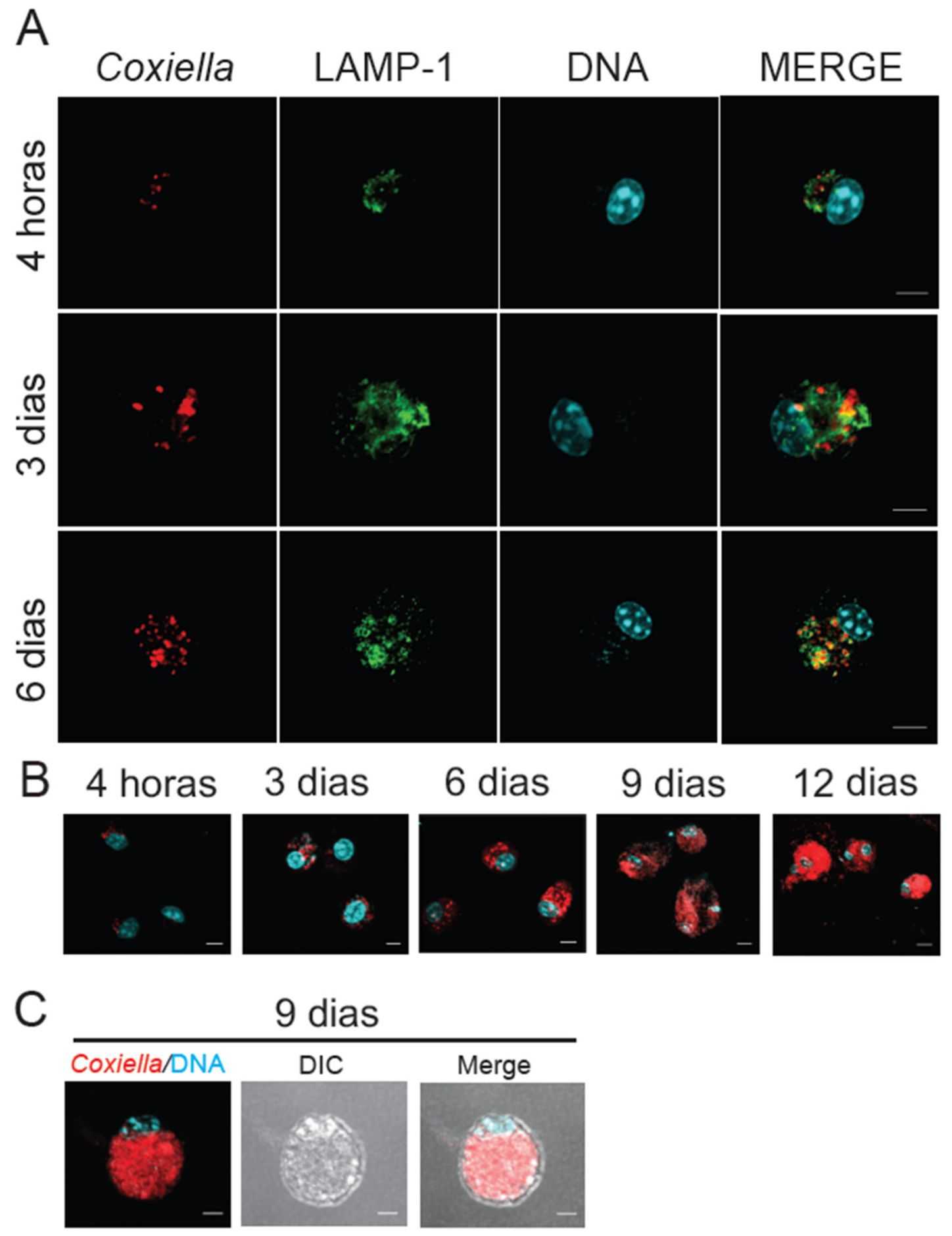

Figura 7 - Localização intracelular de $C$. burnetii fase II em macrófagos alveolares murinos visualizada por microscopia confocal de fluorescência. AMs de camundongos C57BL/6 foram infectados com C. burnetii fase II selvagem (MOI 3) por 4 horas, 3 e 6 dias (A) ou infectadas com C. burnetii fase II expressando $m$ Cherry (MOI 3) por 4 horas, 3, 6, 9 e 12 dias (B). Após os tempos indicados, as células foram fixadas, processadas e então examinadas utilizando microscopia de fluorescência multifóton. (C) AMs infectados por 9 dias com $C$. burnetii expressando mCherry. As imagens foram adquiridas por microscopia de multifóton utilizando objetiva de óleo de imersão de aumento de 63X e analisadas utilizando o software ImageJ . DIC, do inglês Differential Interference Contrast. Verde, proteína lisossomal associada à membrana LAMP-1; vermelho, C. burnetii, ciano, DNA corado com DAPI. Barras de escala, $5 \mu \mathrm{m}$. Adaptado de: FERNANDES et al (2016). 

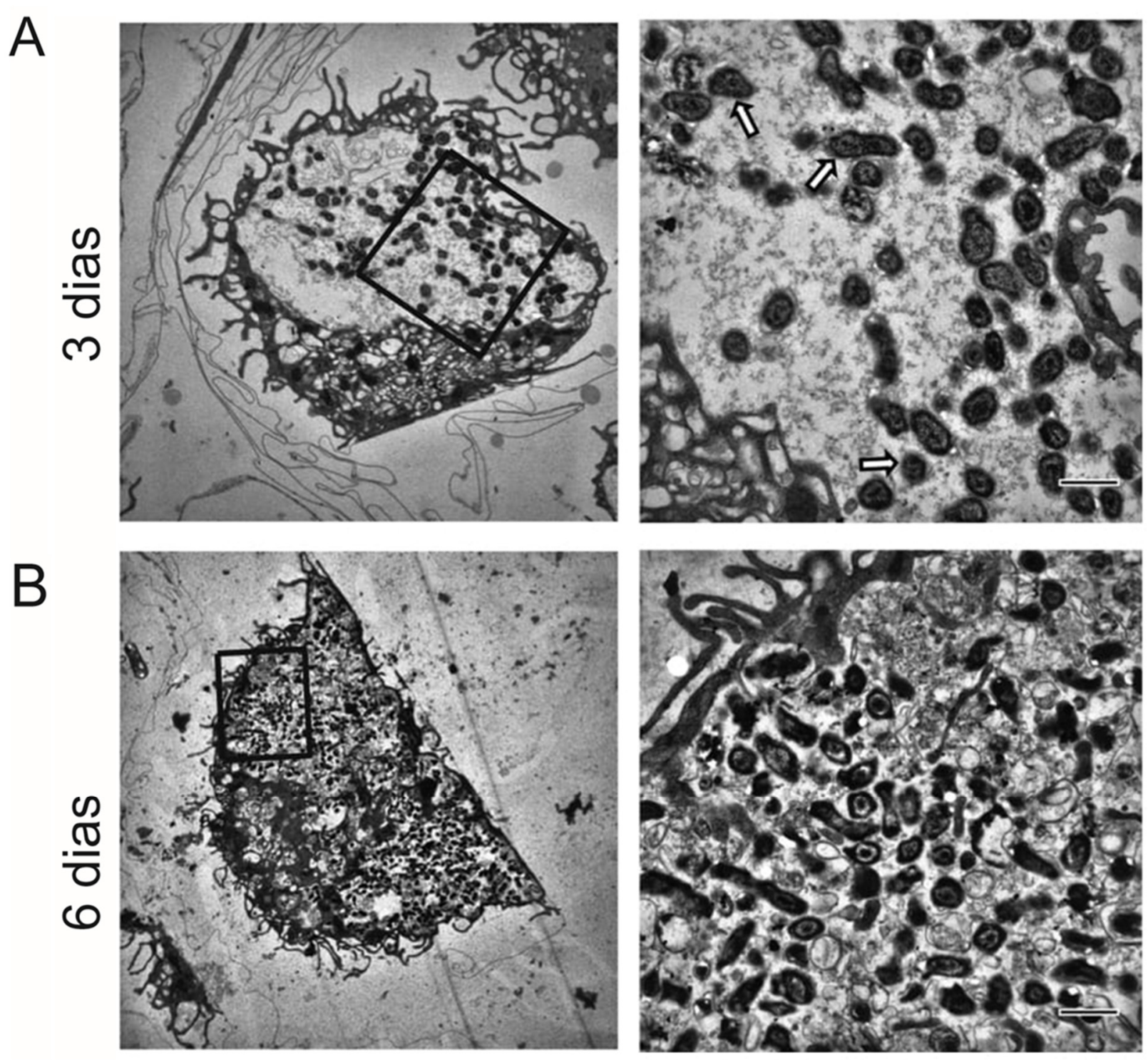

Figura 8 - Localização intracelular de $\boldsymbol{C}$. burnetii fase II em macrófagos alveolares murinos visualizada por microscopia eletrônica de transmissão. AMs derivados de camundongos C57BL/6 foram infectados com C. burnetii fase II (MOI 3), fixados e processados para microscopia eletrônica de transmissão. Células foram fixadas após 3 (A) e 6 dias (B) de infecção. Os painéis da direita são imagens aumentadas das regiões destacadas nos painéis à esquerda. Setas, formas variantes celulares grandes de C. burnetii. Barras de escala, $1 \mu \mathrm{m}$. Adaptado de: FERNANDES et al (2016). 


\subsection{Macrófagos alveolares murinos mostram uma polarização mais pronunciada em células do tipo M2 do que macrófagos murinos derivados de medula óssea}

Após demonstrar por técnicas de microscopia que AMs murinos são de fato permissivos à replicação de C. burnetii fase II in vitro, nosso próximo objetivo foi buscar entender quais os mecanismos por trás da grande suscetibilidade apresentada por esse modelo. Sabe-se que a replicação e patogênese de C. burnetii estão relacionadas com o padrão de polarização induzido em macrófagos e monócitos, sendo que de forma geral a indução de um padrão M1 resulta em maior atividade pró-inflamatória, com desenvolvimento de funções microbicidas que levam à eliminação do patógeno, enquanto que a indução de um padrão M2 reflete em ações com um perfil mais anti-inflamatório, permitindo assim a replicação do patógeno (MURRAY et al., 2017; SHAPOURI-MOGHADDAM et al., 2018). Em 2008, Benoit e colaboradores demonstraram que a infecção de macrófagos derivados de monócitos humanos por C. burnetii resultava na indução de um programa atípico de polarização em um estado M2, levando à persistência da bactéria nas células (BENOIT et al., 2008). Esse estado de polarização atípico era acompanhado pelo aumento na expressão de genes relacionados com o padrão M2, como Arginase-1, IL-10, TGF- $\beta$ e receptores de manose, e pela diminuição na expressão de genes considerados marcadores clássicos do padrão M1, como TLR2 e TNF. Dessa forma, resolvemos investigar qual padrão de polarização estaria sendo induzido no modelo de AMs murinos.

Visando determinar o padrão de polarização apresentado por AMs murinos, avaliamos inicialmente a expressão de genes considerados como marcadores dos padrões M1 e M2 em AMs e comparamos com a expressão em BMDMs murinos, por meio de RT-PCR (do inglês, Reverse $\underline{\text { Transcription-PCR}})$. Para isso, mRNA de culturas de $10^{6}$ AMs e BMDMs de camundongos C57BL/6, infectados ou não por 12 horas com C. burnetii fase II (MOI 3), foram extraídos, purificados e quantificados. Após a realização de reações de termociclagem e leitura em um sistema de PCR em tempo real, a expressão dos genes de interesse foi calculada utilizando os valores do ciclo médio do limite (CT) para cada amostra, os quais foram normalizados com relação aos valores de CT dos genes housekeeping. Os genes Nos2, Tnfa, Ifng e Tlr2 foram selecionados como marcadores representantes do padrão de polarização M1, enquanto que os genes Arginase1, Fizzl e Yml foram selecionados como marcadores representantes do padrão de polarização M2. Para as análises em questão e normalização dos cálculos de CT, o gene Gapdh foi selecionado como representante do gene housekeeping 
Analisando inicialmente a expressão gênica em AMs e BMDMs murinos não infectados, observamos que AMs apresentam uma expressão consideravelmente reduzida de Nos2, Tnfa, Ifng e Tlr2, genes associados a um fenótipo de polarização padrão M1. Em contrapartida, a expressão dos genes Arginasel, Fizzl e Yml, genes associados com um fenótipo de polarização padrão M2, mostraram-se aumentadas. Comparativamente, BMDMs murinos não infectados apresentaram um perfil inverso ao observado em AMs, com expressão aumentada dos genes associados ao padrão M1 e expressão reduzida de Arginase1 e Ym1 (Figura 9). Após a infecção com C. burnetii fase II por 12 horas, novamente AMs mostraram uma polarização padrão M2 pronunciada quando comparada com aquela apresentada por BMDMs. Essa forte polarização em um perfil M2 por AMs infectados foi representada pelo aumento na expressão de Il4, Arginase1, Fizzl e Ym1 e redução na expressão de Nos2, Tnfa, Ifng e Tlr2 em comparação com a expressão desses mesmos genes em BMDMs infectados (Figura 9). Conjuntamente, esses dados são consistentes com o perfil altamente suscetível dos AMs murinos observado frente à infecção in vitro por C. burnetii fase II, uma vez que essas células polarizariam para um padrão M2 mais tolerogênico.

Em concordância com os resultados obtidos, sabe-se que macrófagos com perfil de polarização M1 desencadeiam a produção de TNF- $\alpha$, uma citocina pró-inflamatória já descrita como sendo importante para restrição da replicação de C. burnetii em macrófagos (BRADLEY et al., 2016). A restrição ao crescimento bacteriano observada em BMDMs murinos da linhagem C57BL/6 pode estar em parte relacionada justamente com essa polarização em um perfil mais M1, como observado pelo aumento na expressão do gene Tnf $\alpha$ após a infecção por C. burnetii, o que não ocorreria para AMs. Para continuar testando a hipótese de que a grande permissividade de AMs murinos à replicação de C. burnetii fase II seria decorrente de um estado de polarização padrão M2 nessas células, decidimos avaliar a expressão de alguns marcadores de superfície conhecidos classicamente relacionados com macrófagos polarizados nesse padrão, sendo eles o receptor de manose (CD206) e dectina-1 (CLEC7A) (MARTINEZ et al., 2006). Para isso, foram realizados experimentos de FACS (do inglês, Fluorescence-Activated Cell Sorting) em suspensões únicas de AMs e BMDMs não infectados ou infectados com C. burnetii fase II (MOI 3) por 48 horas, inicialmente marcadas com corantes do kit de viabilidade celular LIVE/DEAD fixable blue dead cell stain kit para exclusão das células mortas na análise. Aquelas que se mostraram viáveis foram posteriormente coradas com anticorpos conjugados a fluorocromos contra os marcadores de superfície Cd11b, F4/80, CD206, CD86 e dectina-1/CLEC7A, lavadas e então adquiridas em 
citômetro de fluxo. Para cada amostra, pelo menos 100.000 eventos foram coletados. Os dados foram em seguida analisados com o programa FlowJo (TreeStar).

Para as análises de fenotipagem dos marcadores de superfície citados anteriormente, foram consideradas apenas as células vivas, duplo-positivas para Cd11b e F4/80 (Figuras 10A e 10B). Mesmo sem o estímulo infeccioso, AMs murinos mostraram expressão aumentada do receptor de manose (CD206) e dectina-1 (CLEC7A), moléculas associadas com o padrão de polarização M2, em comparação com a expressão dessas mesmas moléculas em BMDMs murinos (Figura 10C). Após a infecção com C. burnetii fase II, o mesmo cenário foi observado com relação ao padrão de expressão das moléculas associadas ao perfil de polarização M2 em AMs e BMDMs (Figura 10D). Adicionalmente, avaliamos os níveis de expressão da molécula co-estimulatória CD86, os quais se apresentaram semelhantes em AMs e BMDMs, infectados ou não (Figuras 10C e 10D, respectivamente). Coletivamente, esses dados são consistentes com a hipótese de que AMs apresentam maior suscetibilidade devido ao seu estado de polarização em um padrão M2, característica essa que já foi anteriormente relacionada com permissividade à replicação de C. burnetii (BENOIT; DESNUES; MEGE, 2008). 


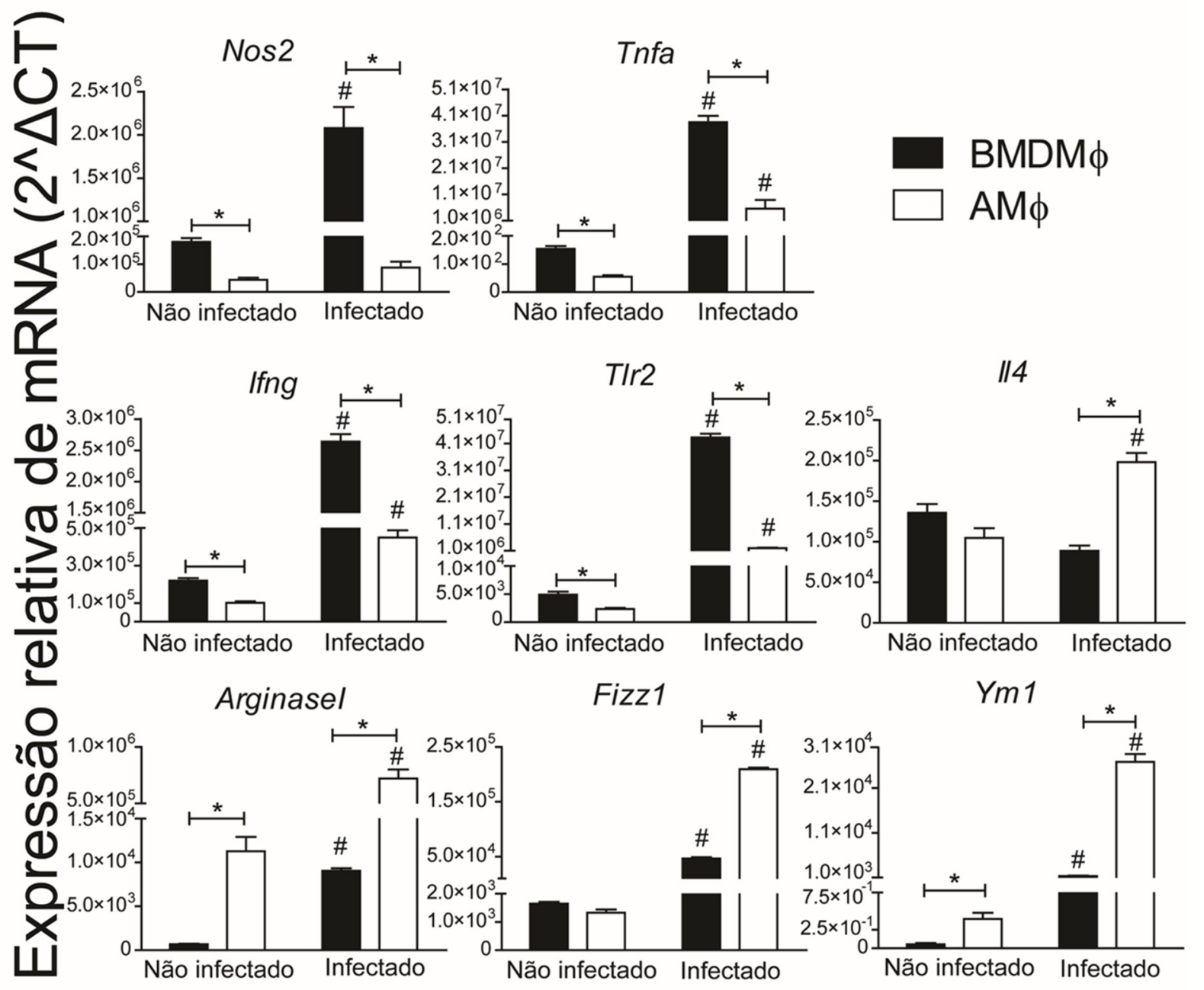

Figura 9 - Macrófagos alveolares murinos exibem níveis mais elevados de expressão de genes relacionados com o padrão de polarização M2. BMDMs e AMs derivados de camundongos C57BL/6 foram ou não infectados com $C$. burnetii fase II (MOI 3) por 12 horas. O RNA total das células foi extraído, e a reação de PCR de transcrição reversa (RT-PCR) foi realizada para detecção dos genes Nos2, Tnf $\alpha$, Ifn $\gamma$, Tlr2, Il4, Arginase1, Fizzl e Ym1, genes considerados marcadores dos padrões de polarização M1 e M2. Os dados mostrados representam a média \pm o desvio padrão de um experimento representativo de dois realizados. ${ }^{*}, P<0.05$ comparando BMDMs e AMs; \#, $P<0.05$ comparando células infectadas com células não infectadas do respectivo grupo (two-way ANOVA). Adaptado de: FERNANDES et al (2016). 
A

Estratégia de seleção para BMDM $\phi$

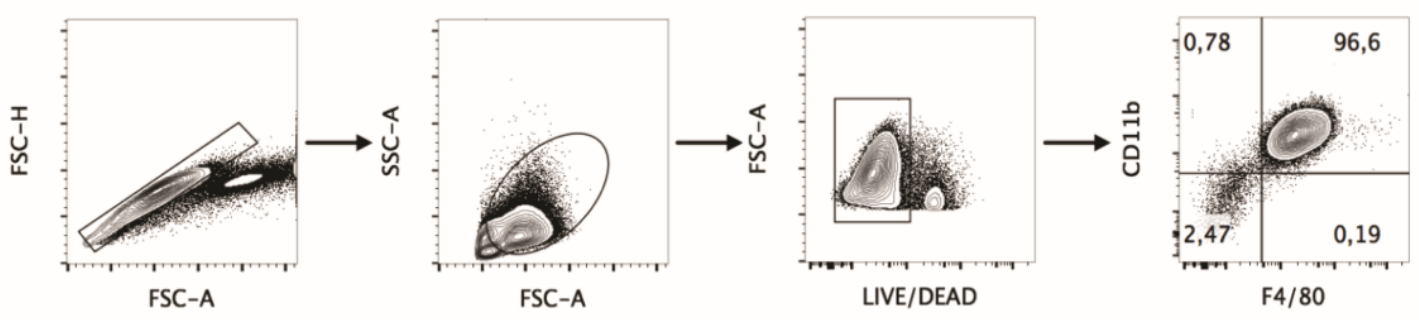

B Estratégia de seleção para AM $\phi$

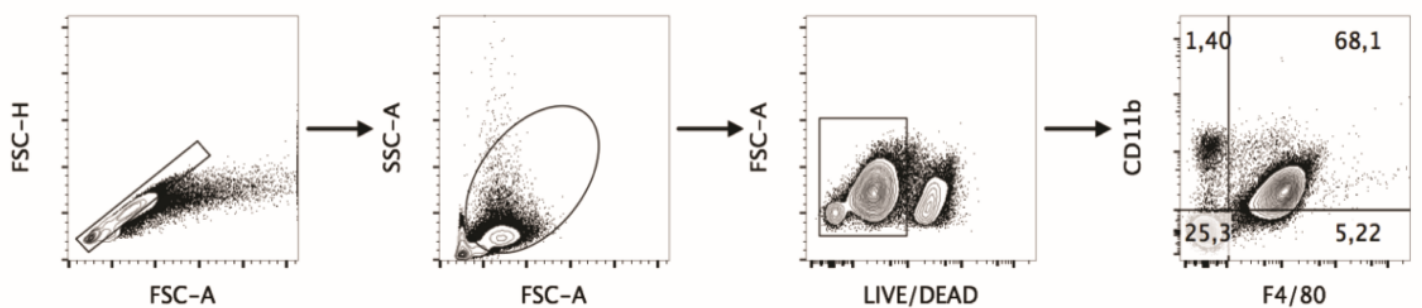

C
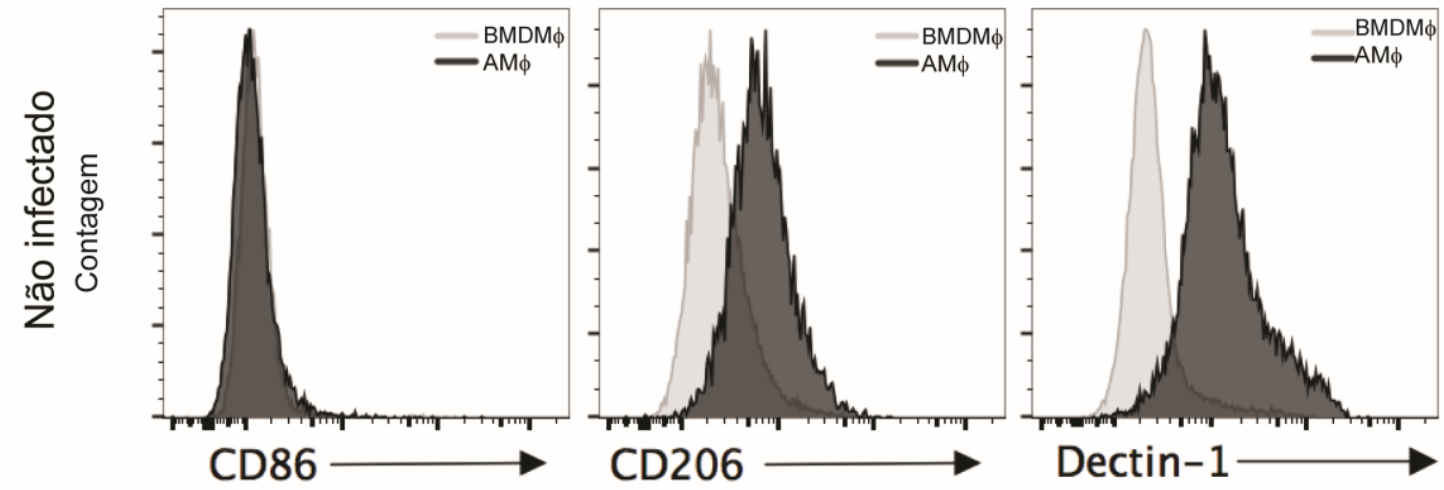

D
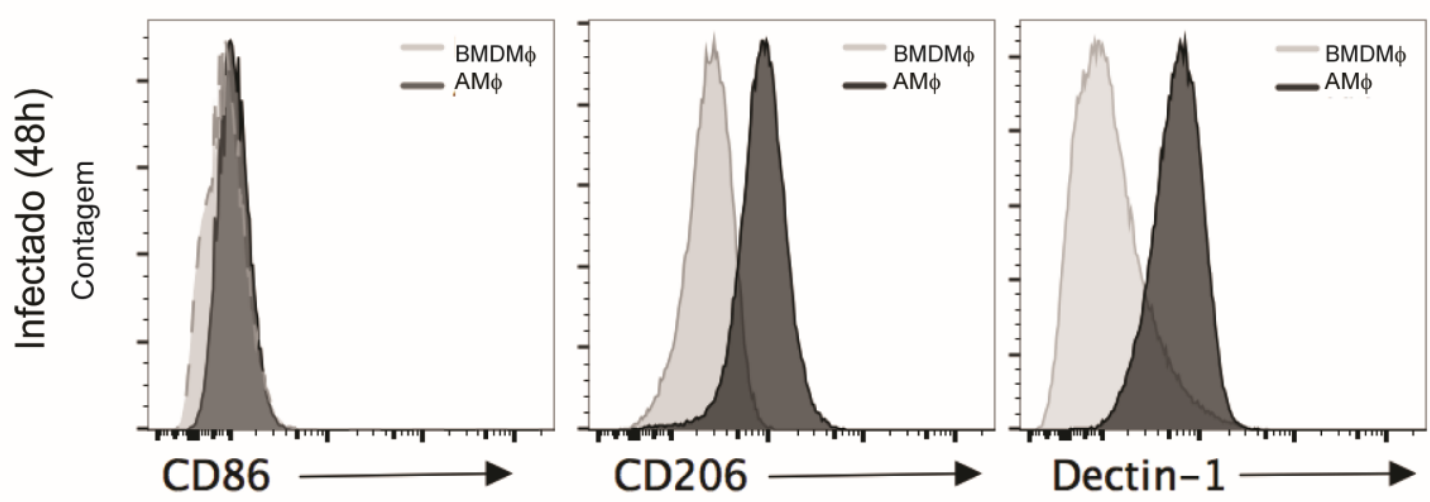

Figura 10 - Macrófagos alveolares murinos exibem um fenótipo de polarização M2. Estratégia de gates utilizada e frequência de BMDMs (A) e AMs (B) murinos derivados de camundongos C57BL/6 não infectados.

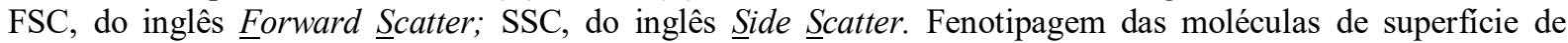
BMDMs e AMs murinos não infectados (C) ou infectados por 48 horas (D) com C. burnetii fase II para a molécula co-estimulatória CD86 e para os marcadores do padrão de polarização M2 CD206 (receptor de manose) e dectina-1, conforme analisado por citometria de fluxo. Foram selecionadas células vivas $\mathrm{Cd}_{11} \mathrm{~b}^{+}$ F4/80 ${ }^{+}$. Adaptado de: FERNANDES et al (2016). 


\subsection{Macrófagos alveolares murinos deficientes em NOS2 e IFN $\gamma$ são mais suscetíveis à replicação de $C$. burnetii fase II, enquanto células deficientes em interleucina-4 (IL-4) são mais restritivas à replicação da bactéria}

Demonstramos anteriormente, por meio de técnicas de microscopia e quantificação de DNA genômico por qPCR, que AMs murinos são altamente suscetíveis à replicação de $C$. burnetii fase II in vitro. Determinamos, ainda, que essa permissividade aumentada ocorre devido ao fato de que essas células apresentam uma polarização padrão M2. Em conjunto, esses achados apontam para AMs como sendo um modelo relevante para estudos envolvendo as interações patógeno-hospedeiro em macrófagos primários frente as infecções in vitro com C. burnetii fase II. Sendo assim, buscamos validar esse modelo de estudo proposto.

Sabe-se que apesar da bactéria apresentar grande capacidade de evadir e subverter a resposta imune do hospedeiro, respostas efetivas ainda ocorrem. Um dos mecanismos importantes envolvidos na restrição do crescimento de C. burnetii se dá pela ação de espécies reativas de nitrogênio, com o óxido nítrico (NO) desempenhando um papel fundamental (YOSHIIE et al., 1999; HOWE et al., 2002; ZAMBONI; RABINOVITCH, 2003; BRENNAN et al., 2004; ZAMBONI; RABINOVITCH, 2004). Dessa forma, para fortalecer nossa proposta da relevância da utilização de AMs murinos como modelo de estudo das interações de $C$. burneti com macrófagos murinos primários, nosso próximo passo foi avaliar a replicação da bactéria em AMs murinos deficientes para NOS2 (do inglês, Nitric Oxide

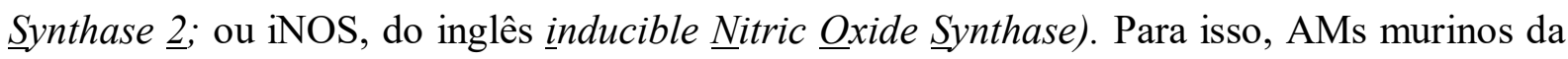
linhagem C57BL/6, selvagens (WT) ou deficientes para NOS2 $\left(\mathrm{Nos}^{-/-}\right)$, foram obtidos e infectados (MOI 3) com C. burnetii fase II in vitro por 12 dias, com as amostras sendo lisadas e coletadas em intervalos de três dias. Novamente um grupo contendo rifampicina foi utilizado como controle experimental interno. Após purificação das amostras e quantificação por qPCR, assim como esperado e em conformidade com o que já estava descrito na literatura, AMs de camundongos $N_{o s} 2^{-/}$se mostraram mais permissivos à replicação de $C$. burnetii fase II do que AMs de camundongos WT (Figura 11A), reforçando a importância de NO para o controle da replicação por essa bactéria.

Em seguida, avaliamos também a replicação bacteriana em AMs derivados de camundongos deficientes para IFN- $\gamma\left(\right.$ Ifng $\left.^{-/}\right)$, visto que essa molécula é essencial para produção de $\mathrm{NO}$ e, assim como NO, desempenha um papel microbicida fundamental nas infecções por C. burnetii (TURCO; THOMPSON; WINKLER, 1984; DELLACASAGRANDE et al., 1999; DINAKAR et al., 1999; GHIGO et al., 2002; AMARA; 
BECHAH; MEGE, 2012). Observamos que ao longo de 12 dias de infecção AMs derivados de camundongos Ifng $^{-/}$são significativamente mais permissivos à replicação de C. burnetii fase II do que AMs derivados de camundongos WT (Figura 11B). Coletivamente, esses resultados suportam o uso de AMs murinos como um modelo relevante para investigações envolvendo infecções com C. burnetii fase II em macrófagos primários de camundongos C57BL/6, a linhagem mais comumente utilizada para geração de camundongos transgênicos, uma ferramenta fundamental para estudos sobre interações patógeno-hospedeiro.

Posteriormente, para compreender melhor o efeito da polarização M2 de AMs murinos na alta suscetibilidade dessas células à infecção por $C$. burnetii fase II, infectamos AMs derivados de camundongos selvagens ou deficientes para IL-4 (Il/ $\left.4^{-/}\right)$e avaliamos a replicação bacteriana. Cabe ressaltar que IL-4 é um dos principais estímulos clássicos para indução da polarização no padrão M2, juntamente com IL-13, com ambos ativando STAT6 via receptor IL-4R $\alpha$ (MANTOVANI et al., 2013; MURRAY, 2017; SHAPOURI-MOGHADDAM 2018). Vimos que na ausência de IL-4 os AMs tornam-se mais restritivos à replicação de C. burnetii (Figura 11C), o que pode ser explicado pelo fato de que sem IL-4 há um prejuízo na polarização dessas células para um padrão M2, mais suscetível ao crescimento bacteriano, corroborando os resultados obtidos até então. Importante reforçar que a ausência de NOS2, IFN- $\gamma$ e IL-4 não interferiram na internalização da bactéria pelos AMs, como pode ser observado na quantificação do DNA genômico de C. burnetii após quatro horas de infecção (Figuras 11A-C, excertos em destaque). Em conjunto, esses dados suportam a hipótese de que a polarização em um padrão M1 ou M2 está por trás da suscetibilidade aumentada de AMs murinos à infecção por C. burnetii fase II em comparação com BMDMs. Além disso, é preciso destacar que, independentemente dos mecanismos que possam estar associados à resistência apresentada pelos BMDMs, ainda assim esses dados suportam o uso de AMs murinos como um importante e relevante modelo celular para análises da replicação de $C$. burnetii em macrófagos primários. 

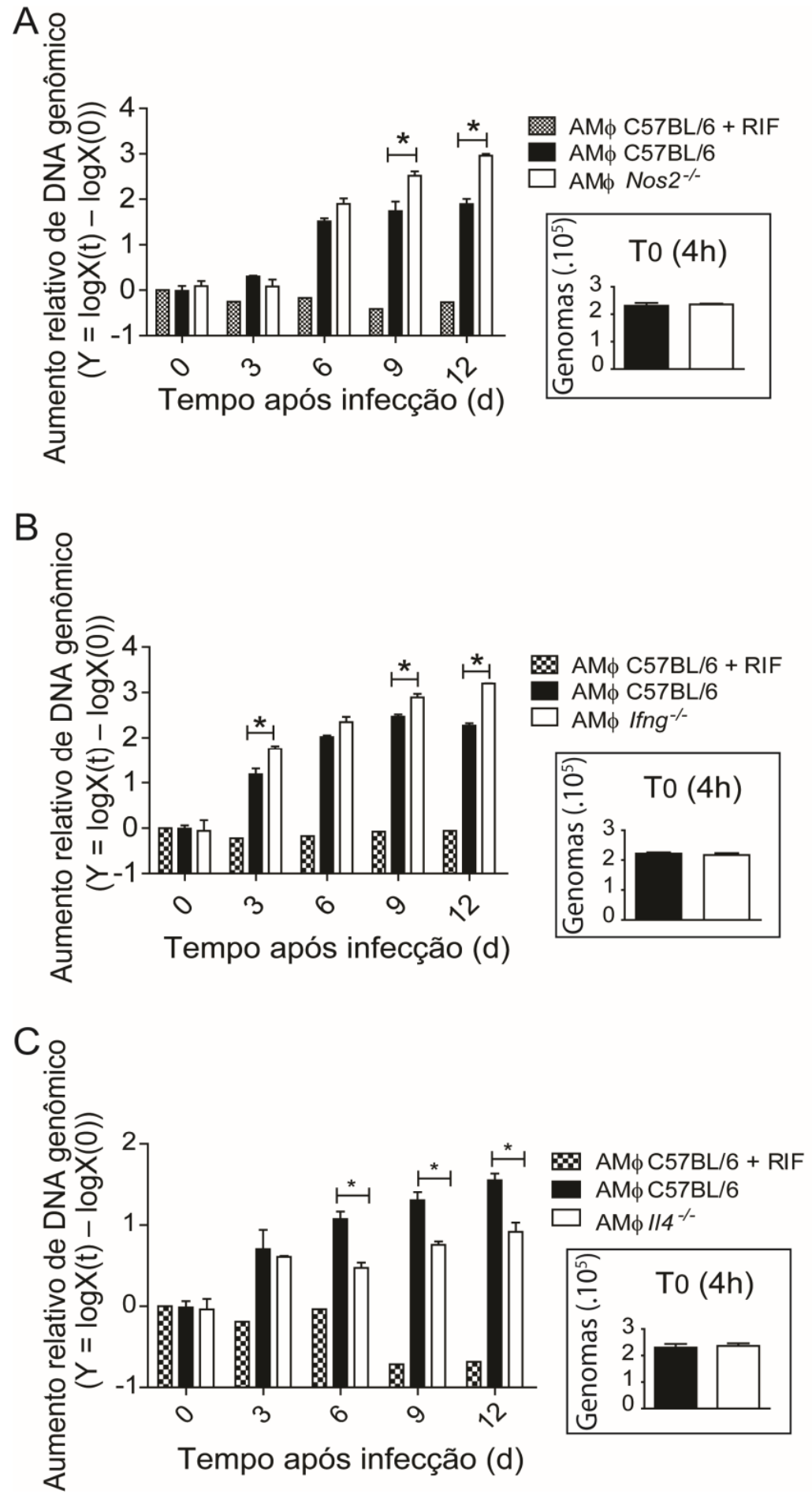

Figura 11 - Macrófagos alveolares murinos possibilitam a utilização de macrófagos deficientes no fundo gênico C57BL/6 para avaliação da resposta imune inata contra $\boldsymbol{C}$. burnetii fase II. AMs primários derivados de camundongos C57BL/6 WT e $\mathrm{Nos}^{2 /-}$ (A), Ifng ${ }^{-/}$(B) e $\mathrm{Il}_{-1 /}^{-/}$(C) foram infectados com C. burnetii fase II (MOI 3) e a multiplicação bacteriana foi avaliada por quantificação do DNA genômico por qPCR após 0 (4 horas após infecção), 3, 6,9 e 12 dias de infecção. O eixo y representa a diferença logarítmica na base 10 entre a quantificação genômica no tempo X e a quantificação no tempo $0(\log \mathrm{T}(\mathrm{X})-\log \mathrm{T}(0))$. Células tratadas com o inibidor da tradução protéica bacteriana rifampicina (RIF) foram utilizadas como controle negativo da replicação bacteriana. Em destaque, os excertos mostram a quantidade de DNA genômico de C. burnetii 4 horas após a infecção. Barras de erro representam desvio padrão de triplicatas experimentais, e $(*)$ indica $p<0,05$; (two-way ANOVA). Os dados são representativos de três réplicas experimentais distintas. Adaptado de: FERNANDES et al (2016). 


\subsection{A permissividade dos macrófagos alveolares murinos à infecção por $C$. burnetii fase II é comparável a aquelas de linhagens celulares imortalizadas altamente suscetíveis}

Conforme demonstramos anteriormente, nossos resultados mostraram que AMs murinos são permissivos à replicação de C. burnetii fase II in vitro. Por fim, para ressaltar a relevância e aplicabilidade desse modelo murino primário de infecção para estudos com $C$. burnetii, optamos por comparar a multiplicação dessa bactéria em AMs derivados de camundongos C57BL/6 com linhagens celulares imortalizadas altamente suscetíveis. Utilizamos células Vero, uma linhagem celular derivada de rins de macaco verde, e células THP-1, uma linhagem celular monocítica humana. Para esses experimentos as células Vero foram previamente irradiadas, a fim de garantir que apenas mais um ciclo de replicação ocorreria após o plaqueamento das mesmas. Desta forma, a quantidade de bactéria não seria diluída pela replicação das células. As células THP-1 foram previamente diferenciadas durante a noite em células do tipo macrófago por meio da adição de $200 \mathrm{nM}$ de forbol 12 miristato 13-acetato (PMA) na cultura, como descrito anteriormente (VOTH; HOWE; HEINZEN, 2007). Os AMs derivados de camundongos C57BL/6 foram obtidos e plaqueados como já descrito anteriormente. No dia seguinte, todas as células tiveram os meios de cultura trocados por meio fresco antes da infecção com C. burnetii fase II (MOI 3).

Tanto células Vero quanto células THP-1 já foram descritas como sendo altamente permissivas à replicação de C. burnetii (ZAMBONI; MORTARA; RABINOVITCH, 2001; GHIGO et al., 2002; HOWE et al., 2010), o que foi também observado por nós ao longo de 12 dias de infecção. Após seis dias de infecção com C. burnetii fase II em um MOI 3, AMs murinos se mostraram tão suscetíveis quanto as células Vero e as células THP-1 (Figura 12). Já nos tempos mais tardios da infecção, a replicação bacteriana observada em células Vero e células THP-1 foi mais robusta do que a apresentada por AMs murinos. Apesar disso, a taxa comparável de replicação de C. burnetii fase II durante os primeiros seis dias de infecção reforçam a demonstração de que AMs murinos são, de fato, altamente permissivos à replicação dessa bactéria e podem ser usados como um modelo celular primário do hospedeiro altamente relevante para investigações acerca da interação de macrófagos com C. burnetii fase II em cultura. 


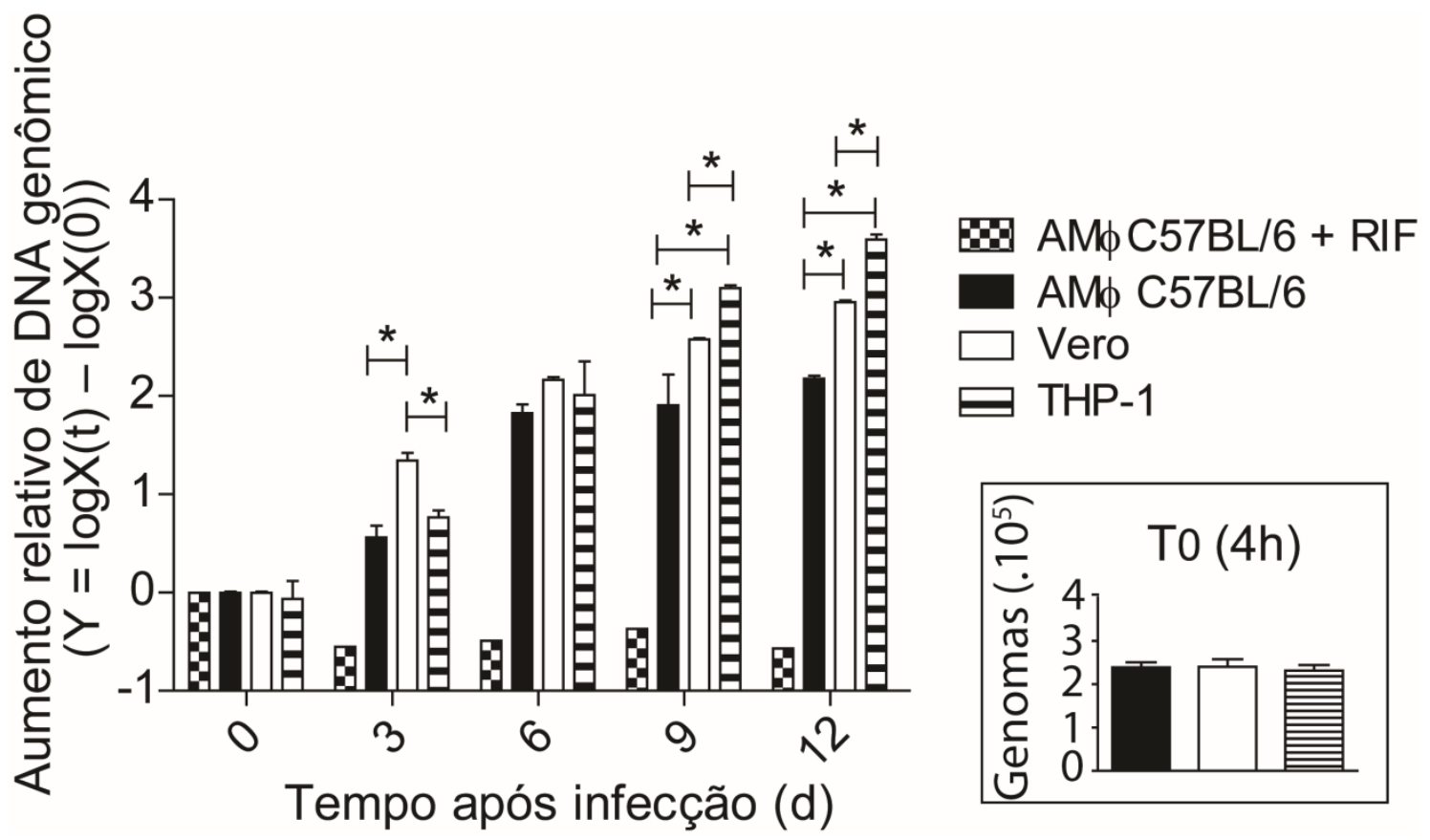

Figura 12 - Macrófagos alveolares murinos são permissivos à replicação de $\boldsymbol{C}$. burnetii fase II in vitro de forma semelhante às células Vero e células THP-1. AMs derivados de camundongos C57BL/6, células Vero irradiadas e células THP-1 (previamente diferenciadas overnight com 200nM de PMA) foram infectadas com $C$. burnetii fase II (MOI 3) e a multiplicação bacteriana foi avaliada por quantificação do DNA genômico por qPCR após 0 (4 horas após infecção), 3, 6, 9 e 12 dias de infecção. O eixo y representa a diferença logarítmica na base 10 entre a quantificação genômica no tempo $\mathrm{X}$ e a quantificação no tempo $0(\log \mathrm{T}(\mathrm{X})-\log \mathrm{T}(0))$. Células tratadas com o inibidor da tradução protéica bacteriana rifampicina (RIF) foram utilizadas como controle negativo da replicação bacteriana. Em destaque, os excertos mostram a quantidade de DNA genômico de $C$. burnetii 4 horas após a infecção. Barras de erro representam desvio padrão de triplicatas experimentais, e (*) indica $\mathrm{p}<0,05$; (two-way ANOVA). Os dados são representativos de três réplicas experimentais distintas. Adaptado de: FERNANDES et al (2016). 


\section{DISCUSSÃO}

Apesar do grande interesse biomédico de C. burnetii e do fato de que essa bactéria é extremamente virulenta e altamente adaptada à evasão da resposta imune, os mecanismos pelos quais os macrófagos e monócitos, células-alvo da infecção, reconhecem C. burnetii, bem como as interações patógeno-hospedeiro que acontecem durante a infecção, ainda precisam ser melhor compreendidos (AMARA; BECHAH; MEGE, 2012). O aprimoramento das técnicas de cultivo axênico da bactéria abriu caminho para manipulação genética mais eficiente de C. burnetii, possibilitando a geração de um número cada vez maior de bactérias mutantes (OMSLAND et al., 2009; OMSLAND et al., 2011). Como consequência, novos efetores bacterianos e suas funções têm sido descobertos, ajudando a compreender de que forma C. burnetii interage com seus hospedeiros (CUNHA et al., 2015; QIU; LUO, 2017; WALLQVIST et al., 2017; CRABILL et al., 2018; WEBER; FARIS, 2018). Entretanto, o entendimento das relações patógeno-hospedeiro não depende apenas do desevolvimento de técnicas de manipulação do patógeno. É fundamental, também, determinar modelos de estudo apropriados. Nesse contexto, a falta de um modelo relevante de célula primária, principalmente um que permita a utilização dos diversos camundongos geneticamente modificados disponíveis no fundo gênico restritivo C57BL/6, é um problema fundamental que precisa ser endereçado. Isso nos levou, nesse trabalho, a buscar qual seria o modelo adequado de célula primária que pudesse ser utilizado nos estudos com C. burnetii fase II.

Já foi descrito na literatura que alguns hospedeiros conseguem restringir o crescimento de C. burnetii, com camundongos da linhagem C57BL/6 sendo resistentes à infecção, enquanto que camundongos das linhagens BALB/c e A/J são suscetíveis (ZAMBONI, 2004; ZAMBONI; RABINOVITCH, 2004). Os mecanismos existentes por trás dessa diferença de suscetibilidade entre as linhagens não são conhecidos, mas uma hipótese possível é que sejam decorrentes de características inerentes ao próprio fundo gênico dos camundongos. Há, ainda, diferenças de suscetibilidade dependendo do tipo celular analisado, com macrófagos peritoneais primários e macrófagos derivados de medula óssea apresentando-se mais intrinsicamente restritivos à bactéria, assim como monócitos, os quais apresentam um perfil de polarização do tipo M1 e são mais restritivos à replicação de C. burnetii (ZAMBONI et al., 2002; ZAMBONI; RABINOVITCH, 2003; BENOIT et al., 2008; CAPO; MEGE, 2012; ELDIN, 2017). Nesse caso, é possível que a diferença de suscetibilidade entre os tipos celulares seja reflexo de origens embrionárias distintas, ou mesmo de um microambiente tecidual diferente a qual cada célula é exposta. 
A escolha de macrófagos como modelo celular para os estudos da interação patógenohospedeiro nas infecções com C. burnetii levou em consideração o fato de que essa é uma das principais células-alvo na infecção pela bactéria, além de considerar a plasticidade e relevância dos macrófagos na participação de diferentes funções nos organismos, tais como desenvolvimento e homeostase de tecidos, reparação tecidual, fagocitose de patógenos, produção de citocinas e outros aspectos da resposta imune (MANTOVANI et al., 2002; MANTOVANI et al., 2004; AMARA; BECHAH; MEGE, 2012 WYNN; CHAWLA; POLLARD, 2013). Para estudos com infecções por C. burnetii, macrófagos peritoneais murinos e macrófagos murinos derivados de medula óssea (BMDMs) são muito utilizados (ZAMBONI et al., 2002; ZAMBONI; RABINOVITCH, 2003; ZAMBONI, 2004; ZAMBONI; RABINOVITCH, 2004), com os últimos sendo de particular relevância visto que é possível congelar os BMDMs por longos períodos de tempo e ainda assim manter sua capacidade de diferenciação e funções de forma comparável a BMDMs frescos (MARIM et al., 2010). Além deles, os macrófagos alveolares compreendem outro modelo importante de estudo, uma vez que a infecção por C. burnetii se dá via aerossol. Dados da literatura mostram a utilização de macrófagos alveolares isolados de tecidos post-mortem de seres humanos, macrófagos alveolares derivados de macacos e macrófagos alveolares murinos para avaliação das interações patógeno-hospedeiro envolvendo infecções com C. burnetii (KHAVIN; TABIBZADEH, 1988; YOSHIIE et al., 1999; VOTH; HOWE; HEINZEN, 2007; CALVERLEY et al., 2012; GRAHAM et al., 2013; CUNHA et al., 2015; SOLTYSIAK; VAN SCHAIK; SAMUEL, 2015). Outros modelos incluem: macrófagos derivados de monócitos humanos, células da linhagem monocítica humana THP-1 e células Vero (derivadas de rim de macaco verde) (BURTON et al., 1978; DELLACASAGRANDE et al., 1999; ZAMBONI; MORTARA; RABINOVITCH, 2001; GHIGO et al., 2002; BENOIT et al., 2008; SHANNON; HEINZEN, 2008; HOWE et al., 2010). É importante ressaltar que, apesar da grande variedade de modelos de estudo com C. burnetii, muitos dos trabalhos focam apenas na suscetibilidade ao patógeno e não trazem evidências sobre quais os mecanismos estariam por trás desses fenômenos. Justamente por isso, nesse trabalho buscamos não apenas caracterizar um modelo relevante, mas também entender quais são os mecanismos por trás da suscetiblidade à C. burnetii.

Além da escolha do modelo de estudo, é importante ainda optar por um método eficiente para análise da suscetibilidade das células à infecção por C. burnetii. Tradicionalmente, a suscetibilidade a essa bactéria foi por muito tempo avaliada através da 
estimativa do número de vacúolos parasitóforos nas células infectadas, bem como pela quantificação da intensidade de fluorescência em células infectadas marcadas com DAPI com o auxílio de microscópio de fluorescência confocal, o qual está diretamente correlacionado com a multiplicação do patógeno (ZAMBONI et al., 2001; ZAMBONI et al., 2002). Entretanto, essa metodologia pode incorrer em imprecisões dependendo da experiência e critérios utilizados por cada observador. Por exemplo, já foi descrito que ao menos para macrófagos alveolares humanos C. burnetii forma mais frequentemente múltiplos vacúolos pequenos ao invés de um grande vacúolo fusogênico (GRAHAM et al., 2013). Dessa forma, para que não houvesse uma diferença entre os observadores quanto à análise de suscetibilidade pelo critério "número de vacúolos", seria necessário uma padronização prévia quanto à contagem de vacúolos de tamanhos e/ou graus de fusogenicidade distintos. Sendo assim, para evitar esses problemas, nesse trabalho optamos pela quantificação do DNA genômico bacteriano por PCR quantitativo (qPCR) como metodologia de análise da suscetibilidade dos macrófagos à infecção por C. burnetii. Esse é um método mais sensível e reprodutível, que não depende dos critérios de observação do experimentador e que já foi descrito como sendo eficiente para estudos com essa bactéria (BRENNAN; SAMUEL, 2003; KLEE et al., 2006a; KLEE et al., 2006b).

É importante ressaltar, ainda, que para a realização deste trabalho optamos por utilizar a forma avirulenta para seres humanos de C. burnetii derivada da cepa Nine Mile, conhecida

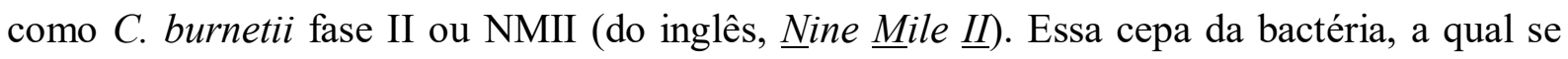
diferencia das formas virulentas devido ao tipo de LPS que apresenta, possui um clone que contém uma grande deleção cromossomal que resultou na impossibilidade de retornar a um estado completo de virulência, o que a torna apropriada para realização de estudos em condições de biossegurança nível 2. É importante salientar também que, apesar de apresentar essa deleção, essa bacteria não apresenta diferenças quanto ao tráfego intracelular, a cinética de replicação e a capacidade de restrição da sua multiplicação por parte dos hospedeiros quando em comparação com formas virulentas de C. burnetii da cepa Nine Mile, chamadas de C. burnetii fase I ou NMI (do inglês, Nine Mile I).(AMANO; WILLIAMS, 1984; HACKSTADT, 1996; HOWE et al., 2010; GRAHAM et al., 2013; LARSON et al., 2016).

Considerando então a importância biomédica de C. burnetii e a necessidade de uma melhor compreensão dos mecanismos envolvidos nas diferenças de suscetibilidade e no controle da infeção com esse patógeno por macrófagos, nosso trabalho buscou determinar um modelo primário de macrófagos que fosse adequado e relevante e que permitisse avaliar as 
interações patógeno-hospedeiro nas infecções por C. burnetii. Para isso, optamos inicialmente por utilizar macrófagos murinos derivados de medula óssea em fundo gênico C57BL/6 como modelo celular, tendo em vista a facilidade de obtenção dessas células e o grande número de camundongos geneticamente modificados disponíveis (MARIM et al., 2010). Foi escolhida a bactéria $C$. burnetii cepa NMII que apresenta a deleção genômica como modelo de infecão, pela possibilidade de se realizar os experimentos sem necessidade de uma estrutura de biossegurança com maior complexidade do que a disponível em nosso laboratório. Por fim, determinamos a utilização de qPCR como método principal para análise da suscetibilidade, considerando sua eficácia, sensibilidade e reprodutibilidade (BRENNAN; SAMUEL, 2003; KLEE et al., 2006a; KLEE et al., 2006b).

Primeiramente, testamos a suscetibilidade de BMDMs de camundongos C57BL/6 frente à infecção por C. burnetii fase II e comparamos com BMDMs da linhagem A/J. Em concordância com dados da literatura, vimos que as células em fundo gênico C57BL/6 controlaram a replicação da bactéria, enquanto que aquelas no fundo gênico $\mathrm{A} / \mathrm{J}$ foram permissíveis ao crescimento bacteriano, evidenciado pelo aumento na quantificação do DNA genômico de C. burnetii ao longo dos 12 dias de infecção (Figura 5). Uma vez que a maioria dos camundongos geneticamente modificados encontram-se no fundo gênico C57BL/6 e este se mostrou restritivo à replicação de C. burnetii, buscamos outro modelo de macrófagos primários que permitissem o crescimento bacteriano. Demonstramos que AMs são altamente suscetíveis à replicação de C. burnetii fase II, independente do fundo gênico do camundongo (Figura 6), o que nos sugeriu que esse poderia ser um modelo relevante para se estudar as interações patógeno-hospedeiro nas infecções com essa bactéria. Vale ressaltar que trabalhos anteriores já haviam descrito que macrófagos alveolares de primatas e macrófagos alveolares humanos são permissivos à replicação de C. burnetii, assim como observamos em nosso modelo murino (KHAVIN; TABIBZADEH, 1988; YOSHIIE et al., 1999; VOTH; HOWE; HEINZEN, 2007; CALVERLEY et al., 2012; GRAHAM et al., 2013; SOLTYSIAK; VAN SCHAIK; SAMUEL, 2015). Isso sugere que a suscetibilidade à infecção possa estar mais relacionada com o tipo de macrófago em si do que com a espécie ou linhagem analisada, ou seja, que essa suscetibilidade aumentada seja uma característica inerente ao macrófago alveolar. Apesar desses achados, os trabalhos anteriores não se aprofundaram na busca pelos mecanismos que explicassem essa permissividade aumentada apresentada pelos AMs, um ponto fundamental para compreensão da resposta à infecção por C. burnetii. Isso nos levou 
não apenas a buscar e caracterizar AMs como um modelo de estudos relevante, mas ir mais a fundo na busca dos mecanismos que explicassem a suscetibilidade ao patógemo.

Por meio do uso de microscopia de fluorescência multifóton e microscopia eletrônica de transmissão, fornecemos evidências visuais de que C. burnetii fase II prontamente replica no interior de AMs (Figuras 7 e 8). Diferentemente da utilização de microscopia de fluorescência como metodologia para quantificar a suscetibilidade ao patógeno, como descrito por Zamboni e colaboradores $(2001,2002)$, nossa utilização desse método se deu apenas de forma qualitativa como ferramenta para demonstrar a multiplicação de C. burnetii. Mostramos ao longo dos 12 dias de infecção através do aumento na intensidade da fluorescência decorrente da marcação da bactéria corada com anticorpos, assim como da bactéria expressando $m$ Cherry, que macrófagos alveolares murinos são altamente permissíveis à $C$. burnetii de uma forma tal que a bactéria passa a ocupar completamente todo o espaço celular após nove dias de infecção (Figura 7C). O aumento na intensidade da fluorescência proveniente da bactéria expressando $m$ Cherry demonstra ainda que a bactéria se encontra viva e metabolicamente ativa, reforçando a viabilidade de AMs como modelo de estudo. Além disso, demonstramos através da marcação da proteína LAMP-1 e da visualização da célula infectada por microscopia eletrônica de transmissão que a bactéria replica no interior de seu vacúolo característico. A visualização de grandes quantidades da forma variante celular grande de C. burnetii no interior dos vacúolos também corrobora a hipótese de que a bactéria está replicando no interior dos AMs, visto que essa é a forma metabolicamente ativa e replicante do patógeno (COLEMAN et al., 2004).

Com base em nossas observações indicando que AMs murinos são altamente permissivos à replicação de C. burnetii fase II in vitro em comparação com BMDMs murinos, os quais se mostram resistentes à infecção, e visando elucidar quais os mecanismos por trás dessa suscetibilidade aumentada, hipotetizamos que essa diferença de suscetibilidade poderia ser decorrente da aquisição de padrões distintos de polarização entre esses tipos celulares. Dados da literatura destacam a importância do estado de polarização de macrófagos e monócitos após o encontro com C. burnetii para o desenvolvimento de respostas que podem levar ao controle da infecção ou à sobrevivência da bacteria nos hospedeiros (AMARA; BECHAH; MEGE, 2012). Em conjunto com esses dados, evidências recentes indicam que AMs são originados a partir de monócitos fetais de vida longa que migram para os pulmões e lá permanecem como macrófagos alveolares residentes, sendo mantidos através de autorenovação, muito mais do que uma manutenção envolvendo a substituição das células mortas 
por novos monócitos circulantes derivados de células da medula óssea (GUILLIAMS et al., 2013). Como resultado, o microambiente tecidual ao qual essas células estariam expostas seria muito diferente do microambiente em que se encontrariam os BMDMs, de forma que diferenças epigenéticas e transcriptômicas seriam impressas nessas células resultando em um padrão de resposta fenotípico distinto entre elas, de acordo com o que observamos (GORDON et al., 2014; GOSSELIN et al., 2014; LAVIN et al., 2014).

Para testarmos a hipótese de que diferenças no estado de polarização dos macrófagos seriam o mecanismo responsável pela alta permissividade dos AMs murinos à infecção por $C$. burnetii fase II, avaliamos a expressão de genes comumente associados com padrões de polarização do tipo M1 ou M2 por meio de RT-PCR. De forma geral, macrófagos que apresentam polarização em um perfil M1 produzem grandes quantidades de citocinas próinflamatórias e são considerados microbicidas, enquanto que macrófagos polarizados em um perfil M2 são geralmente anti-inflamatórios e permitem a sobrevivência de patógenos (MANTOVANI et al., 2004; MANTOVANI et al., 2013; MURRAY, 2017; SHAPOURIMOGHADDAM 2018). Nossos resultados mostraram que AMs murinos apresentam níveis mais elevados de expressão de genes relacionados com a polarização no padrão M2, como Arginase-1, Fizz1, Ym1 e IL-4, enquanto que em BMDMs a expressão de genes relacionados com o padão M1, como NOS2, IFN- $\gamma$, TNF- $\alpha$ e TLR2, é mais elevada. É interessante ressaltar que essa diferença entre AMs e BMDMs foi observada mesmo sem a infecção por C. burnetii, e a infecção com esse patógeno apenas acentuou e reforçou o que fora obtido anteriormente (Figura 9). Considerando a existência de dois modelos, sendo um deles o da ontogenia e o outro o da plasticidade (BONNARDEL. GUILLIAMS, 2018) isso fortaleceria a hipótese de que para a determinação do estado de polarização do macrófago e, consequentemente, para o desempenho de suas funções especializadas, a ontogenia seria prevalente sobre a plasticidade. Em outras palavras, o fato de que AMs e BMDMs murinos submetidos às mesmas condições in vitro apresentam um perfil de expressão gênica que se relaciona com padrões distintos de polarização sugere que, para a determinação do estado de polarização do macrófago, de onde a célula veio seria mais importante do que o microambiente ao qual ela estaria sujeita.

Outra metodologia utilizada nesse trabalho para confirmar a hipótese de que AMs apresentam um perfil de polarização do tipo M2 que os tornam mais permissivos à replicação de C. burnetii fase II in vitro foi a fenotipagem dos marcadores de superfície dessas células por meio de citometria de fluxo. Confirmando os dados obtidos com RT-PCR, AMs mostraram expressão aumentada de moléculas de superfície consideradas como marca 
registrada do perfil de polarização M2, sendo elas o receptor de manose (CD206) e o receptor dectina-1, quando comparados com BMDMs (Figura 10). Nossos resultados vão de acordo com o que já foi descrito na literatura para macrófagos alveolares humanos, nos quais $C$. burnetii induz a ativação de um perfil atípico de polarização M2 (BENOIT et al., 2008). Outros trabalhos também relataram essa permissividade à replicação de C. burnetii em macrófagos alveolares primários humanos e macrófagos residentes murinos, entretanto não buscaram determinar qual seria o mecanismo responsável por essa suscetibilidade (CALVERLEY et al., 2012; GRAHAM et al., 2013). É possível que para esses trabalhos, assim como observado no nosso trabalho e por Benoit e colaboradores (2008), essa permissividade seja resultado de um perfil de polarização do tipo M2. Vale destacar que, na realidade, os padrões de polarização M1 e M2 não são únicos, e sim representam dois extremos de um contínuo de estados funcionais polarizados. O padrão M2 subdivide-se em M2a, M2b, M2c e, para camundongos, existe ainda o estado M2d. Cada um deles é induzido frente a estímulos distintos e, como resultado, apresentam funções especializadas particulares. Considerando o padrão de expressão de genes e moléculas de superfície obtido em nossos resultados para AMs murinos frente à infecção por C. burnetii fase II in vitro, é possível sugerir que nesse caso ocorre uma polarização no perfil M2a ou M2c. Os níveis elevados de expressão de Arginase-1 e receptor de manose, assim como o desempenho de funções relacionadas com o perfil de resposta mais do tipo II e mais anti-inflamatório suportam essa hipótese. Em conjunto, essas características apresentadas pelos AMs possibilitam a sobrevivência do patógeno (MANTOVANI et al., 2004). Estudos avaliando uma maior quantidade de marcadores associados com padrões de polarização poderão determinar a qual subgrupo específico do padrão M2 se enquadram os AMs murinos após infecção com $C$. burnetii fase II.

Corroboramos ainda a hipótese de que a alta permissividade dos AMs murinos observada em nossos experimentados era decorrente de uma polarização em perfil M2 por meio da infecção de células derivadas de camundongos deficientes para IL-4. Já está bem estabelecido na literatura que IL-4 consiste em uma das mais importantes citocinas para a indução do estado de polarização M2, juntamente com IL-13, via ativação de STAT6 pelo receptor IL-4Ra (GORDON, 2003; MANTOVANI et al., 2013; MURRAY, 2017; SHAPOURI-MOGHADDAM 2018). Sendo assim, era esperado que AMs derivados de camundongos $\mathrm{Il}-4^{-/-}$apresentassem um prejuízo na polarização em perfil M2 quando em comparação com as mesmas células derivadas de camundongos selvagens. Nossos resultados 
confirmaram essa hipótese, com AMs derivados de camundongos $\mathrm{Il}-4^{-/}$se mostrando significativamente mais restritivos à replicação de C. burnetii fase II do que AMs derivados de camundongos WT (Figura 11C).

Para fortalecer a relevância de AMs murinos como um novo modelo primário de macrófagos para estudos com infecções in vitro por C. burnetii fase II, como proposto nesse trabalho, infectamos AMs derivados de camundongos Ifng ${ }^{-/}$e $\mathrm{Nos}^{-/}$como prova de princípio. Diversos trabalhos na literatura mostram que a produção de óxido nítrico e espécies reativas intermediárias de nitrogênio são de extrema importância na resposta immune contra patógenos respiratórios, com NO apresentando efeitos citotóxicos em níveis elevados (NATHAN; SHILOH, 2000). Além disso, já está bem estabelecido que NO participa da restrição da replicação intracelular de C. burnetii (HOWE et al., 2002; ZAMBONI; RABINOVITCH, 2003; BRENNAN et al., 2004; ZAMBONI, RABINOVITCH, 2004; HILL; SAMUEL, 2011), sendo assim a ausência dessa molécula resultaria em uma maior permissividade à multiplicação da bactéria. Isso foi de fato observado em nossos estudos (Figura 11A). A ausência de IFN- $\gamma$ também deveria levar a um aumento na suscetibilidade à C. burnetii, visto que essa molécula não só participa da indução de um estado de polarização no perfil M1, mas também é fundamental para a produção de NO. Como esperado, AMs derivados de camundongos Ifng $^{-/}$permitiram a replicação de maiores quantidades da bactéria (Figura 11B). Nesse trabalho, demonstramos também que AMs derivados de camundongos C57BL/6 suportam a replicação intracelular de C. burnetii e que essa replicação ocorre de maneira comparável a aquela observada em linhagens celulares imortalizadas que são sabidamente altamente suscetíveis à $C$. burnetii, como células Vero e células THP-1 (Figura 12) (BURTON et al., 1978; DELLACASAGRANDE et al., 1999; ZAMBONI; MORTARA; RABINOVITCH, 2001; GHIGO et al., 2002; BENOIT et al., 2008; SHANNON; HEINZEN, 2008; HOWE et al., 2010). Em conjunto, esses resultados validaram a utilização de AMs murinos como um modelo celular relevante para os estudos in vitro com a infecção por $C$. burnetii fase II.

Por fim, vale ressaltar que em oposição ao que observamos em nossos experimentos e ao que já estava descrito na literatura, Cockrell e colaboradores (2017) relataram um crescimento de quase três logs de C. burnetii fase II em BMDMs derivados de camundongos no fundo gênico restritivo C57BL/6. Esses pesquisadores explicam as diferenças observadas com base na fonte de M-CSF utilizada em ambos os estudos: enquanto nosso grupo e os demais trabalhos da literatura utilizaram meio condicionado de células L929 como a fonte de 
M-CSF, nos experimentos publicados por Cockrell e colaboradores (2017) foi utilizado MCSF recombinante murino. Ainda segundo os autores, o meio condicionado de células L929 conteria componentes não caracterizados que poderiam interferir no estado de ativação do macrófago, tais como quantidades variáveis de interferons do tipo I, o que refletiria diretamente na permissividade à infecção uma vez que o estado de polarização adotado pelos macrófagos é um mecanismo essencial da resposta imune à $C$. burnetii e interferons do tipo I são fortes polarizadores do padrão M1 (MANTOVANI et al., 2004; AMARA; BECHAH; MEGE, 2012; BISWAS et al., 2012; LOCATI; MANTOVANI; SICA, 2013; MURRAY et al., 2014; MURRAY, 2017; SHAPOURI-MOGHADDAM et al., 2018).

Os resultados obtidos por Cockrell e colaboradores (2017) não invalidam nossos achados de que AMs apresentam um perfil de polarização do tipo M2 que os tornam altamente permissivos à replicação de C. burnetii fase II in vitro. Entretanto, eles nos levam a pensar que talvez BMDMs também possam ser de fato utilizados como outra opção de modelo primário de macrófagos murinos para estudos de suscetibilidade a essa bactéria, desde que para isso seja utilizada uma fonte de M-CSF que não contenha outros componentes que possam potencialmente alterar o estado de polarização dos macrófagos. Por fim, nosso trabalho apresentou e caracterizou macrófagos alveolares murinos como um modelo relevante de células primárias altamente suscetíveis à replicação de $C$. burnetii fase II in vitro que pode ser empregado em estudos visando um melhor entendimento entre as relações patógenohospedeiro que acontecem nas infecções por essa bactéria. 


\section{SUMÁRIO}

- Macrófagos derivados de medula óssea (BMDMs) de camundongos C57BL/6 são mais restritivos à replicação de $C$. burnetii fase II do que aqueles derivados de camundongos $\mathrm{A} / \mathrm{J}$.

- Macrófagos alveolares (AMs) no fundo gênico restritivo C57BL/6 são permissivos à replicação de C. burnetii fase II, em contraste com o que ocorre para BMDMs dessa mesma linhagem.

- AMs derivados de camundongos $\mathrm{C} 57 \mathrm{BL} / 6$ são tão suscetíveis à replicação de $C$. burnetii fase II quanto AMs derivados de camundongos A/J.

- A replicação de C. burnetii fase II em AMs ocorre dentro dos vacúolos parasitóforos característicos e pode ser observada por meio de microscopia confocal de fluorescência e microscopia eletrônica de transmissão.

- AMs murinos apresentam um perfil de polarização do tipo M2, enquanto para BMDMs é observado um perfil de polarizaçao do tipo M1.

- AMs murinos apresentam maior expressão de genes relacionados com o padrão M2 de polarização do que BMDMs murinos, tanto em células não infectadas quanto em células infectadas com C. burnetii fase II.

- A fenotipagem de AMs murinos mostra uma maior expressão de moléculas de superfície relacionadas com o padrão M2 de polarização do que a observada em BMDMs murinos, tanto em células não infectadas quanto em células infectadas com C. burnetii fase II.

- AMs em fundo gênico C57BL/6 deficientes para NOS2 e IFN- $\gamma$ são mais suscetíveis à replicação de C. burnetii fase II.

- AMs em fundo gênico C57BL/6 deficientes para IL-4 são mais restritivos à replicação de C. burnetii fase II.

- A polarização em um padrão M1 ou M2 está relacionada à alta permissividade de AMs murinos à infecção por C. burnetii fase II em comparação com BMDMs murinos.

- A suscetibilidade aumentada de AMs murinos à infecção por C. burnetii fase II é comparável com aquela observada para células Vero e células THP-1. 
- AMs murinos constituem um modelo primário de células suscetíveis altamente relevante para investigações acerca das interações patógeno-hospedeiro envolvendo a infecção com C. burnetii fase II in vitro. 


\section{CONCLUSÃO}

Os dados obtidos permitem concluir que macrófagos alveolares murinos compreendem um modelo celular primário altamente permissivo à replicação da bactéria $C$. burnetii fase II e que essa suscetibilidade aumentada deve-se à indução de um estado de polarização do tipo M2. Dessa forma, nossos achados indicam que os macrófagos alveolares murinos podem ser utilizados como um relevante modelo de estudos das interações patógenohospedeiro em células primárias frente à infecção in vitro por C. burnetii fase II, permitindo inclusive a utilização de células derivadas de camundongos geneticamente modificados no fundo gênico C57BL/6. 


\section{REFERÊNCIAS BIBLIOGRÁFICAS ${ }^{1}$}

AGUILERA, M. et al. Actin dynamics and Rho GTPases regulate the size and formation of parasitophorous vacuoles containing Coxiella burnetii. Infection and Immunity, v. 77, p. 4609-4620, 2009.

AKIRA, S.; TAKEDA, K. Toll-like receptor signalling. Nature Reviews Immunology, v. 4, n. 7, p. 499-511, 2004.

AMANO, K.; WILLIAMS, J. C. Chemical and immunological characterization of lipopolysaccharides from Phase I and Phase II Coxiella burnetii. Journal of Bacteriology, v. 160, p. 994-1002, 1984.

AMARA, A. B.; BECHAH, Y.; MEGE, J. L. Immune Response and Coxiella burnetii Ivasion. Advances in Experimental Biology and Medicine, v. 984, p. 287-298, 2012.

ANDERSON, A. et al. Diagnosis and management of $\mathrm{Q}$ fever - United States, recommendations from $\mathrm{CDC}$ and the $\mathrm{Q}$ Fever Working group. Morbidity and Mortality Weekly Report. Recommendations and Reports, v. 62, p. 1-30, 2013.

ANDOH, M. et al. T cells are essential for bacterial clearance, and gamma interferon, tumor necrosis factor alpha, and B cells are crucial for disease development in Coxiella burnetii infection in mice. Infection and Immunity, v. 75, p. 3245-3255, 2007.

ARRICAU-BOUVERY, N. et al. Molecular characterization of Coxiella burnetii isolates by infrequent restriction site-PCR and MLVA typing. BMC Microbiology, v. 6, p. 38, 2006.

BACA, O. G.; KLASSEN, D. A.; ARAGON, A. S. Entry of Coxiella burnetii into host cells. Acta Virologica, v. 37, p. 143-155, 1993.

BARRY, A. O. et al. Impaired stimulation of p38alpha-MAPK/Vps41-HOPS by LPS from pathogenic Coxiella burnetii prevents trafficking to microbicidal phagolysosomes. Cell Host Microbe, v. 12, p. 751-763.

BEARE, P. A. et al. Dot/Icm type IVB secretion system requirements for Coxiella burnetii growth in human macrophages. mBio, v. 2, p e00175-11, 2011.

BENOIT, M. et al. Coxiella burnetii, the agent of $\mathrm{Q}$ fever, stimulates an atypical M2 activation program in human macrophages. European Journal of Immunology, v. 38, p. 1065-1070, 2008.

BENOIT, M. et al. The uptake of apoptotic cells drives Coxiella burnetii replication and macrophage polarization: a model for Q fever endocarditis. PLoS Pathogens, v. 4, n. 5, p. e1000066, 2008.

BENOIT, M.; DESNUES, B.; MEGE, J. L. Macrophage polarization in bacterial infections. Journal of Immunology, v. 181, p. 3733-3739, 2008.

${ }^{11}{ }^{1}$ De acordo com a Associação Brasileira de Normas Técnicas (ABNT NBR 6023) 
BERON, W. et al. Coxiella burnetii localizes in a Rab7-labeled compartment with autophagic characteristics. Infection and Immunity, v. 70, p. 5816-5821, 2002.

BISWAS, S. K. et al. Macrophage polarization and plasticity in health and disease. Immunologic Research, n. 53, v. 1-3, p. 11-24, 2012.

BONNARDEL, J.; GUILLIAMS, M. Developmental control of macrophage function. Current Opinion in Immunology, v. 50, p. 64-74, 2018.

BRADLEY, W. P. et al. Primary role for Toll-like receptor-drive tumor necrosis fator rather than cytosolic immune detection in restricting Coxiella burnetii phase II replication within mouse macrophages Infection and Immunity, v. 84, p. 998-1015, 2016.

BRENNAN, R. E. et al. Both indicible nitric oxide syntahse and NADPH oxidase contribute to the controlo f virulent phase I Coxiella burnetii infections. Infection and Immunity, v. 72, p. 6666-6675, 2004.

BRENNAN, R. E.; SAMUEL, J. E. Evaluation of Coxiella burnetii Antibiotic Susceptibilities by Real-Time PCR Assay. Journal of Clinical Microbiology, v. 41, n. 5, p. 1869-1874, 2003.

BURNET, F. M.; FREEMAN, M. Experimental studies on the virus of "Q" fever. Reviews of Infectious Diseases, v. 5, n. 4, p. 800-8, 1983.

BURTON, P. R. et al. Some ultrastructural effects of persistente infections by the rickettsia Coxiella burnetii in mouse L cells and green mondey kidney (Vero) cells. Infection and Immunity, v. 21, n. 2, p. 556-66, 1978.

CALVERLET, M. et al. Resident alveolar macrophages are susceptible to and permissive of Coxiella burnetii infection. PLoS One, v. 7, p. e51941, 2012.

CAMPOY, E. M.; MANSILLA, M. E.; COLOMBO, M. I. Endocytic SNAREs are involved in optimal Coxiella burnetii vacuole development. Cellular Microbiology, v. 15, p. 922e41, 2013.

CAMPOY, E. M.; ZOPPINO, F. C. M.; COLOMBO, M. I. The early secretory pathway contributes to the growth of the Coxiella replicative niche. Infection and Immunity, v. 79, n. 1, p. 402-13, 2011.

CAPO, C. et al. Subversion of monocyte functions by Coxiella burnetii impairment of the cross-talk between $\alpha v \beta 3$ integrin and CR3. Journal of Immunology, v. 163, p. 6078-6085, 1999.

CAPO, C.; MEGE, J. L. Role of Innate and Adaptive Immunity in the Control of Q Fever. Advances in Experimental Biology and Medicine, v. 984, p.273-286, 2012.

CAREY, K. L. et al. The Coxiella burnetii Dot/Icm system delivers a unique repertoire of type IV effectors into host cells and is required for intracellular replication. PLoS Pathogens, v. 7, p. e1002056. 
CELADA, A. et al. Evidence for a gamma-interferon receptor that regulates macrophage tumoricidal activity. Journal of Experimental Medicine, v. 160, p. 55-74, 1984.

CHISTIAKOV, D. A.; BOBRYSHEV, Y. V.; OREKHOV, A. N. Changes in transcriptome of macrophages in atherosclerosis. Journal of Cellular and Molecular Medicine, v. 19, n. 6, p. 1163-73, 2015.

COCKRELL, D. C. et al. Robust growth of avirulent phase II Coxiella burnetii in bone marrow-derivevd murine macrophages. PLoS ONE, v. 12, n. 3, p. e0173528, 2017.

COLEMAN, S. A. et al. Temporal analysis of Coxiella burnetii morphological differentiation. Journal of Bacteriology, v. 186, p. 7344-7352, 2004.

COSTA, P. S.; BRIGATTE, M. E.; GRECO, D. B. Questing one Brazilian query: reporting 16 cases of Q fever from Minas Gerais, Brazil. Revista do Instituto de Medicina Tropical de São Paulo, v. 48, n. 1, p.5-9, 2006.

CRABILL, E. et al. Dot/Icm-Translocated Proteins Important for Biogenesis of the Coxiella burnetii-Containing Vacuole Identified by Screening of an Effector Mutant Sublibrary. Infection and Immunity, v. 88, n. 4, p. e00758-17, 2018.

CREAGH, E. M.; O'NEILL, L. A. TLRs, NLRs and RLRs: a trinity of pathogen sensors that co-operate in innate immunity. Trends in Immunology, v. 27, n. 8, p. 352-7, 2006.

CUNHA, L. D. et al. Inhibition of inflammasome activation by Coxiella burnetii type IV secretion system effector IcaA. Nature Communications, v. 6, p. 10205, 2015.

CUNHA, L. D.; ZAMBONI, D. S. Subversion of inflammasome activation and pyroptosis by pathogenic bacteria. Frontiers in Cellular and Infection Microbiology, v. 3, p. 76, 2013.

DELLACASAGRANDE, J. et al. IFN- $\gamma$ mediated control of Coxiella burnetii survival in monocytes: the role of cell apoptosis and TNF. Journal of Immunology, v. 1950, n. 162, p. 2259-2264, 1999.

DERRICK, E. H. "Q" fever, a new fever entity: clinical features, diagnosis and laboratory investigation. Reviews of Infectious Diseases, v. 5, n. 4, p. 790-800, 1983.

DINAKAR, C. et al. Differential regulation of human blood monocyte and alveolar macrophage inflamatory cytokine production by nitric oxide. Annals of Ashtma Immunology, v. 82, p. 217-222, 1999.

DOROTHÉE, D. et al. Tumor-associates leukemia inhibitory factor and IL-6 skew monocyte differentiation into tumor-associated macrophage-like cells. Blood, v. 110, p. 4319-4330, 2007.

DOYLE, A. G. et al. Interleukin-13 alters the activation state of murine macrophages in vitro: comparison with interleukin-4 and interferon-gamma. European Journal of Immunology, v. 24, p. 1441-5, 1994. 
DYER, R. E. A filter passing infectious agent isolated from ticks IV Human infection. Public Health Reports, v. 53, p. 2277-2282, 1938.

DYER, R. E. Similarity of Australian "Q" fever and a disease caused by na infectious agent isolated from ticks in Montana. Public Health Reports, v. 54, p. 1229-1237, 1939.

ELDIN, C. et al. From Q fever to Coxiella burnetii infection: a paradigm change. Clinical Microbiology Reviews, v. 30, p. 115-190, 2017.

ENSERINK, M. Questions abound in Q-fever explosion in Netherlands. Science, v. 327, n. 5963, p. 266-8, 2010.

FERNANDES, T. D. et al. Murine Alveolar Macrophages Are Highly Susceptible to Replication of Coxiella burnetii Phase II In Vitro. Infection and Immunity, v. 84, n. 9, p. 2439-48, 2016.

GHIGO, E. et al. Coxiella burnetii survival in THP-1 monocytes involves the impairment of phagosome maturation: IFN- $\gamma$ mediates its restoration and bacterial killing. Journal of Immunology, v. 69, p. 4488-4495, 2002.

GHIGO, E. et al. Link between impaired maturation of paghosomes and defective Coxiella burnetii killing in patients with chronic Q fever. Journal of Infectious Diseases, n. 190, p. 1767-1772, 2004.

GHIGO, E. et al. Intracellular life of Coxiella burnetii in macrophages. Annals of New York Academy of Science, v. 66, p. 55-66, 2009.

GHIGO, E.; COLOMBO, M. I.; HEINZEN, R. A. The Coxiella burnetii Parasitophorous Vacuole. Advances in Experimental Biology and Medicine, v. 984, p. 141-169, 2012.

GILK, S. D. Role of Lipids in Coxiella burnetii Infection. Advances in Experimental Biology and Medicine, v. 984, p. 198-213, 2012.

GILK, S. D.; BEARE, P. A.; HEINZEN, R. A. Coxiella burnetii expresses a functional Delta24 sterol reductase. Journal of Bacteriology, v. 192, p. 6154e9, 2010.

GINHOUX, F. et al. New insights into the multidimensional concept of macrophage ontongeny, activation and function. Nature Immunology, v. 17, n. 1, p. 34-40, 2016.

GLASS, C. K.; NATOLI, G. Molecular control of activation and priming in macrophages. Nature Immunology, v. 17, n. 1, p. 26-33, 2016.

GLAZUNOVA, O. et al. Coxiella burnetii Genotyping. Emergent Infectious Diseases, v. 11, n. 8, p. 1211-7, 2005.

GRAHAM J. G. et al. Virulent Coxiella burnetii pathotypes productively infect primary human alveolar macrophages. Celullar Microbiology, v. 15, p. 1012-1025, 2013. 
GORDON, S. Alternative activation of macrophages. Nature Reviews Immunology, v. 3, p. 23-35, 2003.

GORDON, S. et al. Macrophage heterogeneity in tissues: phenotypic diversity and functions. Immunological Reviews, v. 262, p. 36-55, 2014.

GOSSELIN, D. et al. Environment drives selection and function of enhancers controlling tissue-specific macrophage identities. Cell, v. 159, p. 1327-1340.

GUILLIAMS, M. et al. Alveolar macrophages develop from fetal monocytes that differentiate into longlived cells in the first week of life via GM-CSF. Journal of Experimental Biology, v. 210, p. 1977-1992, 2013.

GUO, H.; CALLAWAY, J. B.; TING, J. P. Inflammasomes: mechanism of action, role in disease, and therapeutics. Nature Medicine, v. 21, n. 7, p. 677-87, 2015.

GUTIERREZ, M. G. et al. Autophagy induction favours the generation and maturation of the Coxiella-replicativa vacuoles. Cellular Microbiology, v. 7, n. 7, p. 981-993, 2005.

HACKSTADT, T. Biosafety concerns and Coxiella burnetii. Trends in Microbiology, v. 4, p. 341-342, 1996.

HACKSTADT, T. Steric hindrance of antibody binding to surface proteins of Coxiella burnetii by Phase II lipopolysaccharide. Infection and Immunity, v. 56, p. 802-807, 1998.

HAMASAKI, M. et al. Autophagosomes from at ER-mitochondria contact sites. Nature, v. 495, p. 389e93, 2013.

HARRIS, R. J. et al. Long-term persistence of Coxiella burnetii in the host after primary Q fever. Epidemiology and Infection, v. 124, p. 543-549, 2000.

HECHEMY, K. E. History and prospects of Coxiella burnetii research. Advances in Experimental Biology and Medicine, v. 984, p. 1-11, 2012.

HEINZEN, R. A. et al. Differential interaction with endocytic and exocytic pathways distinguish parasitophorous vacuoles of Coxiella burnetii and Chlamydia trachomatis. Infection and Immunity, v. 64, n. 3, p.796-809, 1996.

HENRY, R. M. et al. The uniformity of phagosome maturation in macrophages. Jounral of Cellular Microbiology, v. 164, p. 185-194, 2004.

HILL, J.; SAMUEL, J. E. Coxiella burnetii acid phosphatase inhibits the release of reactive oxygen intermediates in polymorphonuclear leukocytes. Infection and Immunity, v. 79, p. 414-420, 2011.

HONSTETTRE, A. et al. Lipopolysaccharide from Coxiella burnetii is involved in bacterial phagocytosis, filamentous actin reorganization, and inflammatory responses through Toll-like receptor 4. Journal of Immunology, v. 172, p. 3695-3703, 2004. 
HORNSTRA, H. M. et al. Rapid Typing of Coxiella burnetii. PLoS ONE, v. 6, n. 11, p. e26201, 2011.

HOWE, D. et al. Maturation of the Coxiella burnetii parasitophorous vacuole requires bacterial protein synthesis but not replication. Cellular Microbiology, v. 5, n. 7, p. 469-480, 1993.

HOWE, D. et al. Nitric oxide inhibits Coxiella burnetii replication and parasitophorous vacuole maturation. Infection and Immunity, v. 70, p. 5140-5147, 2002.

HOWE, D. et al. Fusogenicity of the Coxiella burnetii parasitophorous vacuole. Annals of the New York Academy of Sciences, v. 990, p. 556-562, 2003a.

HOWE, D. et al. Maturation of the Coxiella burnetii parasitophorous vacuole requires bacterial protein synthesis but not replication. Cellular Microbiology, v. 5, p. 469e80, 2003 b.

HOWE, D. et al. Coxiella burnetii phase I and phase II variants replicate with similar kinetics in degradative phagolysosome-like compartments of human macrophages. Infection and Immunity, v. 78, p. 3465-3474, 2010.

HOWE, D.; MALLAVIA, L. P. Coxiella burnetii infection increases transferrin receptors on J774A. 1 cells. Infection and Immunity, v. 67, p. 3236-3241, 1999.

HOWE, D.; HEINZEN, R. A. Coxiella burnetii inhabits a cholesterol-rich vacuole and influences cellular cholesterol metabolism. Cellular Microbiology, v. 8, p. 496e507, 2006.

HUSSAIN, S. K. et al. Host kinase activity is required for Coxiella burnetii parasitophorous vacuole formation. Frontiers in Microbiology, v. 1, p. 137, 2010.

HUSSAIN, S. K.; VOTH, D. E. Coxiella Subversion of Intracellular Host Signaling. Advances in Experimental Biology and Medicine, v. 984, p. 131-140, 2012.

IHNATKO, R.; SHAW, E.; TOMAN, R. Proteome of Coxiella burnetii. Advances in Experimental Biology and Medicine, v. 984, p. 105-130, 2012.

ITAKURA, E.; KISHI-ITAKURA, C.; MIZUSHIMA, N. The hairpin-type tail-anchored SNARE syntaxin 17 targets autophagosomes for fusion with endosomes/lysosomes. Cell, v. 151, p. 1256e69, 2012.

KAWAI, T.; AKIRA, S. The role of pattern-recognition receptors in innate immunity: update on Toll-like receptors. Nature Immunology, v. 11, n. 5, p. 373-84, 2010.

KHAVKIN, T.; TABIBZADEH, S. S. Histologic, immunofluorescence, and eletron microscopy study of infectious process in mouse lung after intranasal challenge with Coxiella burnetii. Infection and Immunity, v. 56, p. 1792-1799, 1988.

KLEE, S. R. et al. Highly sensititive real-time PCR for specific detection and quantification of Coxiella burnetii. BMC Microbiology, v. 6, p.2, 2006a. 
KLEE, S. R. et al. Evaluation of a real-time PCR assay to detect Coxiella burnetii. Annals of the New York Academy of Science, v. 1078, p. 563-5, $2006 \mathrm{~b}$.

KLINGENBECK, L. et al. The Coxiella burnetii type IV secretion system substrate CaeB inhibits intrinsic apoptosis at the mitochondrial level. Cellular Microbiology,v. 15, p. 675687, 2013.

KOHLER, L. J. et al. Effector protein Cig2 decreases host tolerance of infection by directing constitutive fusion of autophagosomes with the Coxiella-containing vauole. mBio, v. 7, p. e01127-16, 2016.

LARSON, C. L. et al. Coxiella burnetii effector protein subverts clathrin-mediated vesicular trafficking for pathogen vacuole biogenesis. Proceedings of the National Academy of Sciences of the United States of America, v. 110, p. E4770-4779, 2013.

LARSON, C. L. et al. Right on Q: genetics begin to unravel Coxiella burnetii host cell interaction. Future Microbiology, v. 11, p. 919-39, 2016.

LATOMANSKI, E. A. et al. The effector Cig57 hijacks FCHO-mediated vesicular trafficking to facilitate intracellular replication of Coxiella burnetii. PLoS Pathogens, v. 12, p. e1006101, 2016.

LATZ, E.; XIAO, T. S.; STUTZ, A. Activation and regulation of the inflammasomes. Nature Reviews Immunology, v. 13, n. 6, p. 397-411, 2013.

LAVIN, Y. et al. Tissue-resident macrophage enhancer landscapes are shaped by the local microenvironment. Cell, v. 159, p. 1312-1326, 2014.

LAVIN, Y. et al. Regulation of macrophage development and function in peripheral tissues. Nature Reviews Immunology, v. 15, p. 731-44, 2015.

LEMAITRE, B. et al. The dorsoventral regulatory gene cassette spätzle/Toll/cactus controls the potent antifungal response in Drosophila adults. Cell, v. 86, n. 6, p. 973-83, 1996.

LOCATI, M.; MANTOVANI, A.; SICA, A. Macrophage activation and polarization as an adaptive component of innate imunity. Advances in Immunology, v. 120, p. 163-184, 2013.

LÜHRMANN, A. et al. Inhibition of pathogen-induced apoptosis by a Coxiella burnetii type IV effector protein. Proceedings of the National Academy of Sciences of the United States of America, v. 107, p. 18997-19001, 2010.

LÜHRMANN, A.; ROY, C. R. Coxiella burnetii inhibits activation of host cell apoptosis through a mechanism that involves preventing Cytochrome c release from mitochondria. Infection and Immunity, v. 75, p. 5282-5289, 2007.

MACKANESS, G. B. Cellular resistance to infection. Journal of Experimental Medicine, v. 116, p. 381-406, 1962. 
MANTOVANI, A. et al. Macrophage polarization: Tumor-associated macrophages as a paradigm for polarizes M2 mononuclear phagocytes. Trends in Immunology, v. 23, p. 549$555,2002$.

MANTOVANI, A. et al. The chemokine system in diverse forms of macrophage activation and polarization. Trends in Immunology, v. 35, p. 677-86, 2004.

MANTOVANI, A. et al. Macrophage plasticity and polarization in tissue repair and remodeling. The Journal of Pathology, v. 229, n. 2, p. 176-185, 2013.

MANTOVANI, A.; SICA, A.; LOCATI, M. Macrophage Polarization Comes of Age. Immunity, v. 23, n. 4, p. 344-6, 2005.

MARIM, F. M. et al. A method for generation of bone marrow-derived macrophages from cryopreservered mouse bone marrow cells. PLoS One, v. 5, n. 12, p. e15263, 2010.

MARTINEZ, F. O. et al. Transcriptional profiling of the human monocyte-to-macrophage differentiation and polarization: new molecules and patterns of gene expression.. Journal of Immunology, v. 177, p. 7303-7311, 2006.

MARTINEZ, F. O. et al. Macrophage activation and polarization. Frontiers in Bioscience: A Journal and Virtual Library, v. 13, p. 453-561, 2008.

MARTINEZ, F. O.; GORDON, S. The M1 and M2 paradigm of macrophage activation: time for reassessment. F1000Prime Reports, p. 6-13, eCollection, 2014.

MASCARENHAS, D. P. A. et al. Inhibition of caspase-1 or gasdermin-D enable caspase-8 activation in the Naip5/NLRC4/ASC inflammasome. PLoS Pathogens, v. 13, n. 8, p. e1006502, 2017.

McDONOUGH, J. A. et al. Host pathways importante for Coxiella burnetii infection revealed by genomewide RNA interference screening. mBio, v. 4, p. e00606e12, 2013.

McDONOUGH, J. A.; NEWTON, H. J.; ROY, C. R. Coxiella burnetii Secretion Systems. Advances in Experimental Biology and Medicine, v. 984, p. 170-197, 2012.

McLAUGHLIN, H. P. et al. Phylogenetic inference of Coxiella burnetii by 16S rRNA gene sequencing. PLoS ONE, v. 12, n. 12, p. e0189910, 2017.

MECONI, S. et al. Coxiella burnetii induces reorganization of the actin cytoskeletal in human monocytes. Infection and Immunity, v. 66, p. 5527-5533, 1998.

MEDZHITOV, R. Toll-like receptors and innate immunity. Nature Reviews Immunology, v. 1, p. 135-45, 2001.

MEDZHITOV, R.; JANEWAY, C. A. Jr. Innate Immunity: the virtues of a nonclonal system of recognition. Cell, v. 91, n. 3, p. 295-298, 1997.

MEDZHITOV, R.; JANEWAY, C. A. Jr. The Toll receptor family and microbial recognition. Trends in Microbiology, v. 8, n. 10, p. 452-456, 2000. 
MEDZHITOV, R.; PRESTON-HULBURT, P.; JANEWAY, C. A. Jr. A human homologue of the Drosophila Toll protein signals activation of adaptive immunity. Nature, v. 388, n. 6640, p. 394-7, 1997.

MEGHARI, S. et al. Deficient transendothelial migration of leukocytes in Q fever: the role played by interleukin-10. Journal of Infectious Diseases, v. 194, p. 365-369, 2006.

MEHRAJ, V. et al. Monocyte responses in the context of Q fever: from a static polarizes model to a kinetic model of activation. Journal of Infectious Diseases, v. 208, n. 6, p. 942 $51,2013$.

MERTENS, K.; SAMUEL, J. E. Defense mechanisms against oxidative stress in Coxiella burnetii: adaptation to na unique intracellular niche. Advances in Experimental Biology and Medicine, v. 984, p. 39-63, 2012.

MILLS, C. D. et al. M-1/M-2 macrophages and the Th1/Th2 paradigm. Journal of Immunology, v. 164, p. 6166-73, 2000.

MINNICK, M. F.; RAGHAVAN, R. Developmental Biology of Coxiella burnetii. Advances in Experimental Biology and Medicine, v. 984, p. 231-248, 2012.

MOFFATT, J.; NEWTON, P.; NEWTON, H. J. Coxiella burnetii: turning hostility into a home. Cellular Microbiology, v. 17, n. 5, p. 621-631, 2015.

MURRAY, P. J. Macrophage polarization. Annual Review of Physiology, v. 79, p. 541-566, 2017.

MURRAY, P. J. et al. Macrophage activation and polarization: Nomenclature and experimental guidelines. Immunity, v. 41, n. 1, p. 14-20, 2014.

NARASAKI, C. T.; TOMAN, R. Lipopolysaccharide of Coxiella burnetii. Advances in Experimental Biology and Medicine, v. 984, p. 64-90, 2012.

NATHAN, C. F. et al. Identification of interferon-gamma as the lymphokine that activates human macrophage oxidative metabolism and antimicrobial activity. Journal of Experimental Medicine, v. 158, p. 670-89, 1983.

NATHAN, C.; SHILOH, M. U. Reactive oxygen and nitrogen intermediates in the relationship between mammalian hosts and microbial pathogens. Procedings in National Academy of Sciences of the United States of America, v. 97, p. 8841-8848, 2000.

NEWTON, H. J. et al. A screen of Coxiella burnetii mutants reveals importante roles for Dot/Icm effectors and host autophagy in vacuole biogenesis. PLoS Pathogens, v. 10, p. e1004286, 2014.

NEWTON, H. J.; McDONOUGH, J. A.; ROY, C. R. Effector protein translocation by the Coxiella burnetii Dot/Icm type IV secretion system requires endocytic maturation of the pathogen-occupied vacuole. PLoS ONE, v. 8, p. e54566, 2013. 
O'NEILL, L. A.; GOLENBOCK, D.; BOWIE, A. G. The history of Toll-like receptors redefining innate immunity. Nature Reviews Immunology, v. 13, n. 6, p. 453-60, 2013.

OMSLAND, A. et al. Host cell-free growth of the Q fever bacterium Coxiella burnetii. Proceedings of the National Academy of Sciences of the United States of America, v. 106, p; 4430-4434, 2009.

OMSLAND, A. et al. Isolation from animal tissue and genetic transformation of Coxiella burnetii are facilitated by an improved axenix growth medium. Applied and Environmental Microbiology, v. 77, p. 3720-3725, 2011.

PACE, J. L. et al. Macrophage activation: priming activity from a $\mathrm{T}$ cell hybridoma is attributable to interferon-gamma. Proceedings of the National Academy of Sciences of the United States of America, v. 80, p. 3782-6, 1983.

PECHSTEIN, J.; SCHULZE-LUEHRMANN, J.; LÜHRMANN, A. Coxiella burnetii as a useful tool to investigate bacterial-friendly host cell compartments. International Journal of Medical Microbiology, v. 308, p. 77-83, 2018.

PERDIGUERO, E. G.; GEISSMAN, F. The development and maintenance of residente macrophages. Nature Immunology, v. 17, p. 2-8, 2015.

QIU, J.; LUO, Z.Q. Legionella and Coxiella effectors: strength in diversity and activity. Nature Reviews Microbiology, v. 15, n. 10, p. 591-605, 2017.

RAOULT, D. Host factors in the severity of Q fever. Annals of the New York Academy of Sciences, v. 590, p. 33-38, 1990.

ROCK, F. L. et al. A Family of human receptors structurally related to Drosophila Toll. Proceedings of the National Academy of Sciences of the United States of America, v. 95, n. 2, p. 588-93, 1998.

ROMANO, P. S. et al. The autophagic pathway is actively modulated by phase II Coxiella burnetii to efficiently replicate in the host cell. Cellular Microbiology, v. 9, p. 891-909, 2007.

ROUX, V. et al. Reassessment of the taxonomic position of Rickettsiella grylli. International Journal of Systematic Bacteriology, v. 47, p. 1255-1257, 1997.

SANDOZ, K. M. et al. Developmental transitions of Coxiella burnetii grown in axenic media. Journal of Microbiological Methods, v. 96, p. 104-110, 2014.

SATOH, T.; AKIRA, S. Toll-like receptor signaling and its inducible proteins. Microbiology Spectrum, v. 4, n. 6, p. MCHD-0040-2016, 2016.

SCOTT, C. C.; BOTELHO, R. J.; GRINSTEIN, S. Phagosome maturation: a few bugs in the system. Journal of Membrane Biology, v. 193, p. 137-152, 2003. 
SCOTT, G. H.; WILliAMS, J. C.; STEPHENSON, E. H. Animal models in Q fever: pathological responses of inbred mice to phase I Coxiella burnetii. Journal of General Microbiology, n. 133, p. 691-700, 1987.

SHANNON, J. G.; HEINZEN, R. A. Infection of human monocyte-derived macrophages with Coxiella burnetii. Methods in Molecular Biology, v. 431, p. 189-200, 2008.

SHANNON, J. G.; HOWE,, D.; HEINZEN, R. A. Virulent Coxiella burnetii does not activate human dendritic cells: role os lipopolysaccharide as a shielding molecule. Proceedings of the National Academy of Sciences of the United States of America, v. 102, p. 8722-8727, 2005.

SESHADRI, R. et al. Complete genome sequence of the Q-fever pathogen Coxiella burnetii. Proceedings of the National Academy of Sciences of the United States of America, v. 100, p. 5455-5460, 2003.

SOLTYSIAK, K. A.; VAN SCHAIK, E. J.; SAMUEL, J. E. Surfactant Protein D Binds to Coxiella burnetii and Results in a Decrease in Interactions with Murine Alveolar Macrophages. PLoS One, v.10, n. 9, p. e0136699, 2015.

STEIN, M. et al. Interleukin-4 potently enhances murine macrophage mannose receptor activity: a marker of alternative immunologic macrophage activation. Journal of Experimental Medicine, v. 176, p. 287-92, 1992.

TELEPNEV, M. V. et al. Tetraacylated lipopolysaccharide of Yersinia pestis can inhibit multiple Toll-like receptor mediated signaling pathways in human dendritic cells. Journal of Infected Diseases, v. 200, p. 1694-1702, 2009.

TING, J. P.; WILLINGHAM, S. B.; BERGSTRALH, D. T. NLRs at the intersection of cell death and immunity. Nature Reviews Immunology, v. 8, n. 5, p. 372-9, 2008.

TOMAN, R. et al. (Eds) Coxiella burnetii: Recent Advances and New Perspectives in Research of the Q Fever Bacterium. Advances in Experimental Medicine and Biology, v. 984, 2012.

TOMAN, R.; SKULTETY, L. Structural study on a lipopolysaccharide from Coxiella burnetii strain Nine Mile in avirulent phase II. Carbohydrates Research, v. 283, p. 175-185, 1996.

TOMAN, R.; SKULTETY, L.; IHNATKO, R. Coxiella burnetii glycomics and proteomics tools for linking structure o function. Annals of the New York Academy of Sciences, v. 1166, p. 67-78, 2009.

TUJULIN, E. et al. Effect of endocytosis inhibitors on Coxiella burnetii interaction with host cells. Acta Virologica, v. 42, p. 125-131, 1998.

TURCO, J.; THOMPSON, H. A.; WINKLER, H. H. Interferon-gamma inhibits growth of Coxiella burnetii in mouse fibroblastos. Infection and Immunity, v. 45, p. 781-783, 1984. 
VAN SCHAIK, E. et al. Molecular pathogenesis of the obligate intracellular bacterium Coxiella burnetii. Nature Reviews Microbiology, v. 11, p; 561-573, 2013.

VAN SCHAIK, E. J.; SAMUEL, J. E. Phylogenetic diversity, virulence and comparative genomics. Advances in Experimental Biology and Medicine, v. 984, p. 13-38, 2012.

VAZQUEZ, C. L.; COLOMBO, M. I. Coxiella burnetii modulates Beclin-1 and Bcl-2, preventing host cell apoptosis to generate a persistente bacterial infection. Cell Death and Differentiation, v. 17, n. 3, p. 421-438, 2010.

VISHWANATH, S.; HACKSTADT, T. Lipopolysaccharide phase variation determines the complement-mediated serum susceptibility of Coxiella burnetii. Infection and Immunity, v. 56, p. 40-44, 1988.

VOTH, D. E. et al. Coxiella burnetii inhibits apoptosis in human THP-1 cells and monkey primary alveolar macrophages. Infection and Immunity, v. 75, n. 9, p. 4263-4271, 2007.

VOTH, D. E.; HEINZEN, R. A. Lounging in a lysosome: the intracellular lifestyle of Coxiella burnetii. Cellular Microbiology, v. 9, p. 829-840, 2007.

VOTH, D. E.; HEINZEN, R. A. Sustained activation of Akt and Erk1/2 is required for Coxiella burnetii antiapoptotic activity. Infection and Immunity, v. 77, n. 1, p. 205-213, 2009.

VOTH, D. E.; HOWE, D.; HEINZEN, R. A. Coxiella burnetii inhibits apoptosis and modulates cell survival signaling in macrophages. FASEB Microbial Pathogenesis Meeting, $2007 \mathrm{a}$.

VOTH, D. E.; HOWE, D.; HEINZEN, R. A. Coxiella burnetii inhibits apoptosis in human THP-1 cells and monkey primary alveolar macrophages. Infection and Immunnity, v. 75, p. 4263-4271, 2007b.

WAAG, D.; THOMPSON, H. A. Pathogenesis of and immunity to Coxiella burnetii. In: Linder, L. E.; Lebeda, F. K.; Korch, G. W. (Eds). Biological weapons defense: infectious diseases and counter bioterrorism. Humana Press, Totowa, 2005.

WALLQVIST, A. et al. Mechanisms of action of Coxiella burnetii effectors inferred from host-pathogen protein interactions. PLoS One, v. 12, n. 11, p. e0188071, 2017.

WEBER, M. M.; FARIS, R. Subversion of the Endocytic and Secretory Pathways by Bacterial Effector Proteins. Frontiers in Cell and Developmental Biology, v. 6, p. 1, 2018.

WEISBURG, W. G. et al. Phylogenetic diversity of the Rickettsiae. Journal of Bacteriology, v. 171, p. 4202-4206, 1989.

WILLIAMS, J. C.; PEACOCK, M. G.; McCAUL, T. F. Immunological and biological characterization of Coxiella burnetii Phases I and II, separated from host components. Infection and Immunity, v. 32, p. 840-851, 1981. 
WYNN, T. A.; CHAWLA, A.; POLLARD, J. W. Macrophage biology in development, homeostasis and disease. Nature, v. 496, n. 7446, p. 445-455, 2013.

YANG, J. et al. Prevention of apoptosis by Bcl-2: release of cytochrome c from mitochondria blocked. Science, v. 275, p. 1129-1132, 1997.

YOSHIIE, K. et al. Induced production of nitric oxide and sensitivity of alveolar macrophages derived from mice with different sensitivity to Coxiella burnetii. Acta Virologica, v. 43, p. 273-278, 1999.

ZAMBONI, D. S. Genetic control of natural resistance of mouse macrophages to Coxiella burnetii infection in vitro: macrophages from restrictive strains control parasitophorous vacuole maturation. Infection and Immunity, v. 72, p. 2395-2399, 2004.

ZAMBONI, D. S. et al. Mouse resident peritoneal macrophages partially control in vitro infection with Coxiella burnetii phase II. Microbes and Infection, v. 4, p. 591-598, 2002.

ZAMBONI, D. S. et al. Coxiella burnetii express type IV secretion system protein that function similarly to components of the Legionella pneumophila Dot/Icm system. Mollecular Microbiology, v. 49, p. 965-976, 2003.

ZAMBONI, D. S. et al. Stimulation of toll-like receptor 2 by Coxiella burnetii is required for macrophage production of pro-inflamatory cytokines and resistance to infection. Journal of Biological Chemistry, v. 279, p. 54405-54415, 2004.

ZAMBONI, D. S.; RABINOVITCH, M. Nitric oxide partially controls Coxiella burnetii phase II infection in mouse primary macrophages. Infection and Immunity, v. 71, n. 3, p. 1225-33, 2003.

ZAMBONI, D. S.; RABINOVITCH, M. Phagocytosis of apoptotic cells increases the susceptibility of macrophages to infection with Coxiella burnetii phase II through downmodulation of nitric oxide production. Infection and Immunity, v. 75, p. 2075-2080, 2004.

ZAMBONI, D. S.; MORTARA, R. A.; RABINOVITCH, M. Infection of Vero cells with Coxiella burnetii phase II: relative intracellular bacterial load and distribution estimated by confocal laser scanning microscopy and morphometry. Journal of Microbiological Methods, v, 43, p. 22-232, 2001.

ZHANG, G. et al. Mechanisms of vaccine-induced protective immunity against Coxiella burnetii infection in BALB/c mice. Journal of Immunology, v. 179, p. 8372-8380, 2007.

ZHANG. G.; ZHANG, Y.; SAMUEL, J. E. Componentes of Protective Immunity. Advances in Experimental Biology and Medicine, v. 984, p. 91-104, 2012.

ZUSMAN, T. et al. The response regulator PmrA is a major regulator of the icm/dot type IV secretion system in Legionella pneumophila and Coxiella burnetii. Molecullar Microbiology, v. 63, p. 1508-1523, 2007. 


\section{ANEXO I - TRABALHO DE PRIMEIRA AUTORIA}

9.1. Anexo 1 - Artigo publicado (FERNANDES, Talita D et al. Infection and Immunity, 2016)

"Murine Alveolar Macrophages Are Highly Susceptible to Replication of Coxiella burnetii Phase II In Vitro"

- Publicado em: setembro de 2016 


\title{
Murine Alveolar Macrophages Are Highly Susceptible to Replication of Coxiella burnetii Phase II In Vitro
}

\author{
Talita D. Fernandes, ${ }^{a}$ Larissa D. Cunha, ${ }^{\text {a* }}$ Juliana M. Ribeiro, ${ }^{\text {a Liliana M. Massis, }},{ }^{a}$ Djalma S. Lima-Junior, ${ }^{\text {a }}$ (D) Hayley J. Newton, ${ }^{\text {b }}$ \\ (D) Dario S. Zamboni ${ }^{\mathrm{a}}$ \\ Department of Cell Biology, School of Medicine of Ribeirāo Preto, University of São Paulo, FMRP/USP, Ribeirăo Preto, São Paulo, Brazil ª; Department of Microbiology and \\ Immunology, University of Melbourne at the Peter Doherty Institute for Infection and Immunity, Melbourne, Victoria, Australia ${ }^{\text {b }}$
}

Coxiella burnetii is a Gram-negative bacterium that causes $Q$ fever in humans. $Q$ fever is an atypical pneumonia transmitted through inhalation of contaminated aerosols. In mammalian lungs, C. burnetii infects and replicates in several cell types, including alveolar macrophages (AMs). The innate immunity and signaling pathways operating during infection are still poorly understood, in part because of the lack of relevant host cell models for infection in vitro. In the study described here, we investigated and characterized the infection of primary murine AMs by C. burnetii phase II in vitro. Our data reveal that AMs show a pronounced M2 polarization and are highly permissive to C. burnetii multiplication in vitro. Murine AMs present an increased susceptibility to infection in comparison to primary bone marrow-derived macrophages. AMs support more than 2 logs of bacterial replication during 12 days of infection in culture, similar to highly susceptible host cells, such as Vero and THP-1 cells. As a proof of principle that AMs are useful for investigation of C. burnetii replication, we performed experiments with AMs from $\mathrm{Nos} 2^{-/-}$or Ifng ${ }^{-/-}$mice. In the absence of gamma interferon and nitric oxide synthase 2 (NOS2), AMs were significantly more permissive than wild-type cells. In contrast, $\mathrm{AMs}$ from $\mathrm{Il4}^{-/-}$mice were more restrictive to C. burnetii replication, supporting the importance of M2 polarization for the permissiveness of AMs to C. burnetii replication. Collectively, our data account for understanding the high susceptibility of alveolar macrophages to bacterial replication and support the use of AMs as a relevant model of C. burnetii growth in primary macrophages.

The intracellular bacterial pathogen Coxiella burnetii is the causative agent of the zoonotic infection termed Q fever. Human infection with C. burnetii can lead to asymptomatic seroconversion or symptomatic $Q$ fever, which often presents as an acute febrile illness. The nonspecific symptoms associated with acute infection indicate that it is likely significantly underdiagnosed. Acute infection is often self-limited, but in a minority of cases it can progress to a serious chronic infection that predominantly manifests as life-threatening endocarditis. Importantly, recent epidemiological data demonstrated the significant long-term health impact of $\mathrm{Q}$ fever, reporting that more than one in three patients continued to suffer from an impaired health status 24 months postdiagnosis (1).

Humans can become infected through the inhalation of contaminated aerosols, often from close contact with infected ruminants. Within the alveolar space, C. burnetii can infect a variety of cell types, including alveolar macrophages (AMs) (2). Essential to the capacity of $C$. burnetii to cause disease is the ability of the pathogen to replicate inside host cells within a unique lysosomederived vacuole. The infectious, or small-cell variant, form of the bacterium enters the host cell and is passively trafficked through the endocytic pathway before reaching the hydrolytic and acidic confines of the lysosome. These conditions trigger the metabolic activation of C. burnetii and stimulate the conversion to a largecell, replicative variant (3). This environment also triggers the active bacteria to assemble the Dot/Icm type IV secretion system that facilitates the translocation of over 130 effector proteins into the host cytoplasm (4). Collectively, the action of these effectors modulates the Coxiella-containing vacuole (CCV) to provide an environment conducive to replication (5). This intracellular life cycle holds true for both virulent (phase I) C. burnetii and avirulent (phase II) C. burnetii bacteria that have a lipopolysaccharide structure altered through genetic mutations that occur during serial passage in a nonimmunocompetent host (6).

It is clear that while development of the CCV is similar in many cell types, some cells, including primary peritoneal macrophages and bone marrow-derived macrophages (BMDMs), are intrinsically more restrictive to the intracellular replication of $C$. burnetii $(7,8)$. Furthermore, BMDMs from different inbred mouse strains vary in their ability to restrict C. burnetii infection, with $\mathrm{A} / \mathrm{J}$ and $\mathrm{BALB} / \mathrm{c}$ mice being more susceptible to C. burnetii phase II than many other mouse strains, including the C57BL/6 strain (9). The mechanisms through which different genetic backgrounds and cell types can control C. burnetii intracellular growth remain an area of interesting scientific pursuit.

AMs have long been considered the primary site of C. burnetii infection (2), and AMs from monkeys and humans have recently been used to explore the host-pathogen interactions that take place during C. burnetii infection. Cynomolgus monkey AMs were used to demonstrate the potent antiapoptotic activity asso-

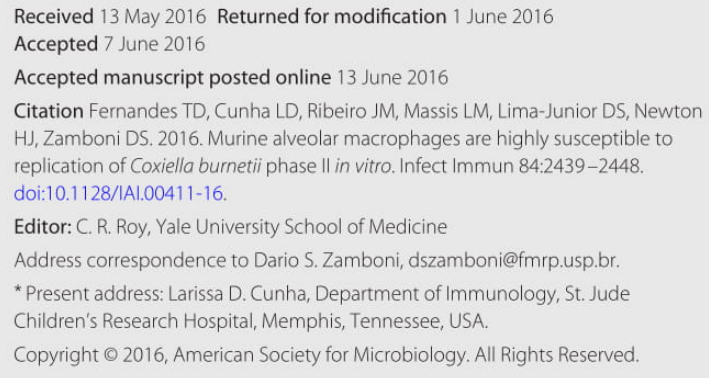


ciated with C. burnetii infection, although the replication dynamics of C. burnetii in this cellular model were not explored (10). More recently, human AMs, extracted from postmortem lung tissue samples, were shown to support the replication of different pathotypes of C. burnetii (11). In addition, this study demonstrated that both virulent (phase I) and avirulent (phase II) $C$. burnetii bacteria are able to infect human AMs. Interestingly, it was also observed that, within human AMs, C. burnetii more frequently forms multiple smaller CCVs rather than the large fusogenic vacuole observed in other cellular models of infection (11). Within a murine model of infection, it has been demonstrated that AMs are susceptible to C. burnetii infection (12), and an early study demonstrated that nitric oxide $(\mathrm{NO})$ is produced by murine $\mathrm{AMs}$ in response to infection (13).

In the study described here, we investigated and characterized the infection of primary murine AMs by C. burnetii phase II in vitro. Our data reveal that AMs are permissive to C. burnetii multiplication. The AMs showed a pronounced M2 polarization and showed an increased susceptibility to infection in comparison to murine BMDMs. Finally, we investigated the contribution of signaling molecules to the susceptibility of AMs to C. burnetii, demonstrating the utility of AMs for investigation of the host restriction of C. burnetii infection in relevant host cells.

\section{MATERIALS AND METHODS}

Preparation of C. burnetii for infection. Coxiella burnetii phase II Nine Mile strain (RSA439) bacteria were prepared from infected Vero cell monolayers as previously described (14). Confluent cultures of Vero cells were irradiated with $10 \mathrm{~Gy}{ }^{60} \mathrm{Co}$ to block cell division and maintained at $37^{\circ} \mathrm{C}$ in $5 \% \mathrm{CO}_{2}$ in Dulbecco modified Eagle medium (DMEM; Gibco) with $10 \%$ fetal bovine serum (FBS; Gibco) and $1 \mathrm{mM}$ L-glutamine (SigmaAldrich). Infection was carried out, and the cells were maintained under the above-described conditions for an additional 6 days. For the preparation of the Coxiella inoculum, infected Vero cells were lysed by homogenization in sterile distilled water. Cell lysates were clarified by centrifugation at $1,810 \times g$ for $10 \mathrm{~min}$ at $4^{\circ} \mathrm{C}$. The supernatant was extracted and centrifuged at $12,857 \times g$ for $30 \mathrm{~min}$ at $4^{\circ} \mathrm{C}$. The supernatant was discarded, and the pellet was resuspended in RPMI 1640 medium with $10 \%$ FBS. Bacterial aliquots were kept at $-80^{\circ} \mathrm{C}$. Prior to infection, aliquots were thawed at $37^{\circ} \mathrm{C}$ and subjected to sonication at $35 \mathrm{KHz}$ for $3 \mathrm{~min}$.

Mouse strains. A/J, C57BL/6, Nos $2^{-/-}, \mathrm{Ifng}^{-/-}$, and $I 4^{-/-}$mice (all in the C57BL/6 mouse genetic background) were bred in the Animal Facilities of the Medical School of Ribeirão Preto (FMRP/USP). All animals were provided food and water ad libitum, and the temperature was controlled at $25^{\circ} \mathrm{C}$. Mice were cared for according to the institutional guidelines on ethics in animal experiments (approved by the Comissão de Ética em Experimentação Animal da Faculdade de Medicina de Ribeirão Preto/ CETEA, protocol number 097/2010).

Culture of mammalian cell lines. THP-1 cells were cultured in RPMI 1640 medium (Sigma-Aldrich) with 10\% FBS, and Vero cells were maintained in DMEM (Gibco) with 10\% FBS (Gibco) and $1 \mathrm{mM} \mathrm{L-glutamine}$ (Sigma-Aldrich) at $37^{\circ} \mathrm{C}$ in $5 \% \mathrm{CO}_{2}$. For assays with THP-1 cells, differentiation into macrophage-like cells was mediated by the addition of 200 $\mathrm{nM}$ phorbol 12-myristate 13-acetate (PMA) to the culture overnight as described previously (10), and the medium was replaced with PMA-free medium prior to the infection. For infection of Vero cells, the cells were irradiated with $10 \mathrm{~Gy}{ }^{60} \mathrm{Co}$ and maintained overnight at $37^{\circ} \mathrm{C}$ in $5 \% \mathrm{CO}_{2}$ prior to the infection.

Bone marrow-derived macrophages. BMDMs were obtained and differentiated according to the protocol described previously (15). Briefly, bone marrow cells were harvested from femurs and differentiated with RPMI 1640 medium (Sigma-Aldrich) containing 20\% FBS (Invitrogen) and $30 \% \mathrm{~L}-929$ cell conditioned medium (LCCM) at $37^{\circ} \mathrm{C}$ in $5 \% \mathrm{CO}_{2}$
(15). Macrophages were harvested, counted, and seeded in 24-well plates at a density of $10^{5}$ cells/well 1 day prior to infection and kept in RPMI 1640 medium with $10 \%$ FBS and 5\% LCCM.

Alveolar macrophages. AMs were obtained from adult mice (age, 6 to 8 weeks) via bronchoalveolar lavage (BAL). The animals were euthanized, and the trachea was pierced with a sterile cannula (BD AngioCath). The lungs were washed four consecutive times with $1.0 \mathrm{ml}$ of warm sterile phosphate-buffered saline (PBS) containing $5 \mathrm{mM}$ EDTA, and the material was collected. Cells were transferred to a new sterile tube, washed twice in sterile PBS, and resuspended in RPMI 1640 medium with $10 \%$ FBS, $1 \mathrm{mM}$ L-glutamine, and $100 \mathrm{U} / \mathrm{ml}$ penicillin-streptomycin. Cells were seeded in 24-well plates at a density of $10^{5}$ cells/well. Macrophages were maintained in culture in RPMI 1640 medium with $10 \%$ FBS, $1 \mathrm{mM}$ L-glutamine, and $100 \mathrm{U} / \mathrm{ml}$ penicillin-streptomycin at $37^{\circ} \mathrm{C}$ in $5 \% \mathrm{CO}_{2}$. Culture medium was replaced two times before infection in antibioticfree medium. Fresh media were added to the macrophage cultures at day 6 postinfection.

C. burnetii infection of cells. Frozen stocks of $C$. burnetii were thawed at $37^{\circ} \mathrm{C}$ and treated in an ultrasound bath for $3 \mathrm{~min}$ to dissolve bacterial clumps. Tissue culture medium was aspirated from the cells and replaced with fresh medium before infection. Bacteria were homogenized with a pipette and applied directly to the cells at a multiplicity of infection (MOI) of 3 (except for the experiment whose results are presented in Fig. 1A, in which an MOI of 100 was used). The plates were centrifuged at $200 \times g$ for $5 \mathrm{~min}$ at $25^{\circ} \mathrm{C}$ and placed at $37^{\circ} \mathrm{C}$ in $5 \% \mathrm{CO}_{2}$. After $4 \mathrm{~h}$, the culture medium was aspirated, the wells were washed with warm sterile PBS, and fresh culture medium was added. As an internal experimental control of C. burnetii replication, infected cells were treated with $20 \mu \mathrm{g} / \mathrm{ml} \mathrm{rifampin}$ (RIF) to inhibit C. burnetii protein translation (16).

Fluorescence microscopy. AMs from C57BL/6 mice were seeded at a density of $10^{5}$ cells per well in a 24-well plate containing $13-\mathrm{mm}$ glass coverslips. Cells were infected with wild-type C. burnetii bacteria or $C$. burnetii bacteria expressing mCherry at an MOI of 3 as previously described (17). After 4 h, 3 days, 6 days, 9 days, or 12 days of infection, cells were fixed with $3.5 \%$ paraformaldehyde containing $7.5 \%$ sucrose for 20 min and then washed twice with room temperature PBS. For the assays with wild-type C. burnetii bacteria, the cells were then permeabilized for 2 min with ice-cold $100 \%$ methanol, followed by two more washes with PBS. Cellular autofluorescence was removed by incubation with $0.1 \mathrm{M}$ glycine in PBS for $10 \mathrm{~min}$, and then the samples were blocked for $30 \mathrm{~min}$ in PBS containing $1 \%$ bovine serum albumin (BSA; Sigma-Aldrich) and $5 \%$ goat serum at room temperature. The cells were incubated with rabbit anti-C. burnetii (1:100) and rat anti-LAMP-1 (1:2) primary antibodies diluted in $1 \%$ BSA in PBS for $1 \mathrm{~h}$, washed twice with room temperature PBS, and then incubated for $30 \mathrm{~min}$ in 1\% BSA in PBS containing Alexa Fluor 488- and Alexa Fluor 594-conjugated secondary antibodies (Invitrogen) at a concentration of 1:2,000. After three washes with room temperature PBS, cells were mounted with Prolong Gold antifade reagent containing DAPI (4', $6^{\prime}$-diamindino-2-phenylindole dilactate; Invitrogen). For the assays using mCherry-expressing C. burnetii, the cells were washed twice with room temperature PBS after the fixation and then directly mounted with Prolong Gold antifade reagent containing DAPI.

Multiphoton microscopy images were acquired using an LSM 780 Zeiss AxioObserver microscope equipped with a $63 \times$ oil immersion objective and analyzed using ImageJ software.

Transmission electron microscopy. AMs were infected for 3 or 6 days, washed once with PBS, fixed for $1 \mathrm{~h}$ at room temperature with modified Karnovsky's fixative ( $2 \%$ formaldehyde, $2.5 \%$ glutaraldehyde in $0.1 \mathrm{M}$ sodium cacodylate, $\mathrm{pH} 7.4$ ), dislodged by scraping, and then processed for and analyzed by transmission electron microscopy as previously described (7)

Quantification of C. burnetii. BMDMs, AMs, THP-1 cells, and irradiated Vero cells infected with C. burnetii were maintained in culture for up to 12 days. After 6 days of infection, cells were supplemented with an additional $500 \mu$ l of RPMI 1640 medium with $10 \%$ FBS and 5\% LCCM for 
BMDMs, RPMI 1640 medium with 10\% FBS for AMs and THP-1 cells, and DMEM (Gibco) with 10\% FBS (Gibco) and $1 \mathrm{mM} \mathrm{L-glutamine} \mathrm{(Sig-}$ ma-Aldrich) for irradiated Vero cells. At different times postinfection, cells were lysed with $1.0 \mathrm{ml}$ of deionized water and cell lysates were combined with the culture supernatant from the respective wells. The material was centrifuged at $14,000 \times g$ for $15 \mathrm{~min}$ at $4^{\circ} \mathrm{C}$ for deposition of the bacteria present in the samples. The DNA from C. burnetii was extracted using a Bacteria GenomicPrep Illustra kit (GE Healthcare), and the presence of genetic material was confirmed by spectrophotometry (determination of the absorbance at $260 \mathrm{~nm}$ ). The primer pair dotA-for and dotArev (18) was used for quantitative PCR ( $\mathrm{qPCR}$ ), a reliable method for quantification of bacterial replication, as demonstrated by Brennan and Samuel (16) for analyses involving C. burnetii. The reaction was performed using a Platinum SYBR green qPCR Supermix-UDG with carboxy-X-rhodamine (ROX) kit (Invitrogen), and thermocycling reactions were performed according to the manufacturer's instructions. The samples were read on an ABI Prism 7000 thermocycler.

RT-PCR analysis. mRNA from cultures of $10^{6}$ AMs and BMDMs derived from $\mathrm{C} 57 \mathrm{BL} / 6$ mice noninfected or infected for $12 \mathrm{~h}$ with $C$. burnetii at an MOI of 3 were extracted with the TRIzol reagent. RNA purification was done using an Illustra RNAspin minikit (GE Healthcare), according to the manufacturer's instructions, and genetic material was quantified using a NanoDrop spectrophotometer (Thermo Scientific). ImProm-II reverse transcriptase (Promega) was used to obtain cDNA. The real-time quantitative PCR assays were performed using the Platinum SYBR Green qPCR Supermix-UDG with carboxy-X-rhodamine kit (Invitrogen). Thermocycling reactions were performed according to the manufacturer's instructions, and the samples were read on a StepOnePlus real-time PCR system (Applied Biosystems). The expression of the target genes was calculated using the mean threshold cycle $\left(C_{T}\right)$ values of each sample, which were normalized to those for the housekeeping genes. The sequences of the primers used for reverse transcription-PCR (RT-PCR) are as follows: Gapdh-fwd, 5'-CATCACCATCTTCCAGGAGCG-3'; Gapdhrev, 5' -ACGGACACATTGGGGGTAGG-3'; Nos2-fwd, 5' -CGAAACGC TTCSCTTCCAA-3'; Nos2-rev, 5' -TGAGCCTATATTGCTGTGGCT-3'; Ifn-fwd, 5'-GCATCTTGGCTTTGCAGCT-3'; Ifn-rev, 5'-CCTTTTTGC CCTTGCTGTTG-3'; Tnf-fwd, 5' -TGTGCTCAGAGCTTTCAACAA-3'; Tnf-rev, 5'-CTTGATGGTGCATGAGA-3'; Tlr2-fwd, 5'-AAGTCTCC GGAATTATCAGTCC-3'; Tlr2-rev, 5'-TGATGGATGTCGCGGAT-3'; Il4-fwd, 5' -AAGAGCATCATGCAAATGGA-3'; Il4-rev, 5' -TTAAAGCA TGGTGGCTCAGTAC-3'; Arginase 1-fwd, 5'-GTTCCCAGATGTACCA GGATTC-3'; Arginase1-rev, 5'-CGATGTCTTTGGCAGATATGC-3'; Fizzl-fwd, 5' -TGTGGCTTTGCCTGTGGAT-3'; Fizzl-rev, 5'-TCTTAG GACAGTTGGCAGCAG-3'; Yml-fwd, 5' -GGGTTGGTTATGACAATG TCAG-3'; and Yml-rev, 5' -TGAAGTCATCCATGTCCAGG-3'.

Flow cytometry for phenotypic analysis. Single suspensions of AMs and BMDMs from C57BL/6 mice were stained with stains from the LIVE/ DEAD fixable blue dead cell stain kit (Invitrogen) in PBS to exclude dead cells. Cells were stained with fluorochrome-conjugated antibodies against surface markers CD11b (clone M1/70), F4/80 (clone BM8), CD206 (clone C068C2), and CD86 (clone GL-1), purchased from BD Biosciences (San Diego, CA), and dectin-1/CLEC7A (CD369), obtained from BioLegend, in PBS containing $1 \% \mathrm{FBS}$ for $30 \mathrm{~min}$ at $4^{\circ} \mathrm{C}$ and then washed. Staining was performed in the presence of $5 \mu \mathrm{g} / \mathrm{ml}$ of Fc Block (BD Biosciences). Cell acquisition was performed on a BD FACSCanto II flow cytometer using FACSDiva software (BD Biosciences). For each sample, at least 100,000 events were collected. Data were analyzed with FlowJo software (TreeStar).

Statistical analyses. Statistical analyses were performed using GraphPad Prism (version 5) software. The results were analyzed by a statistical test for analysis of variance (ANOVA) followed by the Bonferroni posttest or Student's $t$ test. Differences were considered statistically significant when the $P$ value was $<0.05$.

\section{RESULTS}

Alveolar macrophages from $\mathrm{C} 57 \mathrm{BL} / 6$ mice are permissive to replication of $C$. burnetii. We have previously shown that $\mathrm{BMDMs}$ from $\mathrm{A} / \mathrm{J}$ and $\mathrm{BALB} / \mathrm{c}$ are less restrictive to the replication of C. burnetii phase II than cells from mice with the C57BL/6 mouse genetic background. This was determined by assessing the formation of the large CCV and by the determination of the number of C. burnetii focus-forming units (9). To further confirm these data, we quantified the bacterial genomic DNA by quantitative PCR ( $\mathrm{PPCR}$ ) as a tool to assess the replication of C. burnetii in BMDMs as previously described (16). In agreement with previously published data (9), we found that BMDMs from C57BL/6 mice are highly restrictive to C. burnetii phase II, whereas BMDMs from A/J mice support some intracellular replication of C. burnetii phase II from days 3 to 12 postinfection. This was observed in experiments using high and low infection doses (MOIs, 100 and 3, respectively) (Fig. $1 \mathrm{~A}$ and $\mathrm{B}$, respectively). We continued the macrophage infection studies using an MOI of 3 . Because most of the gene-deficient mice generated thus far were constructed in the C57BL/6 mouse background, we aimed to identify a primary cell that supported the replication of C. burnetii phase II in culture. It is known that C. burnetii infects macrophages and monocytes, with AMs considered the primary target cell of infection $(10,12$, 19-22). Thus, we evaluated whether murine AMs from the C57BL/6 mouse strain support the replication of $C$. burnetii phase II in culture. Strikingly, when we assessed bacterial replication using $\mathrm{qPCR}$, we found that, as opposed to BMDMs, the AMs were highly permissive to C. burnetii phase II replication (Fig. 1C). Of note, the internalization of bacteria by these different cells was similar, as measured by determination of the number of C. burnetii genomes associated with the cells after $4 \mathrm{~h}$ of infection (Fig. $1 \mathrm{~A}$ to $\mathrm{D}$, insets). As a negative control for bacterial replication, rifampin treatment was included to kill the C. burnetii bacteria in the macrophages. Further, when we compared the C. burnetii replication in AMs from C57BL/6 and A/J mice, we found that AMs from both strains were equally permissive for $C$. burnetii replication (Fig. 1D). These data suggest that the genetic mechanisms controlling the natural resistance of BMDMs to C. burnetii may be less effective or absent in AMs. Importantly, AMs emerge as a very interesting model of the primary macrophage that supports the intracellular replication of C. burnetii phase II in culture. As such, we decided to further characterize C. burnetii replication in AMs.

Alveolar macrophages accumulate large amounts of intracellular bacteria within the Coxiella-containing vacuole. Given the robust replication of C. burnetii phase II in murine AMs (Fig. $1 \mathrm{C}$ and D), we aimed to assess bacterial replication in these macrophages by microscopy. AMs obtained from C57BL/6 mice were infected, and intracellular bacteria were visualized by immunofluorescence and transmission electron microscopy. Figure 2 illustrates the susceptibility of AMs over the first 6 days of C. burnetii phase II infection in culture. We detected an increased concentration of intracellular C. burnetii, stained in red, during the course of infection, suggesting that the bacteria can readily replicate in AMs. Further, the association of the bacteria with the lysosomal membrane marker LAMP-1 confirms that the bacteria replicate in the well-characterized lysosome-derived parasitophorous vacuole. During the procedures to stain the bacteria and LAMP-1, the AMs containing large spacious vacuoles were lost because these cells easily detach from the coverslips during the antibody washings. 

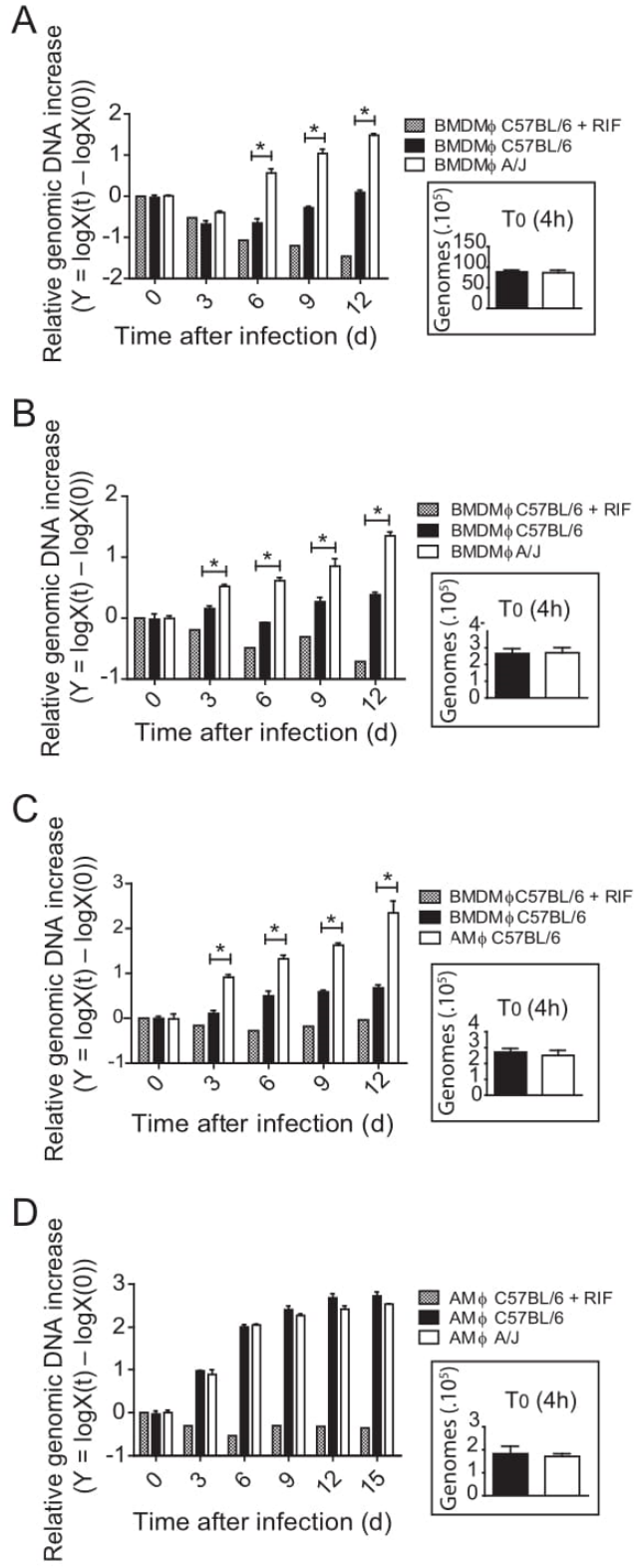

FIG 1 Alveolar macrophages are permissive to C. burnetii replication. BMDMs from C57BL/6 and A/J mice (A and B), BMDMs and AMs from C57BL/6 mice (C), or AMs from C57BL/6 and A/J mice (D) were infected with C. burnetii phase II (MOIs, $100[\mathrm{~A}]$ and 3 [B to D]), and bacterial multiplication was evaluated by quantification of the genomic DNA by qPCR after 0 (4h after infection), 3, 6, 9, 12 or 15 days (d) of infection. The $y$ axis represents the difference in the base 10 logarithm between the genomic quantity $X$ at time $t[\log X(t)]$ and the quantity $X$ at time zero $\left(T_{0}\right)[\log X(0)]$. Cells treated with RIF were used as a negative control of bacterial replication. (Insets) Amount of C. burnetii genomic DNA present in cells after $4 \mathrm{~h}$ of infection. The data shown are the means \pm standard errors of one representative experiment out of three performed. ${ }^{\star}, P<0.05$ (two-way ANOVA).
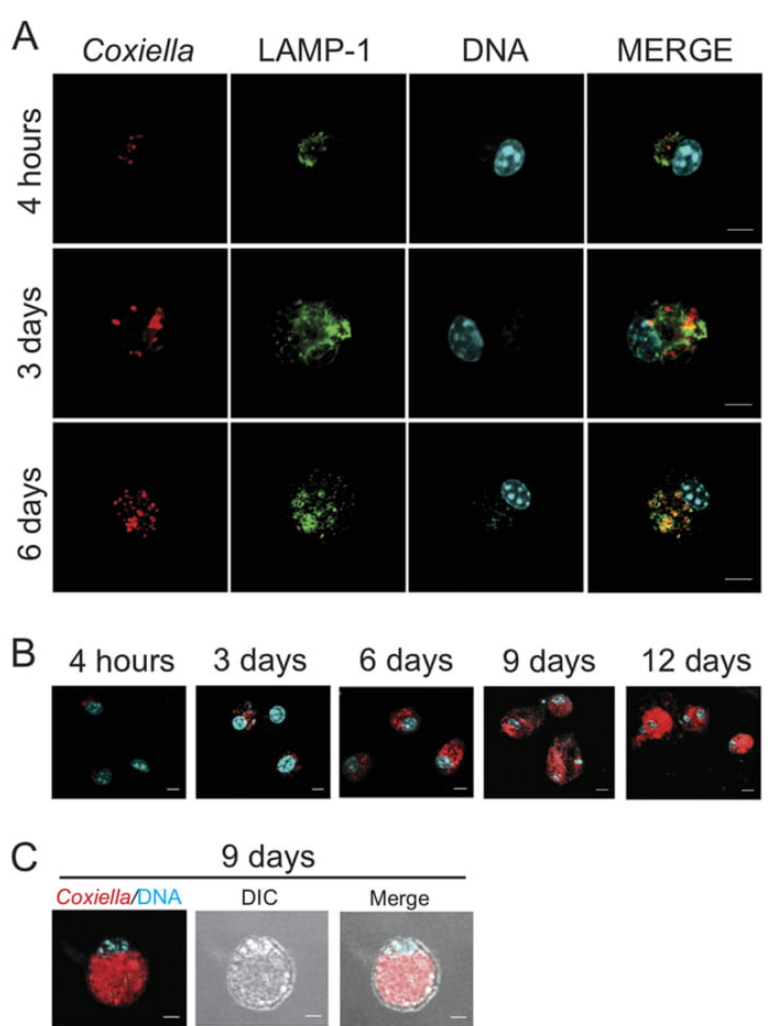

FIG 2 C. burnetii infection in alveolar macrophages assessed by fluorescence microscopy. AMs from C57BL/6 mice were infected with wild-type C. burnetii phase II (MOI, 3 ) for $4 \mathrm{~h}, 3$ days, and 6 days (A) or infected with mCherryexpressing C. burnetii phase II for 4 h, 3 days, 6 days, 9 days, and 12 days (B). After the indicated times, cells were fixed, processed, and then examined using multiphoton fluorescence microscopy. (C) AM infected for 9 days with mCherry-expressing C. burnetii. DIC, differential interference contrast. Green, lysosomal membrane-associated protein LAMP-1; red, C. burnetii; cyan, DAPI-stained DNA. Bars, $5 \mu \mathrm{m}$.

Thus, to assess the presence of typical large vacuoles in infected AMs, we used a strain of C. burnetii expressing mCherry (23). By examining the infected AMs using two-photon laser scanning fluorescence microscopy, we found a significant increase in bacterial replication in AMs from days 0 ( $4 \mathrm{~h}$ of infection) to 12 after infection (Fig. 2A and B). At day 6 of infection, we observed several cells containing many C. burnetii bacteria in large vacuoles (Fig. 2B). At day 9 of infection, the AMs were filled with C. burnetii bacteria, as illustrated by a merge image showing both differential interference contrast and fluorescence images (Fig. 2C). Intracellular bacteria were also observed by transmission electron microscopy (Fig. 3 ). At 3 days after infection, AMs showed large CCVs containing high numbers of large-cell variants of C. burnetii (Fig. 3A). At day 6 after infection, we detected vacuoles harboring a large amount of C. burnetii bacteria (Fig. 3B). Taken together, the results confirm that AMs support C. burnetii replication in culture and can be used as a useful model of the primary macrophage to study $C$. burnetii phase II replication in vitro.

Alveolar macrophages show a more pronounced polarization into M2 cells than bone marrow-derived macrophages. To 

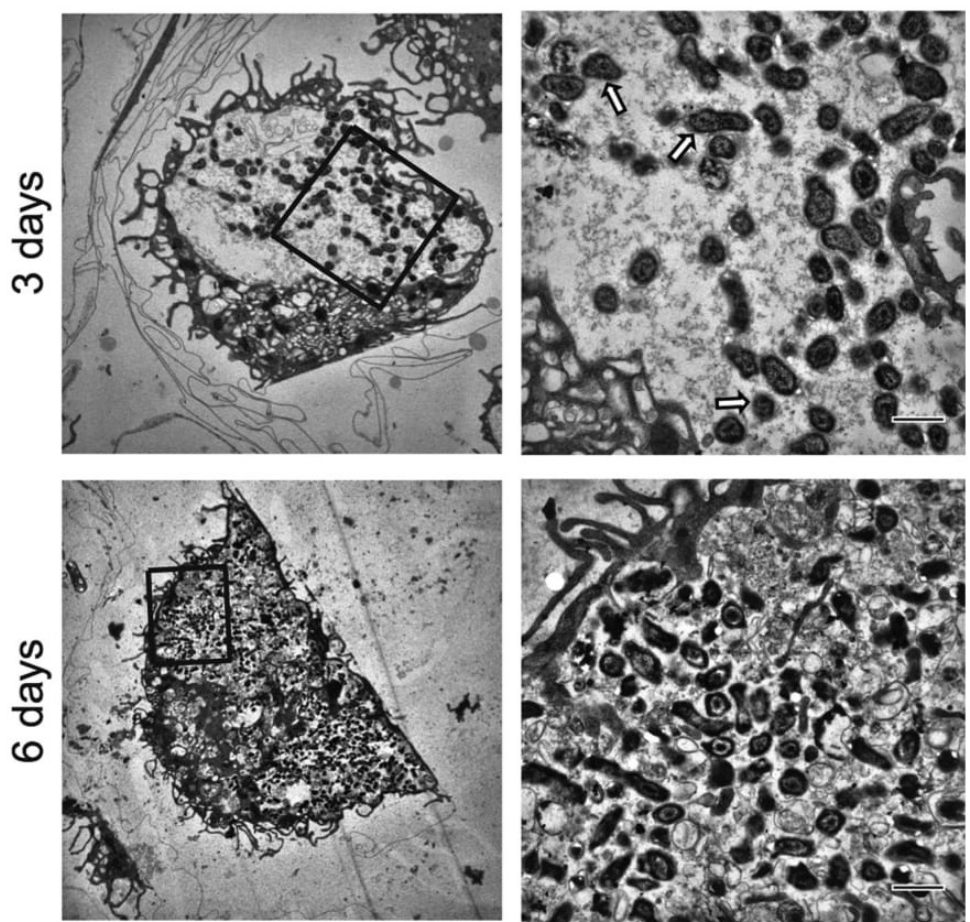

FIG 3 C. burnetii infection in alveolar macrophages assessed by transmission electron microscopy. AMs were infected with C. burnetii phase II (MOI, 3 ), fixed, and processed for transmission electron microscopy. Cells were fixed after 3 days (top) and 6 days (bottom) of infection. The panels on the right are enlarged images of the boxed regions in the panels on the left. Arrows, large-cell variant forms of C. burnetii. Bars, $1 \mu \mathrm{m}$.

assess the mechanisms underlying the permissiveness of AMs to $C$. burnetii, we evaluated M1/M2 polarization, which has previously been shown to be important for $C$. burnetii replication and pathogenesis $(24,25)$. Initially, we evaluated the expression of genes known to be hallmarks of M1 and M2 polarization in AMs and BMDMs. By measuring gene expression in noninfected BMDMs and AMs, we found that the latter show a significantly reduced expression of Nos2, Tnfa, Ifng, and Tlr2 (genes associated with an M1 polarization phenotype) and an increased expression of Arginase1, Fizz1, and Ym1, which are associated with an M2 profile (Fig. 4). The AMs also showed a pronounced M2 polarization compared to that of BMDMs in response to C. burnetii infection. We detected reduced expression of Nos2, Tnfa, Ifng, and Tlr2 and increased expression of Il4, Arginase1, Fizz1, and Ym1 in AMs infected with C. burnetii compared to their expression in infected BMDMs (Fig. 4). These data are consistent with AMs being more susceptible because they polarize toward an M2 phenotype. Accordingly, M1 macrophages effectively trigger the production of tumor necrosis factor alpha (TNF- $\alpha$ ), a cytokine known to facilitate the restriction of C. burnetii replication in macrophages (26). To further test this hypothesis, we evaluated the expression of surface markers known to be hallmarks of M2 macrophages, including mannose receptor (CD206) and dectin-1 (27). To evaluate protein expression, we performed fluorescence-activated cell sorting experiments in which we gated live macrophages and evaluated the expression of the cell surface markers CD206, dectin-1, and CD86 on cells double positive for CD11b and F4/80 (Fig. 5A and B). Using specific antibodies, we found that AMs showed increased expression of M2-associated molecules, such as CD206 (mannose receptor) and dectin-1 (CLEC7A), compared to BMDMs. This was evident under the uninfected condition (Fig. 5C) and in response to infection (Fig. 5D). Moreover, we measured the expression of the costimulatory molecule CD86, which was similarly expressed in AMs and BMDMs (Fig. 5C and D). These data are consistent with the hypothesis that AMs are more susceptible because of an M2 polarized phenotype, a characteristic that has previously been associated with permissiveness to C. burnetii replication (reviewed in reference 28).

Alveolar macrophages deficient in NOS2 and IFN- $\gamma$ are more susceptible to C. burnetii replication, whereas cells deficient in interleukin-4 (IL-4) are more restrictive to C. burnetii replication. It is well established that nitric oxide $(\mathrm{NO})$ is involved in the restriction of $C$. burnetii replication $(8,9,29,30)$. Thus, we assessed bacterial replication in AMs deficient in nitric oxide synthase 2 (NOS2; or inducible nitric oxide synthase [iNOS]) as a proof of principle that AMs can be used as a model to investigate the interactions of $C$. burnetii with primary mouse macrophages in the C57BL/6 mouse genetic background. In agreement with previous reports, we found that $\mathrm{AMs}$ from $\mathrm{Nos}^{-1-}$ mice are more permissive to $C$. burnetii phase II replication than AMs from wildtype C57BL/6 mice (Fig. 6A). We also evaluated bacterial replication in AMs from Ifng ${ }^{-/-}$mice because gamma interferon (IFN- $\gamma$ ) is known to be essential for NO production (31). Moreover, IFN- $\gamma$ is well described to be involved in the immune re- 

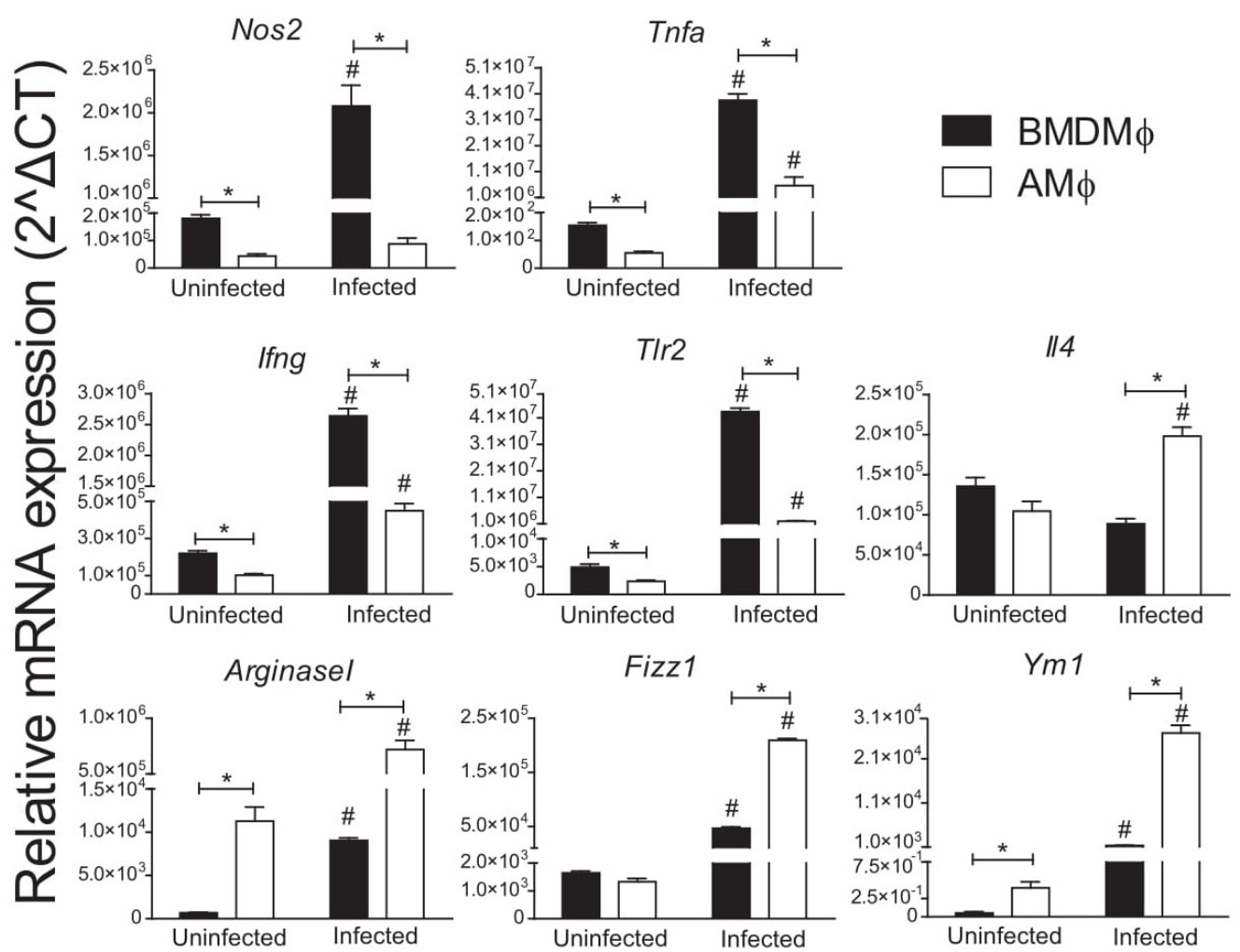

FIG 4 Alveolar macrophages exhibit higher levels of expression of genes related to the M2 phenotype. BMDMs and AMs from C57BL/6 mice were left uninfected or infected for $12 \mathrm{~h}$ with C. burnetii at an MOI of 3 . Total RNA was extracted, and reverse transcription-PCR (RT-PCR) was performed for detection of the genes Nos2, Tnfa, Ifng, Tlr2, Il4, Arginase 1, Fizz1, and Ym1. The data shown are the means \pm standard errors from one representative experiment out of two performed. ${ }^{*}, P<0.05$ comparing BMDMs and AMs; $\#, P<0.05$ comparing infected cells with the uninfected cells from the respective group (two-way ANOVA).

sponse against C. burnetii $(19,32-40)$. We found that AMs from Ifng ${ }^{-1-}$ mice are significantly more permissive to C. burnetii phase II replication than AMs from wild-type C57BL/6 mice (Fig. 6B). Collectively, these data support the use of AMs as a model of primary macrophages for investigations involving C. burnetii infections in primary macrophages from the C57BL/6 mouse, the strain mostly commonly used for the generation of transgenic mice. To further understand the effect of the M2 polarization of AMs that results in the increased susceptibility to C. burnetii, we performed experiments using AMs from mice deficient in IL-4, which is required for M2 differentiation (reviewed in reference 41). We found that AMs from $I l 4^{-1-}$ mice are less permissive to $C$. burnetii replication than cells from C57BL/6 mice (Fig. 6C). The internalization of bacteria did not differ in AMs from C57BL/6, Nos $2^{-1-}$, Ifng $g^{-1-}$, and $I l 4^{-1-}$ mice, as measured by the number of C. burnetii bacteria in cultures infected for $4 \mathrm{~h}$ (Fig. 6A to C, insets). Collectively, these data support the hypothesis that the M1/M2 polarization underlies the increased susceptibility of AMs in comparison to BMDMs. Importantly, regardless of the mechanisms associated with the resistance of the BMDMs, these data support the use of AMs as an important and relevant host cell for evaluation of C. burnetii replication in primary macrophages.

The permissiveness of mouse alveolar macrophages is comparable to that of highly susceptible immortalized cell lines. Our results demonstrated that murine AMs are permissive for C. burnetii phase II replication in vitro. Thus, we decided to compare $C$. burnetii phase II replication in C57BL/6 mouse AMs with that in highly susceptible host cells, such as Vero cells (a green monkey kidney cell line) and cells of a monocytic cell line (THP-1) differentiated into macrophage-like cells. Both of these cell types are known to be very susceptible to $C$. burnetii replication $(6,14,34)$. Figure 7 shows that at 6 days postinfection, murine AMs are as susceptible to C. burnetii phase II infection as Vero and THP-1 cells. At later time points after infection, the Vero and THP-1 cell lines supported bacterial replication more robust than that in primary AMs. Nonetheless, the comparable rate of replication during the first 6 days of infection reinforces the demonstration that murine AMs are indeed highly permissive for $C$. burnetii replication and can be used as a relevant host cell model for investigations involving the macrophage interaction with C. burnetii phase II in culture.

\section{DISCUSSION}

C. burnetii is a unique intracellular bacterial pathogen capable of replicating to high numbers within a lysosome-derived vacuole. Humans can contract Q fever through the inhalation of contaminated aerosols and the subsequent intracellular replication of $C$. burnetii within AMs. As such, studying the interaction between 
A Representative flow plots of BMDMs

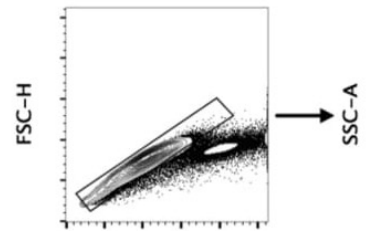

FSC-A

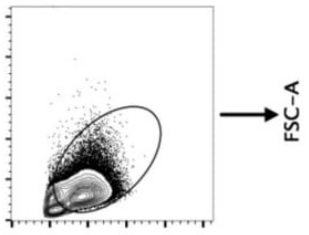

FSC-A

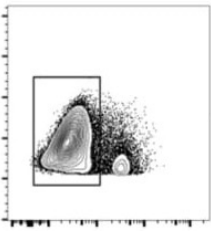

LIVE/DEAD

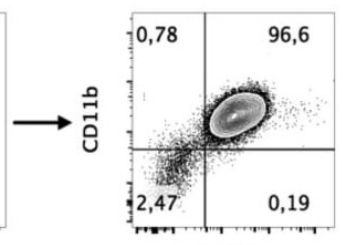

$\mathrm{F} 4 / 80$

B Representative flow plots of AMs
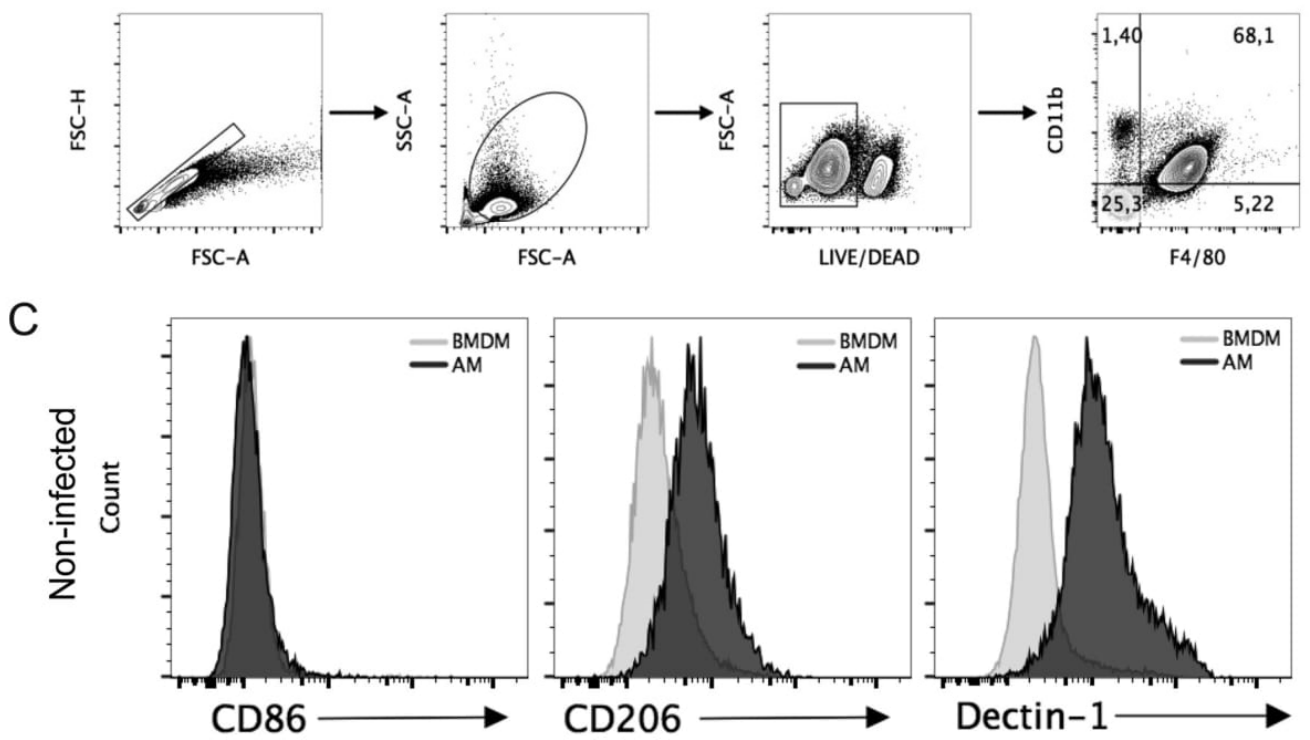

D
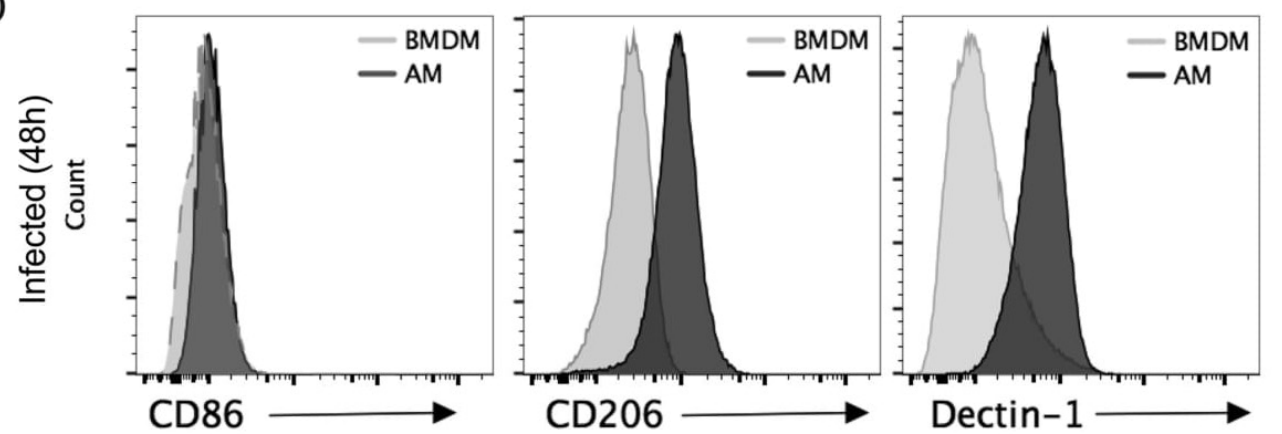

FIG 5 Alveolar macrophages exhibit an M2 phenotype. (A and B) Gating strategy and frequency of noninfected BMDMs (A) and AMs (B). FSC, forward scatter SSC, side scatter. (C and D) Surface phenotyping of BMDMs and AMs infected (for $24 \mathrm{~h}$ ) (C) or not infected (D) with C. burnetii for CD86 and the M2 markers CD206 and dectin-1, as analyzed by flow cytometry. Cells were gated on live CD11 b ${ }^{+}$F $/ 80^{+}$cells.

this specific macrophage lineage and the pathogen provides an important, disease-relevant, in vitro model to understand the specific host-pathogen interaction that takes place during C. burnetii infection. Previous research has demonstrated that BMDMs from different mouse strains vary in their permissiveness to C. burnetii replication (42). BMDMs from $\mathrm{A} / \mathrm{J}$ and $\mathrm{BALB} / \mathrm{c}$ mice support the intracellular replication of C. burnetii, while BMDMs from
C57BL/6 mice restrict bacterial replication. Here, we recapitulate these results and demonstrate that AMs are significantly more permissive to C. burnetii replication than BMDMs. This finding is most striking with C57BL/6 mice, in which BMDMs restrict the intracellular growth of C. burnetii, yet the bacteria readily replicate in AMs. Indeed, despite a remarkable difference in the replication of C. burnetii in BMDMs of C57BL/6 and $\mathrm{A} / \mathrm{J}$ mice, there is no 

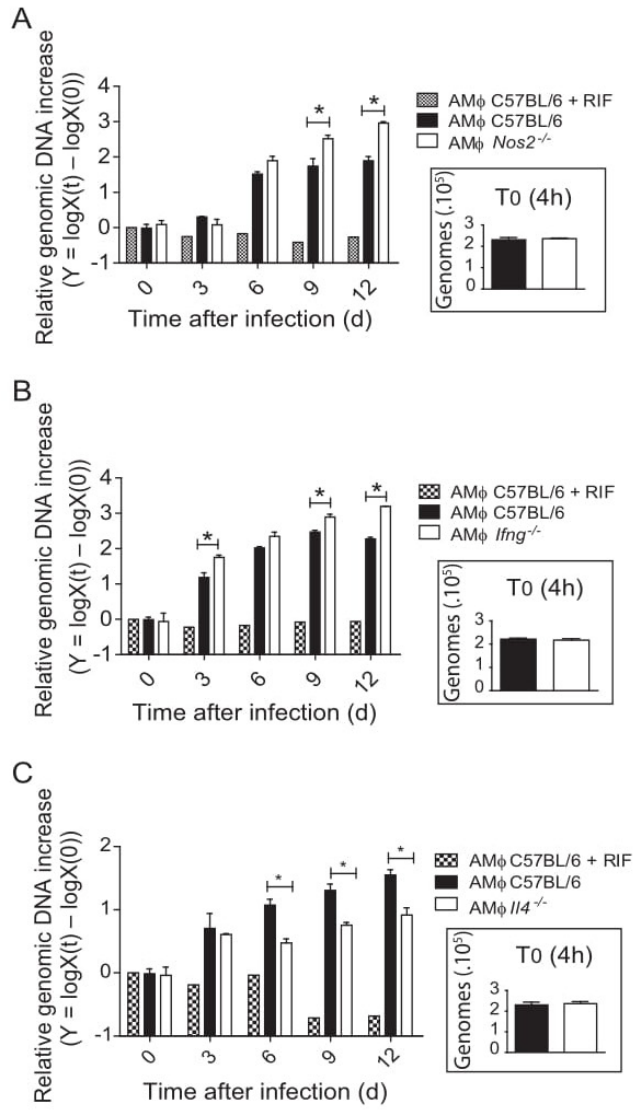

FIG 6 AMs support the assessment of innate immunity against C. burnetii phase II using knockout mice in the C57BL/6 mouse genetic background. Primary AMs from wild-type C57BL/6 mice and Nos2 ${ }^{-1-}$ (A), Ifng ${ }^{-1-}$ (B), and $I 4^{-1-}$ (C) mice were infected with C. burnetii phase II (MOI, 3), and bacterial multiplication was evaluated by quantification of the genomic DNA by $q$ PCR after 0 ( $4 \mathrm{~h}$ after infection), 3, 6, 9, and 12 days of infection. The $y$ axis represents the difference in the base 10 logarithm between the genomic quantity $X$ at time $t[\log X(t)]$ and the quantity $X$ at time zero $\left(T_{0}\right)[\log X(0)]$. Cells treated with RIF were used as a negative control of bacterial replication. (Insets) Amount of C. burnetii genomic DNA present in cells after $4 \mathrm{~h}$ of infection. The data shown are the means \pm standard errors from one representative experiment out of three independent experiments preformed. ${ }^{\star}, P<0.05$ (two-way ANOVA).

significant difference in the ability of $C$. burnetii to replicate in AMs from these two inbred mouse strains. This suggests that the genetic basis for C57BL/6 mouse BMDM restriction of C. burnetii infection reflects phenotypic features that may be specific for this cell type or that operate at a lower efficiency in AMs.

AMs are critical lung resident cells that, in healthy lungs, constitute the vast majority of the cellular content within alveoli (43). As such these cells are intricately essential for lung homeostasis and immune surveillance (44). Recent evidence indicates that AMs originate from fetal monocytes that are long living and are maintained by self-renewal rather than circulating bone marrowderived monocytes (45). This tissue microenvironment has a significant epigenetic and transcriptomic impact on resident macro-

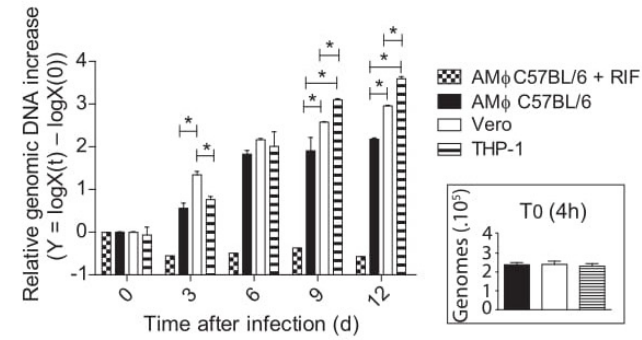

FIG 7 Alveolar macrophages are permissive to C. burnetii phase II replication, similar to Vero and THP-1 cells, in vitro. C57BL/6 AMs, irradiated Vero cells, and THP-1 cells (previously differentiated overnight with $200 \mathrm{nM}$ PMA) were infected with C. burnetii phase II (MOI, 3), and bacterial multiplication was evaluated by quantification of the genomic DNA by qPCR after 0 ( $4 \mathrm{~h}$ after infection), $3,6,9$, and 12 days of infection. The $y$ axis represents the difference in the base $10 \operatorname{logarithm}$ between the genomic quantity $X$ at time $t[\log X(t)]$ and the quantity $X$ at time zero $\left(T_{0}\right)[\log X(0)]$. Cells treated with RIF were used as a negative control of bacterial replication. (Insets) Amount of C. burnetii genomic DNA present in cells after $4 \mathrm{~h}$ of infection. The data shown are the means \pm standard deviations from one representative experiment out of three independent experiments preformed. ${ }^{*}, P<0.05$ (two-way ANOVA).

phages, rendering AMs phenotypically distinct from BMDMs (46-48). In light of our results, one can suggest that these phenotypic differences between BMDMs and AMs from C57BL/6 mice mediate a significant difference in the capacity to restrict the intracellular replication of $C$. burnetii. Interestingly, our data comparing M1/M2 polarization in BMDMs and AMs suggest that the M2 profile of AMs may underlie their increased susceptibility to infection. This hypothesis is supported by experiments using cells from $I l 4^{-1-}$ mice. In the absence of IL-4, the AMs became significantly more resistant to infection, a feature that is consistent with the essential role of IL-4 in the induction of M2 polarization (41). It is likely that during coevolution with mammalian hosts, C. burnetii has evolved strategies to target and subvert specific responses in alveolar macrophages, a process that may be facilitated by the anti-inflammatory M2 characteristics of this cell type.

In support of our data showing the increased replication of $C$. burnetii in AMs, it was previously reported that tissue-resident AMs are susceptible to C. burnetii replication in vivo (12). Moreover, human AMs were shown to support C. burnetii replication in culture (11). In addition, a system that allows infection of ex vivo human lung tissue was recently reported. It was found that within human lung tissue, $C$. burnetii preferentially replicated in human AMs (49). In this context, our data provide a definitive demonstration that mouse AMs can be used as a relevant host cell for investigations of the interactions of C. burnetii with host cells in vitro. C57BL/6 mouse AMs support the intracellular replication of C. burnetii, and the bacteria replicate in a manner that is comparable to that in widely used immortalized cell lines that are highly susceptible to C. burnetii replication. Over the first 6 days after infection, we found that $C$. burnetii phase II replicates similarly in AMs, THP-1 cells, and Vero cells. At days 9 and 12, we detected higher bacterial loads in Vero and THP-1 cells, which are possibly caused by the saturation of the host cells available for bacterial replication. This hypothesis is supported by the experiments performed with AMs infected with mCherry-expressing C. burnetii. After 9 days of infection, we visualized AMs filled with bacteria, which were contained in large vacuoles that occupy the entire 
macrophage cytoplasm (Fig. 2B and C). We did not detect a reduction of bacterial loads from days 9 to 12 , a feature that does not support the restriction of bacterial replication in the AMs at later stages of infection.

C57BL/6 mouse AMs can serve as an important host cell for the investigation of host factors that aid or restrict the intracellular replication of C. burnetii. Here we have confirmed the importance of both nitric oxide and IFN- $\gamma$ in restricting the ability of C. burnetii to replicate. Significantly higher levels of $C$. burnetii were recovered from both Nos $2^{-1-}$ and Ifng ${ }^{-1-}$ mouse AMs than from wild-type C57BL/6 mouse AMs. Production of nitric oxide and its reactive nitrogen intermediates is an important cellular response that acts against respiratory pathogens (50). At high levels, nitric oxide has a cytotoxic effect and can participate in the control of intracellular pathogen replication. Indeed, several studies have demonstrated that nitric oxide has the capacity to restrict the intracellular replication of C. burnetii $(8,9,29,30,51)$. Our data support these findings, demonstrating that AMs from C57BL/6 mice lacking Nos2 support higher levels of C. burnetii replication than wild-type cells. Similarly, the absence of IFN- $\gamma$, which is critical for nitric oxide production, is known to be important to host restriction of C. burnetii replication. Importantly, by using AMs from $\mathrm{Nos}^{-1-}$ and $\mathrm{Ifng}^{-1-}$ mice, we validated the use of AMs as a relevant host cell for the in vitro infection setting. Our characterization of this model of infection demonstrates that studying the interaction between C. burnetii and AMs will allow intricate investigation of both host and bacterial factors that are important for pathogenesis and host resistance during $\mathrm{Q}$ fever.

\section{ACKNOWLEDGMENTS}

We are grateful to Maira C. Nakamura and Victoria Maria dos Santos for technical assistance. We also thank Maria D. S. Ferreira, José A. Maulin, and Roberta R. Rosales for technical assistance in the institutional facilities for electron microscopy (M. D. S. Ferreira and J. A. Maulin) and multiphoton microscopy (R. R. Rosales).

We declare no conflict of interest in relation to this work.

This work was supported by grants from the Fundação de Amparo à Pesquisa do Estado de São Paulo (FAPESP; grants 2013/08216-2, 2014/ 50268-2, and 2014/04684-4), Conselho Nacional do Desenvolvimento Cientifico e Tecnológico (CNPq), Coordenação de Aperfeiçoamento de Pessoal de Nível Superior (CAPES), Fundação de Amparo ao Ensino, Pesquisa e Assistência do Hospital das Clínicas da FMRP/USP (FAEPA), and the Australian National Health and Medical Research Council (NHMRC; grants 1062383 and 1063646 to H.J.N.). T.D.F. and L.M.M. are supported by a fellowship from CAPES. L.D.C., J.M.R., and D.S.L. are supported by fellowships from FAPESP. H.J.N. is a visiting professor from the Science without Borders Program (CNPq; grant 401577/20147). D.S.Z. is a research fellow from CNPq, Brazil.

The funders had no role in study design, data collection and interpretation, or the decision to submit the work for publication.

\section{REFERENCES}

1. van Loenhout JA, Wielders CC, Morroy G, Cox MJ, van der Hoek W, Hautvast JL, Paget WJ, van der Velden J. 2015. Severely impaired health status of non-notified $Q$ fever patients leads to an underestimation of the true burden of disease. Epidemiol Infect 143:2580-2587. http://dx.doi.org 110.1017/S0950268814003689.

2. Khavkin T, Tabibzadeh SS. 1988. Histologic, immunofluorescence, and electron microscopic study of infectious process in mouse lung after intranasal challenge with Coxiella burnetii. Infect Immun 56:1792-1799.

3. Seshadri R, Hendrix LR, Samuel JE. 1999. Differential expression of translational elements by life cycle variants of Coxiella burnetii. Infect Immun 67:6026-6033.

4. Newton HJ, McDonough JA, Roy CR. 2013. Effector protein transloca- tion by the Coxiella burnetii Dot/Icm type IV secretion system requires endocytic maturation of the pathogen-occupied vacuole. PLoS One 8:e54566. http://dx.doi.org/10.1371/journal.pone. 0054566 .

5. Moffatt JH, Newton P, Newton HJ. 2015. Coxiella burnetii: turning hostility into a home. Cell Microbiol 17:621-631. http://dx.doi.org/10 $.1111 / \mathrm{cmi} .12432$.

6. Howe D, Shannon JG, Winfree S, Dorward DW, Heinzen RA. 2010. Coxiella burnetii phase I and II variants replicate with similar kinetics in degradative phagolysosome-like compartments of human macrophages. Infect Immun 78:3465-3474. http://dx.doi.org/10.1128/IAI.00406-10.

7. Zamboni DS, Mortara RA, Freymuller E, Rabinovitch M. 2002. Mouse resident peritoneal macrophages partially control in vitro infection with Coxiella burnetii phase II. Microbes Infect 4:591-598. http://dx.doi.org/10 1016/S1286-4579(02)01577-0.

8. Zamboni DS, Rabinovitch M. 2003. Nitric oxide partially controls Coxiella burnetii phase II infection in mouse primary macrophages. Infect Immun 71:1225-1233. http://dx.doi.org/10.1128/IAI.71.3.1225-1233 2003.

9. Zamboni DS, Rabinovitch M. 2004. Phagocytosis of apoptotic cells increases the susceptibility of macrophages to infection with Coxiella burnetii phase II through down-modulation of nitric oxide production. Infect Immun 72:2075-2080. http://dx.doi.org/10.1128/IAI.72.4.2075-2080 2004.

10. Voth DE, Howe D, Heinzen RA. 2007. Coxiella burnetii inhibits apop tosis in human THP-1 cells and monkey primary alveolar macrophages. Infect Immun 75:4263-4271. http://dx.doi.org/10.1128/IAI.00594-07.

11. Graham JG, MacDonald LJ, Hussain SK, Sharma UM, Kurten RC, Voth DE. 2013. Virulent Coxiella burnetii pathotypes productively infect primary human alveolar macrophages. Cell Microbiol 15:1012-1025. http: //dx.doi.org/10.1111/cmi.12096.

12. Calverley M, Erickson S, Read AJ, Harmsen AG. 2012. Resident alveolar macrophages are susceptible to and permissive of Coxiella burnetii infection. PLoS One 7:e51941. http://dx.doi.org/10.1371/journal pone.0051941

13. Yoshiie K, Matayoshi S, Fujimura T, Maeno N, Oda H. 1999. Induced production of nitric oxide and sensitivity of alveolar macrophages derived from mice with different sensitivity to Coxiella burnetii. Acta Virol 43:273-278.

14. Zamboni DS, Mortara RA, Rabinovitch M. 2001. Infection of Vero cells with Coxiella burnetii phase II: relative intracellular bacterial load and distribution estimated by confocal laser scanning microscopy and morphometry. J Microbiol Methods 43:223-232. http://dx.doi.org/10.1016 /S0167-7012(00)00223-2

15. Marim FM, Silveira TN, Lima DS, Jr, Zamboni DS. 2010. A method for generation of bone marrow-derived macrophages from cryopreserved mouse bone marrow cells. PLoS One 5:e15263. http://dx.doi.org/10.1371 /journal.pone.0015263.

16. Brennan RE, Samuel JE. 2003. Evaluation of Coxiella burnetii antibiotic susceptibilities by real-time PCR assay. J Clin Microbiol 41:1869-1874. http://dx.doi.org/10.1128/JCM.41.5.1869-1874.2003.

17. Cunha LD, Ribeiro JM, Fernandes TD, Massis LM, Khoo CA, Moffatt JH, Newton HJ, Roy CR, Zamboni DS. 2015. Inhibition of inflammasome activation by Coxiella burnetii type IV secretion system effector IcaA. Nat Commun 6:10205. http://dx.doi.org/10.1038/ncomms10205.

18. Carey KL, Newton HJ, Luhrmann A, Roy CR. 2011. The Coxiella burnetii Dot/Icm system delivers a unique repertoire of type IV effectors into host cells and is required for intracellular replication. PLoS Pathog 7:e1002056. http://dx.doi.org/10.1371/journal.ppat.1002056.

19. Amara AB, Bechah Y, Mege JL. 2012. Immune response and Coxiella burnetii invasion. Adv Exp Med Biol 984:287-298. http://dx.doi.org/10 1007/978-94-007-4315-1 15

20. Hackstadt T, Williams JC. 1981. Biochemical stratagem for obligate parasitism of eukaryotic cells by Coxiella burnetii. Proc Natl Acad Sci U S A 78:3240-3244. http://dx.doi.org/10.1073/pnas.78.5.3240.

21. Maurin M, Raoult D. 1999. Q fever. Clin Microbiol Rev 12:518-553.

22. Shannon JG, Heinzen RA. 2008. Infection of human monocyte-derived macrophages with Coxiella burnetii. Methods Mol Biol 431:189-200.

23. Beare PA, Gilk SD, Larson CL, Hill J, Stead CM, Omsland A, Cockrell DC, Howe D, Voth DE, Heinzen RA. 2011. Dot/Icm type IVB secretion system requirements for Coxiella burnetii growth in human macrophages. mBio 2:e00175-11. http://dx.doi.org/10.1128/mBio.00175-11.

24. Benoit M, Barbarat B, Bernard A, Olive D, Mege JL. 2008. Coxiella burnetii, the agent of Q fever, stimulates an atypical M2 activation pro- 
gram in human macrophages. Eur J Immunol 38:1065-1070. http://dx.do .org/10.1002/eji.200738067.

25. Mehraj V, Textoris J, Ben Amara A, Ghigo E, Raoult D, Capo C, Meg JL. 2013. Monocyte responses in the context of Q fever: from a static polarized model to a kinetic model of activation. J Infect Dis 208:942-951. http://dx.doi.org/10.1093/infdis/jit266.

26. Bradley WP, Boyer MA, Nguyen HT, Birdwell LD, Yu J, Ribeiro JM, Weiss SR, Zamboni DS, Roy CR, Shin S. 2016. Primary role for Toll-like receptor-driven tumor necrosis factor rather than cytosolic immune detection in restricting Coxiella burnetii phase II replication within mouse macrophages. Infect Immun 84:998-1015. http://dx.doi.org/10.1128/IAI .01536-15.

27. Martinez FO, Gordon S, Locati M, Mantovani A. 2006. Transcriptional profiling of the human monocyte-to-macrophage differentiation and polarization: new molecules and patterns of gene expression. J Immuno 177:7303-7311. http://dx.doi.org/10.4049/jimmunol.177.10.7303.

28. Benoit M, Desnues B, Mege JL. 2008. Macrophage polarization in bac terial infections. J Immunol 181:3733-3739. http://dx.doi.org/10.4049 /jimmunol.181.6.3733.

29. Brennan RE, Russell K, Zhang G, Samuel JE. 2004. Both inducible nitric oxide synthase and NADPH oxidase contribute to the control of virulent phase I Coxiella burnetii infections. Infect Immun 72:6666-6675. http: //dx.doi.org/10.1128/IAI.72.11.6666-6675.2004.

30. Howe D, Barrows LF, Lindstrom NM, Heinzen RA. 2002. Nitric oxide inhibits Coxiella burnetii replication and parasitophorous vacuole maturation. Infect Immun 70:5140-5147. http://dx.doi.org/10.1128/IAI.70.9 $.5140-5147.2002$.

31. Dinakar C, Malur A, Raychaudhuri B, Buhrow LT, Melton AL, Kavuru MS, Thomassen MJ. 1999. Differential regulation of human blood monocyte and alveolar macrophage inflammatory cytokine production by nitric oxide. Ann Allergy Asthma Immunol 82:217-222. http://dx.doi.org/10 1016/S1081-1206(10)62600-2.

32. Turco J, Thompson HA, Winkler HH. 1984. Interferon-gamma inhibits growth of Coxiella burnetii in mouse fibroblasts. Infect Immun 45:781-783.

33. Dellacasagrande J, Capo C, Raoult D, Mege JL. 1999. IFN-gammamediated control of Coxiella burnetii survival in monocytes: the role of cell apoptosis and TNF. J Immunol 162:2259-2265.

34. Ghigo E, Capo C, Tung CH, Raoult D, Gorvel JP, Mege JL. 2002. Coxiella burnetii survival in THP-1 monocytes involves the impairment of phagosome maturation: IFN-gamma mediates its restoration and bacterial killing. J Immunol 169:4488-4495. http://dx.doi.org/10.4049 /jimmunol.169.8.4488.

35. Andoh M, Zhang G, Russell-Lodrigue KE, Shive HR, Weeks BR, Samuel JE. 2007. T cells are essential for bacterial clearance, and gamma interferon, tumor necrosis factor alpha, and B cells are crucial for disease development in Coxiella burnetii infection in mice. Infect Immun 75:32453255. http://dx.doi.org/10.1128/IAI.01767-06.

36. Ochoa-Reparaz J, Sentissi J, Trunkle T, Riccardi C, Pascual DW. 2007. Attenuated Coxiella burnetii phase II causes a febrile response in gamma interferon knockout and Toll-like receptor 2 knockout mice and protects against reinfection. Infect Immun 75:5845-5858. http://dx.doi.org/10 .1128/LAI.00901-07.

37. Xiong X, Meng Y, Wang X, Qi Y, Li J, Duan C, Wen B. 2012. Mice immunized with bone marrow-derived dendritic cells stimulated with recombinant Coxiella burnetii Coml and Mip demonstrate enhanced bacterial clearance in association with a Th1 immune response. Vaccine 30. 6809-6815. http://dx.doi.org/10.1016/j.vaccine.2012.09.017.
38. Schoffelen T, Sprong T, Bleeker-Rovers CP, Wegdam-Blans MC, Ammerdorffer A, Pronk MJ, Soethoudt YE, van Kasteren ME, Herremans T, Bijlmer HA, Netea MG, van der Meer JW, Joosten LA, van Deuren M. 2014. A combination of interferon-gamma and interleukin-2 production by Coxiella burnetii-stimulated circulating cells discriminates between chronic $Q$ fever and past $Q$ fever. Clin Microbiol Infect 20:642-650. http://dx.doi.org/10.1111/1469-0691.12423.

39. Schoffelen T, Self JS, Fitzpatrick KA, Netea MG, van Deuren M, Joosten LA, Kersh GJ. 2015. Early cytokine and antibody responses against Coxiella burnetii in aerosol infection of BALB/c mice. Diagn Microbiol Infect Dis 81:234-239. http://dx.doi.org/10.1016/j.diagmicrobio.2014.12.008.

40. Schoffelen T, Wegdam-Blans MC, Ammerdorffer A, Pronk MJ, Soethoudt YE, Netea MG, van der Meer JW, Bleeker-Rovers CP, van Deuren M. 2015. Specific in vitro interferon-gamma and IL-2 production as biomarkers during treatment of chronic Q fever. Front Microbiol 6:93. http://dx.doi.org/10.3389/fmicb.2015.00093.

41. Gordon S. 2003. Alternative activation of macrophages. Nat Rev Immunol 3:23-35. http://dx.doi.org/10.1038/nri978.

42. Zamboni DS. 2004. Genetic control of natural resistance of mouse macrophages to Coxiella burnetii infection in vitro: macrophages from restrictive strains control parasitophorous vacuole maturation. Infect Immun 72:2395-2399. http://dx.doi.org/10.1128/IAI.72.4.2395-2399.2004.

43. Kopf M, Schneider C, Nobs SP. 2015. The development and function of lung-resident macrophages and dendritic cells. Nat Immunol 16:36-44. http://dx.doi.org/10.1038/ni.3052.

44. Morales-Nebreda L, Misharin AV, Perlman H, Budinger GR. 2015. The heterogeneity of lung macrophages in the susceptibility to disease. Eur Respir Rev 24:505-509. http://dx.doi.org/10.1183/16000617.0031-2015.

45. Guilliams M, De Kleer I, Henri S, Post S, Vanhoutte L, De Prijck S, Deswarte K, Malissen B, Hammad H, Lambrecht BN. 2013. Alveolar macrophages develop from fetal monocytes that differentiate into longlived cells in the first week of life via GM-CSF. J Exp Med 210:1977-1992. http://dx.doi.org/10.1084/jem.20131199.

46. Gosselin D, Link VM, Romanoski CE, Fonseca GJ, Eichenfield DZ, Spann NJ, Stender JD, Chun HB, Garner H, Geissmann F, Glass CK. 2014. Environment drives selection and function of enhancers controlling tissue-specific macrophage identities. Cell 159:1327-1340. http://dx.doi org/10.1016/j.cell.2014.11.023.

47. Lavin Y, Winter D, Blecher-Gonen R, David E, Keren-Shaul H, Merad M, Jung S, Amit I. 2014. Tissue-resident macrophage enhancer landscapes are shaped by the local microenvironment. Cell 159:1312-1326. http://dx.doi.org/10.1016/j.cell.2014.11.018.

48. Gordon S, Pluddemann A, Martinez Estrada F. 2014. Macrophage heterogeneity in tissues: phenotypic diversity and functions. Immunol Rev 262:36-55. http://dx.doi.org/10.1111/imr.12223.

49. Graham JG, Winchell CG, Kurten RC, Voth DE. 2016. Development of an ex vivo tissue platform to study the human lung response to Coxiella burnetii. Infect Immun 84:1438-1445. http://dx.doi.org/10.1128/IAI .00012-16.

50. Nathan C, Shiloh MU. 2000. Reactive oxygen and nitrogen intermediates in the relationship between mammalian hosts and microbial pathogens. Proc Natl Acad Sci U S A 97:8841-8848. http://dx.doi.org/10.1073/pnas 97.16 .8841 .

51. Hill J, Samuel JE. 2011. Coxiella burnetii acid phosphatase inhibits the release of reactive oxygen intermediates in polymorphonuclear leukocytes. Infect Immun 79:414-420. http://dx.doi.org/10.1128/LAI.01011-10. 
10. ANEXO II - TRABALHOS DE COLABORAÇÃO*

10.1. Anexo 2 - Artigo publicado (CUNHA, Larissa D; RIBEIRO, Juliana M; FERNANDES, Talita D; MASSIS, Liliana M; KHOO, Chen A; MOFFATT, Jennifer H; NEWTON, Hayley J; ROY, Craig R; ZAMBONI, Dario S. Nature Communications, 2015)

"Inhibition of inflammasome activation by Coxiella burnetii type IV secretion system effector IcaA"

- Publicado em: dezembro de 2015 


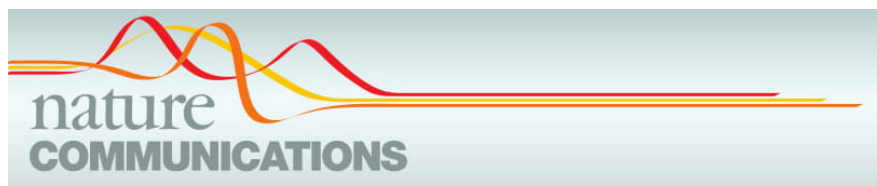

ARTICLE

Received 3 Sep 2015 | Accepted 13 Nov 2015 | Published 21 Dec $2015 \quad$ Dol: 10.1038/ncomms10205 OPEN

\title{
Inhibition of inflammasome activation by Coxiella burnetii type IV secretion system effector IcaA
}

\author{
Larissa D. Cunha ${ }^{1, \dagger}$, Juliana M. Ribeiro ${ }^{1}$, Talita D. Fernandes ${ }^{1}$, Liliana M. Massis ${ }^{1}$, Chen Ai Khoo ${ }^{2}$, \\ Jennifer H. Moffatt ${ }^{2}$, Hayley J. Newton ${ }^{2}$, Craig R. Roy ${ }^{3} \&$ Dario S. Zamboni ${ }^{1}$
}

Coxiella burnetii is a highly infectious bacterium that promotes its own replication in macrophages by inhibiting several host cell responses. Here, we show that $C$. burnetii inhibits caspase- 1 activation in primary mouse macrophages. By using co-infection experiments, we determine that the infection of macrophages with C. burnetii inhibits the caspase-11-mediated non-canonical activation of the NLRP3 inflammasome induced by subsequent infection with Escherichia coli or Legionella pneumophila. Genetic screening using flagellin mutants of L. pneumophila as a surrogate host, reveals a novel C. burnetii gene (IcaA) involved in the inhibition of caspase activation. Expression of IcaA in L. pneumophila inhibited the caspase-11 activation in macrophages. Moreover, ica $A^{-}$mutants of $C$. burnetii failed to suppress the caspase-11-mediated inflammasome activation induced by L. pneumophila. Our data reveal IcaA as a novel C. burnetii effector protein that is secreted by the Dot/Icm type IV secretion system and interferes with the caspase-11-induced, non-canonical activation of the inflammasome.

\footnotetext{
${ }^{1}$ Department of Cell Biology, Medical School of Ribeirão Preto, University of São Paulo (FMRP/USP), Ribeirão Preto, Sao Paulo 14049-900, Brazil.

${ }^{2}$ Department of Microbiology and Immunology, University of Melbourne at the Peter Doherty Institute for Infection and Immunity, Melbourne, Victoria 3000, Australia. ${ }^{3}$ Department of Microbial Pathogenesis, Yale University School of Medicine, New Haven, Connecticut 06536, USA. †Present address: Department of Immunology, St. Jude Children's Research Hospital, Memphis, Tennessee 38105, USA. Correspondence and requests for materials should be addressed to D.S.Z. (email: dszamboni@fmrp.usp.br).
} 
nnate immune cells have developed systems to signal and mount appropriate responses to pathogenic microbes by recognizing conserved molecules present in microbes (pathogen-associated molecular patterns, PAMPs) ${ }^{1}$. For intracellular pathogens, cytosolic nucleotide binding domain and leucine rich repeat containing proteins (NLR) play a pivotal role in recognizing and mounting effective immune responses. Caspase-1 activation mediated by NLR leads to interleukin-1 $\beta$ (IL-1 $\beta), \quad$ IL-18, IL-1 $\alpha$ release, membrane permeabilization and a specific form of inflammatory cell death called pyroptosis ${ }^{2}$. The activation of caspase- 1 by NLR occurs in a molecular platform known as an inflammasome ${ }^{3}$. Notably, the adaptor protein apoptosis-associated speck-like protein containing a carboxy-terminal CARD (ASC) is involved in the structure of different inflammasomes ${ }^{2}$. Several NLR, including NLRC4, NLRP1, NLRP3, NLRP6, NLRP12, neuronal apoptosis inhibitory protein 2 (NAIP2), NAIP5, NAIP6 and the cytosolic non-NLR receptor absent in melanoma 2 (AIM2), have been shown to activate the inflammasome in response to molecules derived from the different classes of pathogens. In particular, the specialized secretion systems of pathogenic Gram-negative bacteria have been shown to be a direct PAMP for inflammasome activation, and to be involved in processes that lead to delivery of specific PAMPs into the host cell cytoplasm ${ }^{4-8}$. In the case of the intracellular Gram-negative bacterium Legionella pneumophila, caspase-1 activation is readily triggered in response to the recognition of bacterial flagellin by NAIP5 and NLRC4, a process that requires the expression of a functional type IV secretion system (T4SS) called defect in organelle trafficking/ intracellular multiplication $(\mathrm{Dot} / \mathrm{Icm})^{9-11}$. Most recently, caspase-11 has emerged as an important regulator of inflammasome activation in response to the lipopolysaccharide (LPS) of Gram-negative bacterial species that either express a secretion system or escape to the host cell cytosol ${ }^{12-18}$. Caspase11 mediates NLRP3-dependent caspase-1 activation (called the non-canonical activation of the NLRP3 inflammasome), but also induces a caspase-1-independent membrane permeabilization that leads to pyroptosis and the release of inflammatory cytokines, including IL- $1 \alpha$.

Given the presence of a large repertoire of intracellular patternrecognition receptors mediating inflammasome activation and pyroptotic cell death, the bona fide intracellular pathogens have developed efficient strategies to manipulate host cell functions and subvert host surveillance (reviewed in Cunha et al. ${ }^{19}$ ). In this sense, the expression of specialized secretion systems that mediate the injection of pathogen effector proteins directly into host cell cytosol constitutes a widespread strategy used by intracellular bacterial pathogens to manipulate host cell functions ${ }^{20-22}$. For intracellular pathogens that target innate immune cells and are associated with severe and highly threatening chronic diseases, such as Chlamydia trachomatis, Coxiella burnetii and Mycobacterium tuberculosis, it is predictable that these pathogens encode unique defence mechanisms to subvert inflammasome activation. In fact, factors that inhibit inflammasome activation have been identified in $M$. tuberculosis and in C. trachomatis, although the molecular mechanisms of inflammasome inhibition and host cell targets are unclear ${ }^{23-25}$.

The intracellular bacterial pathogen $C$. burnetii is the causative agent of an acute pneumonia-like disease called Q fever, which may lead to endocarditis or hepatitis ${ }^{26}$. The bacteria replicate within a phagolysosomal vacuole and infect primarily alveolar macrophages (AMs) ${ }^{27}$. C. burnetii is highly specialized to subvert host cell functions, including the avoidance of TLRs recognition, the inhibition of apoptosis and the modulation of diverse vesicle traffic pathways ${ }^{28-39}$. However, immunocompetent individuals can effectively control bacterial multiplication, thus emphasizing that effective immune responses are critical for host resistance. C. burnetii is evolutionarily close to L. pneumophila, belonging to the order of Legionellales. Importantly, these pathogens share a homologous Dot/Icm type IV secretion system ${ }^{40}$. Historically, the genetic manipulation of $C$. burnetii has not been easily achieved, and as such, L. pneumophila has been used as a surrogate host to characterize and identify the C. burnetii Dot/Icm secretion system $^{41,42}$. C. burnetii encodes diverse putative effector proteins in its genome, some of them with sequence motifs predicted to mediate eukaryotic protein-protein interactions such as ankyrin repeat-containing and leucine-rich repetitioncontaining domains ${ }^{40,43}$. More than 100 putative $C$. burnetii effectors identified by genetic and bioinformatic whole-genome screens have been shown to be secreted by the Dot/Icm system of L. pneumophila ${ }^{44-50}$. Despite this massive identification of the C. burnetii effectors, the molecular function of very few effector proteins has been defined. Because $C$. burnetii is a highly virulent intracellular pathogen and very few cells ( $<5$ organisms) are sufficient to induce disease in a healthy human being, we investigated whether inflammasome activation occurs in response to $C$. burnetii infection. We found that $C$. burnetii inhibits the non-canonical activation of the NLRP3 inflammasome, which occurs in a process dependent on caspase-11 and independent of NLRC4 and bacterial flagellin. To search for the mechanism underlying the inhibition of the inflammasome by the bacterium, we screened potential effectors using L. pneumophila as a surrogate host and identified a C. burnetii effector protein, denoted herein as IcaA (Inhibition of caspase activation), that interferes with the caspase-11-mediated, non-canonical activation of the inflammasome. C. burnetii mutants for icaA fail to inhibit caspase-11 activation induced by flaA mutants of L. pneumophila. These findings unveil the process of inflammasome inhibition by $C$. burnetii and therefore contribute to our understanding of the molecular mechanisms underlying the virulence strategies used by this highly threatening obligate intracellular pathogen.

\section{Results}

C. burnetii infection does not stimulate inflammasome activation. To investigate whether $C$. burnetii induces caspase-1 activation, we infected murine bone marrow-derived macrophages (BMDMs) for $24 \mathrm{~h}$ and assessed the processing of caspase- 1 and pro-IL-1 $\beta$ by western blot. We found that the infection of wild-type C57BL/6 BMDMs (BL/6 BMDMs) with C. burnetii does not induce the cleavage of caspase-1 p20 subunit (Fig. 1a). As a control, we used L. pneumophila, which readily triggers the processing of these proteins in infected BMDMs (Fig. 1a). To further evaluate caspase-1 activation in response to C. burnetii, we assessed caspase-1 activation in BMDMs using the FAM-YVAD-FMK (FLICA), a previously described fluorescent probe that specifically binds the active form of caspase- 1 while inhibiting its autoproteolytic processing ${ }^{11}$. We found that in contrast to L. pneumophila infection, C. burnetii infection does not induce an increase in the percentage of cells stained with FLICA, as measured by flow cytometry (Fig. 1b,c). As a control, we used BMDMs from a Casp1/11 ${ }^{-}$mouse to indicate that this probe is specific to caspase-1. Finally, we measured the secretion of IL-1 $\beta$ as readout for caspase-1 activation. We found that as opposed to L. pneumophila infection, C. burnetii infection does not induce the secretion of IL-1 $\beta$ (Fig. 1a,d). Altogether, these data show that $C$. burnetii does not trigger caspase-1 activation in BMDMs.

C. burnetii inhibits NLRP3 activation induced by caspase-11. Although macrophages use multiple sensors to detect 


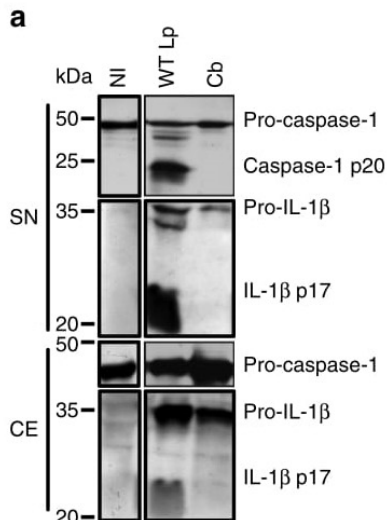

b

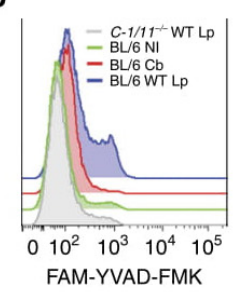

C

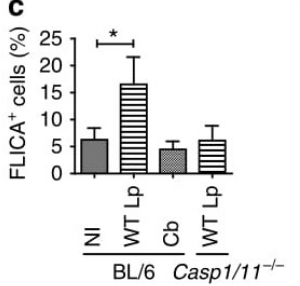

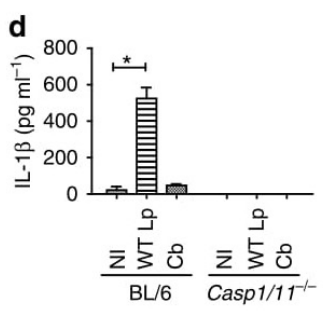

Figure 1 | Caspase-1 is not activated in macrophages infected with C. burnetii. Bone marrow-derived macrophages (BMDMs) remained noninfected (NI) or were infected with wild-type L. pneumophila for $9 \mathrm{~h}$ (WT Lp, multiplicity of infection (MOI) 10) or C. burnetii for $24 \mathrm{~h}(\mathrm{Cb}, \mathrm{MOI} 30$ ). (a) Immunoblot showing processed p20 subunit of caspase-1 (caspase-1 p20), unprocessed caspase-1 (pro-caspase-1), p17 subunit of mature IL-1 (IL-1 3 p17) and pro-IL$1 \beta$, as determined in the supernatant (SN) and in the cell extract (CE). (b) Flow analysis of FLICA staining in BL/6 BMDM noninfected (green curve), infected with $\mathrm{Cb}$ (red curve) or infected with WT Lp (blue curve) and Casp1/11 ${ }^{-/-}$BMDMs infected with WT Lp (grey curve). (c) Quantification of FLICApositive cells in (b). (d) IL-1 $\beta$ secretion in infected BMDMs was determined by ELISA. Data in (c,d) are expressed as average \pm s.e.m. of triplicate wells and significance was calculated with $t$-test. ${ }^{\star} P<0.05$ compared with $\mathrm{NI}$ cells. Data are representative of at least three independent experiments. Full blots are presented in the Supplementary Fig. 10.

Gram-negative bacteria, C. burnetii can evade immune responses and interfere with different cellular process to establish a replicative niche in these cells. Therefore, we investigated whether the absence of caspase- 1 activation results from the active process of inhibition by C. burnetii. Previous work has demonstrated that C. burnetii and L. pneumophila establish distinct and functional replicative vacuoles in co-infected $\mathrm{BMDMs}^{51}$. We thus performed co-infection studies to evaluate whether C. burnetii can actively inhibit the inflammasome activation triggered by L. pneumophila. We found that pre-infection of BMDMs with C. burnetii for $24 \mathrm{~h}$ resulted in reduced caspase- 1 activation and pro-IL-1 $\beta$ cleavage in response to a second infection with L. pneumophila (Fig. 2a). Notably, pre-infection with $C$. burnetii induced a significantly higher expression of pro-casp-1 and pro-IL-1 $\beta$, than single infections with $L$. pneumophila, possibly because of the presence of C. burnetii PAMPs during the 24-h pre-stimulation. To guarantee that the cells were stimulated similarly during the co-infection experiments, we pre-infected BMDMs with live or paraformaldehyde (PFA)-fixed C. burnetii before infections with L. pneumophila. We found that PFA-inactivated C. burnetii induced a similar expression of pro-casp-1 as the live bacteria, but only live $C$. burnetii inhibited caspase-1 activation in response to L. pneumophila (Supplementary Fig. 1a). These data indicate that the inhibition of caspase-1 activation is an actively induced process that requires $C$. burnetii metabolic activity. Caspase-1 activation in response to L. pneumophila occurs via at least two distinct pathways, one dependent on and another independent of bacterial flagellin ${ }^{52}$. To evaluate whether C. burnetii inhibits the flagellin-dependent or -independent pathway triggered by L. pneumophila infection, we performed co-infections of C. burnetii with wild-type (WT Lp) or flagellin-deficient $\left(\right.$ flaA $\left.^{-}\right)$L. pneumophila. We found that C. burnetii pre-infection inhibits caspase- 1 activation and IL-1 $\beta$ processing in response to either WT Lp or flaA- L. pneumophila (Fig. 2a). Strikingly, the co-infections performed with $\mathrm{flaA}^{-}$ L. pneumophila revealed that the flagellin-independent pathway for caspase-1 activation was abolished when the BMDMs were pre-infected with C. burnetii (Fig. 2a). These data indicate that C. burnetii effectively inhibits the flagellin-independent pathway for caspase-1 activation. Similar experiments performed with PFA-fixed C. burnetii indicated that live C. burnetii is required for the inhibition of caspase-1 activation in response to $\mathrm{flaA}^{-}$ L. pneumophila (Supplementary Fig. 1b).

These findings were further confirmed by the assessment of endogenous caspase-1 activation with the FLICA assay. BMDMs pre-infected with $C$. burnetii showed a reduction in caspase-1 activation in response to infection with both the WT Lp and fla $^{-}$L. pneumophila (Fig. 2b-d). As demonstrated by western blot, when co-infections were performed using $\mathrm{flaA}^{-}$ L. pneumophila, we found that BMDMs do not trigger caspase-1 activation (Fig. 2c,d). Pre-infections with C. burnetii did not reduce the internalization of $L$. pneumophila in BMDMs (Supplementary Fig. 2), confirming that this phenomenon is not caused by differences in L. pneumophila internalization after a previous exposure to $C$. burnetii. The C. burnetii-mediated inhibition of caspase-1 activation induced by $L$. pneumophila was also assessed by measuring the secretion of active IL-1 $\beta$ by enzyme-linked immunosorbent assay (ELISA). We found that pre-infection with live $C$. burnetii inhibited the secretion of IL-1 $\beta$ in response to infection with WT Lp, and abolished the secretion of IL-1 $\beta$ in response to infection with flaA $^{-}$L. pneumophila (Fig. 2e).

We investigated whether $C$. burnetii is able to inhibit caspase-1 activation in response to other stimuli. Thus, BMDMs pre-infected or not with $C$. burnetii were stimulated with LPS + ATP or with LPS + dsDNA to trigger the activation of the inflammasomes dependent on NLRP3 and AIM2, respectively. We found that $C$. burnetii fails to inhibit caspase-1 activation in response to ATP (Supplementary Fig. 3a,c) and dsDNA (Supplementary Fig. 3b,d). These results argue that C. burnetii does not directly inhibit caspase-1 activation but may interfere with upstream events in the signalling cascade of the inflammasome 

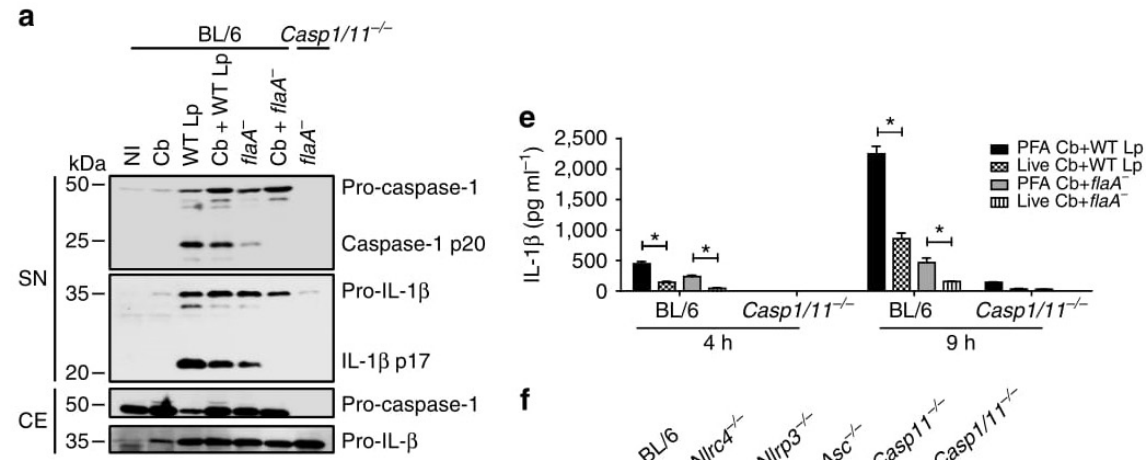

b

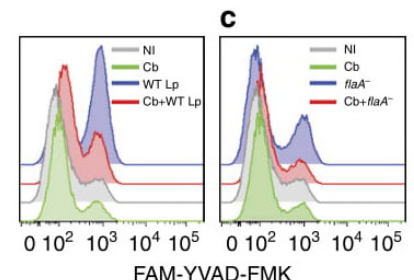

d

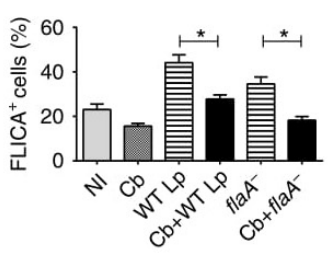

$f$

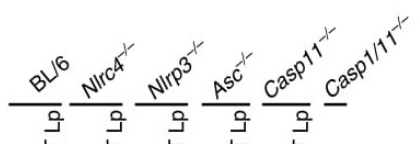

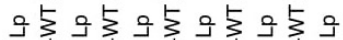
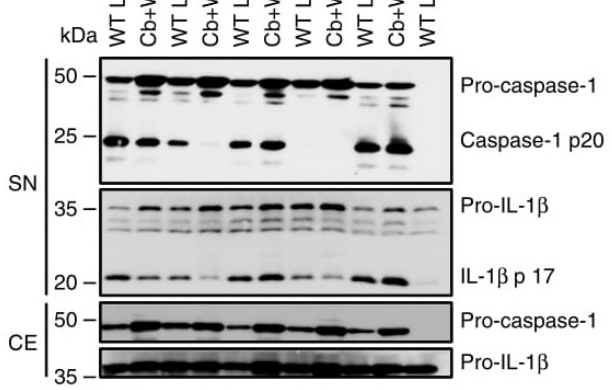

Figure 2 | C. burnetii inhibits the caspase-11-mediated non-canonical activation of the NLRP3 inflammasome induced by $L$. pneumophila. Bone marrowderived macrophages (BMDMs) were left noninfected $(\mathrm{NI})$ or were infected with $\mathrm{C}$. burnetii $(\mathrm{Cb}, \mathrm{MOI} 30)$ for $24 \mathrm{~h}$ and further infected with wild-type L. pneumophila (WT Lp, MOI 10) or flaA- $(\mathrm{MOI} 10)$ for $9 \mathrm{~h}$. Co-infected BMDMs are indicated (Cb $+\mathrm{WT} \mathrm{Lp}_{\text {or }} \mathrm{Cb}+\mathrm{flaA}^{-}$). (a) Immunoblot showing levels of processed p20 subunit of caspase-1 (caspase-1 p20), unprocessed caspase-1 (pro-caspase-1), p17 subunit of mature IL-1 (IL-1 $\beta$ p17) and pro-IL$1 \beta$, as determined in supernatant (SN) and cell extract (CE). (b,c) Flow analysis of FLICA staining in BL/6 BMDM noninfected (grey curve), infected with $\mathrm{Cb}$ (green curve), infected with L. pneumophila (blue curve) or co-infected (red curve). (d) Quantification of FLICA-positive cells in (b,c). (e) IL-1 $\beta$ secretion in infected BMDMs was determined by ELISA. BMDMs infected with live $C$. burnetii (live $\mathrm{Cb}$ ) or with PFA-fixed were used. (f) Caspase-1 cleavage and IL-1 $\beta$ secretion were evaluated by immunoblot as in (a). Data in $(\mathbf{d}, \mathbf{e})$ are expressed as average \pm s.e.m. of triplicate wells and significance was calculated with ANOVA. ${ }^{\star} P<0.05$. Data are representative of three $(\mathbf{a}, \mathbf{f})$ and two $(\mathbf{b}-\mathbf{e})$ independent experiments.

triggered by $L$. pneumophila. It was recently demonstrated that $L$. pneumophila triggers the non-canonical activation of the NLRP3 inflammasome in a process independent of flagellin and dependent on caspase-11 (ref. 13). Thus, we used BMDMs from Nlrc4 ${ }^{-1-}$, Nlrp3 $3^{-/-}, A s c^{-/-}$or Casp $11^{-/-}$mice to evaluate the requirement of these proteins for the C. burnetii-mediated inhibition of caspase-1 activation in response to L. pneumophila. We found that the inhibition of caspase-1 processing occurs in Nlrc4 $4^{-1-}$ BMDMs, a feature that is consistent with the findings that $C$. burnetii inhibits the flagellin-independent pathway for caspase-1 activation (Fig. 2f). In the absence of ASC, we detected no caspase-1 processing. In Nlrp $3^{-/-}$and Casp $11^{-/-}$BMDMs, we found that $C$. burnetii fails to inhibit caspase-1 cleavage and the processing of pro-IL-1 $\beta$ (Fig. $2 \mathrm{f}$ ). This feature is consistent with the hypothesis that $C$. burnetii inhibits the non-canonical activation of the NLRP3 inflammasome, which occurs through caspase-11 and culminates in the activation of the NLRP3/ASC/caspase-1 platform, leading to caspase- 1 cleavage and $\mathrm{IL}-1 \beta$ production ${ }^{53}$. It was previously demonstrated that Gram-negative bacteria, such as $E$. coli, or the combination of LPS plus the B subunit of cholera toxin
(CTB) triggers the non-canonical activation of the inflammasome ${ }^{18,53}$. Thus, to test whether C. burnetii inhibits the non-canonical activation of the inflammasome, we pre-infected BMDMs with C. burnetii, stimulated with either LPS + CTB or E. coli and measured caspase-1 activation. We found that C. burnetii pre-infection severely inhibited caspase- 1 activation and pro-IL-1 $\beta$ processing in response to $E$. coli (Fig. 3a). According to previous reports, the $E$. coli-induced activation of caspase-1 and pro-IL-1 $\beta$ cleavage was dependent on NLRP3 and ASC (Fig. 3a). Supporting the inhibitory activity of $C$. burnetii in the non-canonical inflammasome activation, we found that the release of IL-1 $\beta$ and IL- $1 \alpha$ in response to E. coli or LPS + CTB is reduced in BMDMs pre-infected with C. burnetii (Fig. 3b-e). Next, we used a pore formation assay that reflects a caspase-11 activity that operates independently of NLRC4 inflammasome and upstream of the noncanonical activation of the NLRP3 inflammasome ${ }^{13,54}$. By coinfecting cells with C. burnetii and E. coli, we found that C. burnetii is able to inhibit the caspase-11-mediated pore formation induced by $E$. coli (Fig. 3f-h). In this experiment, we also included BMDMs from a mouse deficient in caspase-1. This mouse, herein called 
a

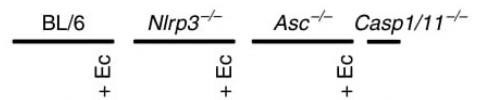

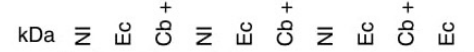

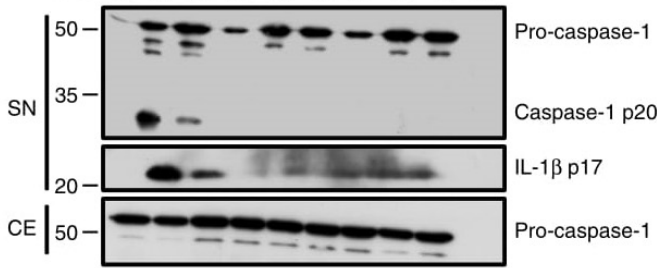

b
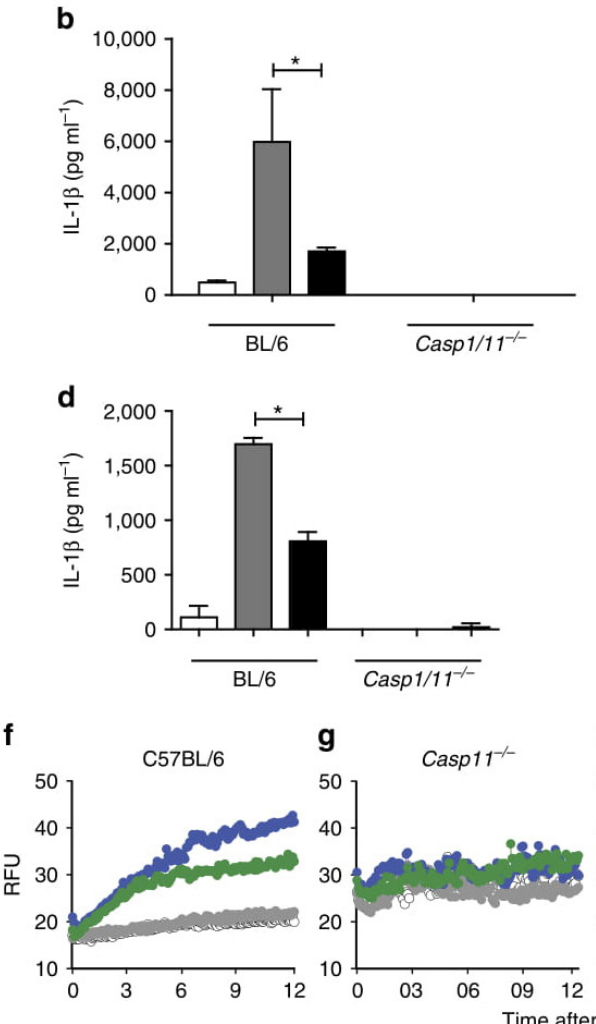
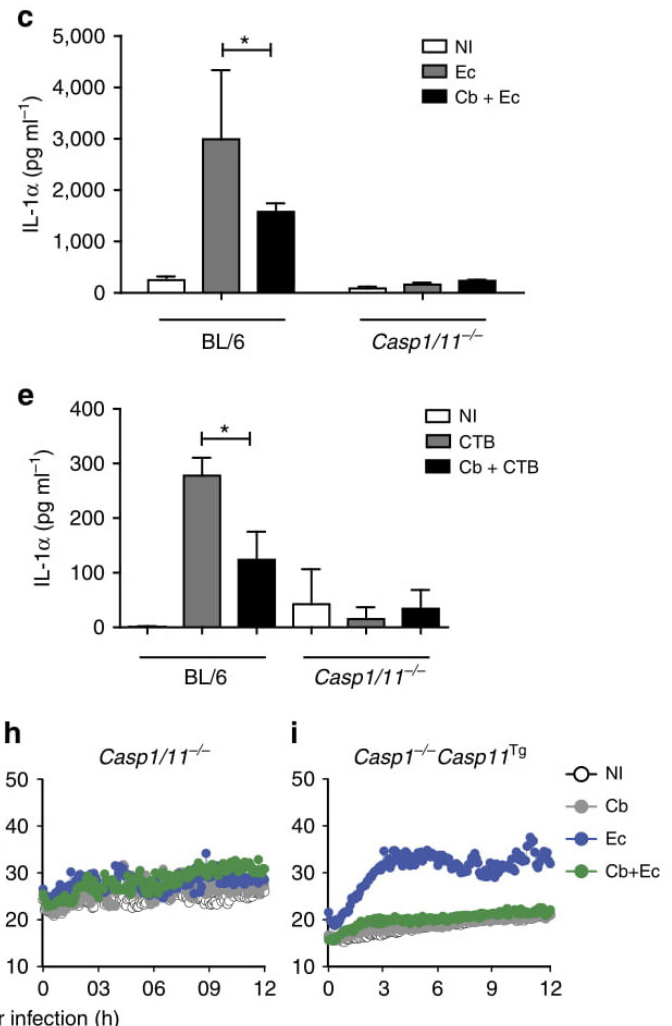

Figure 3 | C. burnetii inhibits caspase-11-dependent pore formation and NLRP3 activation in response to $\mathbf{E}$. coli and cholera toxin B. Bone marrowderived macrophages (BMDMs) generated from wild-type C57BL/6 (BL/6), N/rp3 ${ }^{-/-}$, Asc ${ }^{-/-}$or Casp1/11 ${ }^{-/-}$mice were left noninfected (NI) or were infected with C. burnetii ( $\mathrm{Cb}, \mathrm{MOI} 30)$ for $24 \mathrm{~h}$, stimulated with LPS $\left(0.5 \mu \mathrm{g} \mathrm{ml}{ }^{-1}\right)$ for $4 \mathrm{~h}$ and infected with $E$. coli at $\mathrm{MOI} 20$ (Ec or Cb + Ec) or treated with CTB at $20 \mu \mathrm{g} \mathrm{ml}^{-1}$ (CTB or Cb + CTB). (a) Immunoblot showing levels of processed p20 subunit of caspase-1 (caspase-1 p20), unprocessed caspase-1 (pro-caspase-1) and p17 subunit of mature IL-1 $\beta$ (IL-1 $\beta$ p17), as determined in supernatant (SN) and cell extract (CE) after $12 \mathrm{~h}$ of infection with E. coli. (b) IL-1 $\beta$ and (c) IL- $1 \alpha$ were determined by ELISA from cell supernatants $16 \mathrm{~h}$ after E. coli infection. (d) IL-1 $\beta$ and (e) IL-1 $\alpha$ were determined by ELISA from cell supernatants $16 \mathrm{~h}$ after CTB stimulation. (f-i) Pore formation was assessed fluorometrically in real time by the uptake of propidium iodide (RFUs, relative fluorescence units). (b-e) Data are expressed as the average \pm s.e.m. of triplicate wells and significance was calculated with ANOVA. ${ }^{\star} P<0.05$. (a-i) Data are representative of two independent experiments.

Casp $1^{-/-} / \operatorname{Casp} 11^{\mathrm{Tg}}$, is the Casp $1 / 11^{-/-}$expressing a transgene encoding a functional copy of the caspase-11 allele, as described previously ${ }^{53}$. By using Casp1 $1^{-/-} /$Casp $11^{T g}$ BMDMs, we confirmed that $C$. burnetii is able to inhibit caspase-11-mediated pore formation induced by $E$. coli in the absence of caspase-1 (Fig. 3i). Next, we tested whether the inhibition of caspase-11 also operates in primary mouse AMs, which are permissive for $C$. burnetii replication, and are more similar to the relevant cells that harbour $C$. burnetii during acute $Q$ fever
(Supplementary Fig. 4a). By using AMs, we found that co-infections with live $C$. burnetii but not with heat-killed bacteria inhibit the caspase-11-dependent pore formation induced by E. coli in primary AMs similarly to BMDMs (Supplementary Fig. 4b,c).

A genetic screen using L. pneumophila identifies C. burnetii IcaA. We used L. pneumophila as a surrogate host to screen the specific C. burnetii effector proteins involved in the inhibition of 
non-canonical inflammasome activation, and we constructed a library of $\mathrm{flaA}^{-}$mutants of L. pneumophila expressing C. burnetii effectors that have been confirmed to be secreted via the L. pneumophila type IV secretion system ${ }^{44,45}$. We obtained L. pneumophila clones with a confirmed expression of $24 \mathrm{C}$. burnetii effectors (Supplementary Fig. 5a,b). L. pneumophila mutants expressing $C$. burnetii genes were screened by western blot for the induction of caspase-1 cleavage in infected BMDMs. This screening identified a strain that induced neither caspase-1 activation nor IL-1 $\beta$ maturation, which was the clone of L. pneumophila that produces the effector protein annotated as CBU1823 (Supplementary Fig. 5c-e). Although biochemical activities displayed by the CBU1823 protein are yet unknown, this protein has been shown to be secreted into host cells through the L. pneumophila Dot/Icm system ${ }^{44,45}$. In addition, a recent report demonstrated that CBU1823 is translocated into BMDMs during $C$. burnetii infection in a process dependent on the C. burnetii Dot/Icm system ${ }^{55}$. Because we identified CBU1823 as a C. burnetii Dot/Icm effector protein that inhibits caspase activation, we named this protein IcaA. IcaA shows no known protein domain and has no significant homology to any other eukaryotic or bacterial protein to hint at its mechanisms of function.

We further tested whether the expression of IcaA in different strains of $\mathrm{flaA}^{-}$L. pneumophila displayed reduced caspase-1 cleavage in BMDMs. We found that the inhibition of caspase-1 cleavage by IcaA occurred in both JR32 and Lp01 backgrounds (Supplementary Fig. 6a). Inhibition also occurred when we used the strain Lp02, which is a thymidine auxotroph and does not replicate intracellularly in the absence of thymidine supplementation (Supplementary Fig. 6a). Hence, IcaA-mediated caspase-1 inhibition is independent of bacterial replication. Next, we investigated whether the expression of IcaA influenced L. pneumophila fitness. We compared $\mathrm{flaA}^{-}$mutants of L. pneumophila expressing IcaA ( $\left.f l a A^{-} / \mathrm{pIcaA}\right)$ with those encoding the empty vector $\left(f l a A^{-} / \mathrm{pVec}\right)$ in assays that measured replication in axenic media, internalization in BMDMs and the induction of cytokines. We found that the expression of IcaA does not affect the bacterial replication in liquid ACES-buffered yeast extract (AYE) axenic media, bacterial internalization in BMDMs or the induction of IL-12 in BMDMs (Supplementary Fig. 6b-d). Moreover, the expression of IcaA or the unrelated $C$. burnetii effector protein AnkH in $\mathrm{flaA}^{-}$L. pneumophila did not interfere with internalization or the early bacterial replication in BMDMs at $9 \mathrm{~h}$ of infection compared with the bacteria encoding the empty vector (Supplementary Fig. 6e,f). The bacteria encoding pIcaA, but not those encoding the pVec, showed a reduced activation of caspase-1 and secretion of IL-1 $\beta$ (Supplementary Fig. 6a,g).

Our studies, using pre-infections with live C. burnetii, supported the findings that $C$. burnetii inhibits the non-canonical activation of the inflammasome. Therefore, we used the $\mathrm{flaA}^{-}$ L. pneumophila-carrying pIcaA (or $\mathrm{pVec}$ ) to evaluate whether IcaA is involved in the inhibition of the caspase-11-mediated, non-canonical activation of the NLRP3 inflammasome. Initially, we investigated whether caspase-11 is required for the IcaA-mediated inhibition of caspase- 1 activation. We found that whereas $\mathrm{flaA}^{-}$mutants encoding $\mathrm{pVec}$ trigger caspase-1 activation in BL/6 BMDMs, the mutants expressing IcaA fail to do so. Importantly, the IcaA-mediated inhibition of caspase-1 activation is not observed in BMDMs from mice of a 129S6/SvEv genetic background (herein called 129), a strain that fails to express functional caspase-11 (Fig. 4a,b). To certify that the lack of caspase-1 inhibition in 129 mouse strains was due to the absence of caspase-11, we transduced 129 BMDMs with a retrovirus-encoding caspase-11 (or GFP as a control). The transduced cells expressed a significant amount of p43 and p38 isoforms of pro-caspase-11 (Fig. 4b). By infecting the transduced cells, we found that $\mathrm{flaA}^{-}$L. pneumophila expressing pIcaA inhibits the caspase-1 cleavage in 129 BMDMs expressing caspase-11 but not in cells transduced with retrovirus-encoding GFP (Fig. 4c). In agreement with these findings, we found that $\mathrm{flaA}^{-} / \mathrm{pIcaA}$ mutants do not inhibit caspase-1 cleavage or IL- $1 \beta$ secretion in LPS-primed Casp11 ${ }^{-/-}$BMDMs in the BL/6 genetic background (Fig. $4 \mathrm{~d}, \mathrm{e}$ ). In contrast, in the BL/6 BMDMs, IcaA expression partially inhibited caspase-1 activation and IL-1 $\beta$ secretion induced by $f l a A^{-}$L. pneumophila, which are convenient proxy measures for caspase-11 activation (Fig. 4d,e). Supporting the role of caspase-11 in the flagellin-independent pathway for caspase-1 activation, we found that BMDMs from Casp $11^{-1-}$ mice show a reduced activation of caspase-1 and secretion of IL-1 $\beta$ compared with BL/6 BMDMs (Fig. $4 \mathrm{~d}, \mathrm{e}$ ).

IcaA inhibits caspase-11-mediated inflammasome activation. Our data reported thus far indicate that IcaA is involved in the inhibition of a caspase-11-dependent, non-canonical activation of inflammasomes. Therefore, we tested whether IcaA interferes with a caspase-11-dependent process that is upstream of caspase1 . We have previously reported that caspase-11 is involved in the formation of pores in the macrophage membrane that are independent of NLRP3, ASC and caspase-1 (ref. 13). Therefore, we investigated whether $\mathrm{flaA}^{-}$mutants expressing IcaA interfere with caspase-11-mediated pore formation in BMDMs. By analysing the uptake of cell impermeable dye ethidium bromide, we found a partial reduction in pore formation in BMDMs infected with $\mathrm{flaA}^{-} / \mathrm{pIcaA}$ bacteria in comparison to those infected with $\mathrm{flaA}^{-} / \mathrm{pVec}$ (Fig. 5a,b). Next, we performed analyses using the less toxic dye propidium iodide (PI) to evaluate the kinetics of pore formation in real time. By using this approach, we confirmed that IcaA, but not the unrelated $C$. burnetii effector AnkH, partially inhibits the caspase-11-dependent pore formation observed in response to $\mathrm{flaA}^{-}$L. pneumophila (Fig. 5c). Pore formation was not detected in Casp11 1 or Casp1/11 $-1-$ BMDMs, emphasizing that the flagellinindependent pore formation is caspase-11-dependent (Fig. 5d,e). Notably, the IcaA-mediated inhibition of pore formation occurred normally in BMDMs from Nlrp3 $3^{-/}, A s c^{-/-}$and Casp $1^{-/-} /$Casp $11^{\mathrm{Tg}}$ mice (Fig. 5f-h). These data further confirm that IcaA interferes with caspase-11-mediated responses but not in the downstream components of the NLRP3 inflammasome, such as NLRP3, ASC and caspase-1. To further evaluate whether the IcaA-mediated inhibition of pore formation is specific to caspase-11, we expressed IcaA in flagellated L. pneumophila, which is known to trigger pore formation by a process that is Nlrc4- and caspase-1-dependent but caspase-11independent ${ }^{10,13,52,54,56,5}$. By infecting BMDMs from BL/6, Casp11 $1^{-/-}$and Caspl/11 $1^{-/-}$mice with $\mathrm{flaA}^{+} / \mathrm{pIcaA}$ or $\mathrm{flaA}^{+} / \mathrm{pVec}$, we found that the IcaA is not effective in inhibiting the flagellin-mediated pore formation that is dependent on caspase-1 but independent of caspase-11 (Supplementary Fig. 7a). As expected, infections performed with llaA $^{-} / \mathrm{pIcaA}$ inhibited caspase-11-dependent pore formation compared with $\mathrm{flaA}^{-} / \mathrm{pVec}$ (Supplementary Fig. 7b). All these data indicate that IcaA is specifically involved in the inhibition of caspase-11-mediated processes, but it does not influence caspase-1-mediated processes that do not require caspase-11. Our assertion that C. burnetii inhibits a caspase-11dependent pathway implies that the bacteria express molecules that trigger this pathway. To evaluate whether $C$. burnetii is able to trigger caspase-11 activation, we extracted C. burnetii LPS and tested for the induction of pore formation upon 
a

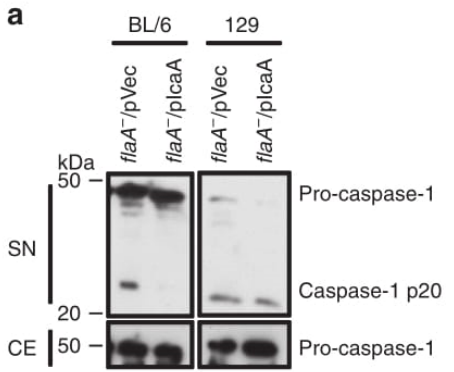

b

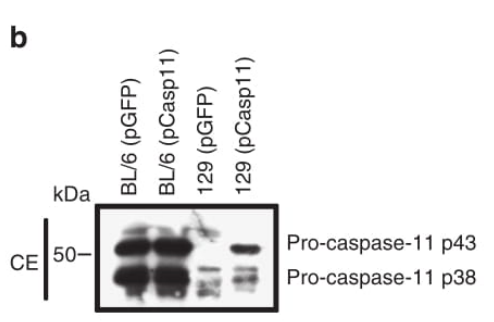

d

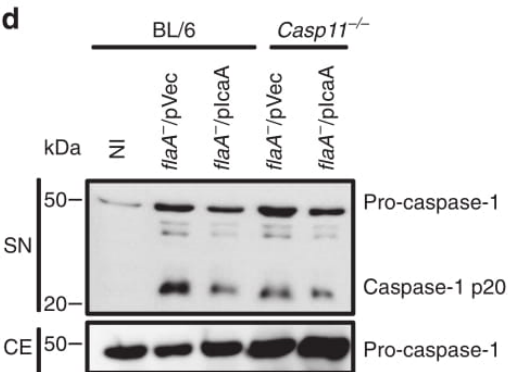$$
\text { CE }
$$

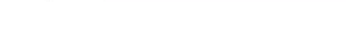

c

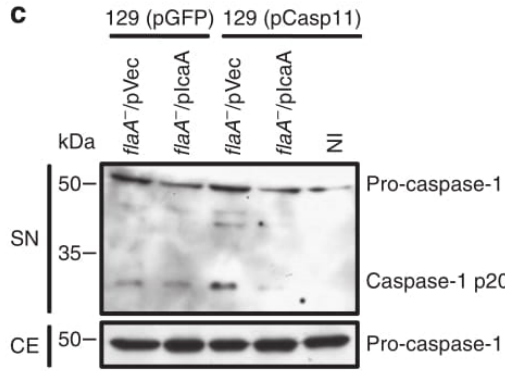

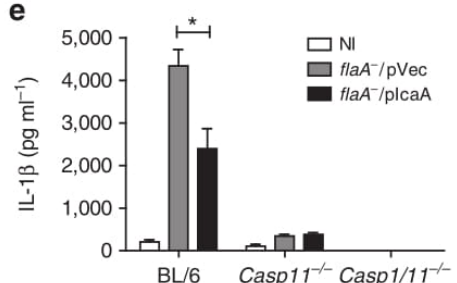

Figure 4 | IcaA requires a functional caspase-11 to inhibit caspase-1 activation. Bone marrow-derived macrophages (BMDMs) generated from C57BL/6 (BL/6) and 129S6/SvEv (129) mice were left noninfected (NI) or were infected with flaA ${ }^{-}$mutants of $L$. pneumophila that were transformed either with an empty vector $\left(\mathrm{flaA}^{-} / \mathrm{pVec}\right.$ ) or the vector encoding IcaA (flaA-/plcaA) at $\mathrm{MOI} 10$ for $9 \mathrm{~h}$. (a) Immunoblot showing processed p20 subunit of caspase-1 (caspase-1 p20) and unprocessed caspase-1 (pro-caspase-1), as determined in supernatant (SN) and cell extract (CE). (b) Immunoblot showing the expression of unprocessed isoforms of pro-caspase-11 ( $\mathrm{p} 43$ and $\mathrm{p} 38$ ) in uninfected BL/6 and caspase-11-deficient BMDMs derived from 129 mouse strain were transduced with the pMSCV virus encoding GFP (pGFP) or pMSCV encoding full-length caspase-11 (pCasp-11). The expression of unprocessed isoforms of pro-caspase-11 (p43 and p38) is shown by western blot. (c) Immunoblot showing caspase-1 p20 and pro-caspase-1 as determined in SN and CE from transduced BMDMs infected for $9 \mathrm{~h}$. (d) Immunoblot showing caspase-1 p20 and pro-caspase-1 in SN and CE of BMDMs primed with LPS $\left(0.5 \mu \mathrm{g} \mathrm{ml}^{-1}\right)$ and infected for $3 \mathrm{~h}$. (e) IL-1 13 was determined by ELISA from SN of BMDMs primed with LPS for $3 \mathrm{~h}$. Data are expressed as the average \pm s.e.m. of triplicate wells and significance was calculated with ANOVA. ${ }^{\star} P<0.05$. Data are representative of at least two $(\mathbf{b}, \mathbf{c})$ or three $(\mathbf{a}, \mathbf{d}, \mathbf{e})$ independent experiments.

the transfection of BMDMs. We detected a robust pore formation in BMDMs transfected with C. burnetii LPS, which was reduced in Casp $1^{-1-} /$ Casp $11^{T g}$ and Casp11 ${ }^{-/-}$BMDMs (Supplementary Fig. 8). These data support the hypothesis that C. burnetii expresses molecules that trigger pore formation if delivered in the macrophage cytoplasm, a feature that supports the development of effectors, such as IcaA, to inhibit this response.

Our data generated thus far indicate that IcaA is an effector protein encoded by $C$. burnetii that mediates the inhibition of caspase-11 functions such as pore formation, but it is not clear whether IcaA inhibits caspase-11 activation. Thus, we tested whether IcaA-expressing flaA ${ }^{-} L$. pneumophila can reduce the activation of caspase-11 in the infected BMDMs. To measure caspase-11 activation directly, we pulled down active caspase-11 from macrophages lysates using biotin-VAD-FMK. Active caspase-11-bound to biotin-VAD was concentrated with streptavidin, and the samples were blotted with anti-caspase-11.
We detected a robust caspase-11 activation when BL/6 BMDMs were infected with $\mathrm{flaA}^{-}$L. pneumophila (Fig. 5i). Notably, IcaA expression in L. pneumophila reduced caspase-11 activation compared with the bacteria expressing the empty vector (Fig. 5i). The IcaA-mediated inhibition of caspase-11 activation was also observed in experiments performed with macrophages from the Casp $1^{-/} /$Casp $11^{T g}$ mice (Fig. 5i). Notably, the overall expression of caspase-11 in these cells is lower than that of C57BL/6 macrophages, possibly because only one copy of the Casp11 ${ }^{\text {tg }}$ is present in the genome. Regardless of the reduced expression of caspase-11 in the Casp $1^{-/-} /{\text {Casp } 11^{T g}}^{T}$ BMDMs, these data further confirm our assertion that IcaA is involved in the inhibition of caspase-11 activation despite the presence of caspase-1 (Fig. 5e).

icaA- C. burnetii fails to inhibit inflammasome activation. To further evaluate whether the endogenously expressed IcaA in 


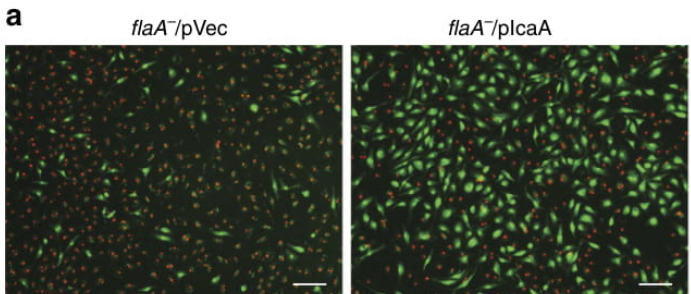

BL/6
$\mathrm{flaA}^{-} / \mathrm{pVec}$

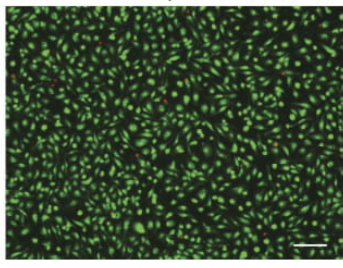

Casp $1 / 11^{-1-}$

b

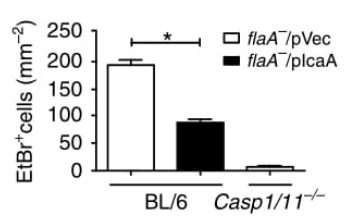

c
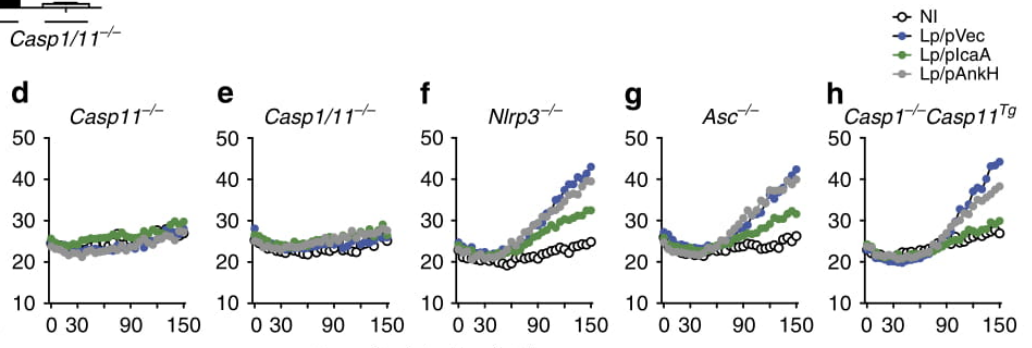

i

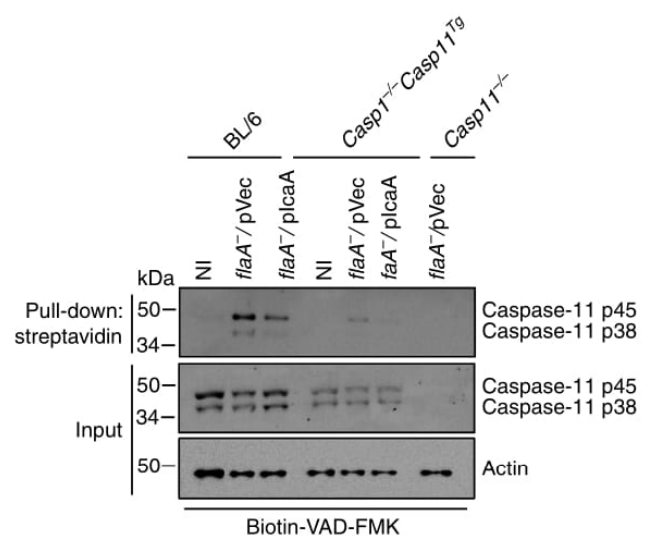

Figure 5 | IcaA does not inhibit caspase-11 activation directly but inhibits a caspase-11 activation upstream of the non-canonical activation of the NLRP3 inflammasome. (a-i) Bone marrow-derived macrophages (BMDMs) were primed with LPS $\left(0.5 \mu g \mathrm{ml}^{-1}\right)$ for $3 \mathrm{~h}$, remained noninfected (NI) or were infected with flaA- L. pneumophila transformed either with an empty vector (flaA- $/ \mathrm{pVec}$ ), the vector encoding IcaA (flaA ${ }^{-} / \mathrm{plcaA}^{-}$), or the vector encoding AnkH (fla $A^{-} / \mathrm{pAnkH}$ ) at $\mathrm{MOI}$ 10. (a) Fluorescence micrographs revealing cell permeability, as assessed by quantification of ethidium bromide influx (red). Healthy cells are stained with acridine orange (green). Scale bar, $75 \mu \mathrm{m}$. (b) Quantification of the experiment shown in (a). Data are expressed as the average \pm s.e.m. of triplicate wells and significance was calculated with $t$-test. ${ }^{\star} P<0.05$. (c-h) Pore formation was assessed fluorometrically in real time by the uptake of propidium iodide (RFUs, relative fluorescence units). (i) Immunoblot showing the presence of caspase-11 p45 and p38 in the total cell lysate (input) and pull-down fraction using the agarose-streptavidin fraction of BMDMs treated with biotin-VAD-FMK 15 min before infection. Actin $(\beta$-actin) was used as a loading control. Data are representative of three (a-h) and two (i) independent experiments.

C. burnetii is involved in the inhibition of the inflammasome activation, we generated the $i c a A^{-}$mutant $C$. burnetii (Supplementary Fig. 9). Initially, we tested whether $i c a A^{-}$is able to trigger caspase-11-dependent responses in single macrophage infections. Measuring caspase-11-dependent pore formation in cells infected with C. burnetii, we found that neither the wild-type C. burnetii nor the $i c a A^{-}$mutants triggered a caspase-11dependent pore formation (Fig. 6a). Accordingly, icaA mutants failed to trigger the caspase-11-mediated non-canonical activation of the NLRP3 inflammasome, as measured by the production of IL-1 $\beta$ (Fig. 6b). These data suggest that additional C. burnetii processes may be involved in the activities related to the inhibition of inflammasome activation by this bacterium. Next, we tested whether IcaA expression is required for the inhibition of non-canonical inflammasome activation in co-infection experiments. In these experiments, $\mathrm{Nlrc4}^{-/-}$BMDMs or flaA ${ }^{-}$ 
a

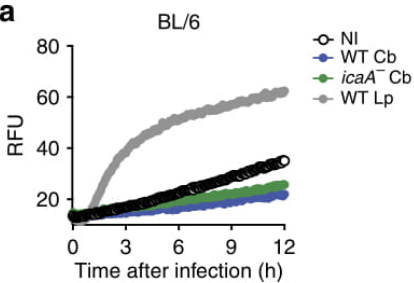

C

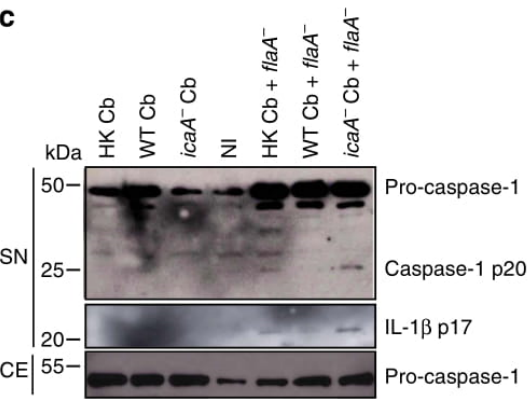

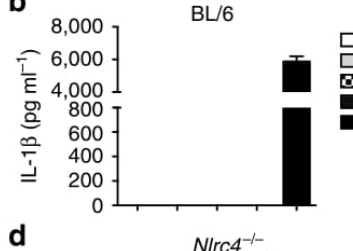

d

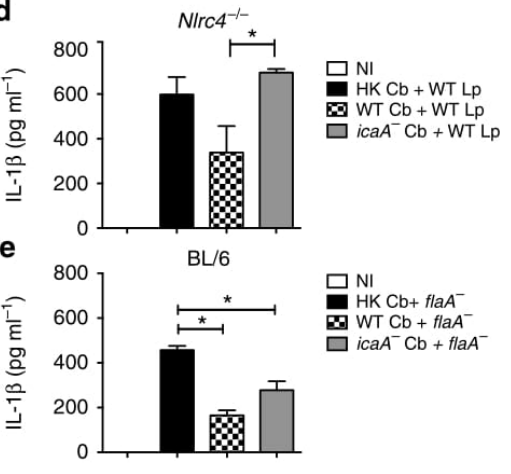

Figure 6 | C. burnetii mutants for icaA fail to inhibit the non-canonical activation of the inflammasome in response to flaA ${ }^{-} L_{\text {. pneumophila. Bone }}$ marrow-derived macrophages (BMDMs) were left noninfected (NI) or were infected with heat-killed wild-type (HK $\mathrm{Cb}$ ) wild-type (WT Cb) or icaA mutant (icaA- $\mathrm{Cb}$ ) of $\mathrm{C}$. burnetii for $24 \mathrm{~h}$ at $\mathrm{MOI} 30$, and further infected with wild-type L. pneumophila (WT Lp, MOI 10) or flaA $\mathrm{A}^{-}\left(\mathrm{MOI}^{10}\right)$ for $9 \mathrm{~h}$. Co-infected BMDMs are indicated $\left(\mathrm{Cb}+\mathrm{Lp}\right.$ or $\left.\mathrm{Cb}+\mathrm{flaA}^{-}\right)$. (a) Pore formation was assessed fluorometrically in real time by the uptake of propidium iodide (RFUs, relative fluorescence units). (b,d,e) IL-1 $\beta$ secretion in infected BMDMs was determined by ELISA. Data are expressed as the average \pm s.e.m. of triplicate wells and significance was calculated with $t$-test. ${ }^{*} P<0.05$. (c) Immunoblot showing processed p20 subunit of caspase-1 (caspase-1 p20), unprocessed

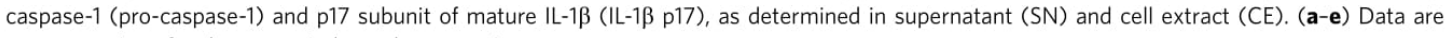
representative of at least two independent experiments.

L. pneumophila were used to bypass the activation of NLRC4 inflammasome. We found that, whereas a single infection with wild-type $C$. burnetii or with the $i c a A^{-}$mutants did not trigger caspase-1 activation in BMDMs, the co-infection with icaA ${ }^{-}$ C. burnetii failed to suppress the caspase-1 activation induced by $\mathrm{flaA}^{-}$L. pneumophila (Fig. 6c). Accordingly, co-infections performed with wild-type $C$. burnetii, but not with icaA mutants, inhibited the caspase-11-mediated non-canonical activation of the inflammasome, as measured by IL- $1 \beta$ production (Fig. $6 \mathrm{~d}, \mathrm{e}$ ). These data further confirm that endogenously expressed IcaA in C. burnetii is important for the activities related to the inhibition of the caspase-11-mediated non-canonical activation of the inflammasome.

\section{Discussion}

It is estimated that as few as five infectious C. burnetii organisms are able to establish infection in healthy individuals exposed to the bacteria ${ }^{58}$. To achieve such a high infectious efficiency, C. burnetii inhibits a large repertoire of specific host cell responses, including those related to the innate immune activation and induction of host cell death. Although the inhibition of caspase-3-mediated apoptosis by $C$. burnetii has been reported previously $29,31,32,35$, an evaluation of inflammatory caspases and pyroptosis has never been conducted. Herein, we report that $C$. burnetii fails to induce caspase- 1 activation upon the infection of primary mouse macrophages. We found that the bacteria actively inhibit the caspase-11 activation and their functions including pore formation and the non-canonical activation of the NLRP3 inflammasome, but they do not inhibit the components of inflammasomes such as ASC, NLRP3 or caspase-1. By searching for the molecular mechanisms underlying this process, we identified a novel C. burnetii gene that encodes an

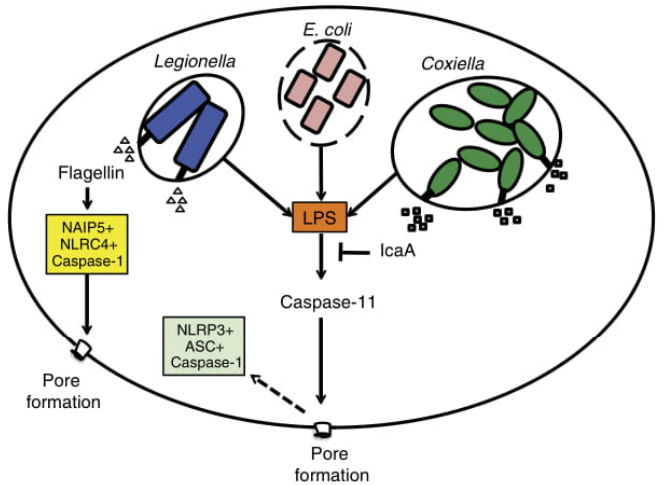

Figure 7 | Model for IcaA-mediated inhibition of non-canonical activation of the inflammasome. Published data demonstrate that caspase-11 senses the presence of cytosolic LPS from Gram-negative bacteria, including E. coli and $L$. pneumophila. Activation of caspase-11 in response to L. pneumophila requires the expression of Dot/Icm. The effector protein IcaA is translocated by the $C$. burnetii Dot/Icm and inhibits the caspase-11mediated pore formation and caspase-11-induced non-canonical activation of the NLRP3 inflammasome.

effector protein translocated by the Dot/Icm type IVB secretion system into host cell cytosol. We named this protein IcaA because it is functionally related to the inhibition of caspase activation. IcaA suppresses the caspase-11-mediated, non-canonical activation of caspase-1 in macrophages. Notably, we have no data to support a direct effect of IcaA in the inhibition of caspase11 activation. Most likely, IcaA is involved in the inhibition of 
certain cellular processes, which leads to caspase-11 activation (Fig. 7). It is also possible that IcaA operates in the vacuolar membranes by minimizing the release of bacterial molecules from the vacuole to the cytoplasm, thereby reducing the release of PAMPs that trigger cytosolic innate immune sensors. This hypothesis is consistent our observed ability to transfer the C. burnetii inhibitory activity to L. pneumophila in trans when IcaA was expressed in L. pneumophila. This was achieved because of the high homology of $C$. burnetii and L. pneumophila Dot $/ \mathrm{Icm}^{40}$. In fact, $L$. pneumophila has been extensively used as an effective surrogate host to investigate $C$. burnetii pathogenesis. Earlier studies demonstrated that the structural core components of the C. burnetii Dot/Icm can complement L. pneumophila mutants deficient in the respective homologous gene ${ }^{41,42}$. Further studies benefited from the high homology between the two Dot/ $\mathrm{Icm}$ and used $L$. pneumophila to actively translocate C. burnetii effector proteins ${ }^{44-50}$. This approach supported the identification of several effector proteins encoded by C. burnetii, including the protein encoded by gene CBU1823 (refs 44,45). However, only recently has the secretion of $C$. burnetii effectors via $C$. burnetii Dot/Icm been efficiently detected experimentally ${ }^{45}$. Notably, CBU1823 (IcaA) was one protein that has been used to demonstrate the functional activities of the C. burnetii Dot/Icm; therefore, IcaA is a bona fide effector secreted by the C. burnetii Dot/Icm system into the host cell cytoplasm ${ }^{55}$. These data demonstrate that IcaA is a bona fide substrate of the C. burnetii Dot/Icm, which can be translocated by the Legionella $D o t / I c m$ or by the Coxiella $\operatorname{Dot} / \mathrm{Icm}^{44,45,55}$.

The genetic manipulation of $C$. burnetii has only recently been achieved ${ }^{44,59}$. Therefore, little information is available regarding the role of specific C. burnetii effector proteins. It is believed that the bacterial effectors are determinants in the pathogenesis of this bacterium. A functional Dot/Icm system is required for C. burnetii growth in macrophages and in permissive cells, supporting an essential role of translocated effector proteins for bacterial survival ${ }^{44,59}$. By random transposon mutagenesis, several putative effectors have been shown to be important for bacterial replication ${ }^{48}$. Moreover, the deletion of CvpA, an effector that interacts with components of clathrin-coated endocytic vesicles, impairs the maturation of the parasitophorous vacuole and bacterial growth $^{30}$. The gene-encoding IcaA studied herein was identified in the Nine Mile strain of C. burnetii, which is representative of acute disease isolates. Analysis of the genome of other important C. burnetii strains showed that this effector is conserved in the Dugway ${ }^{44}$, a strain isolated from rodents that is weakly pathogenic for guinea pigs. Notably, IcaA is encoded in truncated forms in the human endocarditis isolates $\mathrm{K}(\mathrm{Q} 154)$ and G (Q212) strains ${ }^{44}$. Whether the IcaA is non-functional in $\mathrm{K}$ and $\mathrm{G}$ strains due to frameshift mutations and whether this reflects differences in the virulence and spreading of the bacteria to other tissues is a subject for future investigation. Notably, caspase-11-induced susceptibility to infection has been demonstrated in murine models of bacterial dissemination using Salmonella typhimurium ${ }^{60}$. In this context, it remains to be determined whether the IcaA-mediated inhibition of caspase-11 and pyroptosis regulates bacterial dissemination and accounts for the development of chronic versus acute $\mathrm{Q}$ fever. Another matter for further investigation is the effect of $i c a A$ in inflammasome activation within human macrophages. It was recently demonstrated that Nine Mile phase II can trigger the production of active IL-1 $\beta$ in primary human $\mathrm{AMs}^{61}$. Although we have demonstrated that the IcaA-mediated inhibition of caspase-11 activation also occurs in primary mouse AMs, a direct comparison with primary human AMs will be important for the comprehensive assessment of the role of IcaA in the bacterial pathogenesis and host responses during $\mathrm{Q}$ fever. Nonetheless, the fact that primary human macrophages do trigger IL-1 $\beta$ production $^{6}$ supports our findings that C. burnetii does encode molecules responsible for the non-canonical activation of the inflammasome.

Regardless of the determination of the role of IcaA and caspase-11 in the outcome of C. burnetii infection in vivo, our study identifies IcaA as a novel bacterial substrate that participates in the inhibition of non-canonical inflammasome activation. To the best of our knowledge, this is the first bacterial effector that interferes with pyroptosis and the activation of the non-canonical inflammasome activation in macrophages ${ }^{19}$. By using epithelial cells, OspC3 was identified as a Shigella flexneri effector protein that functions as a direct inhibitor of human caspase-4 (ref. 62). This protein was shown to be important for bacterial pathogenesis using a guinea pig model of $S$. flexneri infection. However, it remains unclear whether OspC3 operates in macrophages and whether it interferes with the non-canonical activation of the inflammasome. Regardless of the effect of OspC3 in human epithelial cells, we propose that the C. burnetii effector protein IcaA interferes with the process involved in caspase-11 activation, consequently inhibiting non-canonical inflammasome activation in macrophages, a molecular platform that has recently emerged as major player in innate immune responses to Gram-negative bacteria ${ }^{12-18,53}$. C. burnetii does not inhibit caspase-1 or other inflammasomes such as the NAIP5/NLRC4 or the canonical NLRP3. Because C. burnetii does not encode genes for flagellin expression, the bacteria may not have encountered selective pressure to develop molecules that target the activation of the NAIP5/NLRC4 inflammasome. In contrast, C. burnetii virulence is associated with the presence of the $\mathrm{O}$-antigen in its LPS containing a tetra-acylated lipid A with long fatty acid chains ${ }^{39}$. Because it has been recently reported that the non-canonical activation of the inflammasome proceeds through the intracellular recognition of cytosolic LPS ${ }^{16,17}$, it is possible that the C. burnetii LPS triggers this pathway, and the bacterium has evolutionary evolved effectors, such as IcaA, that facilitate the subversion of this important innate immune pathway. In support of this hypothesis, we found that the delivery of $C$. burnetii LPS into the macrophage cytoplasm triggers this pathway. Notably, tetra-acylated lipid A was reported to be inefficient for activating caspase-11 (ref. 16). It is possible that variations in the Coxiella lipid A occur according to the bacterial growth phase. Alternatively, it is possible that another bacterial molecule is responsible for triggering caspase-11-dependent pore formation. Nonetheless, the induction of pores in macrophages transfected with $C$. burnetii LPS indicates that $C$. burnetii can trigger a pathway that is inhibited by IcaA. Collectively, the identification of IcaA and the unravelling of its mechanistic functions effectively contribute to our understanding of the biology and pathogenesis of this highly infectious intracellular pathogen and provides novel molecular structures that can be used in the development of therapies for sepsis and chronic inflammatory diseases.

\section{Methods}

Bacterial strains. C. burnetii (strain Nine Mile RSA 493 phase II) were collected and purified from the infection of irradiated Vero cell monolayers in DMEM (Sigma-Aldrich) supplemented with $5 \%$ fetal bovine serum (FBS) at $37^{\circ} \mathrm{C}$ in $5 \% \mathrm{CO}_{2}$ (ref. 63). Legionella pneumophila. Wild-type (WT Lp) and isogenic $5 \% \mathrm{CO}_{2}$ (ref. 63). Legionella pneumophila. Wild-type (WT Lp) and isoge
flagellin-deficient mutants $\left(\right.$ flaA ${ }^{-}$) of L. pneumophila Lp02 (thymidine flagellin-deficient mutants $\left(f l a A^{-}\right)$of $L$. pneumophila Lp02 (thymidine
auxotrophic derivative from serogroup 1 strain Lp01) ${ }^{64}$ were used for co-infection assays. For the surrogate expression of C. burnetii effectors, WT Lp, flaA ${ }^{-}$and $\operatorname{dot} A^{-}$isogenic mutants from Lp01 (ref. 64) and flaA ${ }^{-}$isogenic mutants of Lp02 (ref. 64) and JR32 (ref. 65) strains were transformed as described below. L. pneumophila was cultivated at $37^{\circ} \mathrm{C}$ on MOPS-buffered charcoal-yeast extract (CYE) agar plates $(1 \%(\mathrm{w} / \mathrm{v})$ yeast extract, $1 \%(\mathrm{w} / \mathrm{v})$ MOPS, $3.3 \mathrm{mM}$ L-cysteine, $0.33 \mathrm{mM} \mathrm{Fe}\left(\mathrm{NO}_{3}\right), 1.5 \%$ (w/v) Bacto agar and $0.2 \%$ (w/v) activated charcol, pH 6.9) supplemented with $100 \mu^{\prime g ~ m l}{ }^{-1}$ thymidine, as appropriate. E. coli (DH5 $\alpha$ strain) was streaked at $37^{\circ} \mathrm{C}$ on Luria-Bertani (LB) agar plates without 
antibiotics for colony isolation and cultivated in LB broth at $37^{\circ} \mathrm{C}$ under rotation (200 r.p.m.).

Mice. C57BL/6, 129S6/SvEv and C57BL/6-derived $\mathrm{Asc}^{-1-}$, Casp11 ${ }^{-1-}$

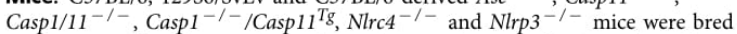
and maintained under specific pathogen-free conditions in the Animal Facilities of the Medical School Ribeirão Preto (FMRP-USP). Casp1 $1^{-/-} /$Casp $11^{T g}$ mice are Casp $1 / 11^{-1-}$ mice expressing a transgene encoding a functional copy of the caspase-11 allele, as described previously ${ }^{53}$. Male or female mice with 8-12 weeks old were used. All mouse experiments were conducted according to the guidelines of the institutional committee for animal care at the Comissão de Ética em Experimentação Animal da Faculdade de Medicina de Ribeirão Preto, FMRP-USP.

Plasmid construction and expression of Dot/lcm effectors of $C$. burnetii in L. pneumophila. The $\mathrm{pSN} 85 / \mathrm{Cm}^{+}$plasmid with a $\mathrm{N}$-terminal Flag epitope tag was used to clone Dot/Icm effectors from C. burnetii (strain Nine Mile RSA 493 phas II). Full-length genes of effectors annotated as CBU were subcloned from pEC33 constructs $^{44}$ through BamHI and PstI sites. Full-length genes of effectors annotated as Ank were amplified from purified genomic DNA ${ }^{44}$ by PCR with sequence-specific primers containing BamHI and SphI sites or XbaI and SphI in the case of AnkB (all primers used in this study are provided in Supplementary Table 1). For AnkJ, genomic DNA from the Dugway isolate was amplified by PCR with sequence-specific primers containing BamHI and SphI sites. Following heatshock transformation and amplification in E. coli (DH5 $\alpha$ strain), the constructs shock transformation and amplification in $E$. coli (DH5 $\alpha$ strain), the constructs
were purified with a NucleoSpin plasmid kit (Macherey-Nagel) and subsequently used to transform L. pneumophila by electroporation. Transformed L. pneumophila clones were selected and expanded in CYE plates with $10 \mu \mathrm{g} \mathrm{ml}^{-1}$ chloramphenicol. Effector expression was induced with the addition of $1 \mathrm{mM}$ isopropyl $\beta$-D-1-thiogalactopyranoside (IPTG, Invitrogen) to plates and confirmed by immunoblot using an anti-Flag antibody (Sigma-Aldrich).

Construction of $\mathrm{icaA}^{-}$mutants of $\mathbf{C}$. burnetii. A PCR product consisting of CBU1823 and $2 \mathrm{~kb}$ of DNA flanking either end was amplified from C. burnetii (Nine Mile RSA 493 phase II) genomic DNA by using PfuUltra II Fusion HotStart DNA polymerase (Agilent Technologies). The product was ligated into the BamHI and Sall sites of pJC-CAT. The resulting construct, PJC-1823FL, was then used as template in a PCR. The resulting PCR product was then gel purified and digested with NotI-HF (New England Biolabs) and ligated with the kanamycin resistance gene amplified from pJB-Kan. The ligation mix was then transformed into DH5 The resulting construct, pJC1823KO, in which the CBU1823 gene was replaced with a kanamycin resistance gene, was then used in the gene knockout experiment ${ }^{66}$. CBU1823 knockout was confirmed by Southern hybridization using probes directly binding to $\mathrm{CBU} 1823$ and the kanamycin resistance cassette.

Bone marrow-derived and alveolar macrophages. AMs were obtained by bronchoalveolar lavage with warm PBS containing 5 mM EDTA. AMs were washe twice with PBS, seeded on tissue culture plates with RPMI 1640 media $10 \%$ FBS, $2 \mathrm{mM}$ L-glutamine and cultivated at $36^{\circ} \mathrm{C}, 5 \% \mathrm{CO}_{2}$. C. burnetii replication in AM was assessed by quantitative PCR, as described previously ${ }^{67}$. Bone marrow cells were collected from femurs and differentiated with RPMI 1640 (Sigma-Aldrich), $20 \%$ FBS (Invitrogen), 30\% L-929 cell-conditioned media (LCCM), $2 \mathrm{mM}$ L-glutamine (Sigma-Aldrich) and $100 \mathrm{U} \mathrm{ml}^{-1}$ penicillin-streptomycin (SigmaAldrich) cultivated at $36{ }^{\circ} \mathrm{C}, 5 \% \mathrm{CO}_{2}$. BMDMs were collected and seeded on tissu culture plates and kept in RPMI 1640 media 10\% FBS, 5\% LCCM and $2 \mathrm{mM}$ L-glutamine ${ }^{68}$

Construction of retroviral expression vectors and transduction of BMDMs. Full-length genomic C57BL/6 Casp11 was amplified by PCR with sequence-specific primers containing NotI and XhoI sites for cloning into PCDNA3.1/Hygro ${ }^{+}$vecto (Invitrogen). Casp11 was subsequently subcloned into a pMSCV2.0 murine-specific retroviral vector after the digestion of the purified pCDNA3 construct with Not and SalL $\mathrm{PCL}$ vector system ${ }^{69}$ for packaging retroviruses was co-transfected with MSCV-Cos 11-IRES-GFP using polyethin seak cells ATCC) maintained in RPMI 1640 with $10 \% \mathrm{FBS}$ at $36^{\circ} \mathrm{C}$ and $5 \% \mathrm{CO}_{2}$. BMDMs in day 3 of differentiation were collected, spun down and resuspended in retrovirus-containing peak cell supernatant supplemented with RPMI 1640 containing $20 \%$ FBS and 25\% LCCM. Cell transduction was confirmed by fluorescence microscopy. BMDMs were then collected, seeded on tissue culture plates one day before infection and kept in RPMI 1640 media 10\% FBS and 5\% LCCM.

Infection conditions. C. burnetii from frozen stocks was thawed at $37^{\circ} \mathrm{C}$. L. pneumophila single colonies were seeded and grown for 2 days in CYE agar plates, collected, diluted in distilled water and quantified by measuring optical density (OD) at $600 \mathrm{~nm}$. L. pneumophila mutants expressing C. burnetii effectors were infected in the presence of $1 \mathrm{mM}$ IPTG. E. coli single colonies were grown in $\mathrm{LB}$ broth for $8 \mathrm{~h}$ and quantified by measuring OD at $600 \mathrm{~nm}$. E. coli-infected macrophages were washed twice with warm PBS one hour after infection, and the media were replaced with media containing gentamicin (Sigma-Aldrich, $50 \mu \mathrm{g} \mathrm{ml}^{-1}$ ). When necessary, the plates were centrifuged for $15 \mathrm{~min}$ at $300 \mathrm{~g}$ to ensure the comparable adhesion of the bacteria to the cells.

Extraction of C. burnetii LPS. LPS was extracted using a modified hot phenol method, as described previously ${ }^{70}$. Briefly, $10^{6} \mathrm{C}$. burnetii were suspended in $1 \mathrm{~m}$ of $50 \%$ phenol $(\mathrm{pH} 8.8)$, boiled for $10 \mathrm{~min}$, incubated for $5 \mathrm{~min}$ on ice and then centrifuged at $14,000 \mathrm{~g}$ for $5 \mathrm{~min}$. The aqueous phase was collected, and the extraction was repeated on the pellet. The aqueous phases from both extractions were pooled and vacuum dried for $17 \mathrm{~h}$. The pellet was dissolved in $100 \mu \mathrm{l}$ of ultra-pure distilled $\mathrm{H}_{2} \mathrm{O}$. The LPS content after extraction was estimated by phenol-sulfuric acid method of carbohydrate quantification. Approximately, $1 \mu \mathrm{g} \mathrm{ml}^{-1}$ of C. burnetii LPS were used to transfect BMDMs using DOTAP (Roche) according to the manufacturer's instructions.

Determination of $L$. pneumophila number per Legionella-containing vacuole (LCV). BMDMs were cultivated in coverslips and fixed with $4 \%$ PFA after infection. The coverslips were immunostained with rabbit anti-Legionella $(1: 2,000)$ and tion. The coverslips were immunostained with rabbit anti-Legionella $(1: 2,000)$ and
goat anti-rabbit IgG Alexa Fluor 488 (Molecular Probes), mounted in glass slides goat anti-rabbit IgG Alexa Fluor 488 (Molecular Probes), mounted in glass slide
with ProLong Gold containing DAPI (Molecular Probes). The coverslips were analysed with a fluorescence microscope (Leica, Germany), and the number of bacteria per LCV was estimated visually.

Immunoblot analysis. BMDMs were lysed with a RIPA buffer $(10 \mathrm{mM}$ Tris- $\mathrm{HCl}$ (pH 7.4), $1 \mathrm{mM}$ EDTA, $150 \mathrm{mM} \mathrm{NaCl}, 1 \%$ Nonidet P-40, $1 \%$ (w/v) sodium deoxycholate and $0.1 \%(\mathrm{w} / \mathrm{v})$ SDS) supplemented with a protease inhibitor cocktail. Precleared lysates and supernatants were boiled with Laemmli buffer, resolved by SDS-polyacrylamide gel electrophoresis and transferred to a $0.22-\mu \mathrm{m}$ nitrocellulose membrane (GE Healthcare). Rat anti-caspase-1 p20 monoclonal antibody clone 4B4 (Genentech, 1:500), mouse anti-caspase-1 pl0 (Santa Cruz Biotechnology, $1: 250$ ), goat anti-IL-1 $\beta$ p17 subunit (Sigma-Aldrich, 1:250), rat anti-caspase-11 p10 (Abcam, 1:500) and rabbit anti-beta actin (Sigma-Aldrich, 1:5,000) were used for antigen detection. To detect the expression of Flag-fused effectors by L. pneumophila, bacterial heavy patches streaked from CYE plates after 2 days of growth in the presence of $1 \mathrm{mM}$ IPTG were boiled in Laemmli buffer, immunoblotting was carried out as described above, and anti-Flag M2 (Sigma-Aldrich, 1:5,000) antibody was used for antigen detection.

Reagents for cell stimulation and cytokine determination. Ultra-pure LPS (E. coli $\mathrm{K} 12)$ and poli I:C were from Invivogen. Tumour-necrosis factor- $\alpha$ was from eBioscience. ATP, nigericin and CTB were from Sigma-Aldrich. Cytokines from supernatants of the BMDM culture were detected by ELISA (OptEIA, BD Biosciences), according to the manufacturer's instructions.

Membrane pore formation assay. Pore formation in BMDMs and AMs was quantified by the permeability to ethidium bromide in damaged cells ${ }^{57}$. Images were acquired with a fluorescence microscope (Leica, Germany), five fields per coverslip. Pore formation was quantified using ImageJ software (NIH). For the kinetics of pore formation, the uptake of PI in infected cells was evaluated ${ }^{13}$. BMDMs were seeded in a black, clear-bottom 96-well plate. Before infection or stimulation, BMDMs were washed with warm PBS, and the media were replenished with RPMI $10 \%$ without phenol red, $0.038 \mathrm{~g} \mathrm{ml}^{-1} \mathrm{NaHCO}_{3}$, $6 \mu \mathrm{g} \mathrm{ml}^{-1} \mathrm{PI}$. Infected BMDMs were kept at $37^{\circ} \mathrm{C}$, and PI was excited at $538 \mathrm{~nm}$.

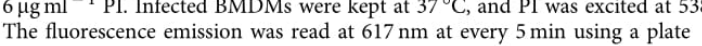
fluorometer (FlexStation 3, Molecular Devices).

FLICA staining and flow cytometry analysis. BMDMs were stained with caspase-1 FLICA probe (FAM-YVAD-FMK), as recommended by the manufacturer. HEK293 reporter cells were likewise stained with a pan-caspase FLICA probe (carboxyfluorescein-VAD-fluoromethylketone, FAM-VAD-FMK; ImmunoChemistry Technologies). Data from 30,000 events were acquired on a FACSCanto II (BD Biosciences) and were analysed with FlowJo software (Tree Star).

Active caspase-11 pull-down assay. The media of primed BMDMs were replenished with fresh media containing $20 \mu \mathrm{M}$ biotin-VAD-FMK (Enzo) $15 \mathrm{~min}$ before infection. Infected BMDMs were lysed in RIPA buffer $(10 \mathrm{mM}$ Tris- $\mathrm{HCl}$ (pH 7.4), $1 \mathrm{mM}$ EDTA, $150 \mathrm{mM} \mathrm{NaCl}, 1 \%$ Nonidet P-40, $1 \%$ (w/v) sodium deoxycholate and $0.1 \%(\mathrm{w} / \mathrm{v}) \mathrm{SDS}$ ) supplemented with a protease inhibitor cocktail (Roche). Cleared lysates were equalized according to total protein content, incubated overnight with streptavidin-agarose beads (Novex) and thoroughly rinsed with RIPA buffer. Bound proteins were eluted by re-suspension in Laemmli rinsed with RIPA buffer. Bound proteins were eluted by re-suspension in La
sample buffer, boiled for $5 \mathrm{~min}$ and separated by SDS-polyacrylamide gel electrophoresis. 
Statistical analysis. The data were plotted and analysed using GraphPad Prism 5.0 software. The statistical significance was calculated using Student's $t$-test or analysis of variance (ANOVA). Differences were considered statistically significan when the $P$ value was $<0.05$.

\section{References}

. Janeway, Jr C. A. Approaching the asymptote? Evolution and revolution in immunology. Cold Spring Harb. Symp. Quant. Biol. 54(Pt 1): 1-13 (1989).

2. Mariathasan, S. \& Monack, D. M. Inflammasome adaptors and sensors: intracellular regulators of infection and inflammation. Nat. Rev. Immunol. 7, 31-40 (2007).

3. Martinon, F., Burns, K. \& Tschopp, J. The inflammasome: a molecular platform triggering activation of inflammatory caspases and processing of proIL-beta. Mol. Cell 10, 417-426 (2002)

4. Miao, E. A. et al. Cytoplasmic flagellin activates caspase-1 and secretion of interleukin lbeta via Ipaf. Nat. Immunol. 7, 569-575 (2006).

5. Miao, E. A., Ernst, R. K., Dors, M., Mao, D. P. \& Aderem, A. Pseudomonas aeruginosa activates caspase 1 through Ipaf. Proc. Natl Acad. Sci. USA 105, 2562-2567 (2008).

6. Miao, E. A. et al. Innate immune detection of the type III secretion apparatus through the NLRC4 inflammasome. Proc. Natl Acad. Sci. USA 107, 3076-3080 (2010)

7. Kofoed, E. M. \& Vance, R. E. Innate immune recognition of bacterial ligands by NAIPs determines inflammasome specificity. Nature 477, 592-595 (2011)

8. Franchi, L. et al. Critical role for Ipaf in Pseudomonas aeruginosa-induced caspase-1 activation. Eur. J. Immunol. 37, 3030-3039 (2007).

9. Amer, A. et al. Regulation of Legionella phagosome maturation and infection through flagellin and host Ipaf. J. Biol. Chem. 281, 35217-35223 (2006).

10. Ren, T., Zamboni, D. S., Roy, C. R., Dietrich, W. F. \& Vance, R. E. Flagellin-deficient Legionella mutants evade caspase-1- and Naip5-mediated macrophage immunity. PLoS Pathogens 2, el8 (2006).

11. Zamboni, D. S. et al. The Bircle cytosolic pattern-recognition receptor contributes to the detection and control of Legionella pneumophila infection. Nat. Immunol. 7, 318-325 (2006).

12. Aachoui, Y. et al. Caspase-11 protects against bacteria that escape the vacuole. Science 339, 975-978 (2013).

13. Case, C. L. et al. Caspase-11 stimulates rapid flagellin-independent pyroptosis in response to Legionella pneumophila. Proc. Nl Acad. Sci. USA 110, 1851-1856 (2013).

14. Casson, C. N. et al. Caspase-11 activation in response to bacterial secretion systems that access the host cytosol. PLoS Pathogens 9, e1003400 (2013).

15. Gurung, P. et al. Toll or interleukin-1 receptor (TIR) domain-containing adaptor inducing interferon-beta (TRIF)-mediated caspase-11 protease production integrates Toll-like receptor 4 (TLR4) protein- and Nlrp3 inflammasome-mediated host defense against enteropathogens. J. Biol. Chem. 287, 34474-34483 (2012).

16. Hagar, J. A., Powell, D. A., Aachoui, Y., Ernst, R. K. \& Miao, E. A. Cytoplasmic LPS activates caspase-11: implications in TLR4-independent endotoxic shock. Science 341, 1250-1253 (2013).

17. Kayagaki, N. et al. Noncanonical inflammasome activation by intracellular LPS independent of TLR4. Science 341, 1246-1249 (2013).

18. Rathinam, V. A. et al. TRIF licenses caspase-11-dependent NLRP3 inflammasome activation by gram-negative bacteria. Cell 150, 606-619 (2012).

19. Cunha, L. D. \& Zamboni, D. S. Subversion of inflammasome activation and pyroptosis by pathogenic bacteria. Front. Cell. Infect. Microbiol. 3, 76 (2013).

20. Nagai, H. \& Roy, C. R. Show me the substrates: modulation of host cell function by type IV secretion systems. Cell. Microbiol. 5, 373-383 (2003).

21. Galan, J. E. \& Wolf-Watz, H. Protein delivery into eukaryotic cells by type III secretion machines. Nature 444, 567-573 (2006).

22. Baxt, L. A., Garza-Mayers, A. C. \& Goldberg, M. B. Bacterial subversion of host innate immune pathways. Science 340, 697-701 (2013)

23. Jorgensen, I. et al. The Chlamydia protease CPAF regulates host and bacteria proteins to maintain pathogen vacuole integrity and promote virulence. Cell Host Microbe 10, 21-32 (2011)

24. Danelishvili, L., Everman, J. L., McNamara, M. J. \& Bermudez, L. E. Inhibition of the plasma-membrane-associated serine protease cathepsin G by Mycobacterium tuberculosis Rv3364c suppresses caspase-1 and pyroptosis in macrophages. Front. Microbiol. 2, 281 (2011).

25. Shah, S. et al. Cutting edge: Mycobacterium tuberculosis but not nonvirulent mycobacteria inhibits IFN-beta and AIM2 inflammasome-dependent IL-1beta production via its ESX-1 secretion system. J. Immunol. 191, 3514-3518 (2013).

26. Raoult, D., Marrie, T. \& Mege, J. Natural history and pathophysiology of $\mathrm{Q}$ fever. Lancet Infect. Dis. 5, 219-226 (2005).

27. van Schaik, E. J., Chen, C., Mertens, K., Weber, M. M. \& Samuel, J. E. Molecular pathogenesis of the obligate intracellular bacterium Coxiella burnetii. Nat. Rev. Microbiol. 11, 561-573 (2013).
28. Campoy, E. M., Zoppino, F. C. \& Colombo, M. I. The early secretory pathway contributes to the growth of the Coxiella-replicative niche. Infect. Immun. 79, 402-413 (2011).

29. Klingenbeck, L., Eckart, R. A., Berens, C. \& Luhrmann, A. The Coxiella burnetii type IV secretion system substrate CaeB inhibits intrinsic apoptosis at the mitochondrial level. Cell. Microbiol. 15, 675-687 (2012).

30. Larson, C. L., Beare, P. A., Howe, D. \& Heinzen, R. A. Coxiella burnetii effector protein subverts clathrin-mediated vesicular trafficking for pathogen vacuole biogenesis. Proc. Natl Acad. Sci. USA 110, E4770-E4779 (2013).

31. Luhrmann, A., Nogueira, C. V., Carey, K. L. \& Roy, C. R. Inhibition of pathogen-induced apoptosis by a Coxiella burnetii type IV effector protein. Proc. Natl Acad. Sci. USA 107, 18997-19001 (2010).

32. Luhrmann, A. \& Roy, C. R. Coxiella burnetii inhibits activation of host cell apoptosis through a mechanism that involves preventing cytochrome $\mathrm{c}$ release from mitochondria. Infect. Immun. 75, 5282-5289 (2007).

33. McDonough, J. A. et al. Host pathways important for Coxiella burnetii infection revealed by genome-wide RNA interference screening. MBio 4, e00606-e00612 (2013).

34. Voth, D. E. \& Heinzen, R. A. Sustained activation of Akt and Erk1/2 is required for Coxiella burnetii antiapoptotic activity. Infect. Immun. 77, 205-213 (2009).

35. Voth, D. E., Howe, D. \& Heinzen, R. A. Coxiella burnetii inhibits apoptosis in human THP-1 cells and monkey primary alveolar macrophages. Infect. Immun. 75, 4263-4271 (2007).

36. Vazquez, C. L. \& Colombo, M. I. Coxiella burnetii modulates Beclin 1 and $\mathrm{Bcl}-2$, preventing host cell apoptosis to generate a persistent bacterial infection. Cell Death Differ. 17, 421-438 (2010).

37. Shannon, J. G., Howe, D. \& Heinzen, R. A. Virulent Coxiella burnetii does not activate human dendritic cells: role of lipopolysaccharide as a shielding molecule. Proc. Natl Acad. Sci. USA 102, 8722-8727 (2005).

38. Zamboni, D. S. Genetic control of natural resistance of mouse macrophages to Coxiella burnetii infection in vitro: macrophages from restrictive strains control parasitophorous vacuole maturation. Infect. Immun. 72, 2395-2399 (2004).

(2004).
9. Zamboni, D. S. et al. Stimulation of toll-like receptor 2 by Coxiella burnetii is required for macrophage production of pro-inflammatory cytokines and resistance to infection. J. Biol. Chem. 279, 54405-54415 (2004).

40. Seshadri, R. et al. Complete genome sequence of the Q-fever pathogen Coxiella burnetii. Proc. Natl Acad. Sci. USA 100, 5455-5460 (2003).

41. Zamboni, D. S., McGrath, S., Rabinovitch, M. \& Roy, C. R. Coxiella burnetii express type IV secretion system proteins that function similarly to components of the Legionella pneumophila Dot/Icm system. Mol. Microbiol. 49, 965-976 (2003).

42. Zusman, T., Yerushalmi, G. \& Segal, G. Functional similarities between the $\mathrm{icm} /$ dot pathogenesis systems of Coxiella burnetii and Legionella pneumophila. Infect. Immun. 71, 3714-3723 (2003).

43. Beare, P. A. et al. Comparative genomics reveal extensive transposon-mediated genomic plasticity and diversity among potential effector proteins within the genus Coxiella. Infect. Immun. 77, 642-656 (2009).

44. Carey, K. L., Newton, H. J., Luhrmann, A. \& Roy, C. R. The Coxiella burnetii Dot/Icm system delivers a unique repertoire of type IV effectors into host cells and is required for intracellular replication. PLoS Pathogens 7, e1002056 (2011).

45. Chen, C. et al. Large-scale identification and translocation of type IV secretion substrates by Coxiella burnetii. Proc. Natl Acad. Sci. USA 107, 21755-21760 (2010).

46. Voth, D. E. et al. The Coxiella burnetii cryptic plasmid is enriched in genes encoding type IV secretion system substrates. J. Bacteriol. 193, 1493-1503 (2011).

47. Voth, D. E. et al. The Coxiella burnetii ankyrin repeat domain-containing protein family is heterogeneous, with C-terminal truncations that influence Dot/Icm-mediated secretion. J. Bacteriol. 191, 4232-4242 (2009).

48. Weber, M. M. et al. Identification of Coxiella burnetii type IV secretion substrates required for intracellular replication and Coxiella-containing vacuole formation. J. Bacteriol. 195, 3914-3924 (2013).

49. Lifshitz, Z. et al. Computational modeling and experimental validation of the Legionella and Coxiella virulence-related type-IVB secretion signal. Proc. Natl Acad. Sci. USA 110, E707-E715 (2013).

50. Pan, X., Luhrmann, A., Satoh, A., Laskowski-Arce, M. A. \& Roy, C. R. Ankyrin repeat proteins comprise a diverse family of bacterial type IV effectors. Science 320, 1651-1654 (2008)

51. Sauer, J. D. et al. Specificity of Legionella pneumophila and Coxiella burnetii vacuoles and versatility of Legionella pneumophila revealed by coinfection. Infect. Immun. 73, 4494-4504 (2005).

52. Case, C. L., Shin, S. \& Roy, C. R. Asc and Ipaf Inflammasomes direct distinct pathways for caspase-1 activation in response to Legionella pneumophila. Infect. Immun. 77, 1981-1991 (2009).

53. Kayagaki, N. et al. Non-canonical inflammasome activation targets caspase-11. Nature 479, 117-121 (2011). 
54. Cerqueira, D. M., Pereira, M. S., Silva, A. L., Cunha, L. D. \& Zamboni, D. S. Caspase-1 but not caspase-11 is required for NLRC4-mediated pyroptosis an restriction of infection by flagellated Legionella species in mouse macrophages and in vivo. J. Immunol. 195, 2303-2311 (2015).

55. Newton, H. J., McDonough, J. A. \& Roy, C. R. Effector protein translocation by the Coxiella burnetii Dot/Icm type IV secretion system requires endocytic maturation of the pathogen-occupied vacuole. PLoS ONE 8, e54566 (2013)

56. Molofsky, A. B. et al. Cytosolic recognition of flagellin by mouse macrophages restricts Legionella pneumophila infection. J. Exp. Med. 203, 1093-1104 (2006).

57. Silveira, T. N. \& Zamboni, D. S. Pore formation triggered by Legionella spp. is an Nlrc4 inflammasome-dependent host cell response that precedes pyroptosis. Infect. Immun. 78, 1403-1413 (2010).

58. Brooke, R. J., Kretzschmar, M. E., Mutters, N. T. \& Teunis, P. F. Human dose response relation for airborne exposure to Coxiella burnetii. BMC Infect. Dis. 13, 488 (2013).

59. Beare, P. A. et al. Dot/Icm type IVB secretion system requirements for Coxiella burnetii growth in human macrophages. MBio 2, e00175-e00211 (2011).

60. Broz, P. et al. Caspase-11 increases susceptibility to Salmonella infection in the absence of caspase-1. Nature 490, 288-291 (2012).

61. Graham, J. G. et al. Virulent Coxiella burnetii pathotypes productively infect primary human alveolar macrophages. Cell. Microbiol. 15, 1012-1025 (2013).

62. Kobayashi, T. et al. The Shigella OspC3 effector inhibits caspase-4, antagonizes inflammatory cell death, and promotes epithelial infection. Cell Host Microbe 13, 570-583 (2013).

63. Zamboni, D. S., Mortara, R. A. \& Rabinovitch, M. Infection of Vero cells with Coxiella burnetii phase II: relative intracellular bacterial load and distribution estimated by confocal laser scanning microscopy and morphometry. J. Microbiol. Methods 43, 223-232 (2001).

64. Berger, K. H. \& Isberg, R. R. Two distinct defects in intracellular growth complemented by a single genetic locus in Legionella pneumophila. Mol. Microbiol. 7, 7-19 (1993).

65. Sadosky, A. B., Wiater, L. A. \& Shuman, H. A. Identification of Legionelle pneumophila genes required for growth within and killing of human macrophages. Infect. Immun. 61, 5361-5373 (1993).

66. Beare, P. A. \& Heinzen, R. A. Gene inactivation in Coxiella burnetii. Methods Mol. Biol. 1197, 329-345 (2014).

67. Brennan, R. E. \& Samuel, J. E. Evaluation of Coxiella burnetii antibiotic susceptibilities by real-time PCR assay. J. Clin. Microbiol. 41, 1869-1874 (2003).

68. Marim, F. M., Silveira, T. N., Lima, Jr D. S. \& Zamboni, D. S. A method for generation of bone marrow-derived macrophages from cryopreserved mouse bone marrow cells. PLoS ONE 5, el5263 (2010).

69. Naviaux, R. K., Costanzi, E., Haas, M. \& Verma, I. M. The pCL vector system: rapid production of helper-free, high-titer, recombinant retroviruses. J. Virol. 70, 5701-5705 (1996)
70. Beare, P. A., Howe, D., Cockrell, D. C. \& Heinzen, R. A. Efficient method of cloning the obligate intracellular bacterium Coxiella burnetii. Appl. Environ. Microbiol. 73, 4048-4054 (2007).

\section{Acknowledgements}

This paper is dedicated to Dr Michel Rabinovitch, whose passion for biology and scientific investigation co-infects his students forever. We thank Maira Nakamura for her technical assistance, to Richard Flavell (Yale, USA) for providing us with $\mathrm{Nlrc}^{-}{ }^{-1}$

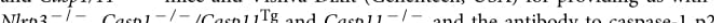

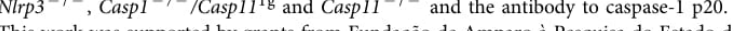
This work was supported by grants from Fundação de Amparo à Pesquisa do Estado de São Paulo (FAPESP, grants 2013/08216-2, 2014/50268-2 and 2014/04684-4), Conselho Nacional do Desenvolvimento Cientifico e Tecnológico (CNPq and INCTV/CNPq), Coordenação de Aperfeiçoamento de Pessoal de Nível Superior (CAPES), Núcleo de Apoio à Pesquisa em Doenças Inflamatórias (NAPDIN, grant 11.1.21625.01.0) and the PEW Program in Biomedical Sciences. LD.C and JM.R are supported by fellowships from FAPESP. LM and T.D.F. are visiting professor from Science Without Borders Program (CNPq, grant 401577/2014-7). D.S.Z. is a research fellow from CNPq, Brazil.

\section{Author contributions}

L.D.C., T.D.F., H.J.N., C.R.R. and D.S.Z. designed the experiments; L.D.C., J.M.R., T.D.F., L.M.M., C.A.K., J.H.M. and H.J.N. performed the experiments; L.D.C., J.M.R., T.D.F. and D.S.Z. processed and analysed the data; L.D.C. and D.S.Z. wrote the manuscript; and all authors commented on the manuscript.

\section{Additional information}

Supplementary Information accompanies this paper at http://www.nature.com/ naturecommunications

Competing financial interests: The authors declare no competing financial interests.

Reprints and permission information is available online at http://npg.nature.com/ reprintsandpermissions/

How to cite this article: Cunha, L. D. et al. Inhibition of inflammasome activation by Coxiella burnetii type IV secretion system effector IcaA. Nat. Commun. 6:10205 doi: $10.1038 /$ ncomms10205 (2015).

This work is licensed under a Creative Commons Attribution 4.0 International License. The images or other third party material in this article are included in the article's Creative Commons license, unless indicated otherwise in the credit line; if the material is not included under the Creative Commons license, users will need to obtain permission from the license holder to reproduce the material. To view a copy of this license, visit http://creativecommons.org/licenses/by/4.0/ 


\section{Supplementary Information}
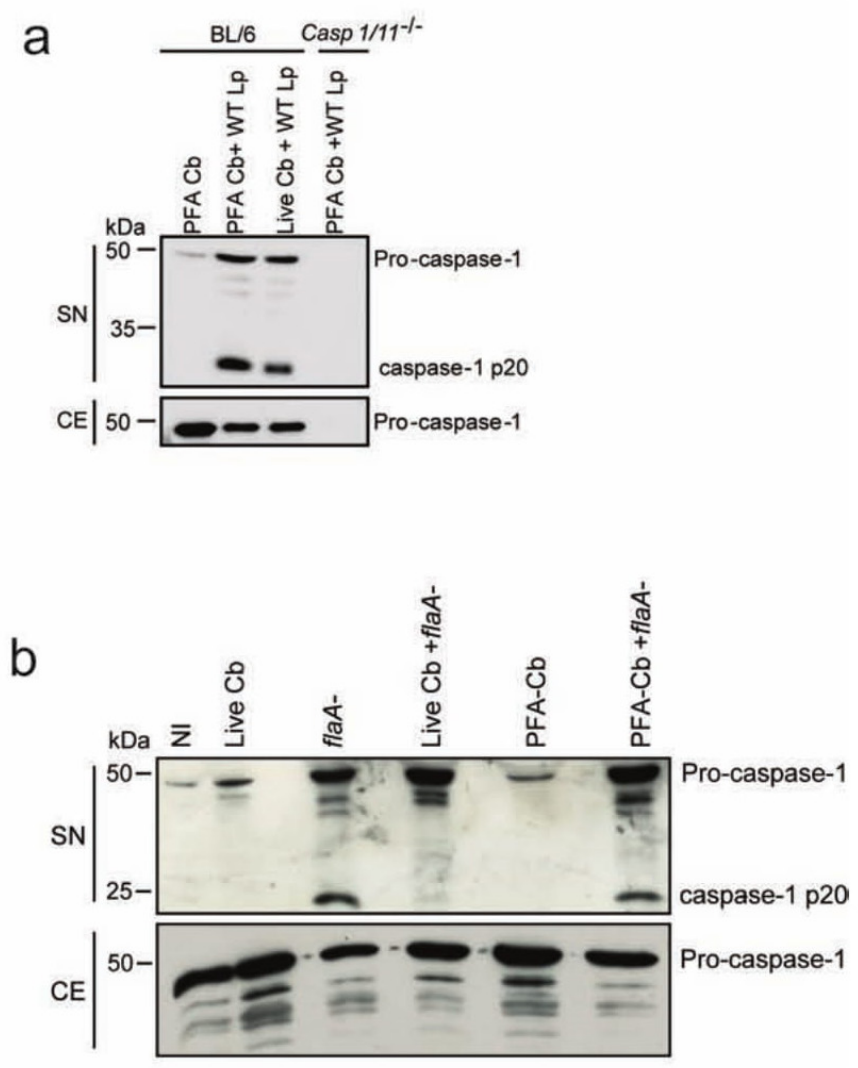

Supplementary Figure 1. Viable $C$. burnetii is required for inhibition caspase-1 activation induced by L. pneumophila. Bone marrow-derived macrophages (BMDM) were left uninfected (NI) or were infected with PFA-fixed (PFA Cb) or live C. burnetii (Live $\mathrm{Cb}$ ) at MOI 30 for $24 \mathrm{~h}$ and further infected with wild-type L. pneumophila (WT Lp, MOI 10) or flaA- mutant (flaA-) for 9 h. Co-infected BMDM are indicated ( $\mathrm{Cb}+$ WT Lp or $\mathrm{Cb}+\mathrm{flaA}^{-}$). (a) Immunoblot showing levels of processed $\mathrm{p} 20$ subunit of caspase- 1 (caspase-1 p20) and unprocessed caspase-1 (pro-caspase-1), as determined in supernatant (SN) and cell extract (CE). (b) Similar in (a) for BL/6 BMDM. 


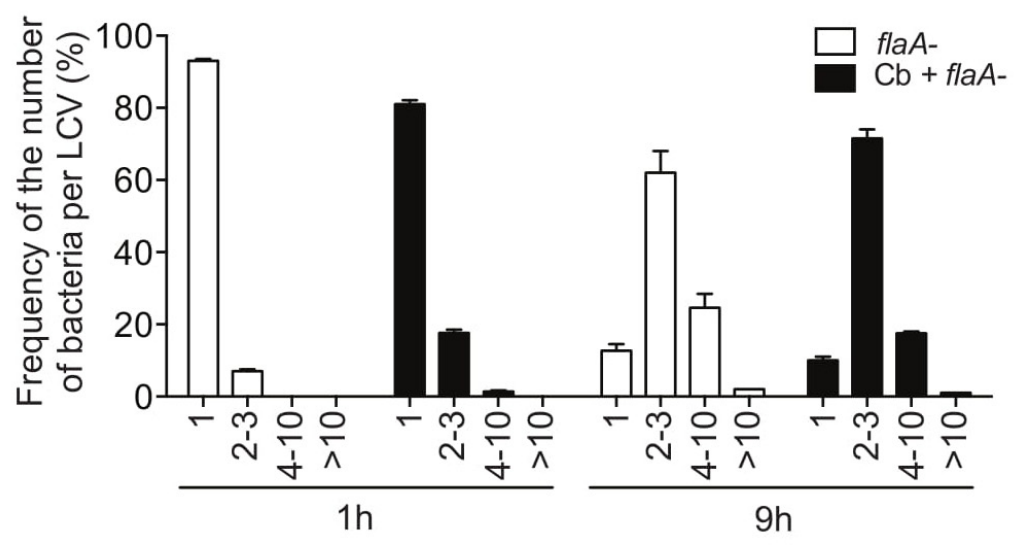

Supplementary Figure 2. Co-infection with $C$. burnetii does not interfere with flaA- $L$.

pneumophila replication in BMDM. Bone marrow-derived macrophages (BMDM) from C57BL/6 mice were left uninfected or were infected with $C$. burnetii at MOI 30 for $24 \mathrm{~h}$ and further infected with flaA- L. pneumophila strain Lp01 (flaA-, MOI 10) for 9 h. Co-infected BMDM are indicated (Cb + fla $A$-). An estimation of the frequency of bacteria per Legionella-containing vacuole (LCV), as assessed by counting on the fluorescence microscopy, is shown.

a

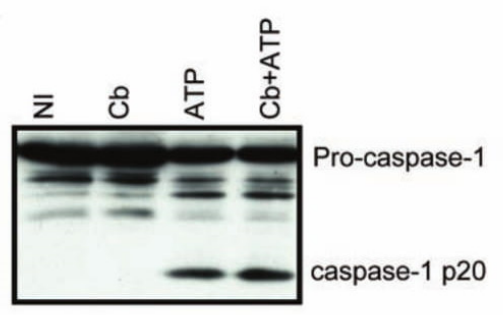

C
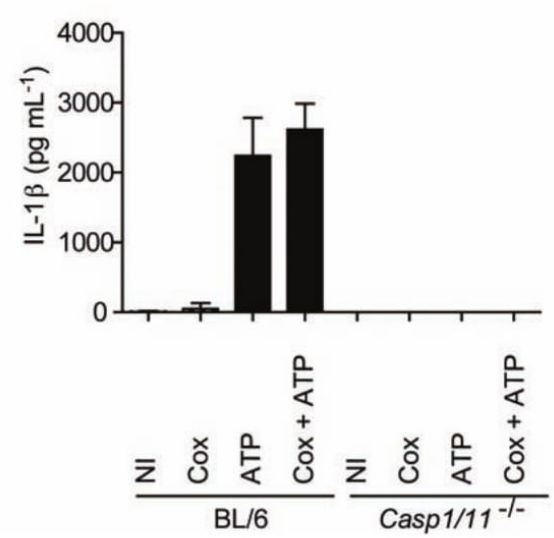

b

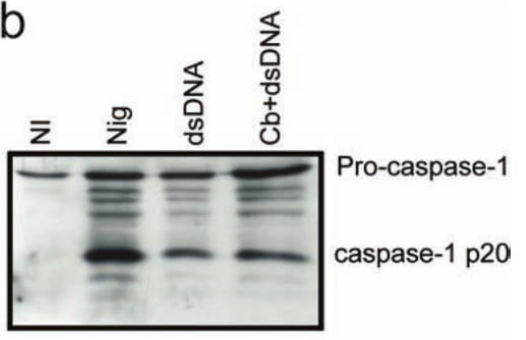

d

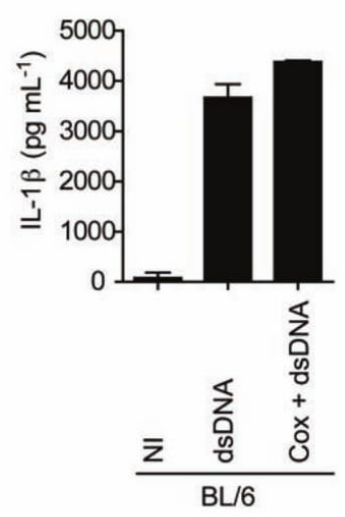

Supplementary Figure 3. C. burnetii does not interfere with ATP-mediated activation of the canonical NLRP3 inflammasome or with dsDNA-mediated activation of the AIM2

inflammasome. Bone marrow-derived macrophages (BMDM) were left uninfected (NI) or were infected with $C$. burnetii (Cb, MOI 30) for $24 \mathrm{~h}$ and further stimulated with LPS $\left(1 \mu \mathrm{g} \mathrm{ml}^{-1}\right)$ for $4 \mathrm{~h}$. The cells were then treated with either ATP $(5 \mathrm{mM})$ for 20 min or nigericin $(20 \mathrm{mM})$ for 40 min or were transfected with $1 \mu \mathrm{g}$ of dsDNA for $6 \mathrm{~h}$. (a, b) Immunoblot showing levels of processed p20 subunit of caspase-1 (caspase-1 p20) and unprocessed caspase-1 (pro-caspase-1), as determined in supernatant (SN) and cell extract (CE) of BL/6 BMDM. (c, d) IL-1 $\beta$ secretion in the supernatant was estimated by ELISA. 
a
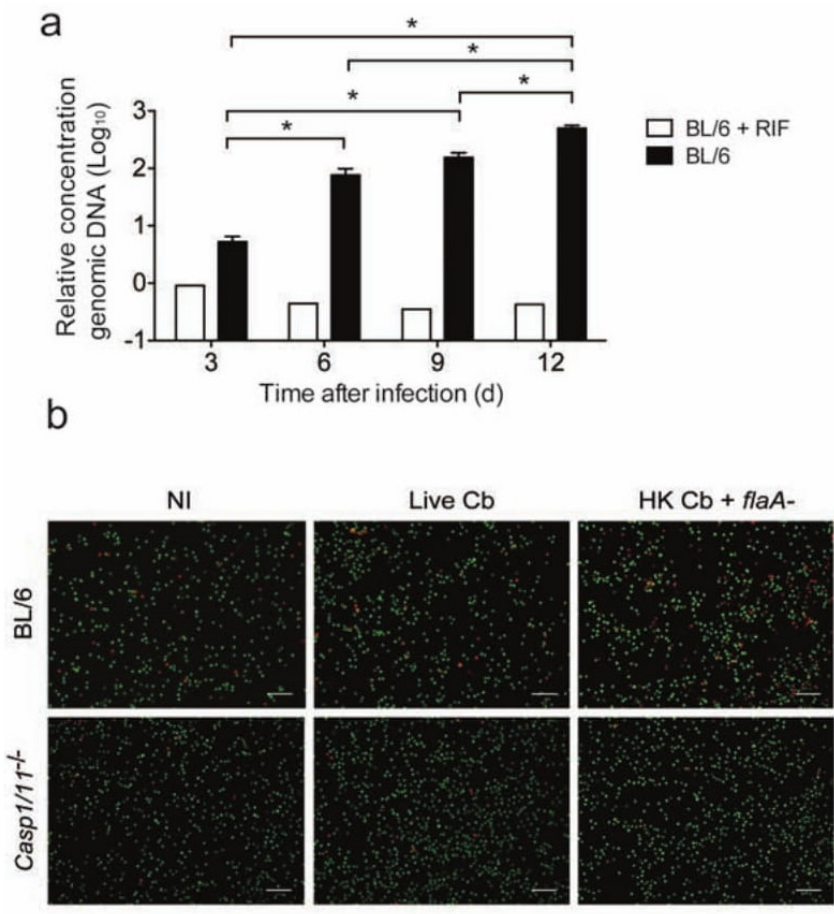

Live $\mathrm{Cb}+$ flaA-

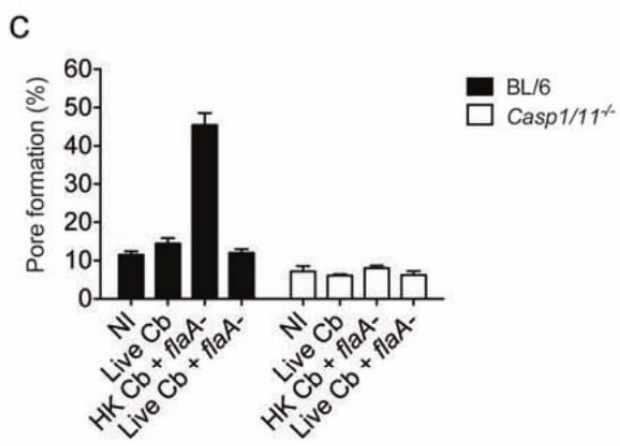

Supplementary Figure 4. C. burnetii inhibits pore formation in response to flaA- $L$.

pneumophila in alveolar macrophages. (a) Alveolar macrophages (AM) from C57BL/6 mice were infected with $C$. burnetii (MOI 3), and bacterial growth was assessed by qPCR. Relative bacterial replication was calculated as $\log \left(Y_{x=n}\right)-\log \left(Y_{x=0}\right)$. Control AM were treated with bacterial translation inhibitor rifampicin (RIF, $20 \mathrm{mg} \mathrm{mL}^{-1}$ ). Data are expressed as the average \pm SEM of triplicate wells and significance was calculated with ANOVA. ${ }^{*}, P<0.05$. (b,c) AM were left uninfected (NI) or were infected with heat-killed (HK Cb) or live $C$. burnetii (Live $\mathrm{Cb}$ ) at MOI 30 for $6 \mathrm{~h}$ and further infected with flaA- L. pneumophila (flaA-, MOI 10) for $3 \mathrm{~h}$. (b) Fluorescence micrographs revealing cell permeability, as assessed by the quantification of EtBr influx (red dots) in acridine orange (green) stained AM. Scale bar corresponds to $75 \mu \mathrm{m}$. (c) Quantification of the experiment shown in (b). 

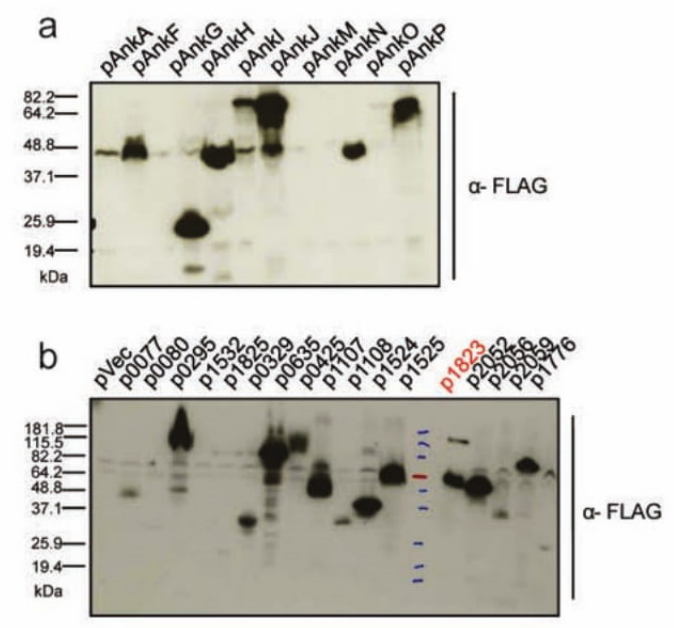

C

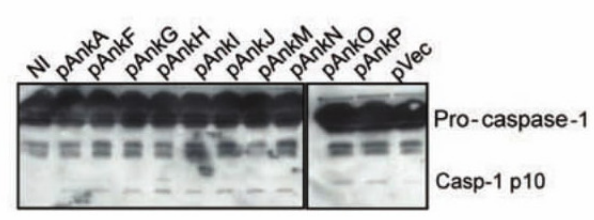

d

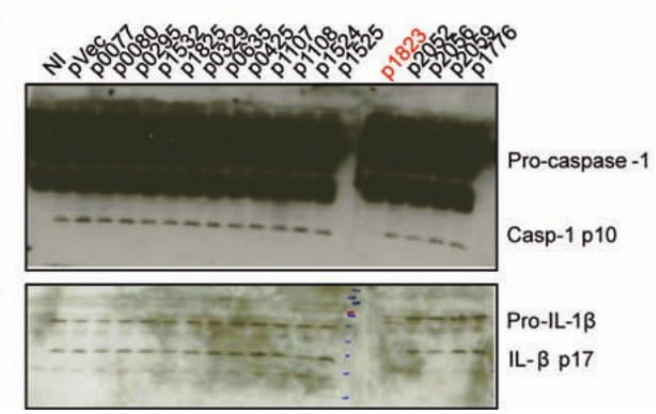

Supplementary Figure 5. Identification of CBU1823 (IcaA) as an effector protein that inhibits a flagellin-independent pathway for caspase-1 activation induced by $L$. pneumophila. Bone marrow-derived macrophages (BMDM) from C57BL/6 mice were infected with flaA- L. pneumophila expressing each indicated effector (indicated is the CBU number or the protein name) or an empty vector ( $\mathrm{pVec}$ ) for $9 \mathrm{~h}$ in the presence of $1 \mathrm{mM} \mathrm{IPTG.} \mathrm{(a,} \mathrm{b)} \mathrm{Mutants} \mathrm{were} \mathrm{grown} \mathrm{in} \mathrm{CYE} \mathrm{agar} \mathrm{plates} \mathrm{for}$ two days, and effector expression was assessed by immunoblot for the Flag epitope tag (expression of N-terminal Flag fusions). (c, d) Immunoblot showing levels of processed p10 subunit of caspase-1 (caspase-1 p10) and unprocessed caspase-1 (pro-caspase-1) in supernatant. (e) Immunoblot showing levels of $\mathrm{p} 17$ subunit of mature IL-1 $\beta$ (IL-1 $\beta$ p17) and pro-IL-1 $\beta$ in supernatant fraction. CBU1823 (IcaA) is highlighted in red. 


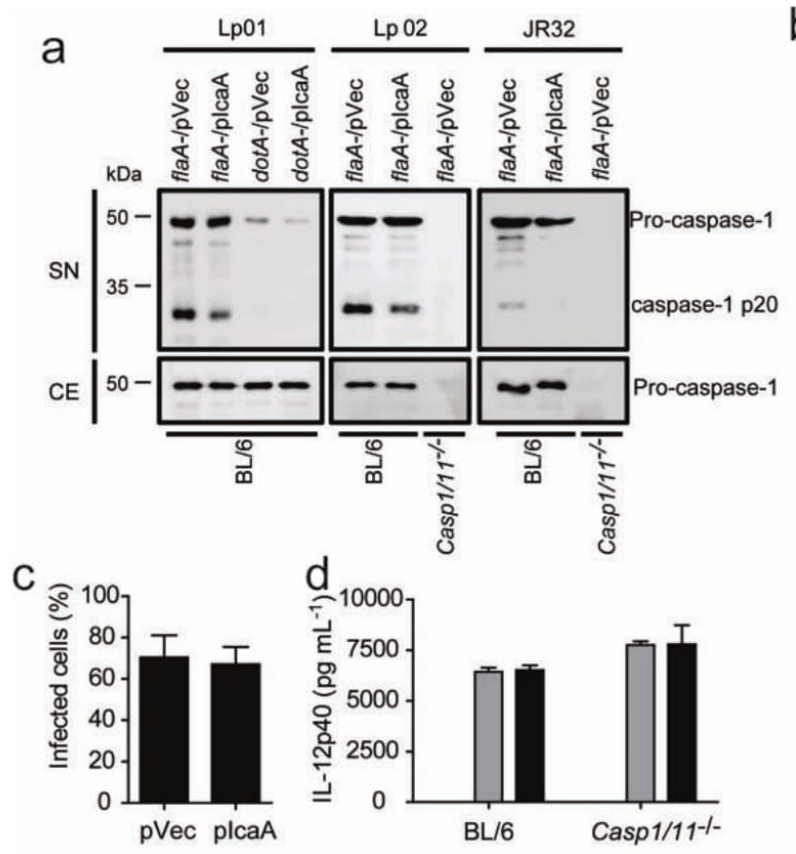

b

e

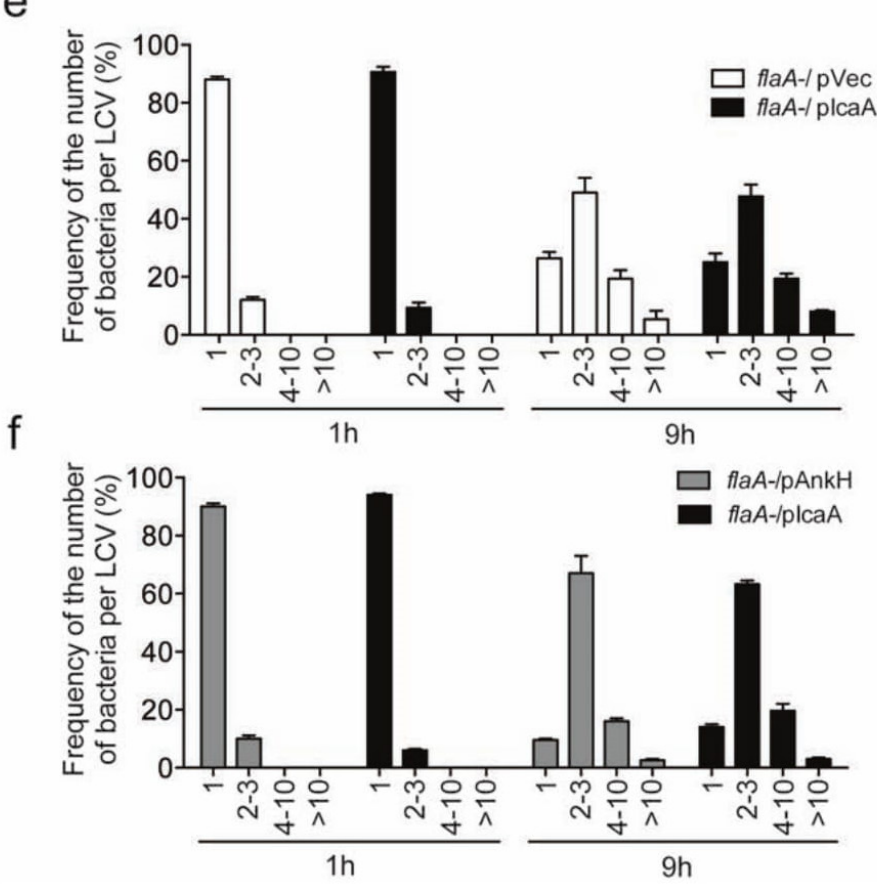

Supplementary Figure 6. Expression of IcaA by L. pneumophila interferes with caspase-1 activation but does not influence the replication in axenic media, macrophage infection or the induction of IL-12p40. fla $A^{-}$or dot $A^{-}$mutants from three different $L$. pneumophila strains: Lp01, thymidine auxotroph Lp02 and JR32, transformed with the empty vector (pVec), pSN85 encoding IcaA (pIcaA) or pSN85 encoding AnkH (pAnkH) were evaluated. (a) Immunoblot showing levels of processed p20 subunit of caspase-1 (caspase-1 p20) and unprocessed caspase-1 (pro-Casp-1), as determined in supernatant (SN) and cell extract (CE) of bone marrow-derived macrophages (BMDM) infected for $9 \mathrm{~h}$. (b) Replication of fla $\mathrm{A}^{-} / \mathrm{pVec}$ and flaA-/pIcaA (strain Lp01) in AYE broth was assessed by optic density (OD) at $600 \mathrm{~nm}$. (c) BL/6 BMDM were infected with fla $A^{-} / \mathrm{pVec}$ and flaA /pIcaA (strain Lp01) for $1 \mathrm{~h}$, and bacterial internalization was assessed by fluorescence microscopy using anti-L. pneumophila. (d) IL-12p40 secretion in the supernatant of BMDM infected for $9 \mathrm{~h}$ with $\mathrm{flaA}^{-} / \mathrm{pVec}$ and $\mathrm{flaA} / \mathrm{pIcaA}$ (strain Lp02), as estimated by ELISA. (e, f) Estimation of the frequency of bacteria per Legionella-containing vacuole (LCV) of BMDM infected with $f l a A^{-} / \mathrm{pVec}$ and $f l a A^{-} / \mathrm{pIcaA}$ and flaA $^{-} / \mathrm{pAnkH}$ (strain Lp01), as assessed by counting on fluorescence microscopy. (g) IL-1 $\beta$ secretion in the supernatant of BMDM infected for $9 \mathrm{~h}$ with $f l a A^{-} / \mathrm{pVec}$ and fla $A^{-} / \mathrm{pIcaA}$ (strain Lp02), as estimated by ELISA. Data are expressed as the average \pm SEM of triplicate wells and significance was calculated with ANOVA. ${ }^{*}, P<0.05$. 
a WT Lp

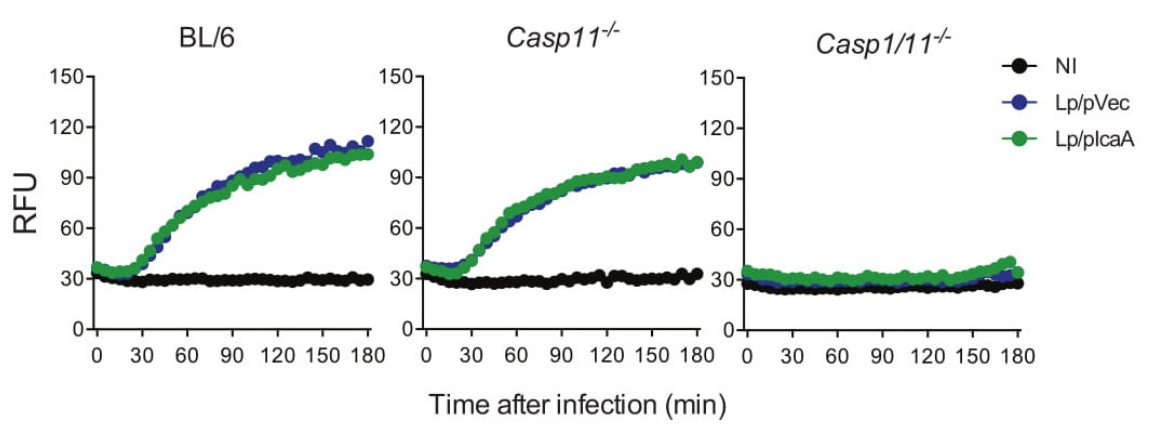

b flaA- Lp

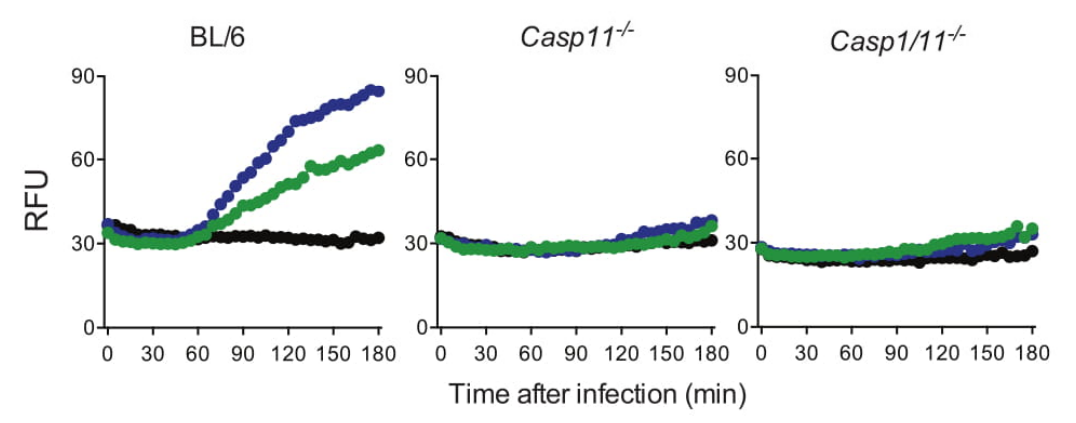

Supplementary Figure 7. IcaA inhibits caspase-11-dependent pore formation in response to flaA $\boldsymbol{A}^{-}$. pneumophila. Bone marrow-derived macrophages (BMDM) from C57BL/6 or isogenic mice deficient in caspase- 11 or caspase-1/11 were primed with LPS $\left(0.5 \mathrm{mg} \mathrm{mL}^{-1}\right)$ for $3 \mathrm{~h}$. Cells were left uninfected (NI) or were infected with wild-type (a) or flaA - L. pneumophila (b) transformed with either an empty vector $(\mathrm{Lp} / \mathrm{pVec})$ or a vector encoding IcaA (Lp/pIcaA) at MOI 10 . Pore formation was assessed fluorometrically in real time by the uptake of propidium iodide (RFUs, relative fluorescence units).

a

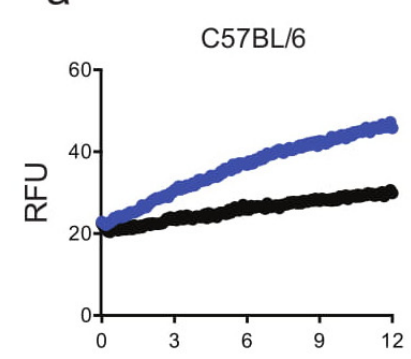

b

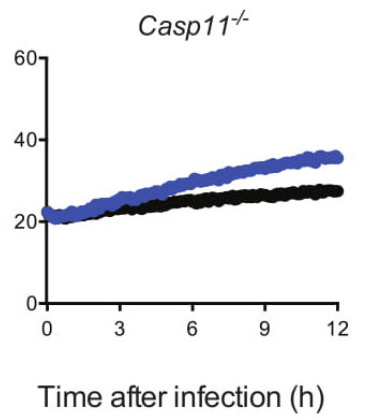

C

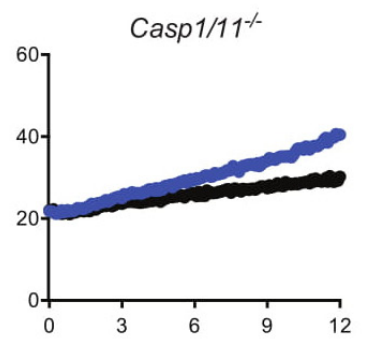

Supplementary Figure 8. C. burnetii LPS induces pore formation when transfected in macrophages. Bone marrow-derived macrophages (BMDM) generated from C57BL/6 (a), Casp 11\% (b) or Casp1/11\% (c) mice were primed with poly I:C $\left(5 \mu \mathrm{g} \mathrm{ml}^{-1}\right)$ for $4 \mathrm{~h}$. Cells were transfected with $1 \mu \mathrm{g} \mathrm{ml}^{-1}$ C. burnetii LPS (blue) or with MOCK (black) for up to $12 \mathrm{hrs}$. Pore formation was assessed fluorometrically in real time by the uptake of propidium iodide (RFUs, relative fluorescence units). 


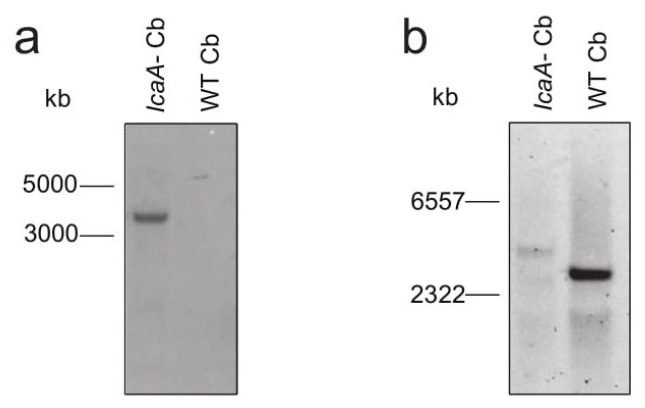

Supplementary Figure 9. Validation of the icaA mutant C. burnetii. CBU_1823 (icaA-) knockout was confirmed by southern hybridization using probes to icaA and the kanamycin resistance cassette. (a) Southern blot with probe against kanamycin resistance cassette. (b) Southern blot with probe against icaA. 

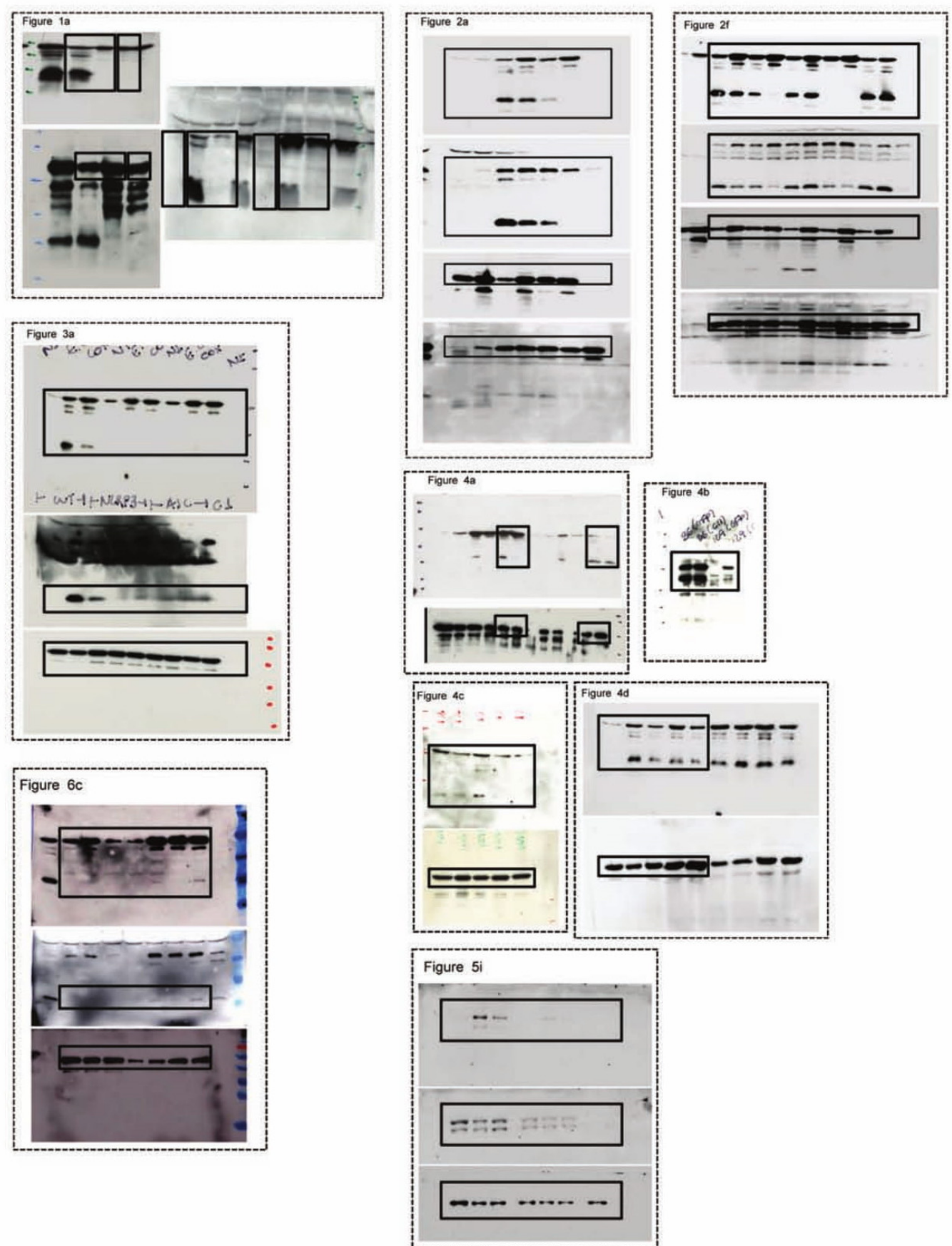

Supplementary Figure 10. Full immunoblots of main figures presented in this study. 
Suplemmentary Table1. List of the primers used in this study

\begin{tabular}{|c|c|c|}
\hline Primer & Sequence 5' to 3' & Purpose \\
\hline AnkA F & AAggatccTCTTGCTTAGCTTAATGG & pSN85 \\
\hline AnkA R & AAgcatgcTTAAAACAGTCCGGGGCC & pSN85 \\
\hline AnkB F & AAtctagaGTATGTTTAACCAATTGGA & pSN85 \\
\hline AnkB R & GGgcatgcTTACATGTGCTTACCCGG & pSN85 \\
\hline AnkF F & AAggatccTCATGAGACAGCGTGAAA & pSN85 \\
\hline AnkF R & AAgcatgcCTACCGCTGGAAGCCGC & pSN85 \\
\hline AnkG F & AAggatccTCATGAGTAGACGTGAGA & pSN85 \\
\hline AnkG R & AAgcatgcTCACCGAGGACTAGACAG & pSN85 \\
\hline AnkH F & AAggatccTCTTGTCAGAATTAGGAG & pSN85 \\
\hline AnkH R & AAgcatgcTTAGATTAACGTGCGCGT & pSN85 \\
\hline Ankl F & AAggatccTCATGAGAGAATCATCAG & pSN85 \\
\hline Ankl R & AAgcatgcСТАAАTTCСАAАAGAACC & pSN85 \\
\hline AnkJ F & AAggatccTCATGGCGAAATTTACTA & pSN85 \\
\hline AnkJ R & AAgcatgcTTACGCAGCGCGCATGGT & pSN85 \\
\hline AnkN F & AAggatccTCTTGCGAGAGCTTATGA & pSN85 \\
\hline AnkN R & AAgcatgcCTATAGACCGTATTGCTG & pSN85 \\
\hline AnkO F & AAggatccTCATGGAAATAATTTCCTT & pSN85 \\
\hline AnkO R & AAgcatgcTTAATAACGATTTTTTGTT & pSN85 \\
\hline AnkP F & AAggatccTCGTGGGACAAAATACAA & pSN85 \\
\hline AnkP R & AAgcatgcCTTAAGCTAAGCAAGGGG & pSN85 \\
\hline $\begin{array}{l}\text { CBU1823_1 } \\
\text { FOR }\end{array}$ & GACggatccATTCCTAAGGTGGATATGTGGGC & pJC1823-FL \\
\hline $\begin{array}{l}\text { CBU1823_1 } \\
\text { REV }\end{array}$ & GACgtcgacCGAGTTGGTTTTTCATTGCCAAGG & pJC1823-FL \\
\hline $\begin{array}{l}\text { CBU1823_2 } \\
\text { FOR }\end{array}$ & $\begin{array}{l}\text { GATgtcgacgcggccgcgcatgcATTTCCCTCCGCAA } \\
\text { TAGCTTA }\end{array}$ & pJC1823-KO \\
\hline $\begin{array}{l}\text { CBU1823_2 } \\
\text { REV }\end{array}$ & $\begin{array}{l}\text { GATgcatgcgcggccgcCTTGCCTTTTACССССТC } \\
\text { GT }\end{array}$ & pJC1823-KO \\
\hline Kan FOR & GACgcggccgcAGCTTATGGCTTCGTTTCGCAG & pJC1823-KO \\
\hline Kan REV & $\begin{array}{l}\text { GACgcggccgcTCAGAAGAACTCGTCAAGAAGG } \\
\text { CG }\end{array}$ & pJC1823-KO \\
\hline $\begin{array}{l}\text { CBU1823_SH } \\
\text { F }\end{array}$ & CCATTCAAGAGAGTTCATGTATGCCATCA & $\begin{array}{l}\text { Southern } \\
\text { hybridization }\end{array}$ \\
\hline $\begin{array}{l}\text { CBU1823_SH } \\
\text { R }\end{array}$ & АTCTCATCTCCTTCAGCCTGACTT & $\begin{array}{l}\text { Southern } \\
\text { hybridization }\end{array}$ \\
\hline Kan_SH F & GTGGAGAGGCTATTCGGCTATG & $\begin{array}{l}\text { Southern } \\
\text { hybridization }\end{array}$ \\
\hline Kan_SH R & TTGAGCCTGGCGAACAGTT & $\begin{array}{l}\text { Southern } \\
\text { hybridization }\end{array}$ \\
\hline $\mathrm{Cb} \operatorname{dot} \mathrm{A} F 1$ & GCGCAATACGCTCAATCACA & qPCR \\
\hline Cb dotA R1 & CCATGGCCCCAATTCTCTT & qPCR \\
\hline
\end{tabular}


10.2. Anexo 3 - Artigo publicado (MASCARENHAS, Danielle PA; CERQUEIRA, Daiane M; PEREIRA, Marcelo SF; CASTANHEIRA, Fernanda VS; FERNANDES, Talita D; MANIN, Graziele Z; CUNHA, Larissa D; ZAMBONI, Dario S. Pathogens, 2017)

"Inhibition of caspase- 1 or gasdermin-D enable caspase- 8 activation in the Naip5/NLRC4/ASC inflammasome"

- Publicado em: agosto de 2017 


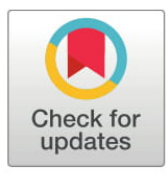

\section{Gopenaccess}

Citation: Mascarenhas DPA, Cerqueira DM, Pereira MSF, Castanheira FVS, Fernandes TD, Manin GZ, et al. (2017) Inhibition of caspase-1 or gasdermin-D enable caspase-8 activation in the Naip5/NLRC4/ ASC inflammasome. PLoS Pathog 13(8): e1006502. https://doi.org/10.1371/journal. ppat. 1006502

Editor: H. Steven Seifert, Northwestern University Feinberg School of Medicine, UNITED STATES

Received: March 9, 2017

Accepted: June 30, 2017

Published: August 3, 2017

Copyright: ๑ 2017 Mascarenhas et al. This is an open access article distributed under the terms of the Creative Commons Attribution License, which permits unrestricted use, distribution, and reproduction in any medium, provided the original author and source are credited.

Data Availability Statement: All relevant data are within the paper and its Supporting Information files.

Funding: This work was supported by grants from Fundação de Amparo à Pesquisa do Estado de São Paulo (FAPESP, grants 2012/09363-6, 2013/ 08216-2 and 2014/04684-4), Conselho Nacional do Desenvolvimento Cientifico e Tecnológico (CNPq) and Coordenação de Aperfeiçoamento de Pessoal de Nivel Superior (CAPES). DSZ is a
RESEARCH ARTICLE

\section{Inhibition of caspase- 1 or gasdermin-D enable caspase- 8 activation in the Naip5/NLRC4/ASC inflammasome}

Danielle P. A. Mascarenhas, Daiane M. Cerqueira, Marcelo S. F. Pereira, Fernanda V. S. Castanheira, Talita D. Fernandes, Graziele Z. Manin, Larissa D. Cunha, Dario S. Zamboni*

Department of Cell Biology, School of Medicine of Ribeirão Preto, University of São Paulo. Ribeirão Preto, Brazil

*dszamboni@fmrp.usp.br

\section{Abstract}

Legionella pneumophila is a Gram-negative, flagellated bacterium that survives in phagocytes and causes Legionnaires' disease. Upon infection of mammalian macrophages, cytosolic flagellin triggers the activation of Naip/NLRC4 inflammasome, which culminates in pyroptosis and restriction of bacterial replication. Although NLRC4 and caspase- 1 participate in the same inflammasome, $\mathrm{NIrC}^{-\%}$ mice and their macrophages are more permissive to $L$. pneumophila replication compared with Casp $1 / 11^{\%}$. This feature supports the existence of a pathway that is NLRC4-dependent and caspase-1/11-independent. Here, we demonstrate that caspase- 8 is recruited to the Naip5/NLRC4/ASC inflammasome in response to flagellin-positive bacteria. Accordingly, caspase-8 is activated in Casp1/11\% macrophages in a process dependent on flagellin, Naip5, NLRC4 and ASC. Silencing caspase-8 in Casp $1 / 11^{-/}$cells culminated in macrophages that were as susceptible as NIrc4 ${ }^{-/}$ for the restriction of $L$. pneumophila replication. Accordingly, macrophages and mice deficient in Asc/Casp $1 / 11^{-/}$were more susceptible than Casp $1 / 11^{-/}$and as susceptible as $\mathrm{NIrC}^{-/ /}$for the restriction of infection. Mechanistically, we found that caspase-8 activation triggers gasdermin-D-independent pore formation and cell death. Interestingly, caspase-8 is recruited to the Naip5/NLRC4/ASC inflammasome in wild-type macrophages, but it is only activated when caspase- 1 or gasdermin- $D$ is inhibited. Our data suggest that caspase- 8 activation in the Naip5/NLRC4/ASC inflammasome enable induction of cell death when caspase- 1 or gasdermin- $D$ is suppressed.
Author summary
Legionella pneumophila is the causative agent of Legionnaires' disease, an atypical pneu- mophila that affects people worldwide. Besides the clinical importance, $L$. pneumophila is a very useful model of pathogenic bacteria for investigation of the interactions of innate immune cells with bacterial pathogens. Studies using L. pneumophila demonstrated that Naip 5 and NLRC 4 activate caspase- 1 and this inflammasome is activated by bacterial 
research fellow from CNPq, Brazil. The funders had no role in study design, data collection and analysis, decision to publish, or preparation of the manuscript.

Competing interests: The authors have declared that no competing interests exist. flagellin. However, macrophages and mice deficient in NLRC4 are more susceptible for $L$. pneumophila replication than those deficient in caspase-1, indicating that the flagellin/ Naip5/NLRC4 inflammasome triggers responses that are independent on caspase-1. Here, we used L. pneumophila to investigate this novel pathway and found that caspase-8 interacts with NLRC4 in a process that is dependent on ASC and independent of caspase-1 and caspase-11. Although caspase-8 is recruited to the Naip5/NLRC4/ASC inflammasome, it is only activated when caspase- 1 or gasdermin-D is inhibited. Our data suggest that caspase-8 activation in the Naip5/NLRC4/ASC inflammasome may favor host responses during infections against pathogens that inhibit components of the pyroptotic cell death including caspase-1 and gasdermin-D.

\section{Introduction}

Legionella pneumophila is the causative agent of Legionnaires' disease. It was identified for the first time in 1976, after an atypical pneumonia affected the participants of the American Legion Convention in Philadelphia, United States [1]. After isolation, L. pneumophila were characterized as Gram-negative, flagellated, intracellular facultative bacteria [2,3]. The species of Legionella were found mainly in freshwater and soil environments, including lakes and irrigation systems [4]. Infection of humans occurs upon inhalation of water droplets derived from these environments containing Legionella [5]. After inhalation, L. pneumophila can subvert the normal vesicle traffic within alveolar macrophages and form LCV (Legionella-containing vacuoles), a process that is mediated by the injection of hundreds of bacterial effectors through a type IV secretion system called Dot/Icm [6-9]. During its evolution, L. pneumophila were selected based on their replication in protozoa but not in humans, which are accidental hosts [10]. Consequently, L. pneumophila can be recognized by many innate immune receptors in mammalian cells, including proteins from the family of the nucleotide-binding domain and leucine-rich repeat-containing proteins (NLRs). These characteristics make L. pneumophila an excellent model for the study of innate immunity, including intracellular signaling pathways and inflammasomes.

The major inflammasome that leads to the restriction of Legionella replication in macrophages is Naip5/NLRC4. This pathway was discovered in mouse cells upon observations that macrophages from the $\mathrm{A} / \mathrm{J}$ mouse strain, but not cells from other mice strains, are susceptible to L. pneumophila replication [11]. The resistance was mapped to the Lgn1 locus, which encodes several copies of Naip genes, including Naip5 (Bircle), which is the gene responsible for resistance [12-16]. Successful lines of investigation culminated in the demonstration that Naip 5 recognizes bacterial flagellin and interacts with NLRC4 for caspase-1 activation and the restriction of bacterial replication [17-20]. This platform was named the Naip5/NLRC4 inflammasome and triggers pore formation and pyroptosis, which has been considered one of the most important mechanisms for the restriction of intracellular pathogen replication via inflammasomes [21-24]. Host cell death via pyroptosis eliminates intracellular parasite replication and traps intracellular microbes in pyroptotic cells, facilitating microbial destruction by additional phagocytes [23,25-29]. Pyroptosis occurs concomitantly with the secretion of inflammatory cytokines such as IL-1 $\beta$ and IL-18, a process that requires the adaptor molecule ASC and the formation of NLRC4/ASC puncta [20,30]. ASC also functions as an adaptor protein for other inflammasomes, including AIM2 and NLRP3, which triggers the processing of caspase-1 and caspase-8 [21,31-34]. Of note, Naip5/NLRC4 appears to be the only inflammasome required for the restriction of $L$. pneumophila replication. Macrophages that are deficient 
in NLRP3 or AIM2 can efficiently restrict L. pneumophila replication [20,21,23,35]. However, the participation of ASC in the resistance of $L$. pneumophila infection is controversial. In murine macrophages, ASC is dispensable for the induction of pyroptosis and the restriction of bacterial replication $[20,21]$. By contrast, experiments performed with human monocytes indicate that ASC silencing leads to an increase in bacterial replication [36,37]. Thus, the role of ASC in the restriction of L. pneumophila replication is still unclear.

We have previously demonstrated the existence of a pathway that is dependent on flagellin and NLRC4 but independent of caspase-1 [38]. Here, we used macrophages and Casp1/1 $1{ }^{-1}$ mice to systematically assess this pathway. By searching for additional components that operate in the NLRC4 inflammasome independently of caspase-1/11, we found that caspase- 8 interacts with NLRC4 in a process that is dependent on ASC. This pathway effectively accounts for resistance to infection in macrophages and in vivo when caspase- 1 is absent. In wild-type cells, caspase- 8 is recruited to the Naip5/NLRC4/ASC/caspase- 1 inflammasome, but is not activated. Caspase- 8 activation in this platform only occurs when caspase- 1 or gasdermin-D is inhibited, suggesting that this pathway may be important when pyroptosis is inhibited.

\section{Results}

\section{Restriction of $L$. pneumophila replication in BMDMs is flagellin/ NLRC4-dependent, ASC-independent and partially caspase-1/ 11-dependent}

We have previously demonstrated that activation of the flagellin/NLRC4 inflammasome triggers caspase-1-dependent and independent responses to restrict Legionella replication in macrophages and in mouse lungs [38]. However, the caspase-1-independent mechanisms underlying this pathway are unknown. To further characterize this pathway, we performed growth curves using high and very low multiplicity of infections (MOIs) in bone marrowderived macrophages (BMDMs). Macrophages were infected with wild-type L. pneumophila in the JR32 background (WT Lp) and the isogenic mutants fla $A^{-}$and fliI. FliI is an ATPase that is required for the secretion of flagellin through the flagellar apparatus [39]. Consequently, fliT mutants express flagellin but are non-motile and non-flagellated, making them an appropriate control for flaA- mutants for investigations related to the role of flagellin. We found that BMDMs from C57BL/6 and $A s c^{-1-}$ mice fully restrict the replication of WT Lp and fliT bacteria at low and high MOIs. In contrast, Nlrc $4^{-/-}$cells are permissive and Casp $1 / 11^{-1-}$ cells are partially restrictive (S1 Fig). Bacterial mutants for flagellin bypass NLRC4-mediated growth restriction and replicate in all macrophages as previously described $[17-19,40]$. These data support previous reports showing that ASC is not required for the restriction of L. pneumophila replication in the presence of caspase-1/11 [20,21]. In addition, these data further support our previous assertion that flagellin triggers an uncharacterized pathway that is dependent on NLRC4 and independent of caspase-1 and caspase-11 [38]. We decided to use BMDMs from Casp $1 / 11^{-1-}$ mice to further investigate this NLRC4-dependent and caspase-1/ 11-independent pathway.

\section{Flagellated $L$. pneumophila triggers NLRC4 puncta that associate with caspase-8 in a process that is ASC-dependent}

The transduction of BMDMs with a retrovirus encoding NLRC4 fused to GFP allows the visualization of NLRC4 puncta in the cytoplasm of macrophages infected with flagellated bacteria [30]. Here, we used this retroviral system to investigate the formation of the NLRC4 inflammasome in the absence of caspase-1/11. BMDMs from Casp $1 / 11^{-/}$mice were transduced with 
NLRC4-GFP and infected with WT Lp, fliI and $f l a A^{-}$at different MOIs and time points. We found that WT Lp and fliI triggered the formation of NLRC4 puncta in the absence of caspase-1/11 (Fig 1A). The formation of NLRC4 puncta was influenced by the MOI and significantly diminished in response to fla $A^{-}$bacteria (Fig 1A). Next, we evaluated the requirement of ASC for the formation of NLRC4 puncta in the absence of caspase-1/11. We constructed a mouse that was deficient in ASC and caspase-1/11 and found that whereas the formation of

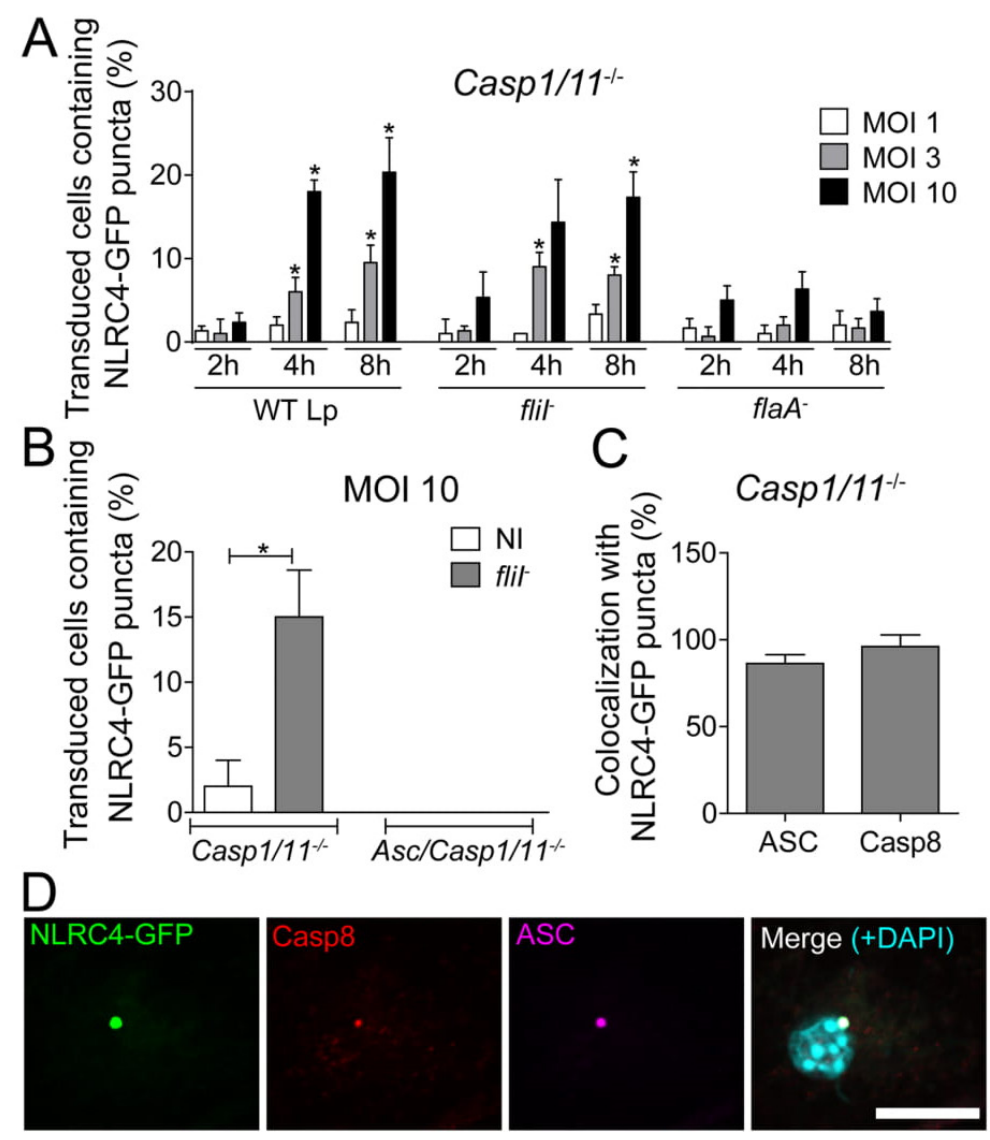

Fig 1. Legionella triggers the formation of NLRC4/caspase-8 puncta in a process that is dependent on ASC and flagellin and independent of caspase-1/11. Bone marrow-derived macrophages (BMDMs) obtained from Casp $1 / 11^{-\%}$ and Asc/Casp $1 / 11^{-1}$ mice were transduced with retrovirus encoding NLRC4-GFP. Cells were infected with wild-type L. pneumophila (WT Lp), motility-deficient mutants expressing flagellin (flii) or with flagellin-deficient mutants (flaA) at a MOI of 1,3 or 10 . (A) After 2, 4 and 8 hours of infection, the cells were fixed, and the percentage of transduced cells containing NLRC4-GFP puncta were determined using an epifluorescence microscope. *, $P<0.05$ compared with BMDMs infected with fla $A^{*}$, Student's $t$ test. (B-D) Transduced cells were infected with flir (MOI 10) and fixed after 8 hours of infection. (B) The percentages of transduced Casp $1 / 11^{-/}$and Asc/Casp $1 / 11^{-\%}$ cells containing NLRC4-GFP puncta were determined. (C) The percentages of NLRC4-GFP puncta that colocalized with ASC and caspase-8 were determined. (D) Representative images of a transduced BMDM infected with flir at a MOI of 10 . The cultures were stained with anti-caspase-8 (red) and anti-ASC (purple). The cell nuclei were stained with DAPI (cyan); NLRC4-GFP is shown in green. The images show the colocalization of NLRC4-GFP, ASC and caspase-8 in Casp $1 / 11^{-1}$ BMDMs. The images were acquired by multiphoton microscopy using a $63 \mathrm{x}$ oil immersion objective and analyzed using ImageJ Software. Scale bar, $10 \mu \mathrm{m}$. Data show the average \pm SD of triplicate wells. NI, uninfected. Data are presented for one representative experiment of five (A) and two (B-D) experiments with similar results.

https://doi.org/10.1371/journal.ppat.1006502.g001 
NLRC4 puncta occurred in the absence of caspase-1/11, ASC was essential for formation of the NLRC4 puncta (Fig 1B). These data are in agreement with previous findings indicating that ASC is critical for the nucleation of several inflammasomes, including AIM2, NLRP3 and NLRC4 [30,32,33,41-46]. Our results confirm that ASC is essential to NLRC4 puncta formation formed in the absence of caspase-1/11. Next, we used this NLRC4-GFP system to identify additional components of the NLRC4 inflammasome that operates in the absence of caspase$1 / 11$. Non-inflammatory caspases have been previously shown to participate in the assembly of inflammasomes and to interact with ASC, including caspase-3, caspase-7 and caspase-8 [3234,37,44,46-51]. Thus, we transduced Casp $1 / 11^{-1}$ macrophages with a retrovirus encoding NLRC4-GFP and evaluated the colocalization of NLRC4 with these caspases. In this experiment, we used the pan-caspase inhibitor Z-VAD to block caspase activation and to visualize puncta formation. We did not detect significant numbers of NLRC4 or ASC puncta containing caspase- 3 and caspase-7 (S2 Fig). In contrast, caspase-8 and ASC was present in more than 90\% of the NLRC4 puncta (Fig 1C and S2 Fig). These data are in agreement with our findings indicating that ASC is required for NLRC4 puncta formation, accordingly, endogenous ASC colocalizes with NLRC4 and caspase- 8 in the same puncta (Fig 1D). To evaluate the participation of caspase- 8 in the NLRC4 inflammasome, we transduced BMDMs from Casp $1 / 11^{-1 /}$ mice with a retrovirus encoding ASC fused to GFP (ASC-GFP) and analyzed ASC puncta colocalization with caspase- 8 . We found that ASC puncta formed readily after the infection and that this process occurred in response to WT Lp and fliT but not flaA- (Fig 2A). After 8 hours of infection, the formation of ASC puncta was partially dependent on flagellin (Fig $2 \mathrm{~A}$ ). We stained caspase- 8 in macrophages transduced with retrovirus encoding ASC-GFP and found that caspase- 8 colocalized with ASC puncta in response to infection with flagellated bacteria (Fig 2B). Collectively, these results indicate that flagellin triggers the assembly of an inflammasome composed of NLRC4 and ASC, which colocalizes with caspase-8.

The double-stranded DNA sensor AIM2 is known to recruit ASC to trigger puncta formation in response to infection, leading to caspase-1 activation and IL- $1 \beta$ and IL-18 release [31,52-55]. The role of AIM2 inflammasome in the recognition of L. pneumophila has been demonstrated using $s d h A^{-}$deficient bacteria. In the absence of SdhA, bacteria do not maintain vacuole integrity and localize in the macrophage cytoplasm, triggering activation of the AIM2 inflammasome [56,57]. In addition, the AIM2 inflammasome has been shown to trigger caspase- 8 activation independently of caspase- $1[33,34,58]$. Thus, we investigated whether AIM2 is present in the NLRC4/ASC/caspase-8 inflammasome that is formed in response to flagellinpositive L. pneumophila. We stained AIM2 in macrophages transduced with retrovirus encoding NLRC4-GFP and found no AIM2 in the NLRC4 puncta (S3A Fig). Moreover, we generated Aim $2 /$ Casp $1 / 11^{-/}$mice and found that AIM2 was dispensable for the formation of NLRC4 puncta in response to flagellin-positive bacteria (S3B Fig).

\section{The NLRC4/ASC/caspase-8 inflammasome accounts for flagellin- dependent restriction of Legionella replication in macrophages in the absence of caspase-1/11}

Our data are consistent with the hypothesis that caspase- 8 is a part of the inflammasome composed of NLRC4 and ASC. Thus, we investigated whether caspase-8 is activated during infection. We found that caspase- 8 was strongly activated in Casp $1 / 11^{-/-}$BMDMs in response to $f l i$ but not $f l a A^{-}$bacteria (Fig $3 \mathrm{~A}$ ). In agreement with the requirement of ASC for the assembly of the NLRC4/ASC/caspase- 8 inflammasome, we found that caspase-8 activation was abolished in Asc/Casp $1 / 11^{-/}$cells (Fig 3A). Caspase-8 activation occurred normally in Aim2/Casp $1 / 11^{-/}$ cells, indicating that AIM2 was not involved in the activation of caspase- 8 through the 
flagellin/NLRC4/ASC inflammasome (S4 Fig). We also evaluated caspase-8 activation by western blot analysis by measuring the cleavage of $\mathrm{p} 55$ and the production of $\mathrm{p} 18$ isoforms. We found that flagellated bacteria triggered caspase-8 activation in Casp $1 / 11^{-1-}$ but not in Asc/ Casp $1 / 11^{/-}$cells. This phenomenon was evident by the reduction in $\mathrm{p} 55$ and increased production of p18 in Casp 1/11 $1^{-/}$BMDMs infected with fliT but not flaA $A^{-}$bacteria (Fig 3B).

Next, we evaluated the participation of caspase-8 in caspase-1/11-independent restriction of $L$. pneumophila replication in macrophages, a process that was dependent on flagellin and NLRC4. Endogenous caspase- 8 was silenced in Casp $1 / 11^{-/-}$BMDMs using two independent retrovirus encoding shRNA to target caspase- 8 . A non-target sequence was used as a control (NT). By western blotting, we detected reduced caspase-8 expression in Casp $1 / 11^{-/}$transduced cells. The shRNA Casp8 Seq1 was more efficient than Seq2 for silencing caspase-8 as determined by western blot (Fig 4A and S5 Fig) and RT-PCR (Fig 4B). Importantly, complete silencing of caspase- 8 cannot be achieved because caspase- 8 expression is required for macrophage survival $[59,60]$. Nonetheless, using the described silencing conditions, we did not detect signs of cell death or LDH in the supernatant of the transduced macrophages. To evaluate the efficiency of caspase-8 silencing, we quantified caspase-8-containing puncta formation and caspase- 8 activation in macrophages infected with flagellated L. pneumophila. We found that the frequency of puncta containing caspase- 8 and caspase- 8 activation was reduced in caspase-

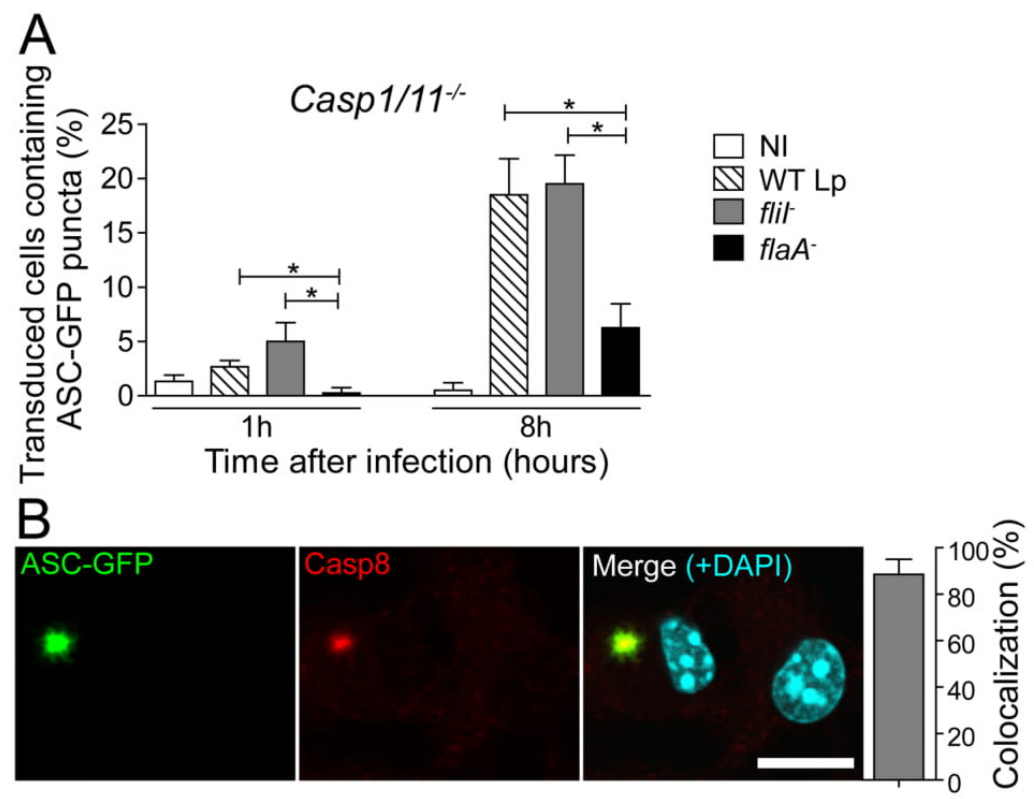

Fig 2. ASC puncta are induced in response to flagellated bacteria and colocalize with caspase-8. Bone marrow-derived macrophages (BMDMs) from Casp $1 / 11^{-}$mice were transduced with retrovirus encoding ASC-GFP. (A) Cells were infected with wild-type L. pneumophila (WT Lp), motility-deficient mutants expressing flagellin ( flir) or with flagellin-deficient mutants ( $f l a A$ ) at a MOI of 10 . After 1 or 8 hours of infection, the cells were fixed, and the number of transduced cells containing ASC-GFP puncta was determined using an epifluorescence microscope. (B) Representative images of a transduced BMDM infected with flir at a MOI of 10 . The cultures were stained with anti-caspase-8 (red), cell nuclei were stained with DAPI (cyan) and ASC-GFP is shown in green. The images show the colocalization between ASC-GFP and caspase- 8 in Casp $1 / 11^{\%}$ BMDMs infected for 8 hours. The images were acquired by multiphoton microscopy with a $63 x$ oil immersion objective and analyzed using ImageJ Software. Scale bar, $10 \mu \mathrm{m}$. Data show the average \pm SD of triplicate wells. ${ }^{*}, P<0.05$, Student's $t$ test. NI, uninfected. Data are presented for one representative experiment of three $(A)$ and two $(B)$ experiments with similar results.

https://doi.org/10.1371/journal.ppat.1006502.g002 
8 -silenced cells (Fig 4C and 4D). Next, we evaluated the effect of caspase- 8 for the restriction of L. pneumophila replication in Casp1/11 $1^{-/}$BMDMs. We found that silencing caspase- 8 culminated in increased replication of fliT but not flaA $A^{-}$bacteria (Fig $4 \mathrm{E}$ and $4 \mathrm{~F}$ ). These data indicated that caspase- 8 contributed to the restriction of bacterial replication in a process that was dependent on flagellin, supporting the hypothesis that caspase- 8 functionally participates in responses that are NLRC4/ASC-dependent and caspase-1/11-independent.

\section{ASC is required for NLRC4/caspase-8-mediated restriction of Legionella replication in the absence of caspase-1/11}

Our data indicate that caspase- 8 is part of the NLRC4/ASC inflammasome and that ASC is essential for the assembly of this inflammasome. Thus, we reasoned that in the absence of
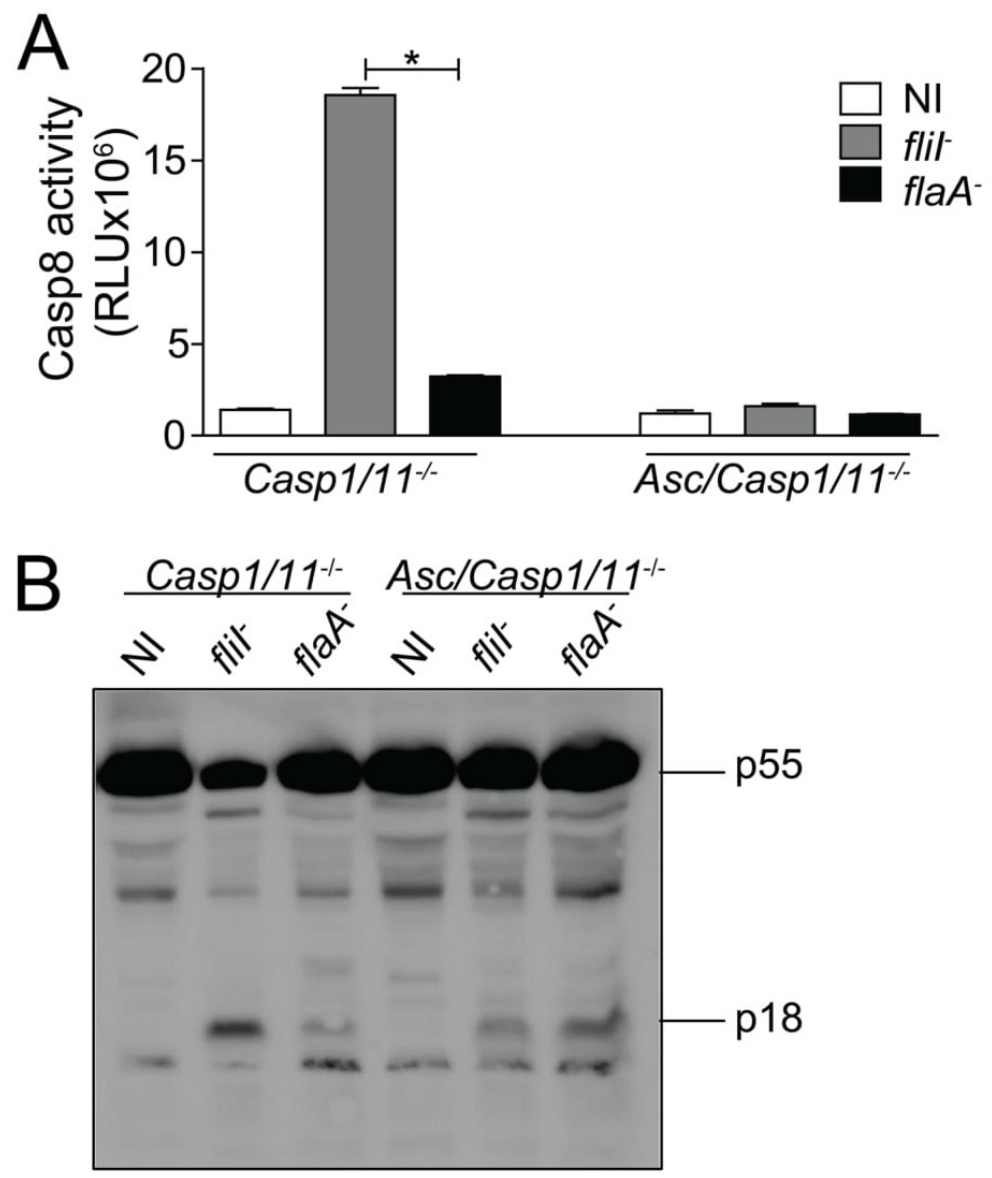

Fig 3. Caspase-8 is activated in response to flagellated bacteria in a process that is ASC-dependent and caspase-1/11-independent. Bone marrow-derived macrophages (BMDMs) from Casp1/11 ${ }^{-1}$ and Asc/ Casp $1 / 11^{-/}$mice were infected with motility-deficient $L$. pneumophila mutants expressing flagellin (flir) or with flagellin-deficient bacteria $\left(f l a A^{-}\right)$at a $\mathrm{MOI}$ of 10 for 8 hours. The activity of caspase- 8 was measured using the Caspase-8 Glo Assay (A) or by western blot analysis (B). The pro-caspase-8 p55 and the processed form of caspase-8 p18 are indicated. Data show the average \pm SD of triplicate wells. ${ }^{*}, P<0.05$, Student's $t$ test. RLU, relative luminescence units; $\mathrm{NI}$, uninfected. Data are presented for one representative experiment of three $(A)$ and two (B) experiments with similar results.

https://doi.org/10.1371/journal.ppat.1006502.g003 
A

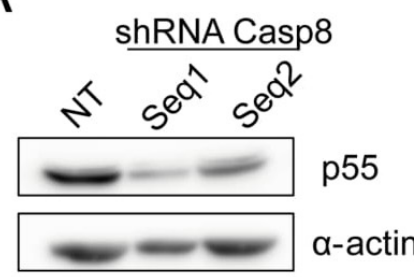

C

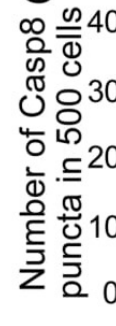
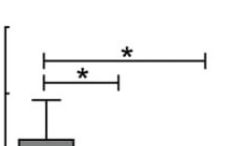

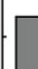

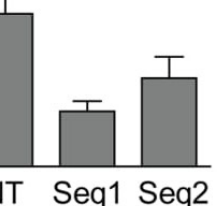

NT Seq1 Seq2

- NT ShRNA

$\because$ shRNA Casp8 Seq1

shRNA Casp8 Seq2

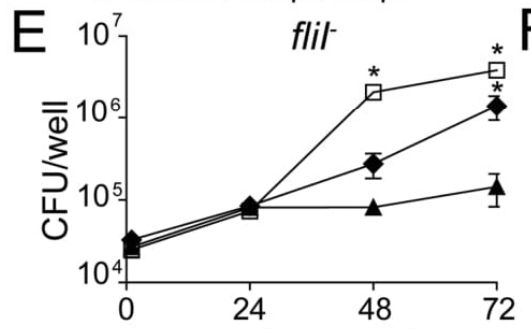

Time after Infection (hours)
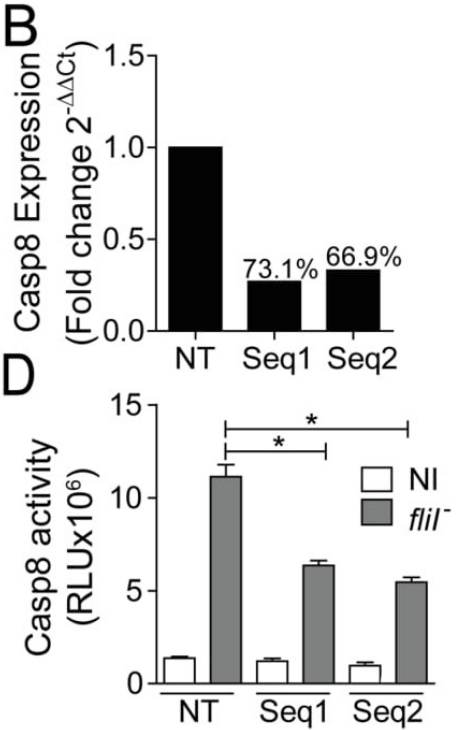

Fig 4. Caspase-8 is important for NLRC4-mediated restriction of $L$. pneumophila replication independently of caspase-1/11. Bone marrow-derived macrophages (BMDMs) generated from Casp1/11 mice were transduced with a retrovirus encoding shRNA sequences to target caspase-8 (Seq1, Seq2) and a non-target shRNA sequence (NT). (A) The silencing was confirmed by western blot analysis and Real Time qPCR. (A) Cell lysates were separated by SDS-PAGE, blotted and probed with anti-caspase-8 (pro-caspase8 p55) and anti- $\alpha$-actin. (B) Quantification of the casp8 gene expression by Real Time qPCR. Actin beta gene was used as a control for normalization of expression levels. The number above the bars indicates the percentage of silencing compared to the NT sequence. (C-D) The transduced Casp $1 / 11^{-1 /}$ BMDMs were infected with motility-deficient $L$. pneumophila mutants expressing flagellin (flir) at a MOI of 10 . After 8 hours the cells were fixed, the number of caspase- 8 puncta was quantified using an epifluorescence microscope (C) and the activity of caspase- 8 was measured using the Caspase- 8 Glo Assay (D). (E-F) The transduced Casp $1 / 11^{-1}$ BMDMs were infected with flir $(\mathrm{E})$ and $f l a A^{-}(\mathrm{F})$ at a MOI of 10 to evaluate bacterial replication. The cells were incubated for 24,48 and 72 hours for CFU determination. Data show the average \pm SD of triplicate wells. ${ }^{*} P<0.05$, compared with NT. (C-D) Student's $t$ test, (E-F) ANOVA. RLU, relative luminescence units; $\mathrm{NI}$, uninfected. Data are presented for one representative experiment of three experiments with similar results.

https://doi.org/10.1371/journal.ppat.1006502.g004

ASC, the NLRC4/ASC/caspase-8 inflammasome would not be functional. If this hypothesis is correct, Asc/Casp $1 / 11^{-/}$macrophages should be more permissive than Casp $1 / 11^{-/-}$and as permissive as $\mathrm{Nlrc}^{-/-}$. We infected C57BL/6, Casp $1 / 11^{-/}$, Asc/Casp $1 / 11^{-/-}$and Nlrc4 $4^{-/-}$BMDMs 
with $f l i \Gamma$ and $f l a A^{-}$, and evaluated bacterial replication after 24,48 and 72 hours. Using flagellin-positive bacteria, we confirmed that C57BL/6 BMDMs were restrictive to bacterial growth, $\mathrm{NlrC4}^{-/}$were permissive and Casp $1 / 11^{-/}$were partially restrictive (Fig 5A). Importantly, Asc/
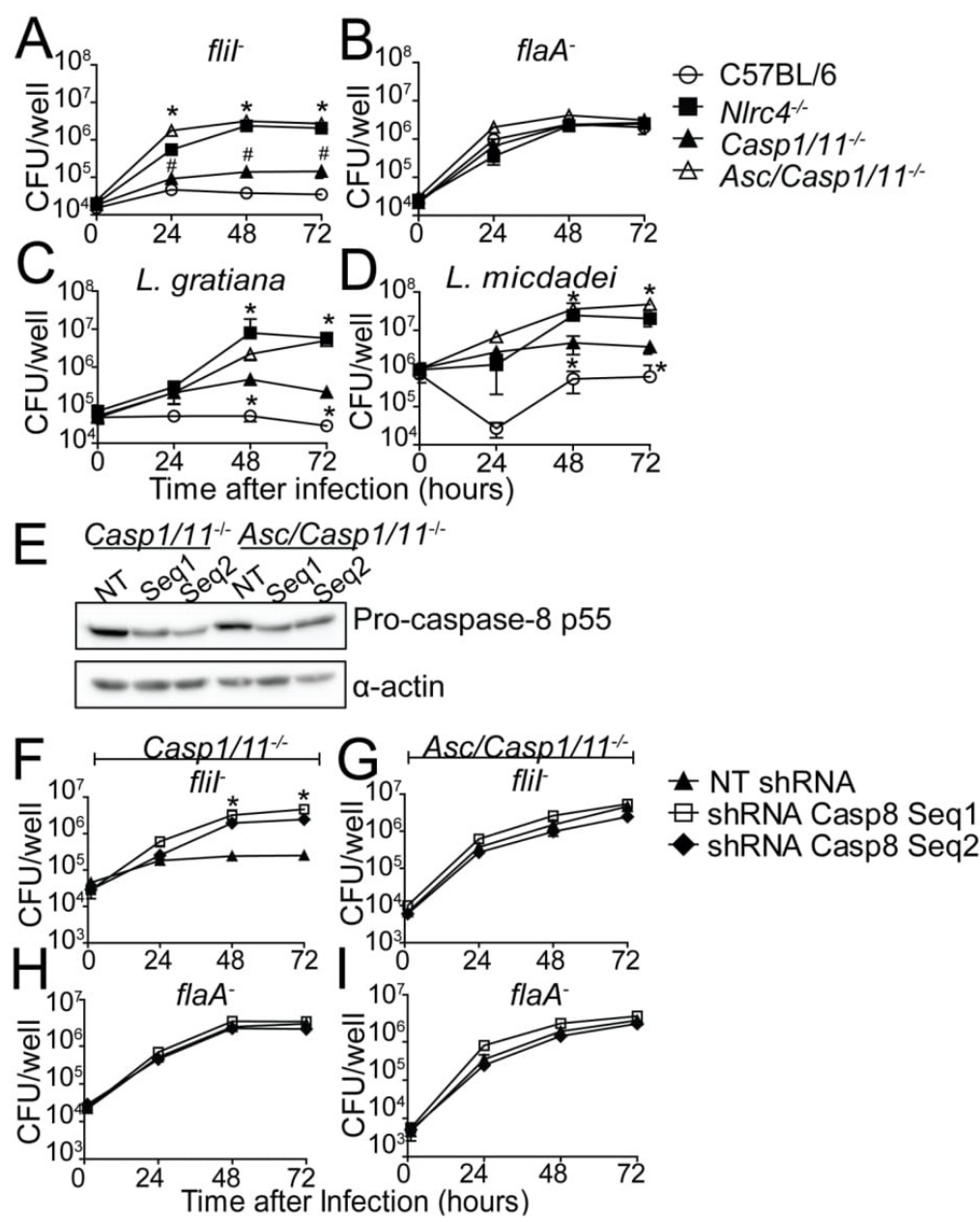

Fig 5. ASC is important for NLRC4/caspase-8-mediated restriction of $L$. pneumophila replication independently of caspase-1/11. (A-D) Bone marrow-derived macrophages (BMDMs) from C57BL/6 (open circles), NIrc4 $4^{\%}$ (closed squares), Casp $1 / 11^{\%}$ (closed triangles) and Asc/Casp 1/11\% (open triangles) mice were infected with motility-deficient mutants expressing flagellin (flir, A), with flagellin-deficient mutants $\left(f l a A^{-}\right.$, B), L. gratiana (C) or with L. micdadei (D) at a MOI of 10 . The cells were incubated for 24,48 and 72 hours for CFU determination. Data show the average \pm SD of triplicate wells. ${ }^{*}, P<0.05$ compared with Casp-1/11 BMDMs. ",$P<0.05$ compared with C57BL/6 BMDMs, ANOVA. (E-I) BMDMs from Casp1/11/\% and Asc/Casp1/ $11^{1 /}$ mice were transduced with a retrovirus encoding shRNA sequences to target caspase-8 (Seq1, Seq2) and a non-target shRNA sequence (NT). (E) Caspase-8 silencing was confirmed by western blot analysis. Cell lysates were separated by SDS-PAGE, blotted and probed with anti-caspase-8 (pro-caspase-8 p55) and anti- $\alpha$-actin. (F-I) Transduced $\operatorname{Casp1/11\% }(\mathrm{F}, \mathrm{H})$ and $A s c / C a s p 1 / 11^{\%}(\mathrm{G}, \mathrm{I}) \mathrm{BMDMs}$ were infected with flir (F, $\mathrm{G})$ or $\mathrm{flaA}^{-}(\mathrm{H}, \mathrm{I})$ at a $\mathrm{MOI}$ of 10 and incubated for 24,48 and 72 hours for CFU determination. Data show the average \pm SD of triplicate wells. ${ }^{*}, P<0.05$ compared with NT shRNA, ANOVA. NT, non-target shRNA. Data are presented for one representative experiment of four (A), two (B-D) and one (F-I) experiments performed with similar results.

https://doi.org/10.1371/journal.ppat.1006502.g005 
Casp $1 / 11^{-/}$cells were highly permissive and phenocopied the Nlrc4 $4^{-/}$cells (Fig $\left.5 \mathrm{~A}\right)$. As predicted, flagellin mutants bypassed the NLRC4 and replicated in all macrophages evaluated (Fig 5B). These data further confirmed that Casp $1 / 11^{-/-}$cells were more restrictive than $\mathrm{Nlrc} 4^{-/-}$ macrophages, possibly due to the presence of the NLRC4/ASC/caspase-8 inflammasome. We also used non-pneumophila species to compare bacterial replication in $\mathrm{NlrC}^{-/-}$and $\mathrm{Ascl}$ Casp $1 / 11^{-/}$macrophages. Infections performed with L. gratiana and L. micdadei indicated that $\mathrm{Asc} / \mathrm{Casp} 1 / 11^{-/-}$macrophages were as susceptible as $\mathrm{Nlrc}^{-{ }^{-\alpha}}$, whereas Casp $1 / 11^{-/}$cells were partially restrictive (Fig 5C and 5D). Similar experiments performed with Aim $2 /$ Casp $1 / 11^{-/}$ macrophages did not support the role of AIM2 in the NLRC4/ASC-dependent growth restriction that occurred in the absence of caspase-1/11 (S6 Fig). These data indicate that flagellated species of Legionellae trigger NLRC4 responses that are independent of caspase-1/11 but dependent on ASC. To further confirm the participation of caspase-8 in this NLRC4/ASC inflammasome, we silenced caspase- 8 in Casp $1 / 11^{-/-}$and Asc/Casp $1 / 11^{-/-}$macrophages. We confirmed the silencing by western blot analysis (Fig 5E and S7 Fig) and found that the reduction in caspase-8 expression impaired the restriction of bacterial replication in Casp $1 / 11^{-/}$ infected with $f l i \Gamma$ (Fig 5F). Inhibition of caspase-8 expression affected neither the replication of $f l i \Gamma$ in Asc/Casp1/11 $1^{-/}$cells (Fig 5G) nor the replication of $\mathrm{flaA}^{-}$in Casp $1 / 11^{-/-}$and in Asc/ Casp $1 / 11^{-1-}$ cells (Fig $5 \mathrm{H}$ and 5I). Collectively, these data are consistent with the hypothesis that flagellin activates a response that is dependent on NLRC4, ASC and caspase- 8 and occurs in the absence of caspase-1/11.

$\mathrm{Casp}^{-{ }^{--}}$mice are embryonic lethal [59], and we were not able to generate Casp $8 / 1 / 11^{-1-}$ mice. Since the deletion of ASC impairs the assembly of the NLRC4/ASC/caspase- 8 inflammasome and caspase- 8 activation, we used Asc/Casp $1 / 11^{-/}$mice to assess the role of the NLRC4/ ASC/caspase-8 inflammasome in the restriction of Legionella replication in vivo. Using flagellin-positive bacteria such as L. pneumophila, L. gratiana and L. micdadei, we demonstrated that $A s c / C a s p 1 / 11^{-/-}$mice were highly permissive to bacterial replication and phenocopied infection of $\mathrm{Nlrc}^{-/-}$mice (Fig 6A-6C). Casp1/11 $1^{-/}$mice were more permissive than C57BL/6, but they were less permissive than $\mathrm{Nlrc} 4^{-/-}$mice (Fig 6A-6C). Experiments performed with fli and $\mathrm{flaA} \mathrm{A}^{-}$indicated that $\mathrm{Asc} / \mathrm{Casp} 1 / 11^{-/}$were more permissive than Casp $1 / 11^{-/-}$when infected with fliT but not flaA (Fig 6D). To determine whether AIM2 accounted for the restriction of bacterial replication in the absence of caspase-1/11, we compared infection of Aim2/Casp1/ $11^{-/}$with Casp $1 / 11^{-/}$. We found that Aim $2 /$ Casp $1 / 11^{-/}$and Casp $1 / 11^{-/}$supported similar replication levels of fliT L. pneumophila in the lungs. In contrast, Asc/Casp $1 / 11^{-/}$and $\mathrm{Nlrc} 4^{-/-}$mice were significantly more permissive to bacterial replication (S8 Fig). Collectively, these data indicate that AIM2 is dispensable for the functions of the NLRC4/ASC/caspase-8 inflammasome. This molecular platform is assembled in response to flagellin-positive bacteria and operates to restrict bacterial replication in vitro and in vivo in a process that is independent of both caspase-1 and caspase-11.

\section{Activation of the NLRC4/ASC/caspase-8 inflammasome triggers pore formation and cell death}

Activation of caspase-1 inflammasomes induces pyroptosis and contributes to the restriction of infection by flagellated bacteria such as L. pneumophila, Salmonella typhimurium and Burkholderia thailandensis [23]. Accordingly, we have previously demonstrated that L. pneumophila trigger pyroptosis in a process mediated by caspase- 1 and caspase-11, which are activated in response to flagellin and LPS, respectively $[20,24,35,61]$. Thus, we investigated whether activation of the NLRC4/ASC/caspase-8 inflammasome could trigger cell death in Casp1/11 1 macrophages. We assessed membrane permeabilization fluorometrically in real time via the 


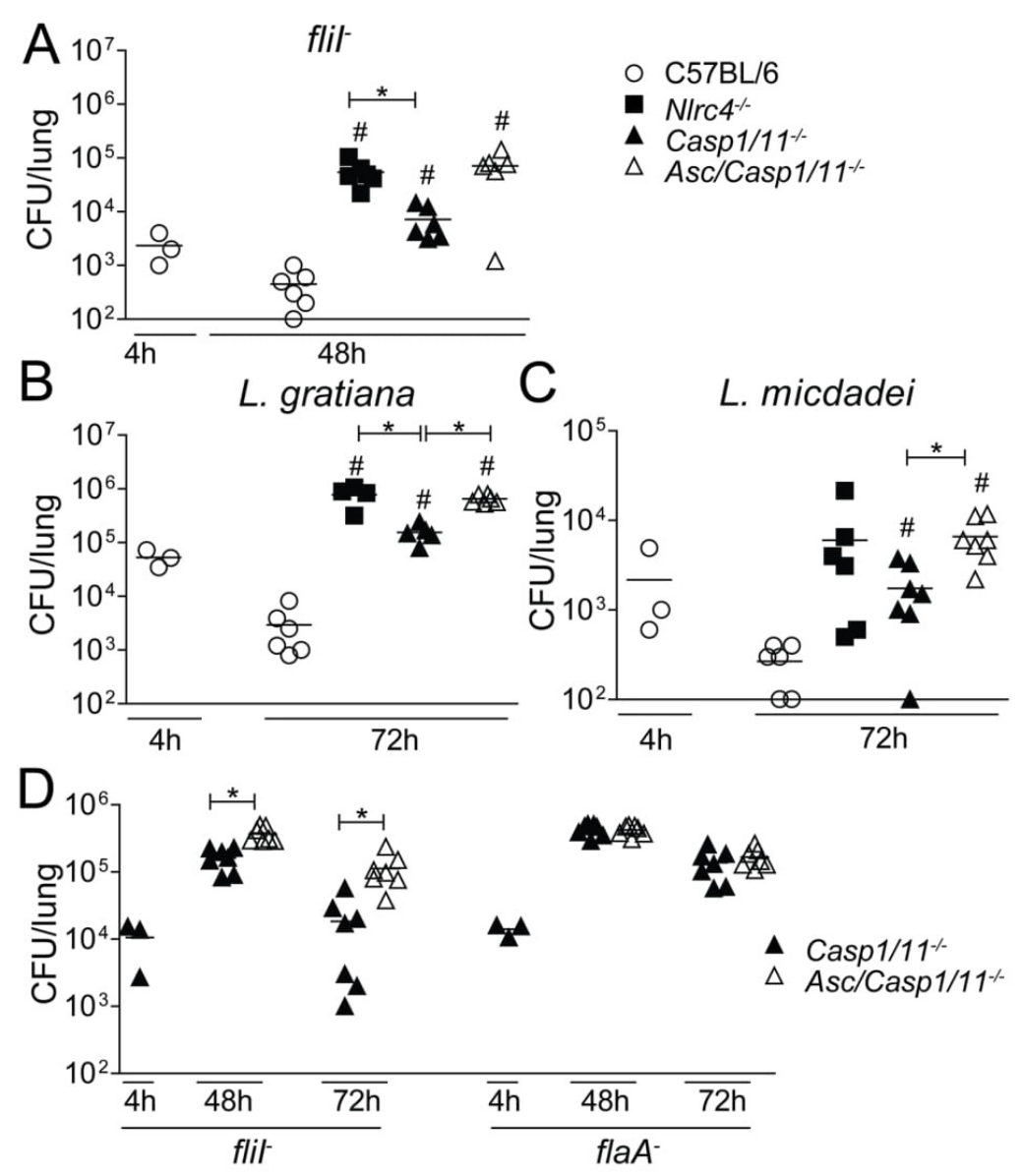

Fig 6. ASC is essential for NLRC4-mediated restriction of $L$. pneumophila replication independently of caspase-1/11 in vivo. C57BL/6 (open circles), NIrc4 $4^{-1}$ (closed squares), Casp 1/1 $1^{-1 /}$ (closed triangles) and Asc/Casp $1 / 11^{-1-}$ (open triangles) mice were infected with motility-deficient $L$. pneumophila mutants expressing flagellin (flir, A, D), with flagellin-deficient $L$. pneumophila $\left(f l a A^{\prime}, \mathrm{D}\right)$, with $L$. gratiana (B) or with $L$. micdadei (C) at a dose of $10^{5}$ bacteria/mice. The mice were euthanized at 4,48 or 72 hours after infection. Dilutions of the lung homogenates were added to charcoal-yeast extract agar plates for colony-forming unit determination. Each dot represents a single animal, and the horizontal lines represent the averages. ${ }^{*}, P<0.05$. ${ }^{*}$, indicates $P<0.05$ compared with C57BL/6, Mann Whitney test. Data are presented for one representative experiment of five $(A)$, one (B-C) and two (D) experiments performed with similar results.

https://doi.org/10.1371/journal.ppat.1006502.g006

uptake of propidium iodide. Macrophages were infected with $f l i \Gamma$ or $f l a A^{-}$, and pore formation was monitored in real time for 6 hours. C57BL/6 macrophages triggered robust pore formation in response to infection with $f l i \Gamma$ and reduced pore formation in response to $\mathrm{flaA}^{-}$(Fig $7 \mathrm{~A}-7 \mathrm{C}$ ). The pore formation observed in $\mathrm{C} 57 \mathrm{BL} / 6$ macrophages infected with flaA mutants was dependent on caspase-11 [61] and will not be addressed herein. Importantly, despite the absence of both caspase-1 and caspase-11, we detected significant pore formation in Casp1/ $11^{-/}$cells infected with fliT (Fig 7B). This response was not detected in Casp $1 / 11^{-/}$cells infected with $\mathrm{flaA}^{-}$or in Asc/Casp $1 / 11^{-/}$macrophages infected with fliI or flaA (Fig 7B and 7C). These data support the hypothesis that NLRC4/ASC/caspase-8 induces pore formation. Experiments 

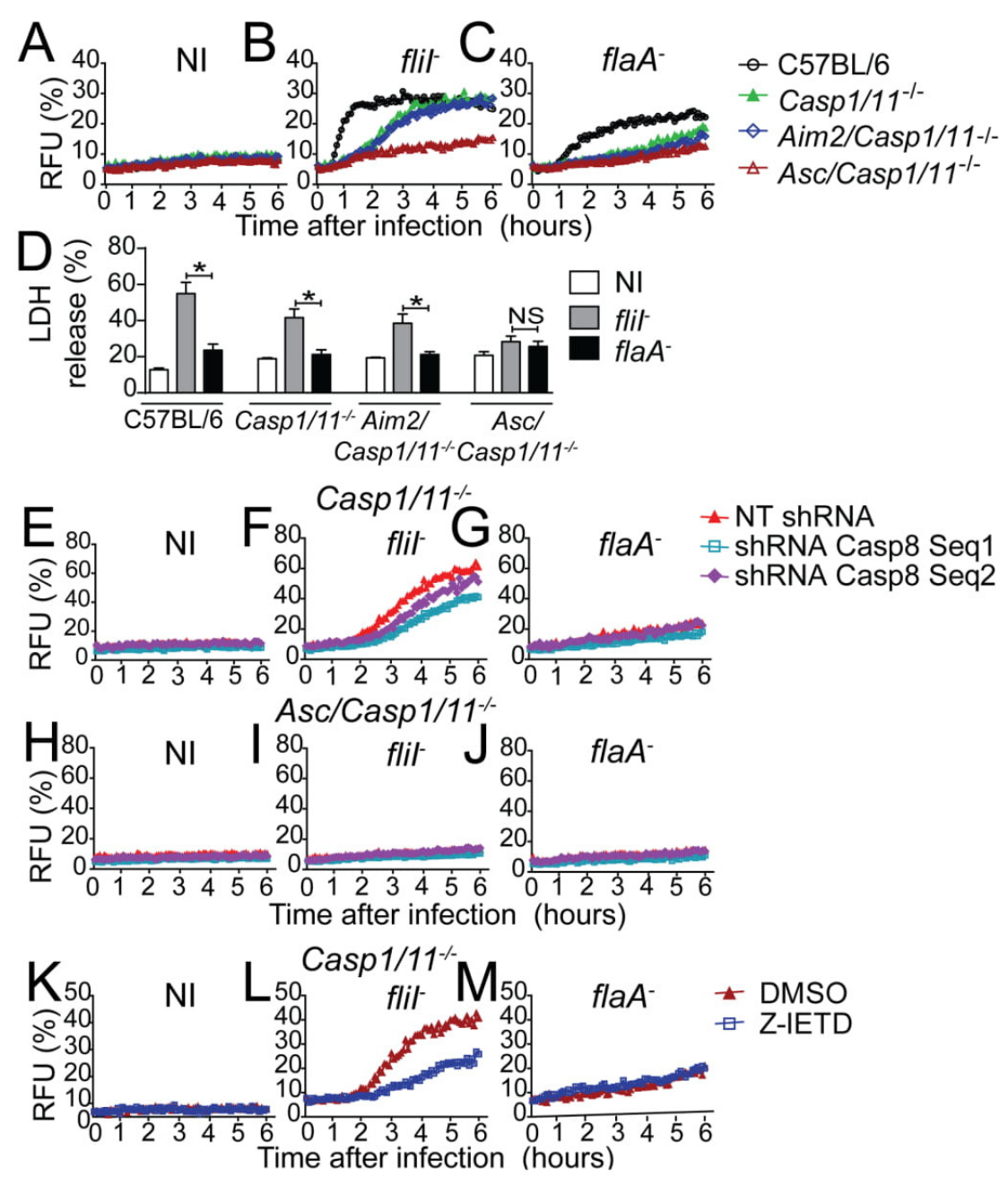

Fig 7. The NLRC4/ASC/caspase-8 inflammasome is important for pore formation and cell death independently of caspase-1/11. (A-D; K-M) Bone marrow-derived macrophages (BMDMs) were generated from C57BL/6, Casp 1/1 1 $\%$, Aim2/Casp $1 / 11^{\%}$ and Asc/Casp $1 / 11^{\%}$ mice and infected with motility-deficient $L$. pneumophila mutants expressing flagellin ( $f l i r)$ or with flagellin-deficient bacteria $\left(f l a A^{-}\right)$at a $\mathrm{MOI}$ of 5 . (E-J) BMDMs were transduced with retrovirus encoding shRNA sequences to target caspase-8 (Seq1, Seq2) and a non-target shRNA sequence (NT) and infected with flir or flaA $A^{-}$at a MOI of 5. (A-C; E-J) Pore formation was assessed fluorometrically in real time by the uptake of propidium iodide. RFU (\%) represents the percentage of RFU estimated with cells lysed with Triton X-100. (D) LDH release was measured using the CytoTox 96 $\mathrm{LDH}$-release kit. The $\mathrm{LDH}$ release $(\%)$ represents the percentage of $\mathrm{LDH}$ release estimated with cells lysed with Triton X-100. (K-M) BMDMs were treated with $50 \mu \mathrm{M}$ of Z-IETD or DMSO for 1 hour and infected with (L) flir or (M) flaA at a MOI of 5. Pore formation was assessed fluorometrically in real time by the uptake of propidium iodide. Data show the average \pm SD of triplicate wells. ${ }^{*}, P<0.05$, Student's t test. NS, not significant; RFUs, relative fluorescence units; $\mathrm{NI}$, uninfected. Data are presented for one representative experiment of five (A-C), three (E-J) and two (D and K-M) experiments with similar results.

\section{https://doi.org/10.1371/journal.ppat.1006502.g007}

performed using Aim2/Casp1/11 $1 /$ macrophages corroborate our previous findings, indicating that AIM2 is not required for the activities of the NLRC4/ASC/caspase- 8 inflammasome (Fig $7 \mathrm{~B}$ and $7 \mathrm{C})$. Pore formation induced in response to caspase- 1 and caspase-11 activation 
culminates with the induction of macrophage lysis, a process that can be assessed by the presence of LDH in tissue culture supernatants $[24,61,62]$. Thus, we measured LDH release in the supernatants of macrophages infected with fliT and flaA $^{-}$for 8 hours. By comparing Casp1/ $11^{-/}$and $A s c / C a s p 1 / 11^{-/}$cells, we found that macrophage lysis occurred despite the absence of caspase-1/11 (Fig 7D). Cell death was flagellin-dependent because infections with fliT but not $\mathrm{flaA}^{-}$induced LDH release (Fig 7D). The participation of caspase- 8 in pore formation and cell death induced in caspase-1/11-deficient macrophages was evident using both MOI 5 (Fig 7) and MOI 10 (S9 Fig). Importantly, cell death was not observed in Asc/Casp $1 / 11^{-/}$, a feature that corroborates the pore formation studies and indicates that the NLRC4/ASC/caspase-8 inflammasome triggers pore formation and lysis of infected cells. We also assessed whether the NLRC4/ASC/caspase-8 inflammasome was important for the activation of inflammatory cytokines. We found that whereas C57BL/6 macrophages readily triggered the production of IL-1 $\beta$ after 24 hours of infection with flagellated bacteria, the Casp $1 / 11^{--}$or $A s c / C a s p 1 / 11^{-/}$deficient cells do not trigger a IL-1 $\beta$ production (S10A Fig). The production of IL-12p40 by these cells confirmed that all macrophages were primed and could respond to L. pneumophila infection (S10B Fig). To evaluate the participation of caspase- 8 in cell death induced by the NLRC4/ ASC/caspase- 8 inflammasome, we silenced endogenous caspase- 8 using shRNA. Macrophages that were transduced with retrovirus encoding shRNA did not exhibit pore formation before infection, indicating that transduction itself did not trigger cell death (Fig $7 \mathrm{E}$ and $7 \mathrm{H}$ ). In contrast, pore formation was evident in Casp $1 / 11^{-/-}$but not in Asc/Casp $1 / 11^{-/}$macrophages in response to fliT infection (Fig $7 \mathrm{~F}$ and $7 \mathrm{I}$ ). Pore formation induced in Casp $1 / 11^{-/-}$was diminished in caspase-8-silenced cells (Fig 7F). In support of the role of flagellin for triggering these responses, we did not detect pore formation in cells infected with flaA $^{-}$(Fig $7 \mathrm{G}$ and 7J). To further evaluate the participation of caspase- 8 in pore formation induced by flagellin, we performed pore formation assays using Z-IETD, a cell permeable peptide that binds irreversibly to the catalytic site of caspase-8 [63-65]. We found that treatment of Casp $1 / 11^{-1}$ macrophages with DMSO or Z-IETD did not cause pore formation in uninfected cells (Fig 7K). However, Z-IETD treatment reduced the pore formation induced by fli (Fig 7L) but not by flaA- (Fig $7 \mathrm{M})$. Collectively, these data indicate that flagellin-positive bacteria trigger pore formation and cell death-independent of caspase-1/11 via a process that requires ASC and caspase-8.

\section{Naip5 is required for NLRC4/ASC/caspase-8 inflammasome activation in response to flagellated Legionella}

Our data reveal that the NLRC4/ASC/caspase- 8 inflammasome is activated in Casp $1 / 11^{-1-}$ macrophages in response to infection with flagellated Legionella. To evaluate if Naip5 is required for activation of this inflammasome, we used shRNA to silence endogenous Naip5. In Naip5 silenced Casp $1 / 11^{-/}$macrophages, we detected a reduced activation of caspase- 8 in response to WT Lp and $f l i \Gamma$ bacteria (Fig 8A). Naip5 silencing was confirmed by RT-PCR (Fig 8B). We also tested if Naip5 is important for pore formation induced via caspase- 8 in Casp $1 / 11^{-/-}$macrophages. By evaluating pore formation, we found that Naip 5 is important for efficient pore formation in response to WT Lp and fliT bacteria (Fig 8D-8E). As previously reported, no pore formation was detected in response to $\mathrm{flaA}^{-}$bacteria (Fig 8F) or in Asc/Casp 1/11 $1^{-1-}$ macrophages (Fig 8G-8J). Finally, we tested if Naip5 is important for restriction of L. pneumophila replication in Casp $1 / 11^{-/}$macrophages. We found that Naip5 is important for restriction of flagellin-positive L. pneumophila replication in Casp 1/11 $1^{-/}$macrophages (Fig 8K). Naip5 silencing did not affect the replication of $f l a A^{-}$bacteria in Casp $1 / 11^{-/}$macrophages (Fig 8L). As predicted, Asc/Casp $1 / 11^{-/-}$macrophages were permissive to replication of both flaA $A^{-}$and fli bacteria and Naip5 did not influenced this process (Fig $8 \mathrm{M}$ and $8 \mathrm{~N}$ ). Taken together, these 

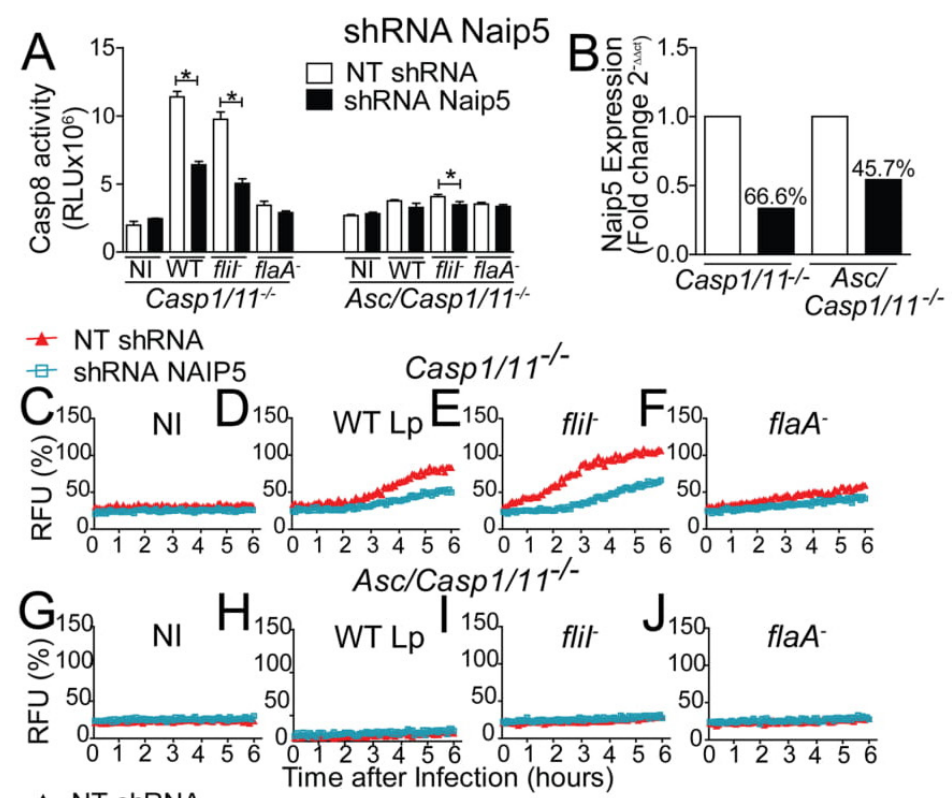

- NT shRNA

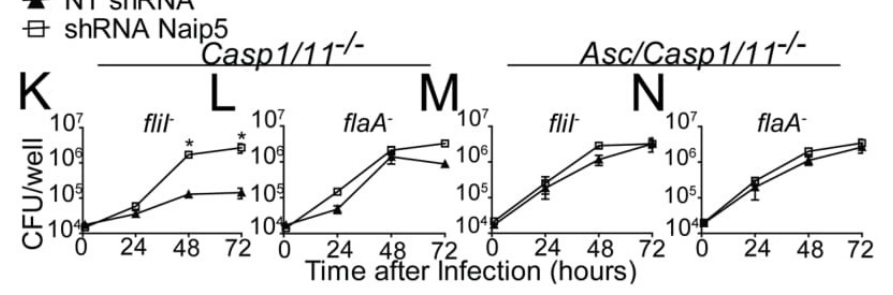

Fig 8. Naip5 is required for the functions of the NLRC4/ASC/Caspase-8 inflammasome independently of caspase-1/11. Bone marrow-derived macrophages (BMDMs) generated from Casp1/11\% and Asc/Casp1/ $11^{-\%}$ mice were transduced with a retrovirus encoding shRNA sequence to target Naip5 and a non-target shRNA sequence (NT). Transduced BMDMs were infected with wild-type L. pneumophila (WT Lp), motilitydeficient mutants expressing flagellin ( $f l i r)$ or with flagellin-deficient mutants ( $f l a A^{-}$) at a MOI of 10 . (A) 8 hours after infection the activity of caspase- 8 was measured using the Caspase-8 Glo Assay. (B) Quantification of the Naip5 gene expression by Real Time qPCR. Gapdh gene was used as a control for normalization of expression levels. The number above the bars indicates the percentage of silencing compared to the NT shRNA (open bars). (C-J) Pore formation was assessed fluorometrically in real time by the uptake of propidium iodide. The RFU (\%) represents the percentage of RFU estimated with cells lysed with Triton X100. (K-N) The cells were infected with flit or flaA for 24,48 and 72 hours for CFU determination. Data show the average \pm SD of triplicate wells. ${ }^{*}, P<0.05$, Student's t test (A) and ANOVA (K-N). NS, not significant; RFU, relative fluorescence units; $\mathrm{NI}$, uninfected. Data are presented for one representative experiment of two (A-J) and three (K-N) experiments with similar results.

https://doi.org/10.1371/journal.ppat.1006502.g008

data indicates that Naip5 participate of the NLRC4/ASC inflammasome that trigger caspase-8 activation in the absence of caspase-1/11.

Caspase- 8 is recruited to the NLRC4/ASC/caspase- 1 inflammasome but it is only activated when caspase-1 or gasdermin-D is suppressed

In the experiments shown thus far, we used Casp $1 / 11^{-/}$macrophage as a tool to assess the caspase- 8 effects without the interference of caspase- 1 . However, because caspase- 1 is present in natural conditions, we tested if caspase-8 participates in the NLRC4/ASC inflammasome in 
the presence of caspase-1. First, we infected C57BL/6 macrophages with flagellin-positive $L$. pneumophila to assess if endogenous caspase- 8 colocalizes with the Naip5/NLRC4/ASC inflammasome. In uninfected conditions, we detected no significant puncta formation (Fig 9A). However, in response to fliT bacteria, caspase- 8 colocalizes with ASC (Fig 9B) and caspase-1 (Fig 9C). We determined that caspase- 8 is present in more than $60 \%$ puncta containing caspase-1 (Fig 9C). These data indicates that regardless to the presence of caspase-1, the caspase- 8 is recruited to the inflammasome during activation.

Next, we evaluated caspase- 8 activation in wild-type macrophages. We found that caspase- 8 activation does not occur in C57BL/6 macrophages infected with L. pneumophila. As expected caspase-8 is readily activated in Casp $1 / 11^{-/}$, but not in Asc/Casp $1 / 11^{-/}$macrophages infected with fliI bacteria (Fig 9D). To ensure similar genetic background, we intercrossed a F1 progeny of Casp $1 / 11^{-1}$ x C57BL/6 to obtain F2 littermate controls. Infections in macrophages from littermate control mice indicated that caspase- 8 activation occur in Casp $1 / 11^{-/-}$, but not in Casp $1 / 11^{+/-}$and Casp $1 / 11^{+/+}$macrophages (Fig 9E). To further test whether the deficiency in caspase- 1 or caspase- 11 enable caspase- 8 activation, we performed experiments using mice single deficient in caspase- 1 or caspase- 11 as previously described $[35,66]$. We found that caspase-11 deficiency alone is not sufficient to enable caspase-8 activation in response to L. pneumophila infection (Fig 9F). In contrast, caspase-1-deficient cells expressing caspase-11 as a transgene $\left(\mathrm{Casp}^{-/} \mathrm{Casp}_{11^{\mathrm{tg}}}\right)$ effectively trigger caspase-8 activation in response to fliT L. pneumophila (Fig 9F). These data indicate that caspase-1 but not caspase-11 is required to prevent caspase-8 activation.

Caspase-1 activation via the NLRC4 inflammasome is known to trigger activation of gasdermin-D (GSDMD) to induce cell death $[67,68]$. Thus, we tested if inhibition of GSDMD is sufficient to enable caspase- 8 activation in the presence of caspase- 1 . To achieve this, we inhibited endogenous GSDMD using shRNA and found that despite the presence of caspase-1, caspase- 8 is robustly activated when GSDMD is inhibited (Fig 9G). RT-PCR was used to confirm the silencing of the two different sequences of shRNA used (Fig 9H). To further confirm the GSDMD silencing, we performed pore formation assay in C57BL/6 macrophages infected with L. pneumophila. We found that GSDMD silencing inhibited the caspase-1-mediated pore formation induced by WT Lp and fliT L. pneumophila (S11A-S11D Fig). However, GSDMD did not participate of pore formation induced via caspase- 8 that occurs in Casp $1 / 11^{-/-}$macrophages (S11E-S11H Fig). Collectively, these data indicates that despite the presence of caspase-1, caspase- 8 activation occur in the Naip5/NLRC4/ASC inflammasome when GSDMD is inhibited.

\section{Discussion}

The recognition of Legionella flagellin by the Naip5/NLRC4 inflammasome in macrophages is a major mechanism for the restriction of bacterial replication in mouse cells $[17-20,22,69,70]$. It is well accepted in the field that not all NLRC4 functions require caspase-1 [29,38,71,72]. This conclusion is supported by the observation that $\mathrm{Nlrc}^{-/-}$mice (and their macrophages) are significantly more permissive to L. pneumophila replication than Casp $1 / 11^{-/}$mice $[29,38]$. Here, we unraveled this caspase-1/11-independent pathway and characterized an inflammasome composed of Naip5, NLRC4, ASC and caspase-8, which operates in the absence of caspase- 1 and caspase-11. This inflammasome effectively participates in the mechanisms involved in the restriction of bacterial replication in macrophages and in vivo. Previous biochemistry studies using yeast two-hybrid screening showed that NLRC4 is ubiquitinated by Sug1, a process that facilitates the activation of caspase-8 [51]. Thus, it is possible that Sug1 is also a component of this NLRC4 inflammasome. In addition, previous studies using the Salmonella 

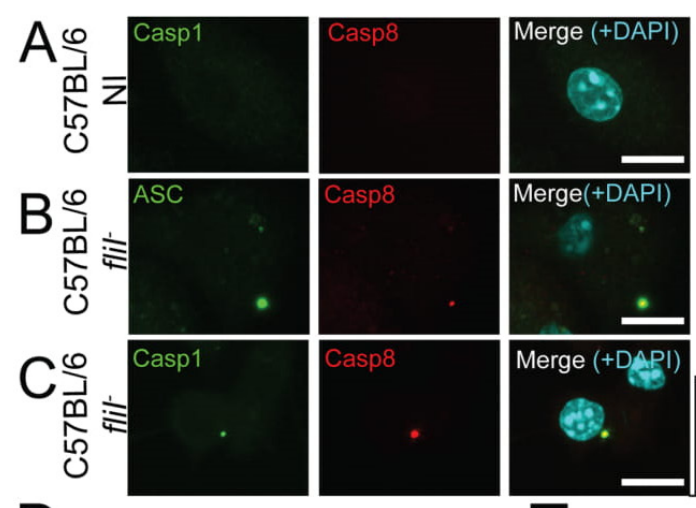

$\mathrm{D}$
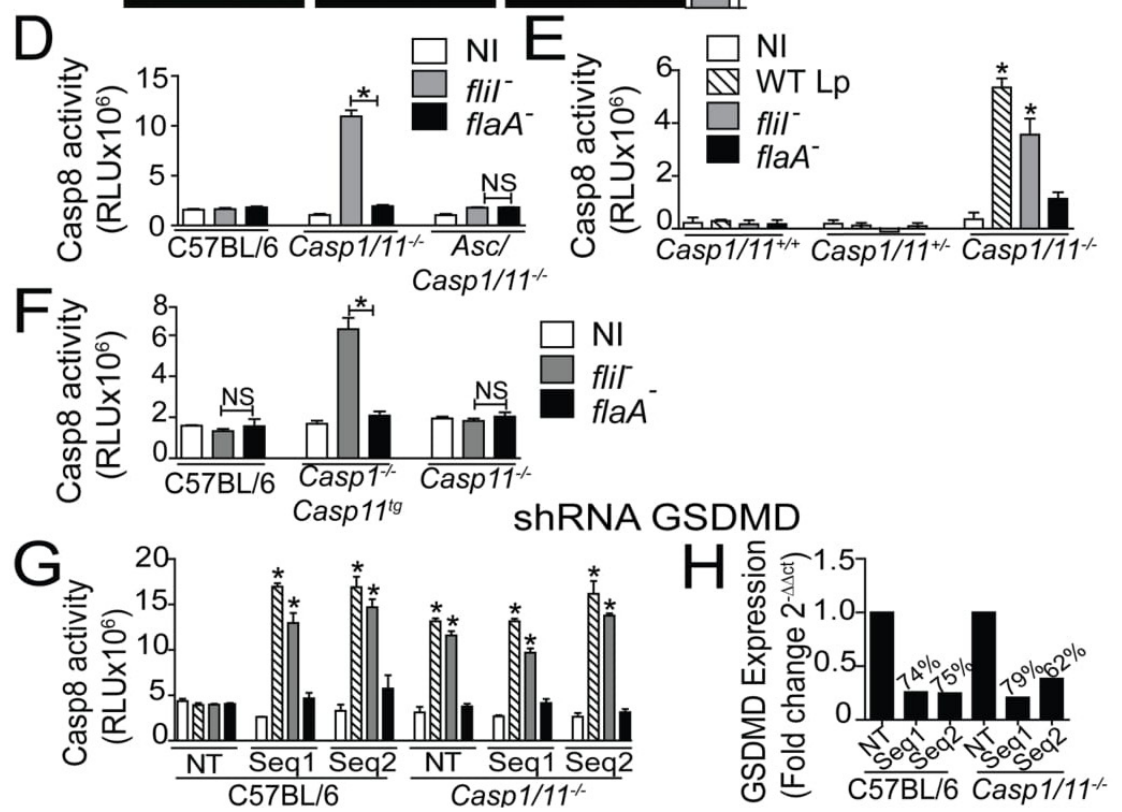

Fig 9. Caspase-8 colocalizes with the NLRC4/ASC/Caspase-1 inflammasome, but it is only activated if caspase-1 or gasdermin-D is inhibited. (A-C) Bone marrow-derived macrophages (BMDMs) generated from C57BL/6 mice were infected with motility-deficient $L$. pneumophila mutants expressing flagellin (flir) at a $\mathrm{MOI}$ of 10 for $8 \mathrm{~h}$. The cultures were stained with anti-caspase- 1 (green) (A, C) or anti-ASC (green) (B), anticaspase-8 (red). Cell nuclei were stained with DAPI (cyan). Images were acquired by multiphoton microscopy with a $63 x$ oil immersion objective and analyzed using ImageJ software. The images are the maximal projection of a z project. Scale bars, $10 \mu \mathrm{m}$. (C) The percentage of the caspase-1 puncta containing caspase- 8 was determined using an epifluorescence microscope. (D) BMDMs were generated from C57BL/6, Casp1/ $11^{\%}$ and $A s c / C a s p 1 / 11^{\%}$ mice and infected with flit or flaA. (E) BMDMs were generated from Casp 1/11 $1^{+/+}$ Casp $1 / 11^{+/-}$and Casp $1 / 11^{-/}$littermate control mice and infected with WT, flir and flaA'. (F) BMDMs were generated from C57BL/6, Casp $1^{-/}$Casp $11^{\text {tg }}$ and Casp $11^{-/}$mice and infected with WT, flir and flaA- (G-H) BMDMs generated from C57BL/6 and Casp $1 / 11^{-/}$mice were transduced with a retrovirus encoding shRNA sequences to target Gasdermin D (GSDMD) (Seq1, Seq2) and a non-target shRNA sequence (NT). (G) Transduced cells were infected with WT Lp, flir and fla $A^{-}$. (D-G) Cells were infected with an MOI of 10 and after 8 hours the activity of caspase- 8 was measured using the Caspase- 8 Glo Assay. (H) GSDMD silencing was confirmed by Real Time qPCR. Gapdh gene was used as a control for normalization of expression levels. The numbers above the bars indicate the percentage of silencing compared to the NT sequence. Data show the average \pm SD of triplicate wells. * $P<0.05$, Student's t test in relation to fla $A^{*}$. RLU, relative luminescence units; $\mathrm{NI}$, non-infected. Data are presented for one representative experiment of two $(\mathrm{A}-\mathrm{C}$ and $\mathrm{E}-\mathrm{H})$ and five (D) experiments with similar results.

https://doi.org/10.1371/journal.ppat.1006502.g009 
enterica serovar Typhimurium have indicated that both caspase- 8 and caspase- 1 are recruited to the ASC puncta in response to infection. However, caspase- 8 is involved in the synthesis of pro-IL-1 $\beta$ and is dispensable for Salmonella-induced cell death [32]. These data contrast with published data using L. pneumophila, which indicate that in the absence of caspase-1/11, no inflammatory cytokines are produced $[20,21,25,30,35,66]$. Accordingly, our data indicates that this Naip5/NLRC4/ASC/Caspase-8 inflammasome is very inefficient to trigger IL-1 $\beta$ maturation when caspase-1 is not present.

Importantly, AIM2 is not part of this NLRC4/ASC/caspase- 8 inflammasome. AIM2 is wellknown to trigger caspase- 8 activation via ASC $[33,34,58]$. Our data unequivocally demonstrate that AIM2 is neither a component of this inflammasome, nor is it required for inflammasome functions. AIM2 did not colocalize with the NLRC4/ASC/caspase-8 puncta, it was dispensable for the activation of caspase- 8 in response to flagellated L. pneumophila and for the induction of cell death and restriction of L. pneumophila replication. The pyrin domain of ASC can bind to the death domain of caspase- 8 [46]. Thus, it is possible that the interactions of the ASC pyrin domain with the caspase- 8 dead domain are critical for the recruitment of caspase- 8 to the complex. Consistent with this hypothesis, our studies unequivocally show that ASC is required for the assembly and function of this NLRC4 inflammasome. Importantly, the characterization of this NLRC4/ASC/caspase-8 inflammasome accounted to clarify a controversy in the field concerning the participation of ASC in the NLRC4 inflammasome. Studies utilizing biochemistry and cells from gene-deficient mice have demonstrated that ASC is dispensable for NLRC4 functions, including pyroptosis and the restriction of L. pneumophila replication $[20,21,29]$. However, ASC is essential for caspase- 1 cleavage and the processing of inflammatory cytokines in response to flagellated L. pneumophila, a process that is NLRC4-dependent and NLRP3-independent $[20,21,25,30]$. In addition, ASC participates in the restriction of intracellular replication of $L$. pneumophila under certain circumstances [36,37]. Our studies provide data that help to consolidate these data in a cohesive model. NLRC4 can operate to form an inflammasome in absence of ASC that triggers pore formation and the restriction of bacterial replication $[20,21,25,30]$. This platform does not form puncta and is ineffective for triggering caspase-1 cleavage and processing inflammatory cytokines. When ASC is present, NLRC4 inflammasome associates with ASC and recruit caspase- 1 and caspase- 8 to the puncta. This inflammasome is very efficient to cleave caspase- 1 and inflammatory cytokines such as IL-1 $\beta$. Interestingly, our data indicate that caspase- 8 is not activated when caspase- 1 is present. However, when caspase-1 is missing or when Gasdermin-D is inhibited, we detected a robust caspase- 8 activation. These data suggest that activation of caspase- 8 in the Naip5/NLRC4/ASC inflammasome functions as a backup strategy to guarantee cell death when key components of the pyroptotic cell death are inhibited. Interestingly, our data and previously published data indicate that gasdermin-D is dispensable for caspase-8-induced cell death [73]. Therefore, when gasdermin- $\mathrm{D}$ is inhibited, caspase- 8 engages gasdermin- $\mathrm{D}$-independent cell death. It is possible that caspase- 8 induces caspase- 3 and caspase- 7 to targed gasdermin-E (also known as DFNA5) to induce pore formation and cell death independent of gasdermin-D [74,75]. This may guarantee appropriate responses to pathogens that inhibit canonical components of pyroptotic cell death such as caspase-1 or gasdermin-D.

\section{Materials and methods}

\section{Bacterial culture}

The L. pneumophila bacteria used were JR32 and isogenic clean deletion mutants for motility (fli $)$ and flagellin (flaA ${ }^{-}$) [19,38]. L. micdadei (ATCC 33218) and L. gratiana (ATCC 49413) were used to generate streptomycin-resistant strains. RpsL mutants of $L$. micdadei and $L$. 
gratiana were isolated by plating these strains on CYE agar containing $100 \mu \mathrm{g} / \mathrm{ml}$ of streptomycin. All bacteria were grown on buffered charcoal-yeast extract (CYE) agar plates [1\% yeast extract, $1 \%$ MOPS, $3.3 \mathrm{mM}$ L-cysteine, $0.33 \mathrm{mM} \mathrm{Fe}(\mathrm{NO} 3) 3,1.5 \%$ Bacto agar and $0.2 \%$ activated charcoal, $\mathrm{pH}$ 6.9] [76].

\section{Macrophages}

Bone Marrow derived macrophages (BMDMs) were generated from mice as previously described [77]. Briefly, bone marrow cells were harvested from femurs and differentiated with RPMI 1640 (Gibco) containing 20\% fetal bovine serum (FBS-Invitrogen) and 30\% L-929 cell-conditioned medium (LCCM), 2 mM L-glutamine (Sigma-Aldrich), $15 \mathrm{mM}$ Hepes (Gibco) and $100 \mathrm{U} / \mathrm{ml}$ penicillin-streptomycin (Sigma-Aldrich) at $37^{\circ} \mathrm{C}$ with $5 \% \mathrm{CO}_{2}$ [77]. BMDMs were seeded at $2 \times 10^{5}$ cells/well in 24-well plates and cultivated in RPMI 1640 medium (Gibco) supplemented with 10\% FBS, 5\% LCCM, 2 mM L-glutamine and $15 \mathrm{mM}$ Hepes.

\section{In vitro infections and CFU determination}

For the in vitro infections, the cultures were infected at a multiplicity of infection of $0.015,5$ or 10 followed by centrifugation for 5 minutes at $300 \mathrm{Xg}$ at room temperature and incubation at $37^{\circ} \mathrm{C}$ in a $5 \% \mathrm{CO}_{2}$ atmosphere. In the colony-forming units (CFU) experiments, cultures infected at a MOI of 10 were washed two times with PBS, and $1 \mathrm{ml}$ of medium was added to each well. For CFU determination, the cultures were lysed in sterile water, and the cell lysates were combined with the cell culture supernatant from the respective wells. Lysates plus supernatants from each well were diluted in water, plated on CYE agar plates, and incubated for 4 days at $37^{\circ} \mathrm{C}$ for $\mathrm{CFU}$ determination as described previously $[28,38]$.

\section{Retroviral transduction and quantification of NLRC4-GFP and ASC-GFP puncta}

Murine Nlrc4 or Asc were cloned into the pEGFP (N2) vector (Clontech) using XhoI and BamHI restriction sites as previously described [30]. NLRC4-GFP or ASC-GFP and GFP were cloned into the pMSCV2.2 murine-specific retroviral vector (Clontech). The pCL vector system 51 was used to package the retroviruses in transfected monolayers of Hek Peak cells (ATCC CRL-2828), which were maintained in RPMI with 10\% FBS. The supernatant from the Hek Peak cells containing retrovirus was collected three days after transfection, filtered using a $0.45-\mu \mathrm{m}$ filter and used for BMDM transduction. BMDMs were obtained from Casp $1 / 11^{-1}$, Asc/Casp $1 / 11^{-1-}$ and Aim2/Casp $1 / 11^{-1-}$ mice and seeded in differentiation medium. On day 3 of differentiation, the supernatants containing retroviral were added to BMDMs in $20 \%$ FBS and $25 \%$ LCCM. After differentiation, the BMDMs were seeded at $2 \times 10^{5}$ cells/well in 24-well plates containing 12-mm glass cover slides and cultivated in RPMI 1640 medium supplemented with 10\% FBS and 5\% LCCM. For the caspase colocalization experiments, the cultures were treated with $20 \mu \mathrm{m}$ of Z-VAD for 1 hour and infected at a MOI of 1,3 or 10. After infection, the plates were centrifuged for 5 minutes at $300 \mathrm{X} g$ at room temperature and incubated at $37^{\circ} \mathrm{C}$ in a $5 \% \mathrm{CO}_{2}$ atmosphere. At $1,2,4$ and 8 hours after infection, the cells were fixed with $4 \%$ paraformaldehyde, permeabilized with $0.05 \%$ saponin, stained with DAPI and mounted on glass slides using Prolong Gold Antifade Reagent (Invitrogen). For the colocalization assay, the cells were stained with rat anti-caspase-8 (Enzo- 1G12; 1:50), rabbit anti-cleaved caspase-8 (Cell signaling- 8592; 1:800), rabbit anti-cleaved caspase-3 (Cell signaling- 9664; 1:400); rabbit anti-cleaved caspase-7 (Cell signaling-8438; 1:400), anti-ASC (Adipogen- AL177; 1:250), goat anti-ASC (Santa Cruz-sc33958; 1:50), rabbit anti-caspase-1 (Santa Cruz- sc514; 
1:500) or anti-AIM2 (Cell signaling- 13095; 1:400), followed by Alexa 594-conjugated goat anti-rabbit secondary $\mathrm{Ab}$ (Invitrogen; 1:3000), Alexa 594-conjugated goat anti-rat secondary $\mathrm{Ab}$ (Invitrogen; 1:3000) or Alexa 647-conjugated chicken anti-rabbit secondary Ab (Invitrogen; 1:2000) and DAPI and mounted on glass slides using Prolong Gold Antifade Reagent (Invitrogen). The images were processed using LAS AF software (Leica Microsystems) and analyzed under fluorescence using a Leica DMI 4000B inverted microscope with a 100X oil objective. The number of NLRC4-GFP or ASC-GFP puncta in the transduced cells and the colocalization were quantified. Bacteria were not stained. Therefore, the whole cell population was scored. Multiphoton microscopy images were acquired using an LSM 780 Zeiss AxioObserver microscope equipped with a $63 \mathrm{X}$ oil immersion objective and analyzed using ImageJ software.

\section{Retroviral silencing of caspase-8, Naip5 and GSDMD}

For retroviral silencing of caspase-8, Naip5 and GSDMD (Gasdermin D), Hek Peak cells were transfected with lentiviral vectors encoding a small hairpin RNA (shRNA) targeting caspase-8 [Sigma- Seq1: TRCN0000231279 (Sequence- CCGGTCATCTCACAAGAACTATATTCTCG AGAATATAGTTCTTGTGAGATGATTTTTG); Seq2: TRCN0000231281 (Sequence-CCGG TCCTGACTGGCGTGAACTATGCTCGAGCATAGTTCACGCCAGTCAGGATTTTTG)], Naip5 [Sigma- TRCN0000114742 (Sequence-CCGGCGCTTGATTATCTTCTGGAAACT CGAGTTTCCAGAAGATAATCAAGCGTTTTTG)], GSDMD [Sigma- TRCN0000219619 (Sequence-CCGGGATTGATGAGGAGGAATTAATCTCGAGATTAATTCCTCCTCATC AATCTTTTTG); TRCN0000219620 (Sequence-CCGGCCTAAGGCTGCAGGTAGAATC CTCGAGGATTCTACCTGCAGCCTTAGGTTTTTG)] and a negative control vector that included a non-target shRNA sequence (NT). The plates were treated with polyethylenimine (Sigma-Aldrich) (Corning). Transduced cells were maintained in RPMI 1640 medium supplemented with $10 \% \mathrm{FBS}$ at $37^{\circ} \mathrm{C}$ and $5 \% \mathrm{CO}_{2}$. Lentiviruses expressing shRNAs were collected, filtered using a $0.45-\mu \mathrm{m}$ filter and added to the BMDMs. After selection with puromycin, the resistant cells were seeded at $2 \times 10^{5}$ cells/well in 24 -well plates and infected with fli $\mathrm{I}_{\text {or }} \mathrm{flaA}^{-}$ for $\mathrm{CFU}$ determination. The caspase- 8 silencing efficiency was measured by immunoblotting: 1 X $10^{6}$ cells were lysed in RIPA buffer (10 mM Tris-HCl, pH 7.4, 1 mM EDTA, $150 \mathrm{mM}$ $\mathrm{NaCl}, 1 \%$ Nonidet P- $40,1 \%$ deoxycholate, and $0.1 \%$ SDS) in the presence of a protease inhibitor cocktail (Roche). The lysates were suspended in $4 \mathrm{X}$ Laemmli buffer, boiled for 5 minutes, resolved by $15 \%$ SDS PAGE and transferred (Semidry Transfer Cell, Bio-Rad) to $0.22-\mu \mathrm{m}$ nitrocellulose membranes (GE Healthcare). The membranes were blocked in Tris-buffered saline (TBS) with $0.01 \%$ Tween- 20 and 5\% non-fat dry milk for 1 hour. Rat anti-caspase-8 p55 (Enzo-1G12; 1:500) and anti-rat peroxidase-conjugated antibody (KPL, 1:3000) were diluted in blocking buffer for the incubations (overnight for anti-caspase- 8 and 1 hour for the secondary antibody). The ECL luminol reagent (GE Healthcare) was used for antibody detection. For evaluation of caspase- 8 silencing by immunoblots, Image J software were used to estimate the ratio of caspase- 8 p 55 to $\alpha$-actin.

\section{Caspase-8 activation}

To assess caspase- 8 activation, BMDMs were infected with fliI or $f l a A^{-}$for 8 hours, and the activity of caspase- 8 was measured using the Caspase- 8 Glo Assay (Promega) according to manufacturer's recommendations. To evaluate caspase- 8 activation by western blot analysis, 1 X $10^{7}$ cells were infected at a MOI of 10 and lysed 8 hours after infection in RIPA buffer with protease inhibitor, as previously described. The lysates were suspended in 4X Laemmli buffer, boiled for 5 minutes, resolved by $15 \%$ SDS PAGE and transferred to $0.22-\mu \mathrm{m}$ nitrocellulose 
membranes. The membranes were blocked in Tris-buffered saline (TBS) with $0.01 \%$ Tween20 and $5 \%$ non-fat dry milk or for 1 hour. The mouse anti-caspase- 8 (Enzo- 1G12) and antirabbit peroxidase-conjugated antibody (KPL; 1:3000) were diluted in blocking buffer for the incubations (overnight for anti-cleaved caspase- 8 and 1 hour for the secondary antibody). ECL luminol reagent (GE Healthcare) was used for antibody detection.

\section{Real Time q-PCR}

Total RNA was extracted from $2 \times 10^{6}$ macrophages using total RNA isolation kit (illustra RNAspin, GE Healthcare, UK), according to manufacturer's instructions. After extraction, an aliquot of $2 \mu \mathrm{l}$ was used to determine the RNA concentration in NanoDrop (Thermo Fisher Scientific) and $1 \mu \mathrm{g}$ of the extracted RNA was used for the cDNA conversion using the iScriptTM cDNA Synthesis kit (BIO-RAD) in a thermal cycler. The cDNA (10 ng) was used for the quantification of the Caspase 8 gene expression (TaqMan Assay: Casp 8-Mm01255716_m1) by realtime PCR using TaqMan Fast Advanced Master Mix, according to the manufacturer's instruction (Applied Biosystems). Actin beta (Actb) gene (TaqMan Assay: Actb-Mm00607939_s1) was used as a control for normalization of expression levels. The quantification of GSDMD and Naip5 were performed using $25 \mathrm{ng}$ of cDNA and $10 \mu \mathrm{M}$ of each primer, $1 \mathrm{X}$ SYBR Green (Applied Biosystems), and was normalized using the housekeeping gene glyceraldehyde-3phosphate dehydrogenase (Gapdh). The specificity of the PCR products was assessed by melting curve analysis for all samples. The following primers were used: Gapdh, FWD- AGGTCGGTG TGAACGGATTTG, REV-TGTAGACCATGTAGTTGAGGTCA, GSDMD, FWD-TCATGT GTCAACCTGTCAATCAAGGACAT, REV- CATCGACGACATCAGAGACTTTGAAGGA, NAIP5, FWD- GTTGAGATTGGAGAAGACCTCG, REV-CACACGTGAAAGCAACCATGG. The real-time quantitative reaction was performed in the Viia 7 Real-Time PCR System (Applied Biosystems). The results were analyzed using the $2^{-\Delta \Lambda C T}$ method and are expressed in relation to the reference group. The percentage of silencing knockdown was estimated using the $\left[1-\left(2^{-\Delta \mathrm{CCT}}\right)\right.$ $\mathrm{x}$ 100] equation [78].

\section{Mice and in vivo infections}

Mice used in this study were breed and maintained in institutional animal facilities. Mice used

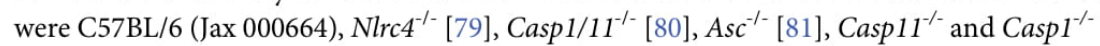
Casp $11^{\text {tg }}[66]$ were. Double-deficient mice were generated by intercrossing a F1 progeny of the parental strains. All mice were matched by sex and age (all were at least 8 weeks old at the time of infection) and were in a C57BL/6 mouse genetic background. For the in vivo experiments, approximately 5-7 mice per group were used, as indicated in the figures. For in vivo infections, the mice were anesthetized with ketamine and xylazine $(50 \mathrm{mg} / \mathrm{kg}$ and $10 \mathrm{mg} / \mathrm{kg}$, respectively) by intraperitoneal injection followed by intranasal inoculation with $40 \mu \mathrm{l}$ of phosphate-buffered saline (PBS) containing $1 \times 10^{5}$ bacteria per mouse. For CFU determination, the lungs were harvested and homogenized in $5 \mathrm{ml}$ of sterile water for 30 seconds using a tissue homogenizer (Power Gen 125; Thermo Scientific). Lung homogenates were diluted in sterile water and plated on CYE agar plates for CFU determination as previously described [28,38].

\section{Pore formation assay}

Pore formation in BMDMs was quantified based on the permeability to propidium iodide (PI) in damaged cells as previously described [61]. BMDMs were seeded in a black, clear-bottom 96-well plate ( 1 X $10^{5}$ cells/well). Before infection, the medium was replaced with $10 \%$ RPMI without phenol red, $0.038 \mathrm{~g} / \mathrm{ml} \mathrm{NaHCO}, 6 \mu \mathrm{l} / \mathrm{ml} \mathrm{PI}$ and anti-L. pneumophila (1:1000). Infected BMDMs were maintained at $37^{\circ} \mathrm{C}$, and PI was excited at $538 \mathrm{~nm}$. The fluorescence 
emission was read at $617 \mathrm{~nm}$ every 5 minutes using a plate fluorometer (SpectraMax i3x, Molecular Devices). Total pore formation was determined by lysing cells with Triton X-100.

\section{Lactate dehydrogenase release assay and ELISA}

BMDMs were seeded in 24-well plates ( $5 \times 10^{5}$ cells/well). Infections were performed in RPMI1640 medium without phenol red, $15 \mathrm{mM} \mathrm{HEPES}$ and $2 \mathrm{~g} / \mathrm{l} \mathrm{NaHCO}_{3}$ supplemented with $10 \%$ FBS. After 8 hours of infection, the supernatants were collected for analysis of lactate dehydrogenase (LDH) release. Total LDH was determined by lysing the cultures with Triton $\mathrm{X}-100$. LDH was quantified using the CytoTox $96 \mathrm{LDH}-$ release kit (Promega). For cytokine determination, enzyme-linked immunosorbent assay (ELISA) were used. BMDMs were seeded into 24 -well plates ( $5 \times 10^{5}$ cells/well) and infected with WT Lp, fliT and flaA- (MOI 10) for 24 hours. BMDMs supernatant was assessed using ELISA kits according to manufacturer's recommendations (BD Biosciences).

\section{Ethics statement}

The care of the mice was in compliance with the institutional guidelines on ethics in animal experiments; approved by CETEA (Comissão de Ética em Experimentação Animal da Faculdade de Medicina de Ribeirão Preto, approved protocol number 218/2014). CETEA follow the Brazilian national guidelines recommended by CONCEA (Conselho Nacional de Controle em Experimentação o Animal). For euthanasia, the mice were treated with ketamine and xylazine (50 $\mathrm{mg} / \mathrm{kg}$ and $10 \mathrm{mg} / \mathrm{kg}$, respectively) by intravenous injection.

\section{Statistical analysis}

The data were plotted and analyzed using GraphPad Prism 5.0 software. The statistical significance was calculated using the Student's t-test or analysis of variance (ANOVA). Nonparametric test Mann-Whitney U test were used for analysis of in vivo experiments. Differences were considered statistically significant when $P$ was $<0.05$, as indicated by an asterisk in the figures.

\section{Supporting information}

S1 Fig. Restriction of $L$. pneumophila replication is fully dependent on NLRC4 and flagellin, and partially dependent on caspase-1/11. Bone marrow-derived macrophages (BMDMs) from C57BL/6 (open circles), Nlrc4 ${ }^{-/-}$(closed squares), Casp1/11 $1^{-/}$(closed triangles) and Asc ${ }^{-/}$ (open inverted triangles) mice were infected with L. pneumophila for CFU determination. (A, B) Cells were infected with wild-type L. pneumophila (WT Lp). (C, D) Cells were infected with motility-deficient mutants expressing flagellin $(f l i T)$. (E, F) Cells were infected with flagellindeficient mutants $\left(f l a A^{-}\right)$. BMDMs were infected with $3 \times 10^{3}$ (MOI 0.015 ) or $2 \times 10^{5}$ (MOI 10) bacteria per well and incubated for $24,48,72$ and 96 hours for CFU determination. Data show the average \pm SD of triplicate wells. ${ }^{*}, P<0.05$ compared with Casp $1 / 11^{-/-}$BMDMs, ANOVA. Data are presented for one representative experiment of two experiments with similar results. (TIF)

S2 Fig. Caspase- 8 but not caspase-3 and caspase-7 colocalize with NLRC4-GFP and ASC-GFP puncta. Bone marrow-derived macrophages (BMDMs) generated from Casp $1 / 11^{-1}$ mice were transduced with retrovirus encoding NLRC4-GFP (A) or ASC-GFP (B) and infected with motility-deficient $L$. pneumophila mutants expressing flagellin (fliI) at a MOI of 10 for $8 \mathrm{~h}$. (A-B) The percentage of colocalization of caspase-3, caspase- 7 and caspase- 8 with NLRC4-GFP and ASC-GFP was determined using an epifluorescence microscope. (C-E) BMDMs generated from Casp $1 / 11^{-/-}$mice were infected with fliI at a MOI of 10 for $8 \mathrm{~h}$. The 
cultures were fixed and stained with anti-ASC (green), anti-caspase-3 (red) (C), anti-caspase-7 (red) (D), anti-caspase-8 (red) (E). Cell nuclei were stained with DAPI (cyan). Images were acquired by multiphoton microscopy with a $63 \mathrm{x}$ oil immersion objective and analyzed using ImageJ software. The images are the maximal projection of a z project. Scale bar, $10 \mu \mathrm{m}$. Data show the average \pm SD of triplicate wells. ${ }^{*}, P<0.05$, Student's $t$ test. Data are presented for one representative experiment of two experiments with similar results. (TIF)

S3 Fig. AIM2 does not colocalize and is not required for NLRC4-GFP puncta formation. Bone marrow-derived macrophages (BMDMs) generated from Casp $1 / 11^{-/-}$and Aim $2 / C a s p 1 /$ $11^{-/}$mice were transduced with retrovirus encoding NLRC4-GFP and infected with wild-type L. pneumophila (WT) or with motility-deficient $L$. pneumophila mutants expressing flagellin $(f l i I)$ at a MOI of 10 for $8 \mathrm{~h}$. (A) The cultures were stained with anti-AIM2 (red), the cell nuclei were stained with DAPI (cyan) and the NLRC4-GFP puncta is shown in green. The percentage of colocalization of AIM2 with NLRC4-GFP is shown. Images were acquired by multiphoton microscopy with a $63 x$ oil immersion objective and analyzed using ImageJ software. Scale bar, $10 \mu \mathrm{m}$. (B) Quantification of the number of transduced cells containing NLRC4-GFP in response to WT or fli infection was estimated in Casp $1 / 11^{-/-}$and Aim2/Casp $1 / 11^{-/-}$BMDMs. Data show the average \pm SD of triplicate wells. NS, not significant, Student's t test. NI, uninfected. Data are presented for one representative experiment of two experiments with similar results. (TIF)

S4 Fig. AIM2 is not required for caspase-8 activation in response to flagellated L. pneumophila. Bone marrow-derived macrophages (BMDMs) generated from Casp $1 / 11^{-/}$and Aim2/ Casp $1 / 11^{-1-}$ mice were infected with motility-deficient L. pneumophila mutants expressing flagellin $(f l i I)$ or with flagellin-deficient bacteria $\left(f l a A^{-}\right)$at a MOI of 10 for 8 hours. The activity of caspase- 8 was measured using the Caspase- 8 Glo Assay. Data show the average \pm SD of triplicate wells. ${ }^{*}, P<0.05$, Student's t test. NI, uninfected. Data are presented for one representative experiment of two experiments with similar results.

S5 Fig. Caspase-8 quantification in the western blot shown in Fig 4A. Bone marrow-derived macrophages (BMDMs) generated from Casp $1 / 11^{-1}$ mice were transduced with a retrovirus encoding shRNA sequences to target caspase-8 (Seq1, Seq2) and a non-target shRNA sequence (NT). The silencing was confirmed by western blot analysis (Fig 4A). Cell lysates were separated by SDS-PAGE, blotted and probed with anti-caspase- 8 (pro-caspase- 8 p55) and anti- $\alpha$-actin. Immunoblots were analyzed in Image J software and the caspase- 8 p 55 to $\alpha$-actin ratio is shown. (TIF)

S6 Fig. AIM2 is not required for NLRC4-mediated restriction of L.pneumophila replication in macrophages. Bone marrow-derived macrophages (BMDMs) from C57BL/6, Nlrc4 ${ }^{-/}$, Casp $1 / 11^{-/}$and Aim $2 / C a s p 1 / 11^{-/}$mice were infected with motility-deficient L. pneumophila mutants expressing flagellin (fliI) at a MOI of 0.015 . The cultures were incubated for $24,48,72$ and 96 hours after infection for CFU determination. Data show the averages \pm SD of triplicate wells. ${ }^{*}, P<0.05$, compared with Casp $1 / 11^{-/}$cells. Student's t test. Data are presented for one representative experiment of three experiments with similar results.

S7 Fig. Caspase-8 quantification in the western blot shown in Fig 5E. Bone marrow-derived macrophages (BMDMs) generated from Casp $1 / 11^{-/}$and Asc/Casp $1 / 11^{-/-}$mice were transduced with a retrovirus encoding shRNA sequences to target caspase-8 (Seq1, Seq2) and a non-target 
shRNA sequence (NT). The silencing was confirmed by western blot analysis (Fig 5E). Cell lysates were separated by SDS-PAGE, blotted and probed with anti-caspase- 8 (pro-caspase- 8 p55) and anti- $\alpha$-actin. Immunoblots were analyzed in Image J software and the caspase- 8 p 55 to $\alpha$-actin ratio is shown.

(TIF)

S8 Fig. AIM2 is not required for NLRC4-mediated restriction of L. pneumophila infection in vivo. $\mathrm{C} 57 \mathrm{BL} / 6$ (open circles), $\mathrm{Nlrc}^{-/-}$(closed squares), Casp1/11 $1^{-1-}$ (closed triangles), Aim $2 /$ Casp $1 / 11^{-/-}$(open diamond) and Asc/Casp $1 / 11^{1-}$ (closed triangles) mice were infected intranasally with $1 \times 10^{5}$ motility-deficient $L$. pneumophila mutants expressing flagellin $(f l i T)$. The mice were euthanatized at 4 and 48 hours after infection. Dilutions of the lung homogenates were added to charcoal-yeast extract agar plates for colony-forming unit determination. Each dot represents a single animal, and the horizontal lines represent averages. ${ }^{*}, P<0.05$, Student's $t$ test. NS, not significant.

(TIF)

S9 Fig. The NLRC4/ASC/caspase-8 inflammasome is important for pore formation and cell death independently of caspase-1/11. Bone marrow-derived macrophages (BMDMs) were generated from C57BL/6, Casp $1 / 11^{-/}$and Asc/Casp $1 / 11^{-/-}$mice and infected with motility-deficient $L$. pneumophila mutants expressing flagellin $(f l i I)$ or with flagellin-deficient bacteria $\left(f l a A^{-}\right)$ at a MOI of 10. (A-C) Pore formation was assessed fluorometrically in real time by the uptake of propidium iodide. RFU (\%) represents the percentage of RFU estimated with cells lysed with Triton X-100. (D) After 8 hours the LDH release was measured using the CytoTox 96 LDHrelease kit. The $\mathrm{LDH}$ release (\%) represents the percentage of $\mathrm{LDH}$ released compared with cells lysed with Triton $\mathrm{X}-100$. Data show the average \pm SD of triplicate wells. ${ }^{*}, P<0.05$, Student's $t$ test. NS, not significant; RFU, relative fluorescence units; NI, uninfected. Data are presented for one representative experiment of five (A-C) and two (D) experiments with similar results. (TIF)

S10 Fig. IL-1 $\beta$ is not efficiently produced by $\mathrm{Casp} 1 / 11^{-/}$and $\mathrm{Asc} / \mathrm{Casp} 1 / 11^{-/}$macrophages. Bone marrow-derived macrophages (BMDMs) were generated from C57BL/6, Casp $1 / 11^{-1 /}$ and Asc/Casp $1 / 11^{-1-}$ mice and infected with wild-type L. pneumophila (WT Lp), motility-deficient mutants expressing flagellin $(f l i \Gamma)$ or with flagellin-deficient mutants $\left(\right.$ fla $\left.^{-}\right)$at a MOI of 10. The production of IL-1 $(\mathrm{A})$ and IL-12p40 (B) in the tissue culture supernatants was estimated by ELISA at 24 hours after infection. Data show the average \pm SD of triplicate wells. ${ }^{*}, P<0.05$, Student's t test. nd, not detected; RFU, relative fluorescence units; NI, uninfected. Data are presented for one representative experiment of two experiments with similar results. (TIF)

S11 Fig. Gasdermin-D is important for pore formation in C57BL/6 but not in Casp1/11 ${ }^{-1-}$ macrophages. BMDMs generated from C57BL/6 (A-D) and Casp $1 / 11^{-/-}(\mathrm{E}-\mathrm{H})$ mice were transduced with a retrovirus encoding shRNA sequence to target Gasdermin D (GSDMD) (Seq1) and a non-target shRNA sequence (NT). Transduced cells were infected with wild-type L. pneumophila (WT Lp) (B and F), motility-deficient mutants expressing flagellin (fli $)$ ) (C and $\mathrm{G}$ ) or with flagellin-deficient mutants $\left(\mathrm{flaA}^{-}\right)(\mathrm{D}$ and $\mathrm{H})$ at a MOI of 10. Pore formation was assessed fluorometrically in real time by the uptake of propidium iodide. The RFU (\%) represents the percentage of RFU compared with cells lysed with Triton X-100. Data show the average \pm SD of triplicate wells. RFU, relative fluorescence units; NI, uninfected. Data are presented for one representative experiment of two experiments with similar results.

(TIF) 


\section{Acknowledgments}

We are grateful to Maira Nakamura, Catarina Horta, Leticia Corsi and Victoria dos Santos for their technical assistance. We also thank Roberta Ribeiro Rosales for technical assistance in the institutional facility of the Multiphoton Microscopy. We thank Richard Flavell (Yale University) for providing the Casp $1 / 11^{-1-}$ mice and Vishva Dixit (Genentech) for providing the Casp $11^{-/}$and Casp $1^{-1-C a s p 11^{\text {tg }} \text { mice. }}$

\section{Author Contributions}

Conceptualization: Danielle P. A. Mascarenhas, Dario S. Zamboni.

Data curation: Danielle P. A. Mascarenhas.

Formal analysis: Danielle P. A. Mascarenhas, Daiane M. Cerqueira, Marcelo S. F. Pereira. Funding acquisition: Dario S. Zamboni.

Investigation: Danielle P. A. Mascarenhas, Daiane M. Cerqueira, Marcelo S. F. Pereira, Fernanda V. S. Castanheira, Talita D. Fernandes, Graziele Z. Manin, Larissa D. Cunha.

Methodology: Danielle P. A. Mascarenhas, Graziele Z. Manin, Larissa D. Cunha.

Project administration: Dario S. Zamboni.

Resources: Dario S. Zamboni.

Supervision: Dario S. Zamboni.

Validation: Danielle P. A. Mascarenhas, Daiane M. Cerqueira, Marcelo S. F. Pereira.

Visualization: Danielle P. A. Mascarenhas, Dario S. Zamboni.

Writing - original draft: Danielle P. A. Mascarenhas, Dario S. Zamboni.

Writing - review \& editing: Danielle P. A. Mascarenhas, Dario S. Zamboni.

\section{References}

1. Fraser DW, Tsai TR, Orenstein W, Parkin WE, Beecham HJ, et al. (1977) Legionnaires' disease: description of an epidemic of pneumonia. N Engl J Med 297: 1189-1197. https://doi.org/10.1056/ NEJM197712012972201 PMID: 335244

2. Horwitz MA (1983) The Legionnaires' disease bacterium (Legionella pneumophila) inhibits phagosomeIysosome fusion in human monocytes. J Exp Med 158: 2108-2126. PMID: 6644240

3. McDade JE, Shepard CC, Fraser DW, Tsai TR, Redus MA, et al. (1977) Legionnaires' disease: isolation of a bacterium and demonstration of its role in other respiratory disease. N Engl J Med 297: 11971203. https://doi.org/10.1056/NEJM197712012972202 PMID: 335245

4. Newton HJ, Ang DK, van Driel IR, Hartland EL (2010) Molecular pathogenesis of infections caused by Legionella pneumophila. Clin Microbiol Rev 23: 274-298. https://doi.org/10.1128/CMR.00052-09 PMID: 20375353

5. Khodr A, Kay E, Gomez-Valero L, Ginevra C, Doublet P, et al. (2016) Molecular epidemiology, phylogeny and evolution of Legionella. Infect Genet Evol 43: 108-122. https://doi.org/10.1016/j.meegid.2016. 04.033 PMID: 27180896

6. Berger KH, Isberg RR (1993) Two distinct defects in intracellular growth complemented by a single genetic locus in Legionella pneumophila. Mol Microbiol 7: 7-19. PMID: 8382332

7. Berger KH, Merriam JJ, Isberg RR (1994) Altered intracellular targeting properties associated with mutations in the Legionella pneumophila dotA gene. Mol Microbiol 14:809-822. PMID: 7891566

8. Isberg RR, O'Connor TJ, Heidtman M (2009) The Legionella pneumophila replication vacuole: making a cosy niche inside host cells. Nat Rev Microbiol 7: 13-24. https://doi.org/10.1038/nrmicro1967 PMID: 19011659 
9. Roy CR, Berger KH, Isberg RR (1998) Legionella pneumophila DotA protein is required for early phagosome trafficking decisions that occur within minutes of bacterial uptake. Mol Microbiol 28: 663-674. PMID: 9632267

10. Swanson MS, Hammer BK (2000) Legionella pneumophila pathogesesis: a fateful journey from amoebae to macrophages. Annu Rev Microbiol 54:567-613. https://doi.org/10.1146/annurev.micro.54.1. 567 PMID: 11018138

11. Yamamoto Y, Klein TW, Newton CA, Widen R, Friedman $H$ (1988) Growth of Legionella pneumophila in thioglycolate-elicited peritoneal macrophages from A/J mice. Infect Immun 56: 370-375. PMID: 3257460

12. Beckers MC, Yoshida S, Morgan K, Skamene E, Gros $P$ (1995) Natural resistance to infection with Legionella pneumophila: chromosomal localization of the Lgn1 susceptibility gene. Mamm Genome 6 : 540-545. PMID: 8589525

13. Dietrich WF, Damron DM, Isberg RR, Lander ES, Swanson MS (1995) Lgn1, a gene that determines susceptibility to Legionella pneumophila, maps to mouse chromosome 13. Genomics 26: 443-450. PMID: 7607666

14. Diez E, Yaraghi Z, MacKenzie A, Gros $P(2000)$ The neuronal apoptosis inhibitory protein (Naip) is expressed in macrophages and is modulated after phagocytosis and during intracellular infection with Legionella pneumophila. J Immunol 164: 1470-1477. PMID: 10640764

15. Diez E, Lee SH, Gauthier S, Yaraghi Z, Tremblay M, et al. (2003) Birc1e is the gene within the Lgn1 locus associated with resistance to Legionella pneumophila. Nat Genet 33: 55-60. https://doi.org/10. 1038/ng1065 PMID: 12483212

16. Wright EK, Goodart SA, Growney JD, Hadinoto V, Endrizzi MG, et al. (2003) Naip5 affects host susceptibility to the intracellular pathogen Legionella pneumophila. Curr Biol 13:27-36. PMID: 12526741

17. Amer A, Franchi L, Kanneganti TD, Body-Malapel M, Ozoren N, et al. (2006) Regulation of Legionella phagosome maturation and infection through flagellin and host Ipaf. J Biol Chem 281: 35217-35223. https://doi.org/10.1074/jbc.M604933200 PMID: 16984919

18. Molofsky AB, Byrne BG, Whitfield NN, Madigan CA, Fuse ET, et al. (2006) Cytosolic recognition of flagellin by mouse macrophages restricts Legionella pneumophila infection. J Exp Med 203: 1093-1104. https://doi.org/10.1084/jem.20051659 PMID: 16606669

19. Ren T, Zamboni DS, Roy CR, Dietrich WF, Vance RE (2006) Flagellin-deficient Legionella mutants evade caspase-1- and Naip5-mediated macrophage immunity. PLoS Pathog 2: e18. https://doi.org/10. 1371/journal.ppat.0020018 PMID: 16552444

20. Zamboni DS, Kobayashi KS, Kohlsdorf T, Ogura Y, Long EM, et al. (2006) The Birc1e cytosolic patternrecognition receptor contributes to the detection and control of Legionella pneumophila infection. Nat Immunol 7: 318-325. https://doi.org/10.1038/ni1305 PMID: 16444259

21. Case CL, Shin S, Roy CR (2009) Asc and Ipaf Inflammasomes direct distinct pathways for caspase-1 activation in response to Legionella pneumophila. Infect Immun 77: 1981-1991. https://doi.org/10. 1128/IAI.01382-08 PMID: 19237518

22. Lightfield KL, Persson J, Brubaker SW, Witte CE, von Moltke J, et al. (2008) Critical function for Naip5 in inflammasome activation by a conserved carboxy-terminal domain of flagellin. Nat Immunol 9: 11711178. https://doi.org/10.1038/ni.1646 PMID: 18724372

23. Miao EA, Leaf IA, Treuting PM, Mao DP, Dors M, et al. (2010) Caspase-1-induced pyroptosis is an innate immune effector mechanism against intracellular bacteria. Nat Immunol 11: 1136-1142. https:// doi.org/10.1038/ni.1960 PMID: 21057511

24. Silveira TN, Zamboni DS (2010) Pore formation triggered by Legionella spp. is an Nirc4 inflammasomedependent host cell response that precedes pyroptosis. Infect Immun 78: 1403-1413. https://doi.org/ 10.1128/IAI.00905-09 PMID: 20048047

25. Casson CN, Copenhaver AM, Zwack EE, Nguyen HT, Strowig T, et al. (2013) Caspase-11 activation in response to bacterial secretion systems that access the host cytosol. PLoS Pathog 9: e1003400. https://doi.org/10.1371/journal.ppat.1003400 PMID: 23762026

26. Jorgensen I, Lopez JP, Laufer SA, Miao EA (2016) IL-1beta, IL-18, and eicosanoids promote neutrophil recruitment to pore-induced intracellular traps following pyroptosis. Eur $\mathrm{J}$ Immunol.

27. LaRock CN, Cookson BT (2013) Burning down the house: cellular actions during pyroptosis. PLoS Pathog 9: e1003793. https://doi.org/10.1371/journal.ppat.1003793 PMID: 24367258

28. Mascarenhas DP, Pereira MS, Manin GZ, Hori JI, Zamboni DS (2015) Interleukin 1 receptor-driven neutrophil recruitment accounts to MyD88-dependent pulmonary clearance of legionella pneumophila infection in vivo. J Infect Dis 211: 322-330. https://doi.org/10.1093/infdis/jiu430 PMID: 25104770 
29. Pereira MS, Marques GG, Dellama JE, Zamboni DS (2011) The Nlrc4 Inflammasome Contributes to Restriction of Pulmonary Infection by Flagellated Legionella spp. that Trigger Pyroptosis. Front Microbiol 2: 33. https://doi.org/10.3389/fmicb.2011.00033 PMID: 21687424

30. Case CL, Roy CR (2011) Asc modulates the function of NLRC4 in response to infection of macrophages by Legionella pneumophila. MBio 2.

31. Hornung V, Ablasser A, Charrel-Dennis M, Bauernfeind F, Horvath G, et al. (2009) AIM2 recognizes cytosolic dsDNA and forms a caspase-1-activating inflammasome with ASC. Nature 458: 514-518. https://doi.org/10.1038/nature07725 PMID: 19158675

32. Man SM, Tourlomousis P, Hopkins L, Monie TP, Fitzgerald KA, et al. (2013) Salmonella infection induces recruitment of Caspase- 8 to the inflammasome to modulate IL-1beta production. $\mathrm{J}$ Immunol 191: 5239-5246. https://doi.org/10.4049/jimmunol.1301581 PMID: 24123685

33. Pierini R, Juruj C, Perret M, Jones CL, Mangeot P, et al. (2012) AIM2/ASC triggers caspase-8-dependent apoptosis in Francisella-infected caspase-1-deficient macrophages. Cell Death Differ 19: 17091721. https://doi.org/10.1038/cdd.2012.51 PMID: 22555457

34. Sagulenko V, Thygesen SJ, Sester DP, Idris A, Cridland JA, et al. (2013) AIM2 and NLRP3 inflammasomes activate both apoptotic and pyroptotic death pathways via ASC. Cell Death Differ 20: 11491160. https://doi.org/10.1038/cdd.2013.37 PMID: 23645208

35. Cerqueira DM, Pereira MS, Silva AL, Cunha LD, Zamboni DS (2015) Caspase-1 but Not Caspase-11 Is Required for NLRC4-Mediated Pyroptosis and Restriction of Infection by Flagellated Legionella Species in Mouse Macrophages and In Vivo. J Immunol 195: 2303-2311. https://doi.org/10.4049/jimmunol. 1501223 PMID: 26232428

36. Abdelaziz DH, Gavrilin MA, Akhter A, Caution K, Kotrange S, et al. (2011) Apoptosis-associated specklike protein (ASC) controls Legionella pneumophila infection in human monocytes. J Biol Chem 286 3203-3208. https://doi.org/10.1074/jbc.M110.197681 PMID: 21097506

37. Abdelaziz DH, Gavrilin MA, Akhter A, Caution K, Kotrange S, et al. (2011) Asc-dependent and independent mechanisms contribute to restriction of legionella pneumophila infection in murine macrophages. Front Microbiol 2: 18. https://doi.org/10.3389/fmicb.2011.00018 PMID: 21713115

38. Pereira MS, Morgantetti GF, Massis LM, Horta CV, Hori Jl, et al. (2011) Activation of NLRC4 by flagellated bacteria triggers caspase-1-dependent and -independent responses to restrict Legionella pneumophila replication in macrophages and in vivo. J Immunol 187: 6447-6455. https://doi.org/10.4049/ jimmunol.1003784 PMID: 22079982

39. Merriam JJ, Mathur R, Maxfield-Boumil R, Isberg RR (1997) Analysis of the Legionella pneumophila fli gene: intracellular growth of a defined mutant defective for flagellum biosynthesis. Infect Immun 65: 2497-2501. PMID: 9169800

40. Franchi L, Amer A, Body-Malapel M, Kanneganti TD, Ozoren N, et al. (2006) Cytosolic flagellin requires Ipaf for activation of caspase-1 and interleukin 1 beta in salmonella-infected macrophages. Nat Immunol 7: 576-582. https://doi.org/10.1038/ni1346 PMID: 16648852

41. Stutz A, Horvath GL, Monks BG, Latz E (2013) ASC speck formation as a readout for inflammasome activation. Methods Mol Biol 1040: 91-101. https://doi.org/10.1007/978-1-62703-523-1_8 PMID: 23852599

42. Masumoto J, Taniguchi S, Ayukawa K, Sarvotham H, Kishino T, et al. (1999) ASC, a novel 22-kDa protein, aggregates during apoptosis of human promyelocytic leukemia HL-60 cells. J Biol Chem 274: 33835-33838. PMID: 10567338

43. Fernandes-Alnemri T, Wu J, Yu JW, Datta P, Miller B, et al. (2007) The pyroptosome: a supramolecular assembly of ASC dimers mediating inflammatory cell death via caspase-1 activation. Cell Death Differ 14: 1590-1604. https://doi.org/10.1038/sj.cdd.4402194 PMID: 17599095

44. Hasegawa M, Imamura R, Kinoshita T, Matsumoto N, Masumoto J, et al. (2005) ASC-mediated NFkappaB activation leading to interleukin- 8 production requires caspase- 8 and is inhibited by CLARP. $J$ Biol Chem 280: 15122-15130. https://doi.org/10.1074/jbc.M412284200 PMID: 15701651

45. Broz P, von Moltke J, Jones JW, Vance RE, Monack DM (2010) Differential requirement for Caspase-1 autoproteolysis in pathogen-induced cell death and cytokine processing. Cell Host Microbe 8: 471483. https://doi.org/10.1016/j.chom.2010.11.007 PMID: 21147462

46. Vajjhala PR, Lu A, Brown DL, Pang SW, Sagulenko V, et al. (2015) The Inflammasome Adaptor ASC Induces Procaspase-8 Death Effector Domain Filaments. J Biol Chem 290: 29217-29230. https://doi. org/10.1074/jbc.M115.687731 PMID: 26468282

47. Masumoto J, Dowds TA, Schaner P, Chen FF, Ogura Y, et al. (2003) ASC is an activating adaptor for NF-kappa B and caspase-8-dependent apoptosis. Biochem Biophys Res Commun 303: 69-73. PMID 12646168 
48. Akhter A, Gavrilin MA, Frantz L, Washington S, Ditty C, et al. (2009) Caspase-7 activation by the Nlrc4/ Ipaf inflammasome restricts Legionella pneumophila infection. PLoS Pathog 5: e1000361. https://doi. org/10.1371/journal.ppat.1000361 PMID: 19343209

49. Man SM, Hopkins LJ, Nugent E, Cox S, Gluck IM, et al. (2014) Inflammasome activation causes dual recruitment of NLRC4 and NLRP3 to the same macromolecular complex. Proc Natl Acad Sci U S A 111: 7403-7408. https://doi.org/10.1073/pnas.1402911111 PMID: 24803432

50. Motani K, Kushiyama H, Imamura R, Kinoshita T, Nishiuchi T, et al. (2011) Caspase-1 protein induces apoptosis-associated speck-like protein containing a caspase recruitment domain (ASC)-mediated necrosis independently of its catalytic activity. J Biol Chem 286: 33963-33972. https://doi.org/10.1074/ jbc.M111.286823 PMID: 21832064

51. Kumar $Y$, Radha V, Swarup G (2010) Interaction with Sug1 enables I paf ubiquitination leading to caspase 8 activation and cell death. Biochem J 427: 91-104. https://doi.org/10.1042/BJ20091349 PMID: 20085538

52. Muruve DA, Petrilli V, Zaiss AK, White LR, Clark SA, et al. (2008) The inflammasome recognizes cytosolic microbial and host DNA and triggers an innate immune response. Nature 452: 103-107. https:// doi.org/10.1038/nature06664 PMID: 18288107

53. Roberts TL, Idris A, Dunn JA, Kelly GM, Burnton CM, et al. (2009) HIN-200 proteins regulate caspase activation in response to foreign cytoplasmic DNA. Science 323: 1057-1060. https://doi.org/10.1126/ science.1169841 PMID: 19131592

54. Burckstummer T, Baumann C, BlumI S, Dixit E, Durnberger G, et al. (2009) An orthogonal proteomicgenomic screen identifies AIM2 as a cytoplasmic DNA sensor for the inflammasome. Nat Immunol 10: 266-272. https://doi.org/10.1038/ni.1702 PMID: 19158679

55. Fernandes-Alnemri T, Yu JW, Datta P, Wu J, Alnemri ES (2009) AIM2 activates the inflammasome and cell death in response to cytoplasmic DNA. Nature 458:509-513. https://doi.org/10.1038/nature07710 PMID: 19158676

56. Aachoui Y, Leaf IA, Hagar JA, Fontana MF, Campos CG, et al. (2013) Caspase-11 protects against bacteria that escape the vacuole. Science 339: 975-978. https://doi.org/10.1126/science.1230751 PMID: 23348507

57. Ge J, Gong YN, Xu Y, Shao F (2012) Preventing bacterial DNA release and absent in melanoma 2 inflammasome activation by a Legionella effector functioning in membrane trafficking. Proc Natl Acad Sci U S A 109: 6193-6198. https://doi.org/10.1073/pnas.1117490109 PMID: 22474394

58. Pierini R, Perret M, Djebali S, Juruj C, Michallet MC, et al. (2013) ASC controls IFN-gamma levels in an IL-18-dependent manner in caspase-1-deficient mice infected with Francisella novicida. J Immunol 191: 3847-3857. https://doi.org/10.4049/jimmunol.1203326 PMID: 23975862

59. Kaiser WJ, Upton JW, Long AB, Livingston-Rosanoff D, Daley-Bauer LP, et al. (2011) RIP3 mediates the embryonic lethality of caspase-8-deficient mice. Nature 471: 368-372. https://doi.org/10.1038/ nature09857 PMID: 21368762

60. Varfolomeev EE, Schuchmann M, Luria V, Chiannilkulchai N, Beckmann JS, et al. (1998) Targeted disruption of the mouse Caspase 8 gene ablates cell death induction by the TNF receptors, Fas/Apo1, and DR3 and is lethal prenatally. Immunity 9: 267-276. PMID: 9729047

61. Case CL, Kohler LJ, Lima JB, Strowig T, de Zoete MR, et al. (2013) Caspase-11 stimulates rapid flagellin-independent pyroptosis in response to Legionella pneumophila. Proc Natl Acad Sci U S A 110: 1851-1856. https://doi.org/10.1073/pnas.1211521110 PMID: 23307811

62. Fink SL, Cookson BT (2006) Caspase-1-dependent pore formation during pyroptosis leads to osmotic lysis of infected host macrophages. Cell Microbiol 8: 1812-1825. https://doi.org/10.1111/j.1462-5822. 2006.00751.x PMID: 16824040

63. Talanian RV, Quinlan C, Trautz S, Hackett MC, Mankovich JA, et al. (1997) Substrate specificities of caspase family proteases. J Biol Chem 272: 9677-9682. PMID: 9092497

64. Thornberry NA, Rano TA, Peterson EP, Rasper DM, Timkey T, et al. (1997) A combinatorial approach defines specificities of members of the caspase family and granzyme B. Functional relationships established for key mediators of apoptosis. J Biol Chem 272: 17907-17911. PMID: 9218414

65. Garcia-Calvo M, Peterson EP, Leiting B, Ruel R, Nicholson DW, et al. (1998) Inhibition of human caspases by peptide-based and macromolecular inhibitors. J Biol Chem 273: 32608-32613. PMID: 9829999

66. Kayagaki N, Warming S, Lamkanfi M, Vande Walle L, Louie S, et al. (2011) Non-canonical inflammasome activation targets caspase-11. Nature 479: 117-121. https://doi.org/10.1038/nature10558 PMID: 22002608 
67. Kayagaki N, Stowe IB, Lee BL, O'Rourke K, Anderson K, et al. (2015) Caspase-11 cleaves gasdermin D for non-canonical inflammasome signalling. Nature 526: 666-671. https://doi.org/10.1038/ nature15541 PMID: 26375259

68. Shi J, Zhao Y, Wang K, Shi X, Wang Y, et al. (2015) Cleavage of GSDMD by inflammatory caspases determines pyroptotic cell death. Nature 526:660-665. https://doi.org/10.1038/nature15514 PMID: 26375003

69. Kofoed EM, Vance RE (2011) Innate immune recognition of bacterial ligands by NAIPs determines inflammasome specificity. Nature 477: 592-595. https://doi.org/10.1038/nature10394 PMID: 21874021

70. Zhao Y, Yang J, Shi J, Gong YN, Lu Q, et al. (2011) The NLRC4 inflammasome receptors for bacterial flagellin and type III secretion apparatus. Nature 477: 596-600. https://doi.org/10.1038/nature10510 PMID: 21918512

71. Coers J, Vance RE, Fontana MF, Dietrich WF (2007) Restriction of Legionella pneumophila growth in macrophages requires the concerted action of cytokine and Naip5/Ipaf signalling pathways. Cell Microbiol 9: 2344-2357. https://doi.org/10.1111/j.1462-5822.2007.00963.x PMID: 17506816

72. Fortier A, Doiron K, Saleh M, Grinstein S, Gros P (2009) Restriction of Legionella pneumophila replication in macrophages requires concerted action of the transcriptional regulators IIf1 and Irf8 and nod-like receptors Naip5 and Nirc4. Infect Immun 77: 4794-4805. https://doi.org/10.1128/IAI.01546-08 PMID: 19720760

73. Rauch I, Deets KA, Ji DX, von Moltke J, Tenthorey JL, et al. (2017) NAIP-NLRC4 Inflammasomes Coordinate Intestinal Epithelial Cell Expulsion with Eicosanoid and IL-18 Release via Activation of Caspase1 and -8. Immunity 46: 649-659. https://doi.org/10.1016/j.immuni.2017.03.016 PMID: 28410991

74. Rogers C, Fernandes-Alnemri T, Mayes L, Alnemri D, Cingolani G, et al. (2017) Cleavage of DFNA5 by caspase-3 during apoptosis mediates progression to secondary necrotic/pyroptotic cell death. Nat Commun 8: 14128. https://doi.org/10.1038/ncomms14128 PMID: 28045099

75. Wang Y, Gao W, Shi X, Ding J, Liu W, et al. (2017) Chemotherapy drugs induce pyroptosis through caspase- 3 cleavage of a Gasdermin. Nature.

76. Feeley JC, Gibson RJ, Gorman GW, Langford NC, Rasheed JK, et al. (1979) Charcoal-yeast extract agar: primary isolation medium for Legionella pneumophila. J Clin Microbiol 10: 437-441. PMID: 393713

77. Marim FM, Silveira TN, Lima DS Jr., Zamboni DS (2010) A method for generation of bone marrowderived macrophages from cryopreserved mouse bone marrow cells. PLoS One 5: e15263. https://doi. org/10.1371/journal.pone.0015263 PMID: 21179419

78. Milstein S, Nguyen M, Meyers R, de Fougerolles A (2013) Measuring RNAi knockdown using qPCR Methods Enzymol 533: 57-77. https://doi.org/10.1016/B978-0-12-420067-8.00006-4 PMID: 24182918

79. Lara-Tejero M, Sutterwala FS, Ogura Y, Grant EP, Bertin J, et al. (2006) Role of the caspase-1 inflammasome in Salmonella typhimurium pathogenesis. J Exp Med 203: 1407-1412. https://doi.org/10. 1084/jem.20060206 PMID: 16717117

80. Kuida K, Lippke JA, Ku G, Harding MW, Livingston DJ, et al. (1995) Altered cytokine export and apoptosis in mice deficient in interleukin-1 beta converting enzyme. Science 267: 2000-2003. PMID: 7535475

81. Sutterwala FS, Ogura Y, Szczepanik M, Lara-Tejero M, Lichtenberger GS, et al. (2006) Critical role for NALP3/CIAS1/Cryopyrin in innate and adaptive immunity through its regulation of caspase-1. Immunity 24: 317-327. https://doi.org/10.1016/j.immuni.2006.02.004 PMID: 16546100 
Supplementary Fig.1 Mascarenhas et al.

๑ C57BL/6

- NIrc4 $4^{-1}$

- Casp1/11\%

$\nabla \mathrm{Asc}^{-1}$
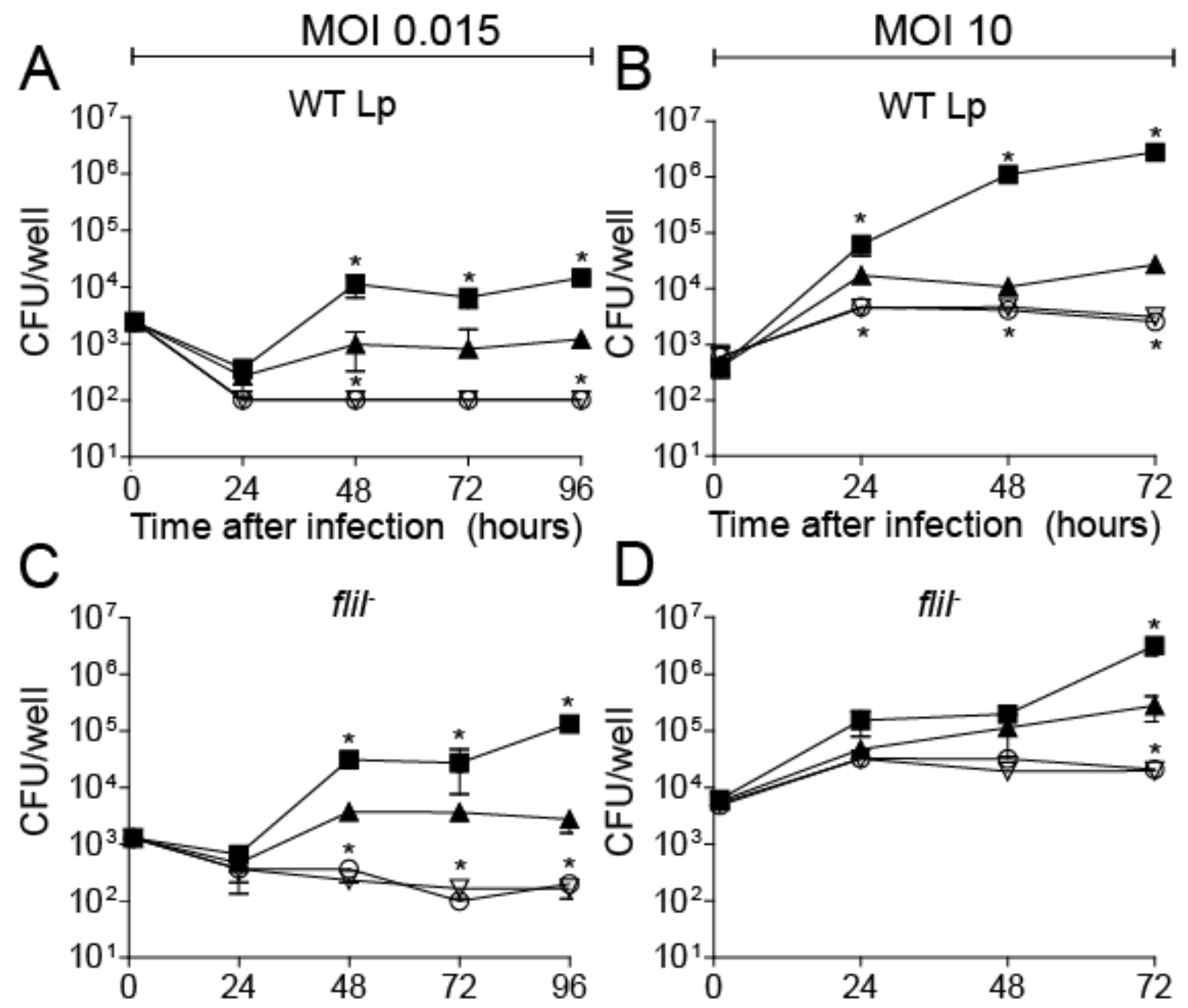

- Time after infection (hours)
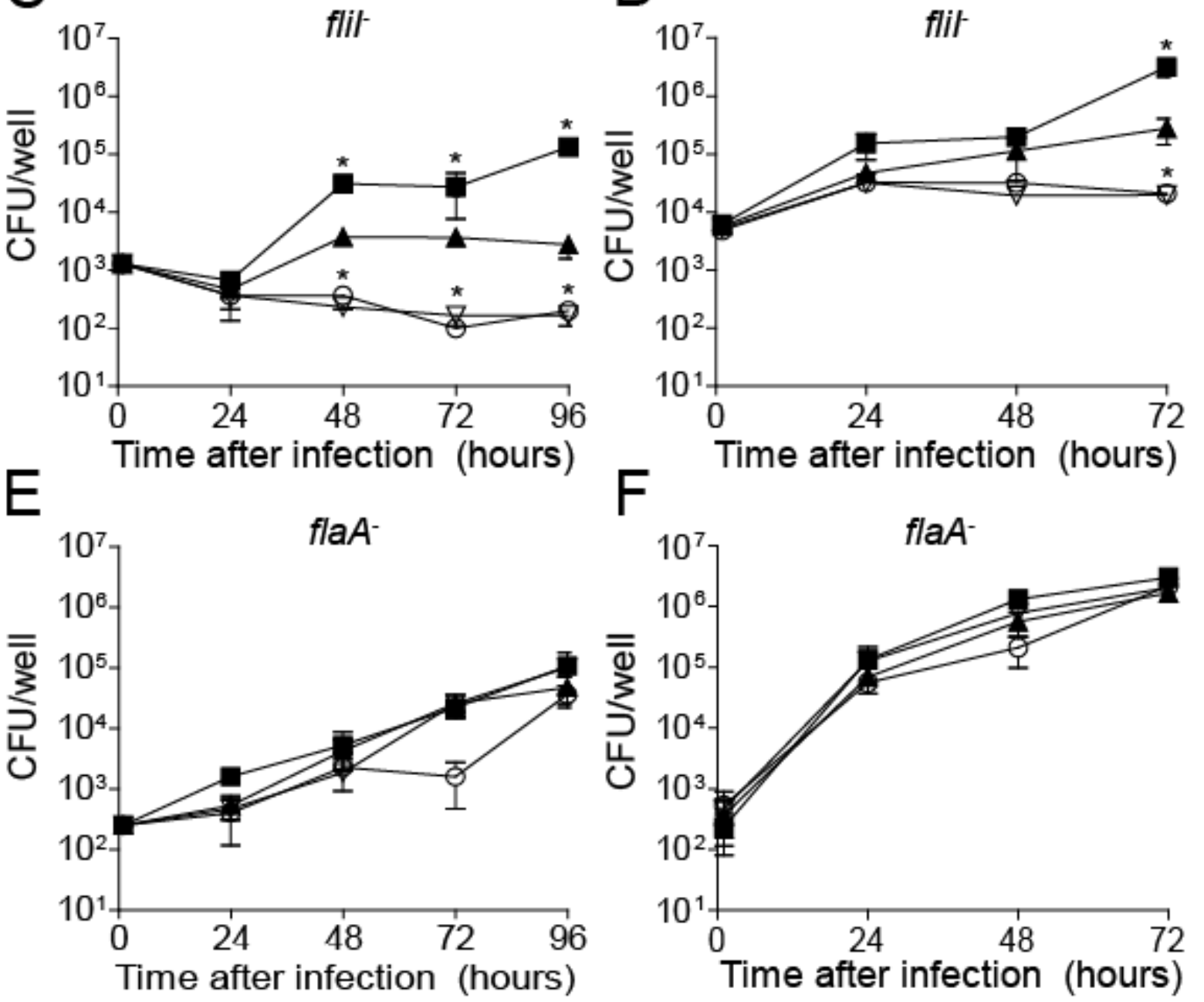
Supplementary Fig.2. Mascarenhas et al.
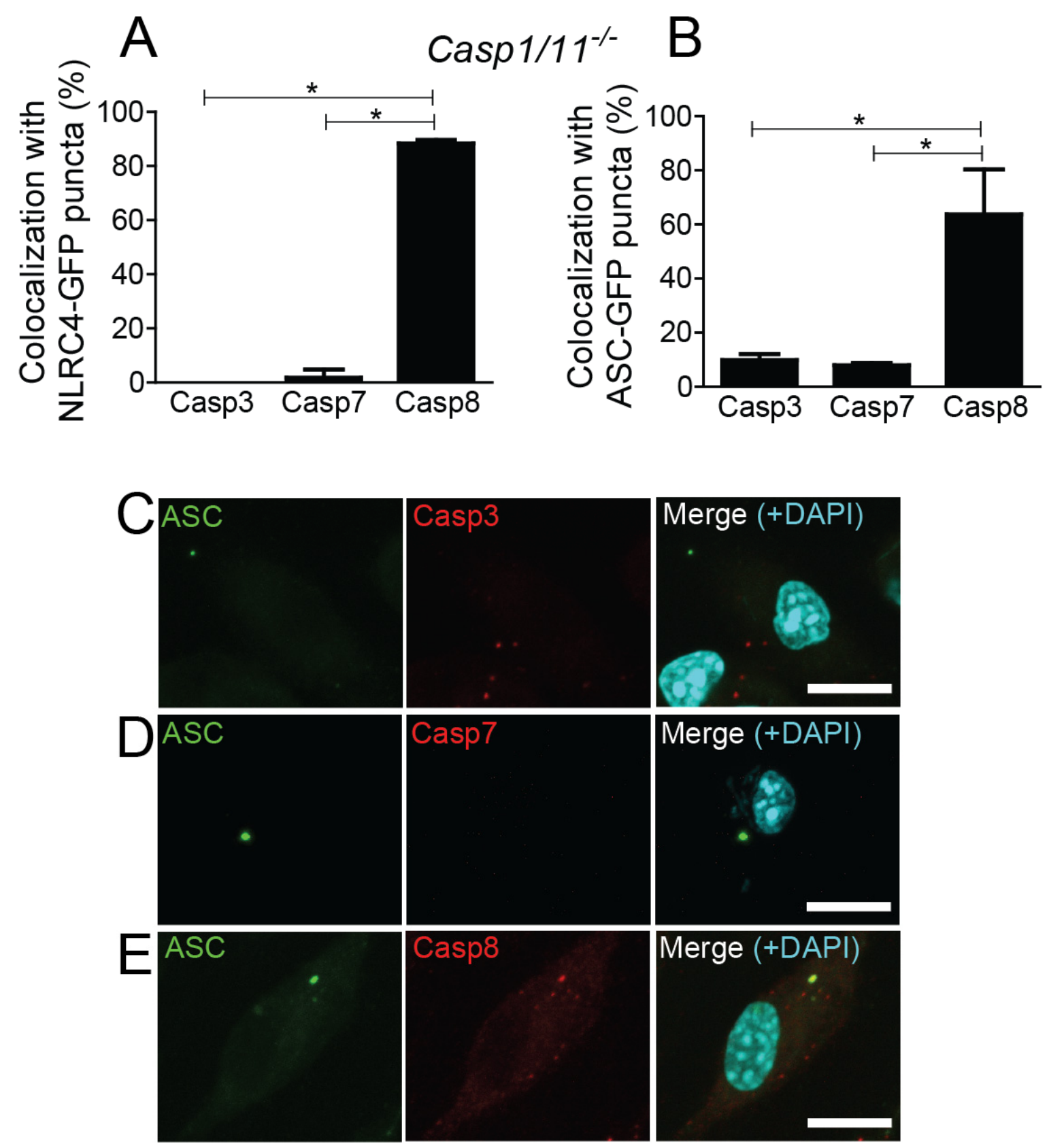
Supplementary Fig.3. Mascarenhas et al.

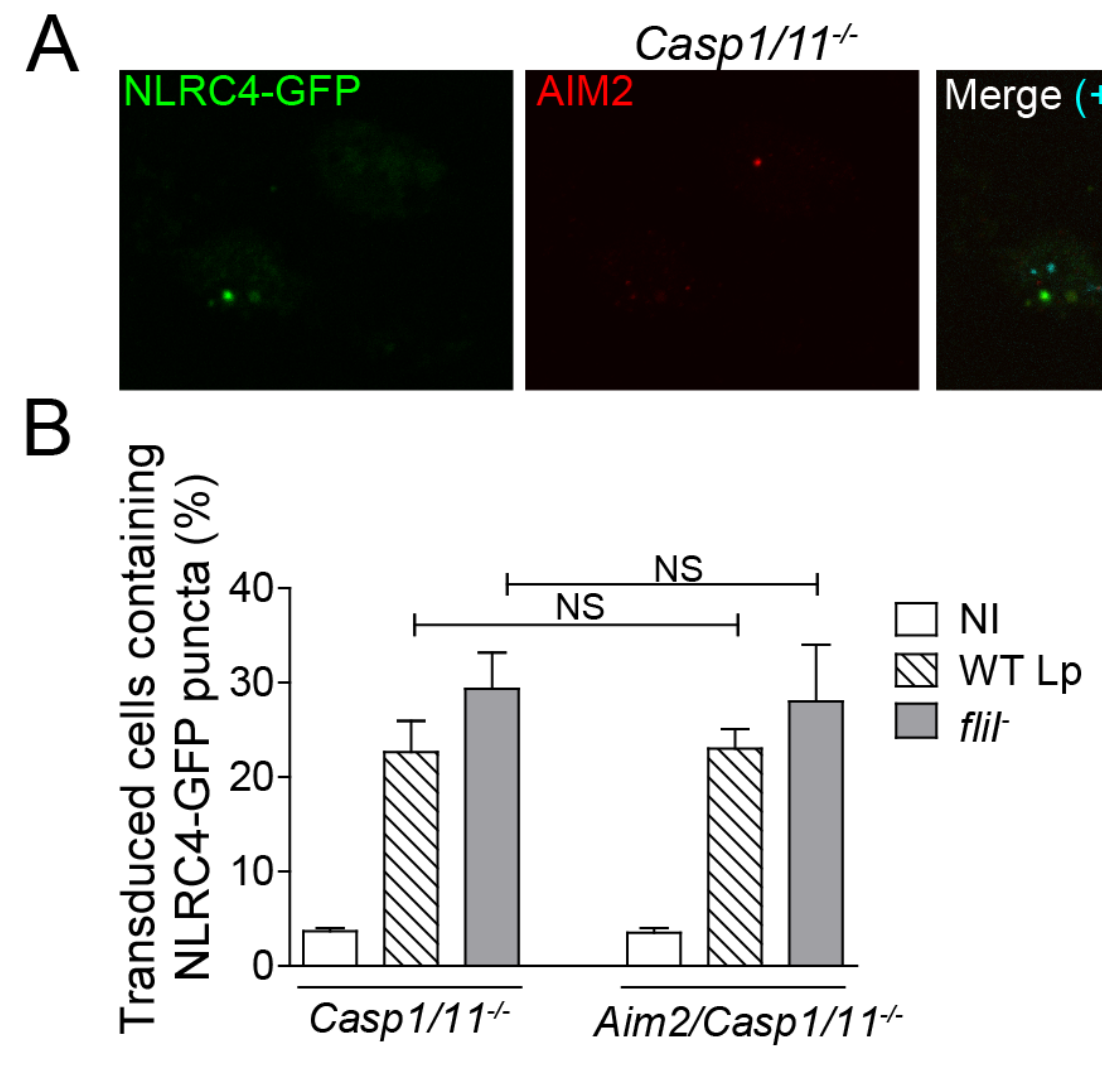

Supplementary Fig.4. Mascarenhas et al.

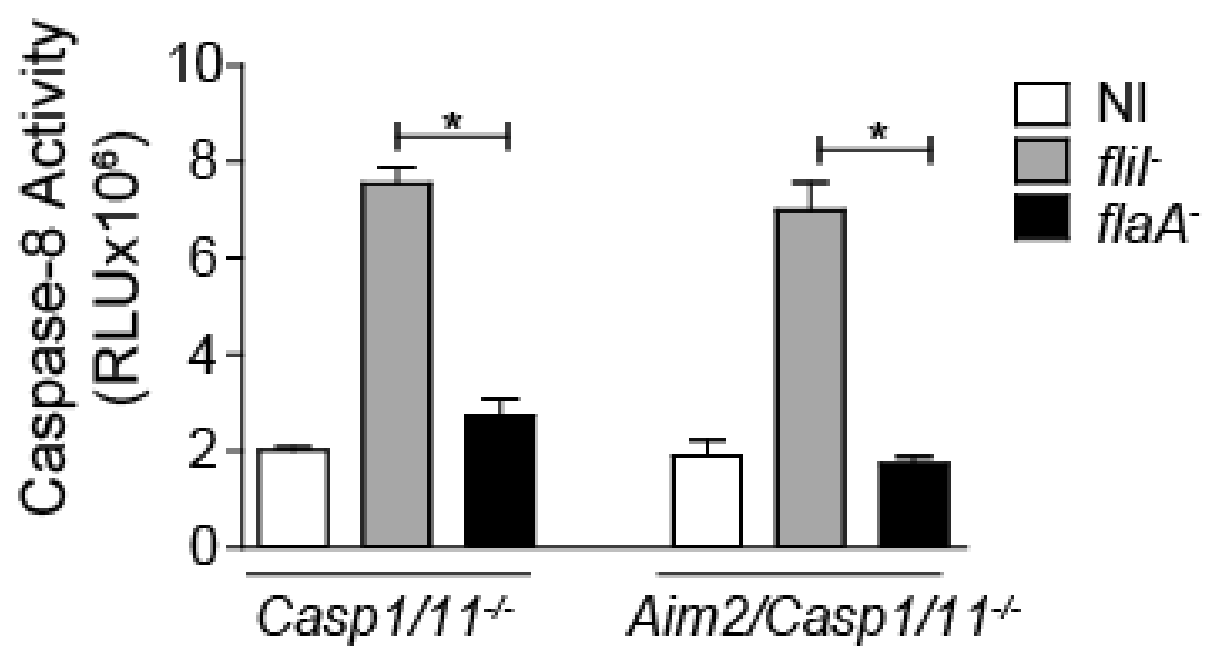


Supplementary Fig.5. Mascarenhas et al.

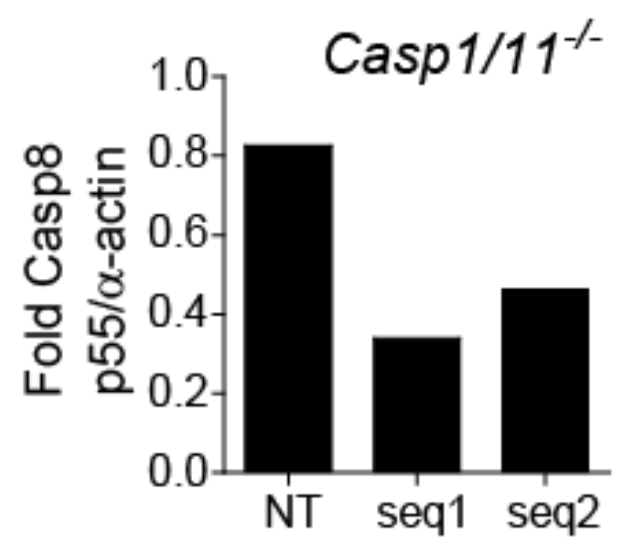

Supplementary Fig.6. Mascarenhas et al.

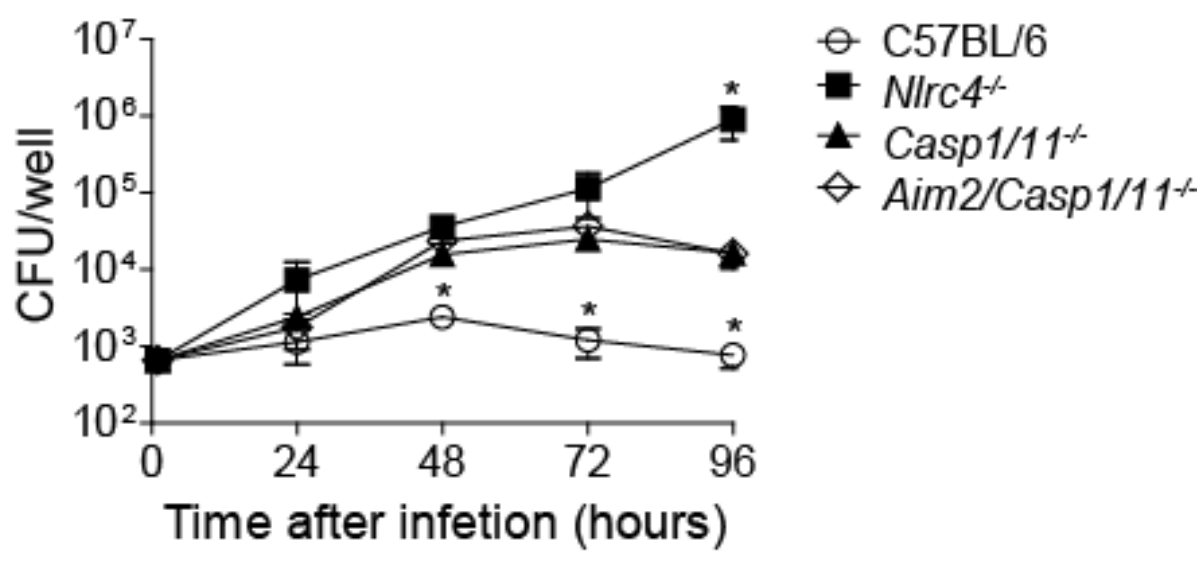

Supplementary Fig.7. Mascarenhas et al.

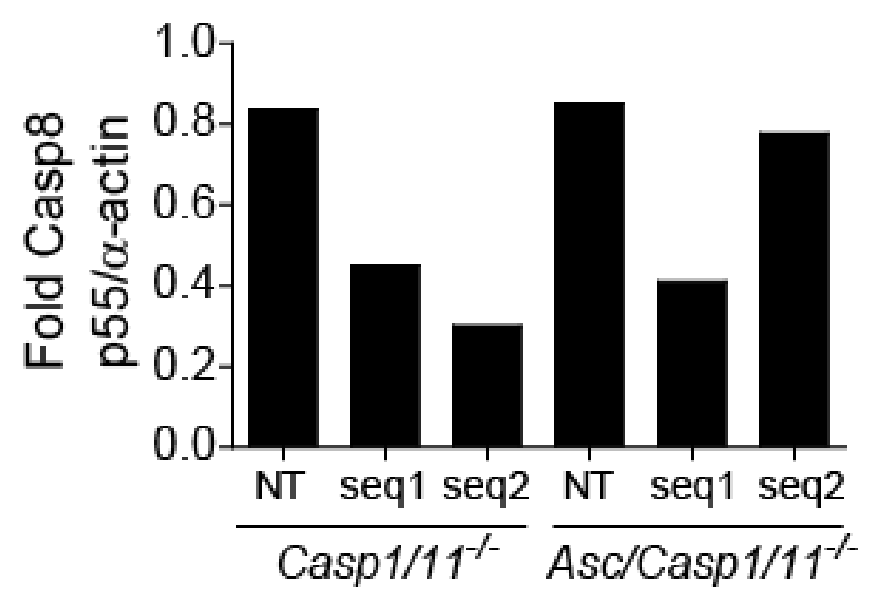


Supplementary Fig. 8. Mascarenhas et al.

A

flil $^{-}$

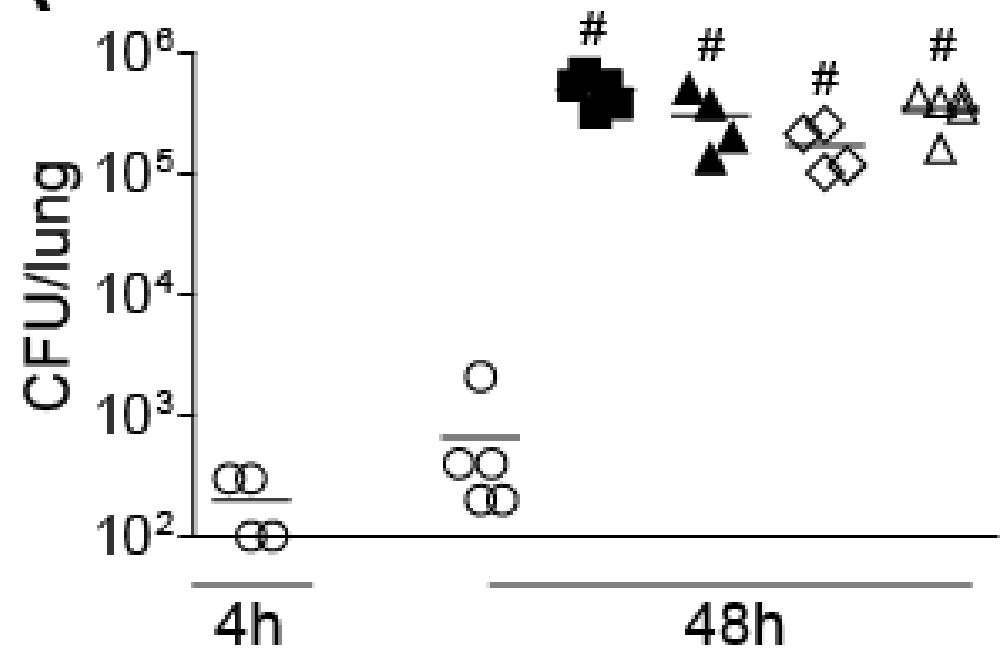

○ C57BL/6

- NIrc4 ${ }^{-1}$

A Casp1/11\%

$\diamond$ Aim2/Casp1/11

$\triangle$ Asc/Casp1/11-

B

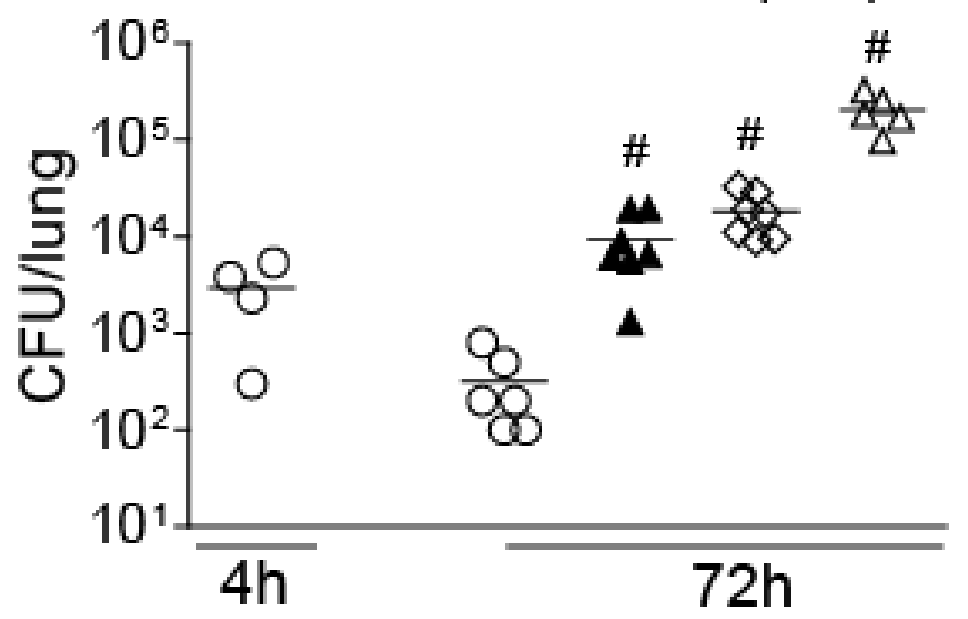

○ C57BL/6

- Casp1/11\%

$\diamond$ Aim2/Casp1/11-

$\triangle$ Asc/Casp1/11\% 
Supplementary Fig.9 Mascarenhas et al.
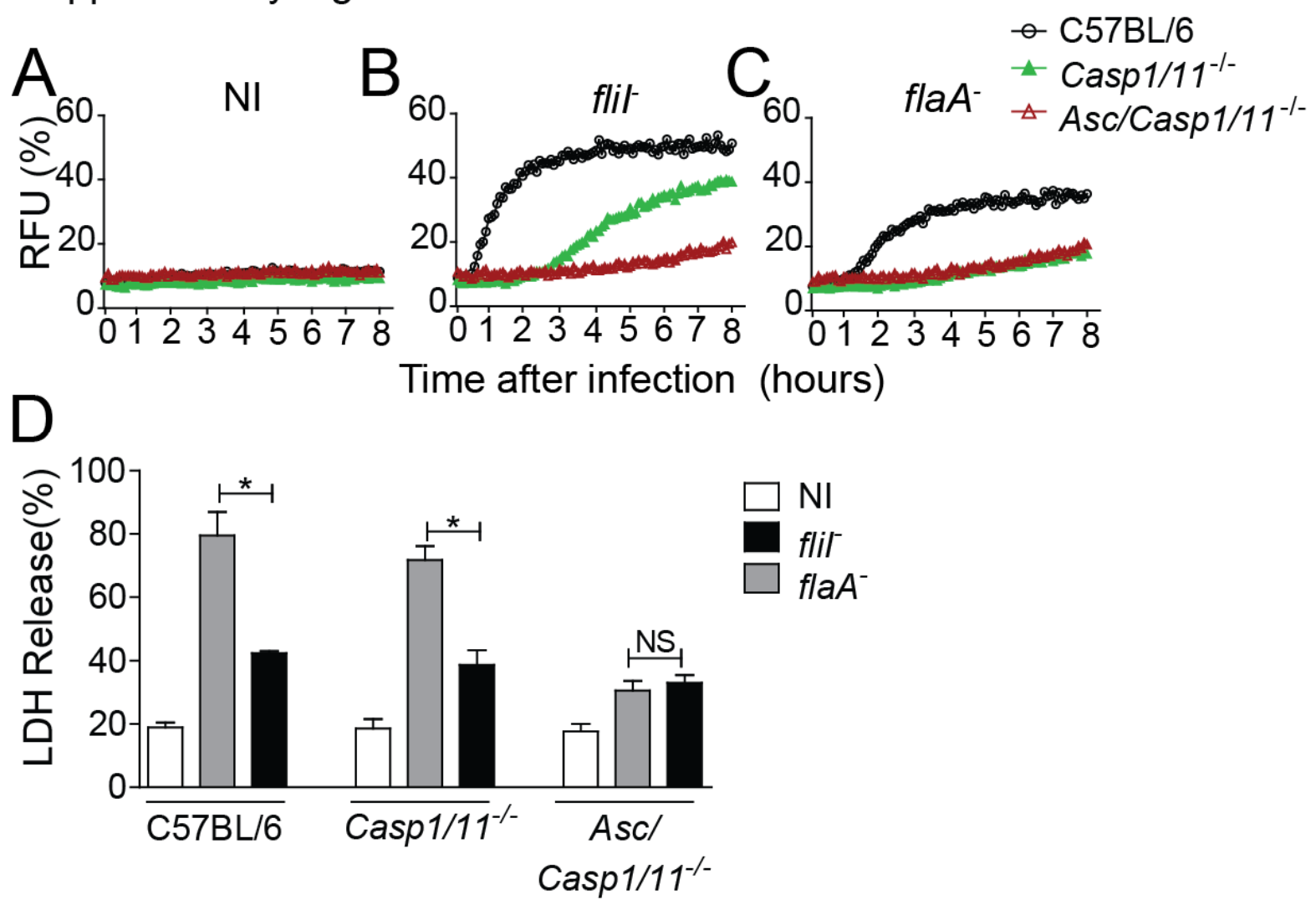

Supplementary Fig.10 Mascarenhas et al.

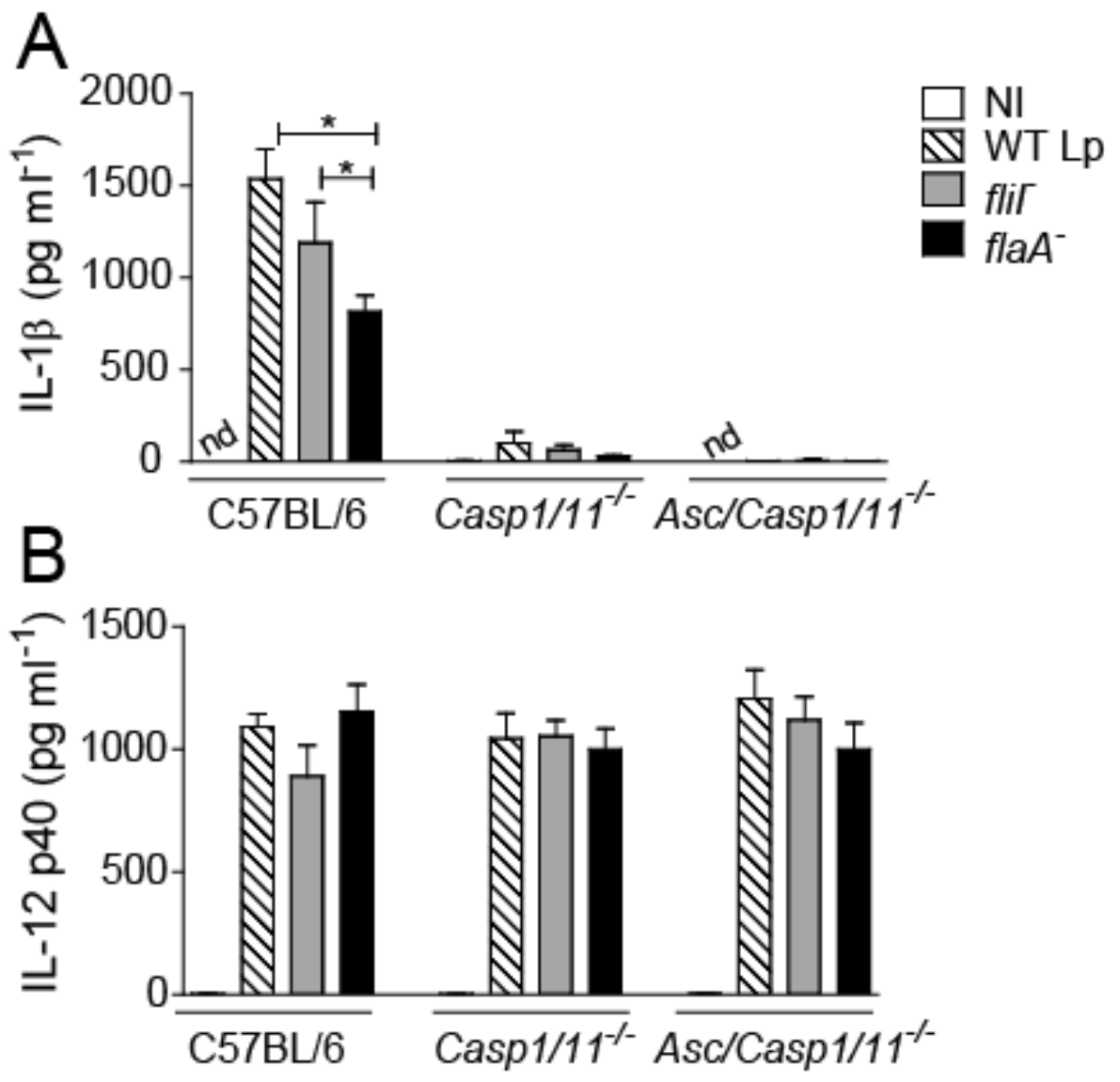


Supplementary Fig.11 Mascarenhas et al.

$\star$ NT ShRNA

$\because$ shRNA GSDMD Seq1

- shRNA GSDMD Seq2

C57BL/6

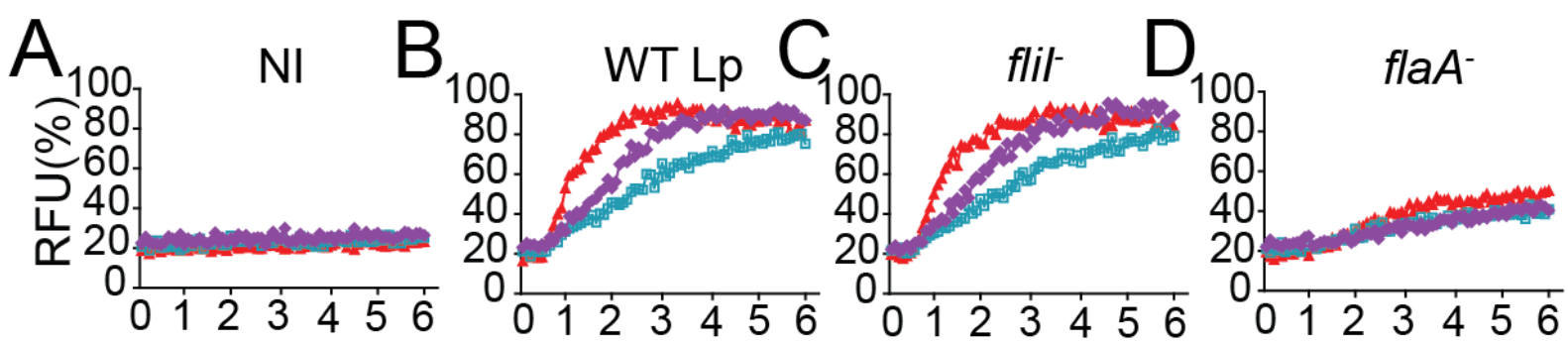

Casp1/11\%-

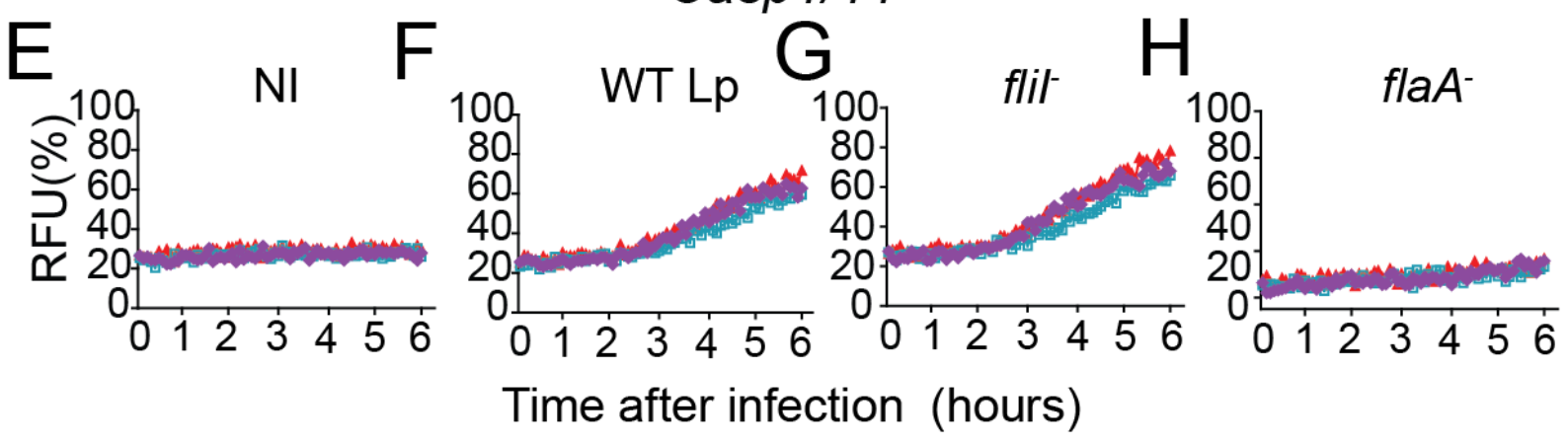

